Antichistica 30

Studi orientali 12

\title{
Headscarf and Veiling Glimpses from Sumer to Islam
}

edited by

Roswitha Del Fabbro, Frederick Mario Fales, Hannes D. Galter

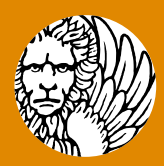

\section{Edizioni}

Ca'Foscari 
Headscarf and Veiling

\section{Antichistica Studi orientali}

Collana diretta da

Lucio Milano

$30 \mid 12$

Edizioni

Ca'Foscari 


\section{Antichistica \\ Studi orientali}

\section{Direttore scientifico}

Lucio Milano (Università Ca' Foscari Venezia, Italia)

\section{Comitato scientifico}

Claudia Antonetti (Università Ca' Foscari Venezia, Italia)

Filippo Maria Carinci (Università Ca' Foscari Venezia, Italia)

Ettore Cingano (Università Ca' Foscari Venezia, Italia)

Joy Connolly (New York University, USA)

Andrea Giardina (Scuola Normale Superiore, Pisa, Italia)

Marc van de Mieroop (Columbia University in the City of New York, USA)

Elena Rova (Università Ca' Foscari Venezia, Italia)

Fausto Zevi (Sapienza Università di Roma, Italia)

\section{Direzione e redazione}

Dipartimento di Studi Umanistici

Università Ca' Foscari Venezia

Palazzo Malcanton Marcorà

Dorsoduro 3484/D

30123 Venezia

Antichistica | Studi orientali

e-ISSN 2610-9336

ISSN 2610-881X

URL http://edizionicafoscari.unive.it/it/edizioni/collane/antichistica/ 


\section{Headscarf and Veiling Glimpses from Sumer to Islam}

edited by

Roswitha del Fabbro, Frederick Mario Fales, Hannes D. Galter

Venezia

Edizioni Ca' Foscari - Digital Publishing 2021 
Headscarf and Veiling. Glimpses from Sumer to Islam

edited by Roswitha Del Fabbro, Frederick Mario Fales, Hannes G. Galter

(c) 2021 Roswitha Del Fabbro, Frederick Mario Fales, Hannes G. Galter for the text | peril testo (C) 2021 Edizioni Ca' Foscari - Digital Publishing for the present edition | per la presente edizione

\section{(c) (i)}

This work is licensed under a Creative Commons Attribution 4.0 International License Quest'opera è distribuita con Licenza Creative Commons Attribuzione 4.0 Internazionale

copenss

Any part of this publication may be reproduced, stored in a retrieval system, or transmitted in any form or by any means without permission provided that the source is fully credited.

Qualunque parte di questa pubblicazione può essere riprodotta, memorizzata in un sistema di recupero dati o trasmessa in qualsiasi forma o con qualsiasi mezzo, elettronico o meccanico, senza autorizzazione, a condizione che se ne citi la fonte.

\section{$\mathcal{L}$}

Scientific certification of the works published by Edizioni Ca' Foscari - Digital Publishing: the essays published have received a favourable evaluation by subject-matter experts, through a double blind peer review process under the responsibility of the Scientific Committee of the series. The evaluations were conducted in adherence to the scientific and editorial criteria established by Edizioni Ca' Foscari. Certificazione scientifica delle Opere pubblicate da Edizioni Ca' Foscari - Digital Publishing: i saggi pubblicati hanno ottenuto il parere favorevole da parte di valutatori esperti della materia, attraverso un processo di revisione doppia anonima, sotto la responsabilità del Comitato scientifico della collana. La valutazione è stata condotta in aderenza ai criteri scientifici ed editoriali di Edizioni Ca’' Foscari.

Edizioni Ca' Foscari - Digital Publishing | Fondazione Università Ca' Foscari

Dorsoduro 3246, 30123 Venezia | http://edizionicafoscari.unive.it/ | ecf@unive.it

1st edition August 2021 | 1a edizione agosto 2021

ISBN 978-88-6969-521-6 [ebook]

ISBN 978-88-6969-522-3 [print]

This volume has been realised thanks to the contribution of the Autonomous Region Friuli Venezia Giulia (Public Notice of Manifestations for the Dissemination of Humanistic Culture -year 2020). The initiative is part of the second Festival of Public Archeology - No Borders promoted by the Cultural Association A.C. CulturArti.

The congress in March 2020 has been organised and carried out by the Institute of Classics at the University of Graz.
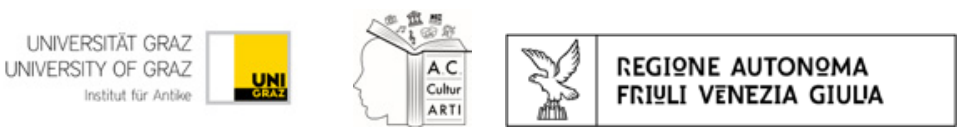

Headscarf and Veiling. Glimpses from Sumer to Islam / edited by Roswitha Del Fabbro, Frederick Mario Fales, Hannes G. Galter - 1. ed. - Venezia: Edizioni Ca' Foscari - Digital Publishing, 2021. - 206 p.; 16 cm. - (Antichistica; 30, 12). - ISBN 978-88-6969-522-3. 


\author{
Headscarf and Veiling \\ Glimpses from Sumer to Islam \\ edited by Roswitha Del Fabbro, Frederick Mario Fales, Hannes G. Galter
}

\title{
Abstract
}

This volume represents a small, but specifically targeted contribution to a field of research and discussion which has increasingly come to the fore in the last two decades, regarding the practice of covering or veiling womens' heads or faces over different times and places. "Dress is never value free", as anthropologists state, and veiling functions as an assertion/communication of relationship dynamics in terms of gender, of social and cultural identity, of the phases and stages of life (puberty, marriage, death) or of religious beliefs - even reaching to a typical dichotomy of our times, the female condition between tradition and modernity.

This book stems from an international conference at the University of Graz on March 2, 2020 - just before the outbreak of the COVID pandemic. The conference brought together Austrian specialists from the Graz Department of Ancient History and Classical Studies and from the URANIA für Steiermark Association, with academics from different Italian universities connected by the Cultural Association A.C. CulturArti of Udine within the framework of its second Alpe-Adria Festival of Public Archeology - No Borders project, funded by the Friuli Venezia Giulia Autonomous Region.

A felicitous meeting between specialists from Austria and Italy, under the aegis of a mixed public and private management, now finds its outcome in the present volume, jointly edited by academics and organisers from both countries, with all papers in English.

Keywords Sumer. Ancient Near East. Islam. Veiling. Head covering. Headscarf debate. Women. Qur'an. 



\section{Table of Contents}

Preface

Roswitha Del Fabbro

Foreword

Wolfgang Spickermann

Introduction

Hannes D. Galter

Veil and Headscarf: Five Aspects of a Cultural Phenomenon Hannes D. Galter

The Veil in Ancient Near Eastern Religions and Cultures

Some Remarks

Maria Giovanna Biga

Veiling in Ancient Near Eastern Legal Contexts

Frederick Mario Fales

To See or Not to See. The Issue of Visuality

in Ancient Near Eastern Art

Images of Queens, High Priestesses, and Other Elite Women in the 3rd Millennium BC

The Practice of Veiling as an Expression of the Moral Behaviour of Women and Their Social Status in the Qur'an Karl Prenner

The Bonnet and the Beret in Medieval and German

Renaissance Art 
On the Contemporary Debate About the Headscarf in Austria

Carla Amina Baghajati

The Headscarf as a Discursive Battlefield

Positions of the Current Discourse on Muslim Veiling in Austria and Germany

Gabriel Malli 


\section{Preface}

Roswitha Del Fabbro

President of A.C.CulturArti, Udine, Italia

Nowadays, the use of the female veil in the Islamic religious and cultural tradition is discussed in many different ways and perspectives, sometimes even going as far as studies of comparison with biblical Judaism and Pauline Christianity. Hardly at all debated, however, is the question of the possible antecedents of female veiling, for social or religious use, in the Near East (Assyria, Babylonia and the Levant) of the millennia preceding these three monotheistic traditions. Is it from the ancient Near East that the use of the burqa was born? Or did feminine veiling have different connotations, which were then modified with the progressive crisis of the polytheistic horizon? On 2 March 2020, a multilingual conference held at the Karl-FranzensUniversität in Graz (Austria) was devoted to the theme of the female veil from the ancient Orient to Islam, with a series of aimed interventions by historians, experts in law and religion, art historians, and other specialists on the ancient, medieval and modern Near East. The conference was organised by the Cultural Association CulturArti (A.C.CulturArti) of Udine (Italy) in collaboration with the KarlFranzens-Universität of Graz, as part of the comprehensive cultural project 2nd Alpe-Adria Festival of Public Archaeology. No Borders, for which the A.C.CulturArti was financed by the Friuli Venezia Giulia Autonomous Region (as outcome of the 2019-20 Public Notice of Manifestations of Dissemination of Humanistic Culture).

I am personally very grateful to Prof. Wolfgang Spickermann, of the University of Graz, who introduced the proceedings on the morning of 2 March; and to Prof. F. Mario Fales (University of Udine) and Prof. Hannes D. Galter (University of Graz), who not only planned 
and organised the entire scientific event at length beforehand, but then also concretely led the interesting and constructive multidisciplinary discussions which followed each paper, thus guaranteeing the success of the Conference to the general satisfaction of participants and audience.

The dire and long-lasting events in worldwide health, which immediately followed upon this felicitous Italo-Austrian academic gathering, can only cast a veil of longing for all international opportunities of this type, lost from that time onwards, but which hopefully we will return to enjoy as soon as possible.

I transcribe the full programme of the conference:

\section{Il velo femminile dall'Antico Oriente all'Islam | Kopftuch und Schleier von alten Orient bis zum Islam}

2 March 2020 | h. 9:00-17:00 Karl-Franzens-Universität Graz Sitzungszimmer 15.21, Universitätsstraße 15, A2, 8010 Graz/Austria

\section{PROGRAMME}

Monday, 02.03.2020

Chair: Johannes Gießauf

09.00 Opening: Roswitha Del Fabbro (A.C.CulturArti, Udine) / Wolfgang Spickermann (University of Graz); 09.15 Introduction: Mario Fales (University of Udine) / Hannes D. Galter (University of Graz); 09.30 Hannes D. Galter (University of Graz): Kopftuch und Schleier - Eine Kulturgeschichte; 10.00 Coffee break.

10.30 Giovanna Biga (Sapienza University of Rome): The Veil in Ancient Near Eastern Religion and Culture; 11.00 Mario Fales (University of Udine): Veiling in Ancient Near Eastern Legal Contexts; 11.30 Peter Mauritsch (University of Graz): Verhüllungen? Schleierhaftes in antiken Texten und Bildern; 12.00 Lunch break.

Chair: Hannes D. Galter

14.00 Karl Prenner (University of Graz): Verhüllung als Ausdruck des sittlichen Verhaltens der Frau und ihrer sozialen Stellung im Koran; 14.30 Carla Amina Baghajati (Schulamtsleiterin der IGGÖ, Vienna): Zur gegenwärtigen Kopftuchdebatte in Österreich; 15.00 Gabriel Malli (University of Graz/Erfurt): Der Schleier als diskursives Kampffeld. Bedeutungszuschreibungen an den Hijab im „Westen“; 15.30 Coffee break. 
16.00 Davide Nadali (Sapienza University of Rome): To See, or Not To See. The Issue of Visuality in Ancient Near Eastern Art; 16.30 Margit Stadlober (University of Graz): Haube und Barett in den Bildern des Mittelalters und der Renaissance.

This volume presents the proceedings of this conference. The organisers from A.C.CulturArti of Udine and Karl-Franzens-Universität of Graz are very grateful to Ca' Foscari University Press, in the person of the General Editor, Dr Massimiliano Vianello, and in particular to Prof. Lucio Milano (Chair of History of the Ancient Near East, Ca' Foscari University of Venice), for accepting the papers as an edited book in Edizioni Ca' Foscari's catalogue, which is marked by an agile and professional print edition and an open access digital edition in many areas of academic research. 



\section{Foreword}

Wolfgang Spickermann

Universität Graz, Österreich

The International Conference Il velo femminile dall'Antico Oriente all'Islam / Kopftuch und Schleier vom Alten Orient bis zum Islam was the last conference in this year 2020 dominated by COVID-19 that the Department of Ancient History and Classical Studies of the Institute of Classics at the University of Graz was able to hold in presence shortly before the final shutdown in spring. Under this good omen, the printed proceedings of the conference are now available, for which I would like to thank the editors. With its wide range of topics, it documents not only the international cooperation of our department with the A.C.CulturArti in Udine and the Urania in Graz over several years, but also an interdisciplinary cooperation of various disciplines in the humanities, which find their institutional basis in the Graz doctoral programme Ancient Cultures of the Mediterranean and above all in the International Graduate School Resonant SelfWorld Relations in Ancient and Modern Socio-Religious Practices of the University of Graz and the Max Weber Centre in Erfurt. Several members of these two associations were involved in this conference.

Only interdisciplinarity and the cooperation of diverse scholarships make it possible to deal with complex topics in a comprehensive way, because they allow for different perspectives and methodological approaches. So, in modern times the headscarf is a nearly worldwide symbol for a specific religious and political position and a central point of many public and private discussions, which makes it a very good topic for an interdisciplinary debate of international experts of different professions. Furthermore, the historical perspective is a perfect instrument to get back to the facts and to shed light on the temporal and spatial dimensions of this important theme. 
With its wide range of subjects, the present volume is therefore a convincing example for discussing important themes of the political, religious and cultural debate of our days, like the 'most debated garment', always with the awareness of historical change. 


\title{
Introduction
}

\author{
Hannes D. Galter
}

Universität Graz, Österreich

For years now, a piece of cloth has been the focus of many public and private debates. Ideologically charged to a high degree and politically instrumentalised on a regular basis, the headscarf is probably the most argued-about piece of garment of our times. Although the sight of women wearing headscarves or veils in the streets of European cities has become familiar in recent years, the topic continues to fascinate and polarise at the same time. The debate about headscarves has caused fierce discussions about Muslims and - to a lesser degree - with Muslims, and continues to do so. In Germany, Switzerland, and France, teachers were dismissed because they refused to take off their headscarves while in Austria, an extension of the ban on headscarves in elementary schools is under discussion at the time of this writing. At an open forum at the University of Frankfurt on 16 January 2020 - accompanying the exhibition Contemporary Muslim Fashion - Naïla Chikhi, an Algerian-born women's rights activist, referred to the headscarf as the "uniform of Islamism". ${ }^{1}$

No other garment in history has become the object of more cultural fantasies and projections than the Muslim headscarf and it still serves as a fiercely contested symbol of various sociopolitical positions today.

During the economic crises of the 1970s of the past century and the associated social changes in Egypt, the headscarf quickly rose to popularity as a religious answer to women's work, compulsory schooling for girls, and the ubiquity of the visual media. In response 
to Western lifestyles, the custom of wearing headscarves was reinvented as a Muslim-feminist alternative that no longer bore the stigma of conservatism but became a modern cultural phenomenon to which new and complex meanings were assigned.

Iranian women of all ages, the so called "mothers and daughters of the revolution", have used their headscarves in a quite different way. In the wake of Vida Movahed's silent protests in 2018 they climbed on junction boxes and other public objects, removed their headscarves, and held them up in the air in protest against the regime in Tehran.

It is surprising that a simple, elementary piece of garment can provoke such strong emotions. Opponents and advocates of the use of headscarves in public refer to a wide range of historical interpretations. Many of them are heteronomous assignments of meaning that do not allow room for ambivalence. They reveal much more about those who created them than about the headscarf itself or its bearers. Some people view it as a symbol of the oppression of women in the name of religion or a patriarchal society. For others it is an indispensable part of their individual practice of religion. And some use it as a symbol in their sociopolitical confrontation with secular regimes they reject.

Headscarves are a part of almost all traditional Near Eastern apparel, documenting long-established social structures. They can be used as fashion accessories carrying meaning in colour, design, or style. In this way they play important roles in female social discourses. They can equally serve as prestige objects, which often provide a considerable increase of esteem within the social environment. And, of course, they are political symbols in various autocratic regimes in the Middle East built on religious foundations.

In the context of a perceived cultural conflict between the West and the Muslim world, the headscarf has become a highly emotionally charged buzzword. The Turkish-born feminist Nilüfer Göle wrote in 1996:

Women's bodies and sexuality reappear as a political site of difference and resistance to the homogenising and egalitarian forces of Western modernity. The contemporary veiling of Muslim women underscores the insurmountability of boundaries between Islamic and Western civilisation. ${ }^{2}$

On the other hand, the first Arab Fashion Week in Riyadh between 10 and 14 April 2018 showed how open these borders are. While Arab fashion designers such as Arwa al-Banawi presented designs inspired by European fashion - e.g. trouser suits - Jean-Paul Gaultier's 
long wide dresses and see-through veils showed an undisputable passion for oriental style.

But the headscarf could as well be simply an expression of a selfdetermined female life-concept founded on religious principles. During a "headscarf march" organised by the collective "Respect, égalité et dignité" on 3 September 2016 in Avignon, women held up signs that read "Ce n'est pas de la provocation juste ma liberté de conscience". ${ }^{3}$ And Carla Amina Baghajati, head of the School Board of the IGGÖ (Islamische Glaubensgemeinschaft in Österreich), never tires of stressing the importance of what a woman has in her head, and not what she wears on it.

Such a self-determined life-concept could be quite temporary. I remember very well a high school student in Austria, whose family came from Egypt, and who went through phases of wearing and not wearing the headscarf. She started wearing it on family request but dropped it after some time. Later she used it again, this time out of her own conviction. As far as I know, she finally dropped it after graduation.

So, what is the headscarf? Is it a religious necessity, and if so, in which religious contexts? Is it a political signal, and if so, for what? Is it a sign of social discrimination and therefore alien to European culture? Is it part of traditional attire and thus an indication of premodern attitudes?

As with many other cultural-historical questions, the answers are extraordinarily complex and often ambiguous. We can only try to shed some light on various aspects and by doing so come closer to possible answers. But it will be necessary to recognise the complexity and heterogeneity of the phenomena and to clearly separate the different issues from each other. And we should always keep an eye on historical developments. Such developments are not limited to recent history. Sometimes they go back a long way into the past and sometimes they connect the remotest epochs.

One such example is the case of Muazzez İmiye Çiğ, a renown Turkish Sumerologist who faced a court trial for stating the historical truth that the veil was used millennia ago to distinguish daughters of rich and influential families working in temples from other groups of women. ${ }^{4}$

In 2004, at the age of 90, she published a book about her convictions as a person brought up in the spirit of Kemal Atatürk and a lifelong feminist. ${ }^{5}$ Vatandaşlık Tepkilerim (My Reactions as a Citizen) is a compilation of political articles she published in the 1990s and let-

3 Le Dauphiné 2016.

4 Eko 2016, 1-4.

5 Çiğ 2004. 
and letters she wrote to Recep Tayyip Erdoğan when he was mayor of Istanbul. In one of these letters she argues that the veil was used during the Sumerian period in the third millennium BCE to distinguish women of different social levels from each other. The example she gave were priestesses who celebrated the Sacred Marriage Rite which included ritual sex.

Therefore, she argued, veils and headscarves are no appropriate symbols for woman's morality or religious devotion. Her argument that linked the headscarf with ritual sex prompted an Islamic-oriented lawyer in Izmir, Yusuf Akin, to file a complaint against her for inciting hatred by insulting people because of their religion.

Muazzez Çiğ was taken to court in 2006, facing a verdict of eighteen months in prison in case of conviction. When the trial started on 1 November, fifteen secular lawyers showed up to defend her for free, and the state prosecutor himself asked the judge to drop the charges. The court ruled after less than half an hour that as a scholar her actions did not insult Islam and therefore did not constitute a crime. Muazzez Çiğ was acquitted of all charges. ${ }^{6}$ In the meantime, the International Association for Assyriology had drafted an appeal for dismissal of charges against the Sumerologist, which almost 150 colleagues signed. It was suspended when the news of the court ruling spread.

Muazzez Çiğs's case casts a light on the interconnections between the political and religious systems of today with the cultural heritage of Mesopotamia. Against this background, the papers in this volume attempt to cover the cultural spectrum from the cultures of the Ancient Near East to present day Islam. They were originally presented at an international congress, Il velo femminile dall'Antico Oriente all'Islam / Kopftuch und Schleier vom Alten Orient bis zum Islam held at the University of Graz in March 2020, only days before the general academic lockdown in Austria and Europe.

I would like to thank the A.C.CulturArti in Udine, the Institute of Classics of the University of Graz, and the Urania in Graz for taking up this topic and organising the congress. My thanks also go to Lucio Milano and the Edizioni Ca' Foscari for including this volume in their publishing programme and for the highly professional editorial work. Finally, I am grateful to Mario Fales who brought up the idea of this congress years ago and who did not rest until it had become a reality. 


\section{Bibliography}

Arsu, S. (2006). "Turkish Scholar Who Mocked Head Scarves Is Acquitted”. The New York Times, 2 November. https://www. nytimes.com/2006/11/02/ world/europe/O2turkey.html.

Chikhi, N. (2020). "Ich fragte sie, ob ich ihnen nicht muslimisch genug sei. Keine Antwort". Die Welt, 18 January. https://www.welt.de/debatte/ plus205129536/Eklat-an-Uni-Frankfurt-Ich-fragte-ob-ichnicht-muslimisch-genug-sei.html.

Çiğ, M. (2004). Vatandaşlık Tepkilerim. Istanbul.

Eko, L. (2016). The Regulation of Sex-Themed Visual Imagery. From Clay Tablets to Tablet Computers. London.

Göle, N. (1996). The Forbidden Modern. Civilization and Veiling. Ann Arbor.

Le Dauphiné (2016). "Une marche pour le port du voile". Le Dauphiné, 4 September. https://www.ledauphine.com/vaucluse/2016/09/04/unemarche-pour-le-port-du-voile. 



\title{
Veil and Headscarf: Five Aspects of a Cultural Phenomenon
}

Hannes D. Galter

Universität Graz, Österreich

\begin{abstract}
The discussions about the use of headscarves and veils shape the living conditions of Muslim women in the Middle East and in Europe to this day. To overcome this situation, a thorough and dispassionate documentation of the cultural history of veiling is necessary. This paper will give a short overview of the long history of veiling and it will deal in detail with five different aspects of this phenomenon and with the various connections between Europe and the Middle East: the relationship between death and the veil in the Ancient Near East; the veil in early Christianity; the hair as an erotic symbol in the Ancient Near East; the traditional costume of the Transylvanian Saxons as a European example of the use of veils and the veil of mystery.
\end{abstract}

Keywords Veil. Headscarf. Mesopotamia. Palmyra. Transylvania. Maraş. Death. St. Paul. Tertullian.

Summary 1 Veiling in the Ancient Near East. - 2 Death and the Veil in the Ancient Near East. -3 The Veil in Early Christianity. - 4 Hair as an Erotic Symbol in the Ancient Near East. -5 Headscarves and Veils in the Traditional Costume of Transylvania. -6 The Veil of Mystery.

\section{Veiling in the Ancient Near East}

The use of headscarves and veils is not limited to Muslim societies. It has been known for decades that this phenomenon has an exceptionally long history within Near Eastern cultures. ${ }^{1}$ Already during the third

1 Stol 2016, 22-8. See also Jeremias 1931; de Vaux 1935; van der Toorn 1995; Galter 2001; Vogelsang-Eastwood, Vogelsang 2008, 23-6. This paper is an extended version 
millennium BCE, statues like the well-known one from Mari show females with their head covered by a cloak or a shawl. It is still not clear if this veiling was a common practice or restricted to certain occasions or certain groups of persons. In the case of the woman from Mari, the seated position and the polos on her head would indicate an affiliation with the elite. It has recently been speculated that she is a queen. ${ }^{2}$

Our main sources for head-coverings come from objects of art: sculptures, reliefs, paintings, votive plaques, and cylinder seals. Since many of the images are rather small and in almost all cases the original colours have been lost, it is often impossible to distinguish different styles. In the texts numerous designations for headscarves and veils occur, ${ }^{3}$ but unfortunately in most cases we know nothing about their appearance, size, or use.

Head coverings are attested for both men and women. ${ }^{4}$ Men commonly wear a headband or a bonnet, women a headscarf or a veil. The hem (sissiktu) of the garment could, among other things, also be used to cover the head and sometimes the face, but for the most part detailed information on its use in covering the face or body are lacking. Goddesses were said, too, to wear a veil, for example Aya, Ninlil, Ninsun, and Nanaya. The latter one was specifically referred to as "the veiled one among the goddesses" (pusumti iläti) by the scribes of Esarhaddon. ${ }^{5}$

It seems that the veil was not in common use in Sumer during the third millennium BCE - we do not know any Sumerian word for it - but was instead more popular in the north and west of Mesopotamia. Nevertheless, the picture is far from clear. Because the earliest attestations for the veil come from Ebla and Mari, Hartmut Waetzoldt thought that the use of the veil occurred first in the north and west and then spread to Babylonia. ${ }^{6}$ On the Assyrian palace reliefs, veiled women tend to be depicted in western (Syrian and Levantine) contexts rather than in southern (Babylonian) ones. ${ }^{7}$ This could be an indication that use of the veil originated in ancient Syria, but at the moment this is still an assumption.

Originally, headscarves and veils were used to protect a person from cold, wind, sand, or the sun [fig. 1]. This use is still practiced to-

\footnotetext{
of the introductory presentation given at the conference. It deals with aspects not covered by the other contributions within this volume. I would like to thank Florian Ksugas for his valuable help in $\mathrm{w}$ the pitfalls of the English language.

2 Otto 2016, 118-20.

3 Waetzoldt 1983, 200-3.

4 Börker-Klähn 1972; Boehmer 1983; Van der Toorn 1995, 327-8; Galter 2001, 14.

5 Waetzoldt 1983, 202; Stol 2016, 27. For the various designations for the veil see Van der Toorn 1995, 327-30; Galter 2001, 14-15 and Giovanna Biga in the present volume.

6 Waetzoldt 1983, 203.

7 See Stol 2016, 25-6.
} 


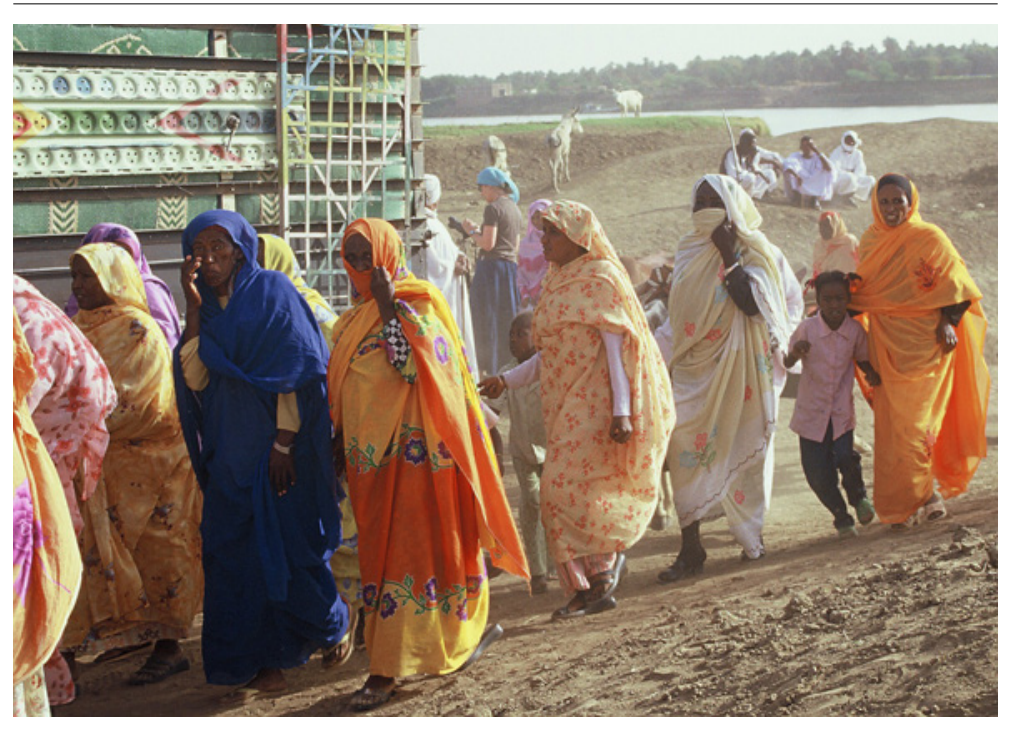

Figure 1 Women at the ferryboat at ed-Debbah in Sudan (photo H.D. Galter 2004)

day in North-African and Near Eastern societies, and it is not restricted to women, as examples from Berber and Tuareg communities show. ${ }^{8}$

This protection was soon transferred to the immaterial realm. Head and face were regarded as particularly vulnerable due to their prominent position and all their orifices. They were exposed to threats such as demons, witchcraft, the evil eye, or - in the case of women - the covetous glances of men and therefore in need of extra protection.

This protection was especially necessary in phases of transition, ${ }^{9}$ e.g. during puberty for girls, in the bridal state, ${ }^{10}$ during the mourning period, ${ }^{11}$ or at one's own death. Accordingly, we can distinguish different social contexts for veiling: the veiling of the bride, the covering of the head during religious ceremonies, the enshrouding of the dead, or the public veiling of married women. In Mesopotamia, so it seems, veils were originally only worn during wedding ceremonies ${ }^{12}$ and only later became a sign of modesty for all married women. ${ }^{13}$

8 See the various contributions to the exhibition catalogue Steinmann 2018.

9 Synnott 1987, 409-10; Pergament 1999, 44.

10 Stol 2016, 22-4.

11 Synnott 1987, 409; Hershman 1974, 283-6.

12 Tsevat 1975; Van der Toorn 1995, 330-8. Brigitte Groneberg (2000, 3) compared the veil of the bride with the veil of the Mesopotamian priestess since in her opinion both became married women.

13 Stol 2016, 26-7. 
In addition, clothing served - and still does today - to distinguish group members from non-members and to convey an individual's position in society. It informs about the social status, the occupation, the phases of life, the emotional state, or, nowadays, the political views of a person. Headscarves and veils were already used in the Ancient Near East to distinguish urban elite women from prostitutes or slave girls, as is amply documented in various law collections. ${ }^{14}$

In ancient Israel, the veil appears to have been in use in an upperclass urban environment at least from the 6th century BCE onwards. The prophet Isaiah $(3,18-23)$ mentions the récalâ, apparently a small face veil among the accessories of the well-situated Jerusalem women. ${ }^{15}$ The veiling of women in public is also mentioned in other passages of the Old Testament, for example at the first meeting of Isaac and Rebekah (Genesis 24,65). The Moabite woman Ruth also covered herself with a cloth when she went to Boaz in Bethlehem (Ruth 3,15). And when Tamar forced Judah, the father of her deceased husband, to take care of her, the veil played an essential role. Tamar discarded the garment of her widowhood, wrapped herself in a șāîn, a kind of cloak, and sat down at the town gate. Judah saw her but did not recognise her. They had intercourse, Tamar became pregnant and thus remained part of the family (Genesis 38,11-26). ${ }^{16}$ Contrary to sedentary urban habits, nomadic women mostly remained unveiled (cf. Genesis 12,14 or 24,15).

From the 2nd century CE onward, veiling seemed to be common practice in Palestine and the Middle East. The Babylonian Talmud refers several times to the veiling of the woman. The tractate Ketubot (72) comes to the conclusion that a married woman should cover her hair under normal circumstances. It does so by quoting the Sotah-ritual, a fidelity test for women accused of adultery (Numbers 5,18). On the other hand, the Mishnah in Ketubot $(7,6)$ mentions the behaviour of "going out with her head uncovered" as an offense against Jewish practice and not against Mosaic law. ${ }^{17}$ In the tractate Eruvin (100), the covering of the woman's head is described as part of the ten curses put on Eve for transgressing the divine mandate.

Until the 20th century CE, orthodox Jewish married women in the Middle East and in Europe covered their heads in public with a headscarf (tichel). These coverings could range from simple square pieces of cloth tied in the back to elaborate head coverings using multiple fabrics and tying techniques. As social constraints made it more and more difficult, some used a wig (sheitel) instead to fulfil their need

14 Galter 2001, 17-19; Stol 2016, 26 and Mario Fales in the present volume.

15 Van der Toorn 1995, 330; Galter 2001, 19.

16 Van der Toorn 1995, 330; Galter 2001, 19.

17 See also Tosefta Sotah 5. 
for modesty. Although the general practice of covering one's head in public is slowly fading in Western culture, it is still common practice in ultra-orthodox Jewish communities. ${ }^{18}$

Outside of Middle Eastern cultures, the veiling of the female head was also part of everyday life for the upper classes. In the Homeric epics, the predominant garments of women are the heanos (Éavós) ${ }^{19}$

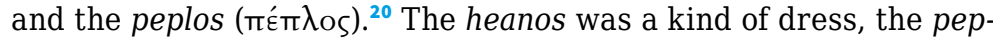
los probably some sort of cloak or outer garment covering the whole body. This cloak could be pulled in front of the face. It might not have originated from Greece but from Asia Minor, since there is no evidence for its existence in Minoan-Mycenaean art. During the Roman Empire, the Greek traditions lived on. Upper-class women covered their bodies with a cloak (palla) in public. A fine example is found in a mural painting of the Villa dei Misteri in Pompeii from the middle of the 1st century BCE. The poet Horace criticised the veiling of elite women, saying that a man can see nothing but the face of a matron, who carefully conceals her other charms. A courtesan, on the other hand, shows her goods before she takes the money. ${ }^{21}$

In the Parthian art of Dura Europos (e.g. in the "Salvation of Moses" from the synagogue), Hatra, and Palmyra, women with headscarves are regularly present. From Hatra we have images of goddesses and queens with long veils over their elaborate headgears, such as the statue of Abu Bint Deimun, wife of Sanatruq I (167-190 CE) [fig. 2].

On murals and funeral reliefs in Palmyra, women's and men's costumes differ primarily in the veil and jewellery. We will deal with these images below.

Headscarves were also worn in pre-Islamic times on the Arabian Peninsula, specifically by upper-class women as a sign of honour and distinction. ${ }^{22}$ Three or four generations after the death of $\mathrm{Mu}$ hammad, the habit of veiling spread to all parts of society and was adopted into the religious canon of social behaviour. ${ }^{23}$ How and to what degree Persian and Byzantine practices influenced this development remains to be investigated.

18 See in general Salzberg s.d.

19 E.g. Il. 3.385; 4.19; 16.9; 23.254.

20 E.g. Il. 5.315; 8.385; 23.254; Od. 15.105-106; 18.292.

21 Hor. Sat. 1.2 (Ambubaiarum collegia): 94-105.

22 Vogelsang-Eastwood, Vogelsang 2008, 35-7.

23 Esposito 2002, 95-8. 


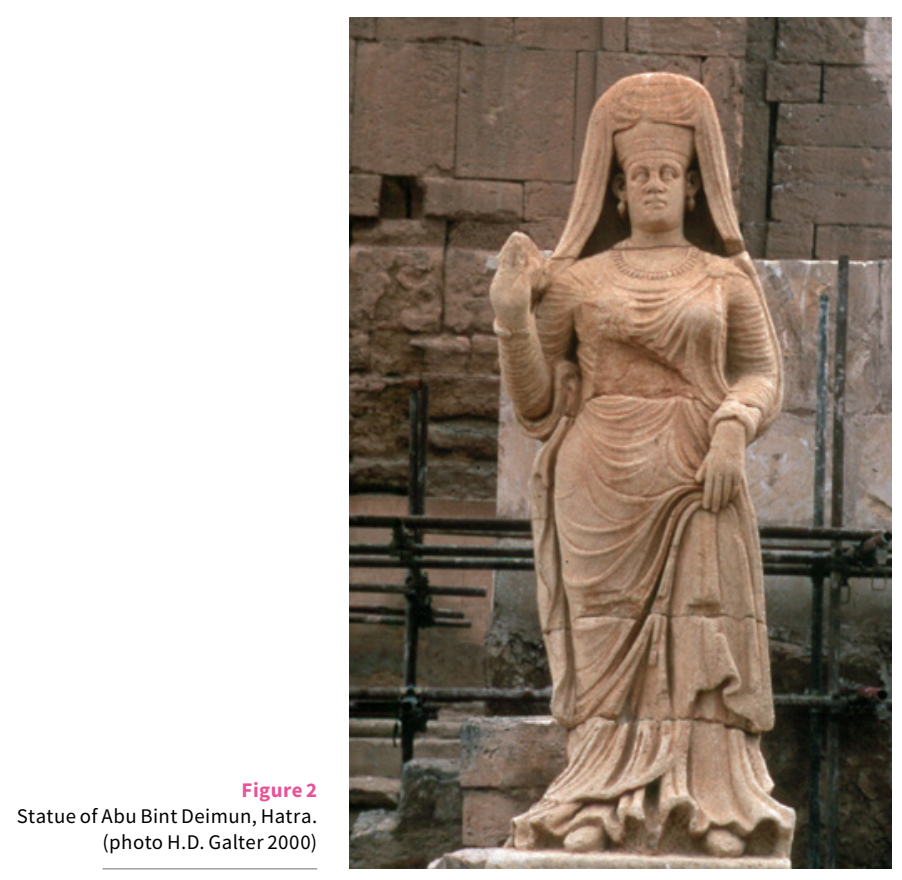

\section{Death and the Veil in the Ancient Near East}

Tablet 8 of the standard Gilgamesh epic contains the death lament of Gilgamesh for Enkidu. Line 59 reads in the translation of Andrew George: "He covered (his) friend, (veiling) his face like a bride". ${ }^{24}$ The Akkadian verb katāmu "to veil etc." was regularly used for the veiling of the bride and its derivation kutummu was one of the main designations for the veil that covered the head and the face of the bride. ${ }^{25}$ This veiling of the dead seemed to be a common practice in the Ancient Near East. This tradition is still followed today in Jewish and Muslim funerals when the deceased is wrapped in a plain burial shroud. According to the Gospels, Jesus was also buried in accordance with Jewish law:

Joseph bought a linen cloth, took Him down, wrapped Him in the linen cloth and laid Him in a tomb which had been hewn out in the rock. (Mark 15,46, NASB) 
To cover one's head and face was generally considered a sign of mourning, ${ }^{26}$ but in our case we are dealing with the covering of the face of a dying or dead person. For this we have much fewer attestations.

Caesar allegedly pulled the folds of his toga over his head so as to prevent anyone from seeing his face at death. ${ }^{27}$ The same is said about Socrates. ${ }^{28}$ The murals in the tombs of Palmyra show this "veil of death" is sometimes depicted between columns or palm leaves, as in the painting on the right arch pillar of the main gallery of the hypogeum of the three brothers from the 4th century CE.

On this painting, the deceased has her head and upper body covered by a long veil too. Similar veils appear on other murals, e.g. the one on the left arch pillar of the main gallery or the medallions on the left side of the main gallery. ${ }^{29}$ The question remains whether these examples were part of the funeral rites or a symbol of wealth and social standing. In other words, were the women presented veiled because they had died, or because the belonged to the upper-class of Palmyra?

The connection between veiled women and funerary monuments in Syria and Anatolia goes back at least to the 9th century BCE. There is a large group of basalt steles from Iron Age Kahramanmaraş that relate to funerals and memorial rites. Most of them show banquetscenes with the deceased sitting at an offering table and one or two standing attendants. ${ }^{30}$ Periodic banquets played an important part in the Ancient Near Eastern memorial rites (kispu). ${ }^{31}$ The texts on some other steles indicate that the deceased were supposed to share the sacrifices of food and drink prepared for the deities. ${ }^{32}$ The depicted persons, mostly husband and wife, but sometimes also parents with their children, are holding different objects in their hands. These could have been symbols of gender, social status, or occupation. Common male attributes were stylus and writing board, bow and sword, or a balance.

26 Compare Samuel 15,30; Jeremiah 14,3-4 or Esther 6,12.

27 Suet. De vita Caesarum 1.82.

28 Pl. Phd. 118.a6.

29 See Ruprechtsberger 1987, 59, fig. 18 and the images on the "Tombs of Palmyra", website of Michael Fuller: http://users.stlcc.edu/mfuller/palmyratombs.html.

30 Orthmann 1971, 366-93 (Maraş A/2, Maraş B/7, Maraş B/8, Maraş B/12, Maraş B/14, Maraş B/19, Maraş B/20, Maraş B/21, Maraş C/1, Maraş C/2, Maraş C/3, Maraş C/5, Maraş D/3); Bonatz 2000, 34-44 and pl. 12-23 (C 22, C 25, C 27, C 33, C 34, C 51, C 60, C 62, C 64, C68). Compare Hawkins 1980 and 2000, 249-58.

31 See Tsukimoto 1985.

32 See Struble, Rimmer, Herrmann 2009. 
The female figures wore long gowns and a veil or cloak covering their heads. They hold a distaff, ${ }^{33}$ a mirror, ${ }^{34}$ or a pomegranate ${ }^{35}$ in one hand and a cup or beaker in the other. Sometimes they carry a musical instrument ${ }^{36}$ or two poppy capsules. ${ }^{37}$ Mirror and distaff were typical female attributes in the Ancient Near East.

The funerary stele of Tarhuntiwastis, for example, shows two seated women with long veils at opposite sides of an offering table. Both have a polos-type headgear under the veil. One holds a distaff and a mirror in her hands, the other a distaff and a cup. The inscription says that Azinis had set up this stele with the womanly (?) image of his wife Tarhuntiwastis. Since only one woman is mentioned in the text, it is generally assumed that both images represent Tarhuntiwastis. The stele dates to the 9th century BCE and is housed in the Ancient Oriental Museum in Istanbul (EŞ 7694). ${ }^{38}$

A basalt stele on display at the Adana Museum (Inv. 1956) shows a seated woman at the left side of an offering table [fig. 3]. She is wearing a long veil over a headgear that is adorned with numerous rosettes and she is pulling a thread from a distaff that she holds in her left hand. At the right side of the table, a younger male figure (her son?) is standing with a stylus and a writing board in his hands. The stele dates to the end of the 8th century.

A different scene is depicted on the funerary stele of Tarhupiyas in the Louvre (AO 19222). ${ }^{39}$ It dates to the second half of the 8th century BCE and was acquired from the antiquities market. Therefore, we cannot be sure about its origin, but the image and the stylistic similarities point to the region of Kahramanmaraş. The image shows a seated woman wearing a veil and a boy standing on her knees. He holds a stylus in his right hand and a bird is tied to his left hand. A hieroglyphic Luwian inscription gives the personal name Tarhupiyas, but the inscription was incised at a later date.

In 1989 a mortuary monument in the form of a rectangular altar was found during construction work in Kahramanmaraş. ${ }^{40}$ The monument is made of dark basalt and is decorated with reliefs on all four sides. The front face shows a seated woman en face sitting on a cline

33 E.g. Orthmann 1971, pl. 47 (Maraş C/5).

34 E.g. Orthmann 1971, pl. 45 (Maraş B/7, B/12, B/14).

35 E.g. Orthmann 1971, pl. 43 (Maraş A/2) and pl. 46 (Maraş B/20).

36 E.g. Orthmann 1971, pl. 46 (Maraş B/19).

37 E.g. Orthmann 1971, pl. 47 (Maraş C/2) or pl. 57 (Zincirli B/3).

38 Orthmann 1971, pl. 45 (Maraş B/7); Hawkins 2000, 273-4 and pl. 124 (MARAŞ 2); Bonatz 2000, pl. 14 (C 33).

39 Orthmann 1971, pl. 48 (Maraş D/4); Hawkins 2000, 274-5 and pl. 125 (MARAŞ 9); Bonatz 2000, pl. 22 (C 65).

40 Schachner, Schachner 1996. 


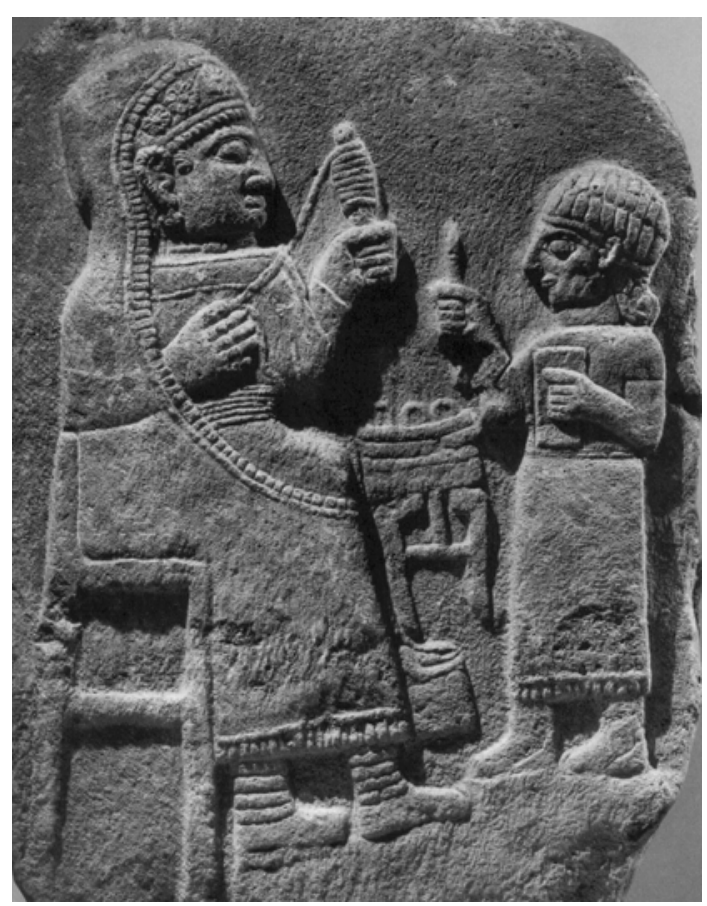

and pulling a thread from a distaff that she holds in her left hand. She is also wearing a long veil over a headgear heavily decorated with rosettes. She is flanked by two younger women (her daughters?), who are also dressed in large cloaks covering their heads and carrying a fan and a flywhisk, respectively. The other side shows a procession of veiled musicians. The monument dates to the 8th century BCE and is on display at the Antakya Museum.

These kinds of images were not restricted to Kahramanmaraş. A similar stele was found in Zincirli ${ }^{41}$ and a limestone orthostat from the Long Wall in Carchemish and now in the Museum of Anatolian Civilisations in Ankara shows a seated female figure dressed in the same way with a long veil covering her head and upper body. The four-line inscription on the background of the seated figure identifies her as Watis, the wife of the ruler Suhis II. ${ }^{42}$ Although this representation is not on a stele, it has been suggested to be posthumous because the figure is presented larger than other humans and in com-

42 Hawkins 2000, pl. 8. 


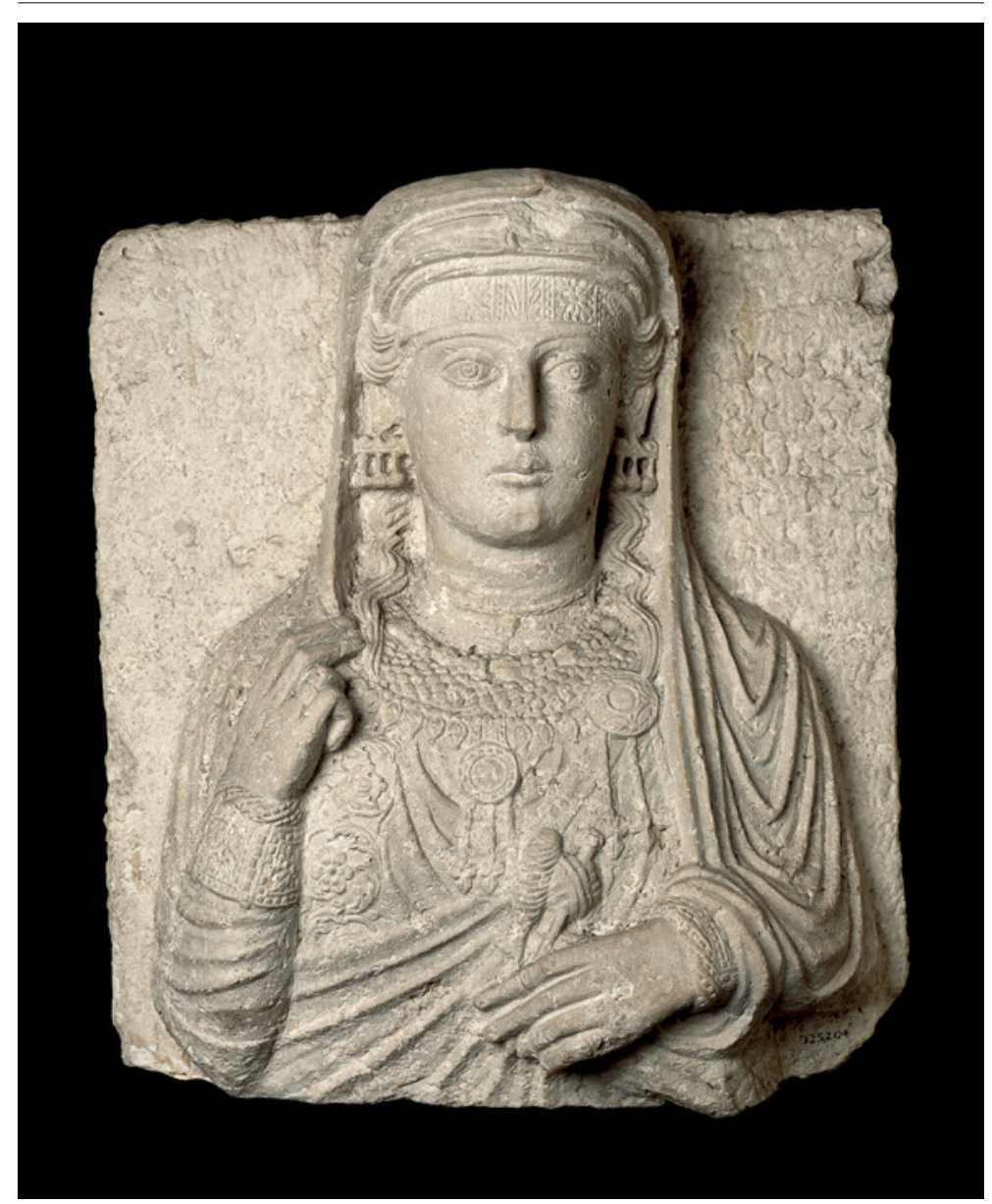

Figure 4 Funerary relief of Tamma, daughter of Šamšigeram. BM 125204 (photo @ The Trustees of the British Museum)

pany of the gods. She is sitting on a cline similar to the one in the Antakya Museum.

All these monuments show the deceased women wearing a long veil. But again, we cannot decide whether the veil is indicating the death of the lady or her high social standing. One stele from Tell Fredje, north-east of Hama, shows a banquet-scene with a seated female figure on the right without a veil..$^{43}$ On the other hand, the two young women and the musicians on the altar from Kahramanmaraş 
are veiled. This could support the argument that the veil is an indication for a higher social status. But it could also mean that the women are taking part in a religious ceremony as do the group of priestesses on the reliefs of the Procession Entry in Carchemish. ${ }^{44}$

In Palmyra, women wearing a long cloak over their heads are depicted on numerous funerary reliefs like the one of Tamma, daughter of Šamšigeram, dating to 50-150 CE, now in the British Museum [fig.4]. These reliefs are the most important group of objects from Palmyra. The square slabs of local limestone, which were used to seal the burial niches (loculi) in the tower tombs and hypogea, show busts in high relief depicting the deceased person and occasionally other family members in a frontal pose. They date to the period between the 1st century BCE and the 3rd century CE. After the Roman conquest of Palmyra in $273 \mathrm{CE}$, the reliefs ceased to be produced. ${ }^{45}$

The funerary portraits were heavily shaped by Roman influences but nevertheless developed a distinctive local style incorporating features from Persian and Mesopotamian art. ${ }^{46}$ They usually depict the individual down to the waist, thereby creating more space for the display of visual elements such as spindle and distaff, clothing, jewellery, or an elaborate headgear.

Palmyrene funerary portraits were not meant to depict the real person. They were representations of the personality and prestige of the deceased and they granted a continuing relationship with their families. ${ }^{47}$ Therefore, the adornments were used to show the social standing or individual situation of the deceased. They were the major means of individualisation. ${ }^{48}$

The women on these reliefs wear various combinations of a tunic, cloak or veil, headband, and turban. Their right hand is often raised, sometimes holding the veil or a fold of the cloak, sometimes touching their cheek. Other female figures are depicted holding a spindle or distaff as sign of femininity in their left hand. Some reliefs show women holding keys, calendars, or children. ${ }^{49}$ In the beginning these domestic symbols were predominant and almost no jewellery appeared. Gradually, the use of these symbols declined and with the increase of wealth in Palmyra women began wearing earrings, bracelets, rings, and necklaces. Almost all of them wear a veil or a piece of cloth over their heads. In the 3rd century holding the veil became the common gesture of the images. ${ }^{50}$

Orthmann 1971, pls 29-30.

45 Heyn 2010, 632.

46 Raja 2017.

47 Heyn 2010, 634.

48 Sokołowski 2017, 24-8; Klaver 2019, 123-4.

49 Heyn 2010, 635.

50 Chehade 1987; Heyn 2010, 636. 
On the other hand, there is a group of female funerary portraits depicting women with unveiled heads. This is rather unusual, since Palmyrene women were typically depicted with at least part of their heads covered by a veil. These representations were interpreted as western influences in the time following Hadrian's visit to Palmyra in $129 \mathrm{CE} \cdot{ }^{51}$ Another group of busts with long open hair is believed to represent widows mourning their deceased husbands. ${ }^{52}$

As before, the funerary reliefs from Palmyra raise the same question as the steles from Kahramanmaraş: Does the veil indicate the death of the woman or her high social standing?

Most scholars agree that the clothing and the jewellery were part of the costume of upper-class women in Palmyra and pay tribute to the prestige and wealth of the deceased. On the other hand, Cynthia Finlayson postulated that the various female headdresses indicated religious, tribal, and family associations..$^{53}$ Nurith Kenaan-Kedar has focused on yet another feature of the reliefs. She argued that the images of women with extensive jewellery reflect the belief in the goddess Ištar/Astarte of Palmyra. The rich sets of jewellery depicted in the reliefs should be seen as a reflection of the jewellery of Ištar/ Inana that she wore on her descent to the netherworld and of the hope for a resurrection similar to the one described in the Sumerian and Akkadian tales. ${ }^{54}$

This opens a new line of thought. From the earliest times onward, people in the Ancient Near East were buried with their best clothes and jewellery to pay testament to their social standing and their prestige. By this act they sought to ensure a corresponding position in the netherworld. The stories of Inana's or Ištar's descent are telling examples for this belief. The goddess adorns herself with her best clothes, jewellery, and accessories, including a wig and a headscarf, before departing for her journey. ${ }^{55}$ Mesopotamian women behaved in a similar way, as is amply documented by the royal tombs of $\mathrm{Ur}^{56}$ or the tombs of the Assyrian Queens at Nimrud. ${ }^{57}$

The funerary reliefs from Palmyra are evidence for the same beliefs and hopes. Since the veil symbolised their belonging to the elite, they might also have used it as part of their burial gown. ${ }^{58}$ Wheth-

51 Parlasca 1987; Krag, Raja 2018.

52 Heyn 2010, 637.

53 Finlayson 1998, 710-43; Klaver 2019, 126-7.

54 Kenaan-Kedar 2012; Compare ETCSL 1.4.1 and Foster 1996, 402-09; see also infra.

55 ETCSL 1.4.1: 14-25.

56 Zettler 1998.

57 Damerji, Kamil 1999.

58 In another chapter below I will analyse the traditional headscarves and veils of the Transylvanian Saxons. It was common practice to bury a woman with her veil or 
er the raised hand holding the hem of her cloak or veil that we see on numerous reliefs is indeed a variant of the Roman pudicitia gesture, indicating modesty and fidelity, remains uncertain. ${ }^{59}$ It might well belong to the group of gestures discussed at the beginning of this chapter.

\section{The Veil in Early Christianity}

The idea that an honourable woman must cover her head in public and in prayer was already present in early Christianity. The 11th-century Byzantine empress Irene Doukaina (c. 1066-1138) is portrayed as a model of modesty and virtuousness by her daughter Anna Komnena. She mentions that her mother carefully observed the paradigm of ideal behaviour and even covered her eyes and elbows. ${ }^{60}$ This paradigm was largely based on the First Epistle of Paul to the Corinthians. In this letter the apostle demands that women should cover their heads during the community prayer:

Be imitators of me, just as I also am of Christ. Now I praise you because you remember me in everything and hold firmly to the traditions, just as I delivered them to you. But I want you to understand that Christ is the head of every man, and the man is the head of a woman, and God is the head of Christ.

Every man who has something on his head while praying or prophesying disgraces his head. But every woman who has her head uncovered while praying or prophesying disgraces her head, for she is one and the same as the woman whose head is shaved. For if a woman does not cover her head, let her also have her hair cut off; but if it is disgraceful for a woman to have her hair cut off or her head shaved, let her cover her head. For a man ought not to have his head covered, since he is the image and glory of God; but the woman is the glory of man. For man does not originate from woman, but woman from man; for indeed man was not created for the woman's sake, but woman for the man's sake. Therefore the woman ought to have a symbol of authority on her head, because of the angels.

However, in the Lord, neither is woman independent of man, nor is man independent of woman. For as the woman originates from the man, so also the man has his birth through the woman;

her headscarf in addition to her burial shroud. All this was prepared already during her lifetime. See Schmidt, Förderreuther 2011, 73.

59 See the discussion in Heyn 2010, 635-6.

60 See Garland 1988, 373. 
and all things originate from God. Judge for yourselves: is it proper for a woman to pray to God with her head uncovered? Does not even nature itself teach you that if a man has long hair, it is a dishonor to him, but if a woman has long hair, it is a glory to her? For her hair is given to her for a covering. But if one is inclined to be contentious, we have no other practice, nor have the churches of God. (1 Corinthians 11,1-16, NASB)

No other passage in the New Testament has provoked such heated discussions - and continues to do so - as this one. ${ }^{61}$ The text was used to argue for a general duty to veil women in public. It was interpreted in such a way that women in some radical protestant communities like the Russian Baptists, the Mennonites, the Amish, and the Hutterites always wear a veil, a headscarf, or a bonnet. Others refer to the safeguarding of the honour of the community ${ }^{62}$ or to the necessity of keeping these traditional markers of anthropological difference. ${ }^{63}$ The passage even served as evidence that Paul rejected the veiling of women. ${ }^{64}$ Cynthia Thompson compared the descriptions in Paul's letter with the statues of women from ancient Corinth. ${ }^{65}$ She came to the conclusion that Paul's description was in harmony with Greco-Roman customs. Even the line "for her hair is given to her for a covering ( $\pi \varepsilon p 1 \beta o \lambda \alpha$ áov)" reflected local conventions for long hair to be tied up and not to be kept unbound. ${ }^{66}$ With only a few exceptions, the statues from Corinth depict women with long hair arranged into skilful and complex hairstyles. Torsten Jantsch follows the same line of thought. He is convinced that the text is not about a textile head-coverings but about a woman's hair, more precisely about the right hairstyle. ${ }^{67}$

The letter formed part of a long running correspondence between the apostle Paul in Ephesus and the Christian community in Corinth. It was probably written about 53-4 CE. Two or three years earlier, Paul had visited the city and established the community there. In the meantime, questions of public religious practice arose, and the apostle dealt with them. At the same time, he addresses topics such as religious ceremonies, marriage and celibacy, immorality, and the right conduct of women.

In the middle of the first century $\mathrm{CE}$, Corinth was a port city with a booming economy and a large and diverse population. This tre-

61 For a history of research on this text see Jantsch 2015a and Marshall 2017, 9-41.

62 Finney 2010.

63 BeDuhn 1999.

64 Schirrmacher 2007.

65 Thompson 1988.

66 Thompson 1988, 112.

67 Jantsch 2015b. 
mendous cultural, social, and religious diversity was certainly reflected in the traditions and beliefs that the members of the Christian community brought along. There were substantial differences between dress codes for women in Greco-Roman Corinth, Syria, and Asia Minor, the areas Paul was familiar with. ${ }^{68}$ In this letter Paul tried to make traditional oriental Christian social concepts mandatory among the new believers. ${ }^{69}$ One of these concepts was the gender hierarchy deduced from the creation-account in Genesis. A similar attempt is apparent in his somewhat later letter to his younger Greek colleague Timothy:

Therefore I want the men in every place to pray, lifting up holy hands, without wrath and dissension. Likewise, I want women to adorn themselves with proper clothing, modestly and discreetly, not with braided hair and gold or pearls or costly garments, but rather by means of good works, as is proper for women making a claim to godliness. A woman must quietly receive instruction with entire submissiveness. But I do not allow a woman to teach or exercise authority over a man, but to remain quiet. For it was Adam who was first created, and then Eve. And it was not Adam who was deceived, but the woman being deceived, fell into transgression. But women will be preserved through the bearing of children if they continue in faith and love and sanctity with self-restraint. (1 Timothy 2,8-15, NASB)

But in the letter to the Corinthians, so it seems, he nevertheless established rules for women praying and prophesying in public, a function that was common in Corinth ${ }^{70}$ but did not exist in ancient Judaism and that he himself will later ban in the letter to Timothy.

The keyword in our text is the Greek exûsia ('ُگovoía), that was translated in the quote as "authority". But the word has a wide range of meanings such as "power", "mandate", "leverage", "freedom of choice", "crown (as a symbol of royal authority)", or even "veil (as a symbol of authority of the husband)". In the Vulgate, the Latin word potestas is used. Therefore, the sentence "for this cause ought the woman to have (a sign of) authority on her head, because of the angels" could mean that she has to cover her head as a sign of her temporary religious authority when she acts publicly during service ("praying or prophesying"). ${ }^{71}$

During the following centuries, the veil became an established part of Christian tradition. By receiving religious significance, the

68 Thompson 1988, 113.

69 Lampe 2012; compare Delleman 2013, 14-19.

70 See Marshall 2017, especially 73-108.

71 Compare Lambin 1995 and Du Toit 2015. 
use of the veil spread in the West of the Roman empire more widely than in the East.

The early Christian author Tertullian (c. 150-225 CE) from Carthage contributed decisively to this development. He was the first one to produce an extensive corpus of Latin Christian literature and therefore can be regarded as the "founder of Western theology".72 Around $209 \mathrm{CE}$ he wrote the work De virginibus velandis ("On the veiling of virgins") because of a headscarf-controversy that erupted in Carthage in the wake of Paul's 1st letter to the Corinthians. This controversy had much in common with modern debates about the use of the veil in public schools. It seems that there were different views on the veiling of women and girls during service and in public. ${ }^{73}$ The main question that arose was whether young unmarried girls (virgines) should wear a veil during service in the same way as married women should or not. Tertullian came to a positive conclusion but went one step further in his argumentation. He demanded the veiling of girls starting from puberty even outside the church (extra ecclesiam). His understanding of Paul's letter was that all women, regardless of origin, rank, situation, dignity, or age had to wear a veil. ${ }^{74}$

Tertullian used well-known arguments for his explanation: the topos of modesty and the statement that men are easily seduced by the sight of unveiled girls. ${ }^{75}$ Like Paul in his letter he made comparisons to nature, but he also referred to traditions in his North-African environment, where the veiling of women in public was standard practice.

Tertullian particularly mentioned a passage in Genesis $(6,1-2)$ that speaks about the marriage between the sons of God and the daughters of men. He argued that even angels had succumbed to the temptation of female beauty. Therefore, all men, regardless of age and social status, were at risk: sons by their mothers, brothers by their sisters, or fathers by their daughters. He concluded that, consequently, all women had to be veiled. ${ }^{76}$

This conclusion already anticipated the traditional Muslim gender discourse that is still going on today. The main argument put forward is that women hold a broad sexual attractiveness which must be strictly controlled. Otherwise, men are prevented from carrying out their religious and social duties which will disrupt the established social order. Veiling protects men from female eroticism and women from male sexual harassment. Tertullian's work ends with the observation:

73 See Fellman 2009.

74 Elssner 2004, 328.

75 Dunn 2005.

76 Elssner 2004, 322-3. 
Hannes D. Galter

Veil and Headscarf: Five Aspects of a Cultural Phenomenon

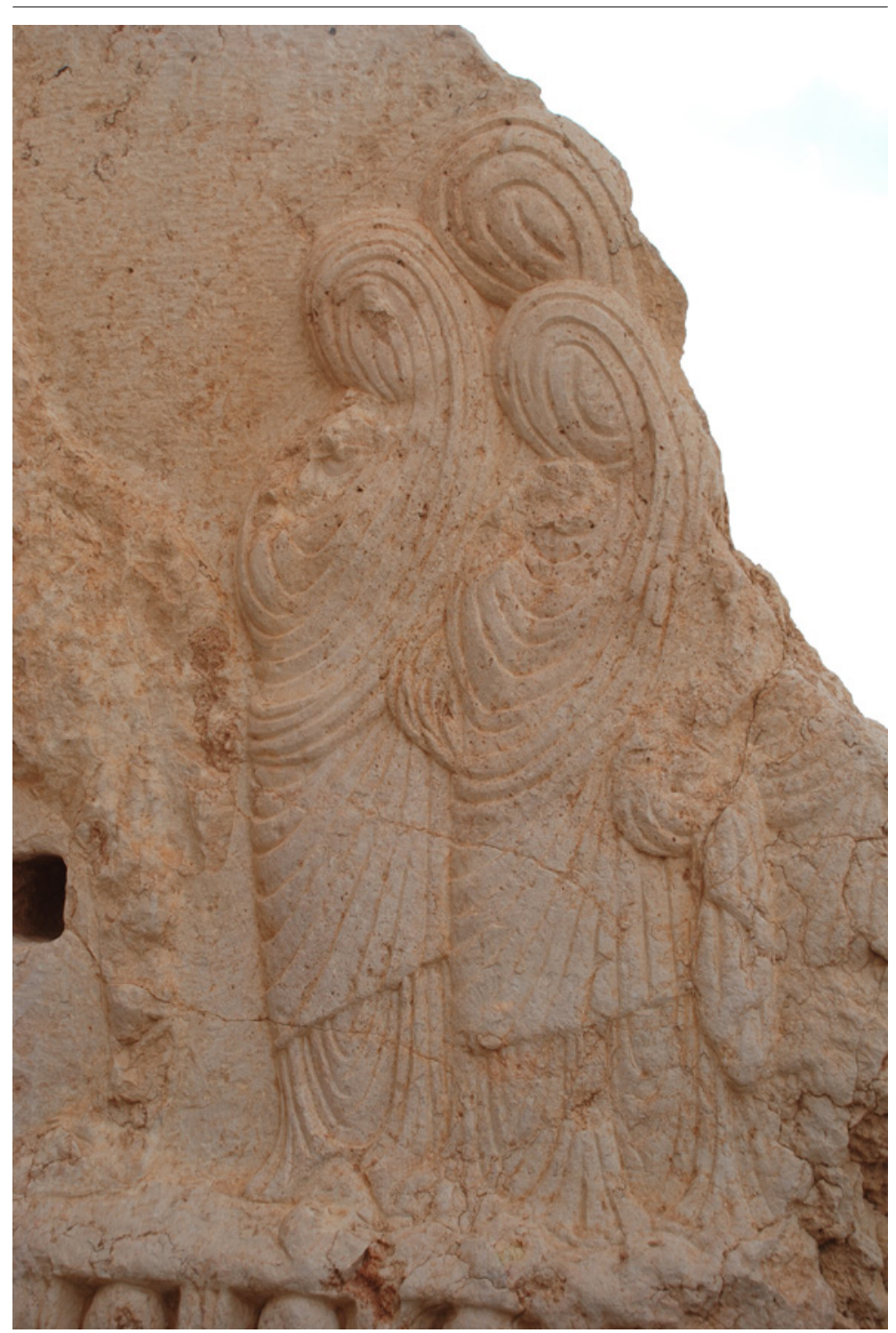

Figure 5 Processional relief in front of the entrance of the Bel-temple in Palmyra in 2011 (photo H.D. Galter 2011) 
Arabia's heathen females will be your judges, who cover not only the head, but the face also, so entirely (non caput sed faciem quoque ita totam), that they are content, with one eye free (uno oculo liberato), to enjoy rather half the light than to prostitute the entire face. A female would rather see than be seen. (XVII, 4) ${ }^{77}$

This passage refers to customs of veiling in pre-Islamic Arab societies that could be seen on the processional relief from the Bel-temple in Palmyra [fig. 5] until 2014, when the "Islamic State" blew up the temple.

\section{Hair as an Erotic Symbol in the Ancient Near East}

Our hair has always been a major element in the formation of first impressions and self-representation, respectively. It documents physical and mental conditions, social aspirations, well-being, or illnesses. It leaves a lasting impression on others and influences judgments about our character or health-condition. As a result, our hair forms an essential and sometimes highly emotionally charged element of nonverbal communication..$^{78}$ Our hair is perhaps the most powerful symbol of individual and group identity. It is physical and therefore extremely personal. At the same time, as an element of communication it is public rather than private. It conveys information about age, status, social class or even the gender of the persons involved..$^{79}$

In 1958, Edmund Leach introduced a comparative perspective to the sociological discussion of the hair by giving a synthesis between anthropological and psychological data. After reviewing evidence from Hinduism in India and Buddhism in Sri Lanka, Leach concluded that long hair symbolises unrestrained sexuality, while short hair, tightly bound hair, or a partially shaved head indicates restricted sexuality while close shaven heads act as a sign of celibacy. ${ }^{80}$ This view was contradicted by Christopher Hallpike, who used examples from the Bible and from contemporary societies. He suggested instead that trimmed hair indicates social control and uncut hair symbolises being outside society. ${ }^{81}$ Other anthropologists have studied hair sym-

\footnotetext{
77 Tertullian, De virginibus velandis. http://www.tertullian.org/anf/anf@4/anf๑4๑9.htm\#P671_166987.

78 Bergler 2003; Hirschman 2002.

79 Pergament 1999, 46-8.

80 Leach 1958.

81 Hallpike 1969. For the further history of the discussion see Synnott 1987, 404-10.
} 
bolism in various cultures.$^{82}$ Anthony Synnott has advanced a theory of opposites: opposite sexes have opposite hair and opposite ideologies have opposite hair as well. ${ }^{83}$

Hair as a marker for cultural codes can be traced back to Antiquity. In men, long hair represented strength and virility. In the biblical account of Samson and Delilah (Judges 16) the hero was given extraordinary strength but lost it when his long hair was cut. Being combed was seen as a sign of trust, intimacy, and love. Male Sikhs in India still find it indecent to expose their hair in public today. ${ }^{84}$

Women's hair was regarded as a special sign of beauty and often attributed seductive power. The beauty of the Greek goddess Aphrodite was especially indicated by the splendour of her hair. The power of hair as a sexual symbol is further documented in medieval love poetry. ${ }^{85} \mathrm{~A}$ contemporary advisor on dress for women argues in the same way: "My thinking was that a girl just isn't a girl without her hair". ${ }^{86}$

All this is in perfect accordance with Ancient Near Eastern perceptions of sex appeal and female attraction. Both Mesopotamian languages - Sumerian and Akkadian - use words for "abundance" and "opulence" to describe female beauty.

The Sumerian word hili means "(to be) luxuriant", "(to have) pleasure", "sex appeal". ${ }^{87}$ It is predominantly attested in literature texts written down at the beginning of the second millennium BCE, for instance in Inana and Enki, where "feminine attraction" (hi-li nam-munus-e-ne) is mentioned among the "me" of Inana. ${ }^{88}$ In the royal hymns of Šulgi of Ur, hili is also associated with Inana. She is called "attraction of all mankind" (hi-li sag-gig $\left.g_{2}-g a\right)^{89}$ and "attraction of heaven and earth" (hi-li an-ki-a). ${ }^{90}$ Hili is attributed to women and men alike. Šulgi for instance is chosen by Inana for his attractiveness. ${ }^{91} \mathrm{Hili}$ is further said of jewellery, clothing, furniture, fruits and trees..$^{92}$ The compound verbs hili-kar and hili-teg $\hat{g}_{3}$ that occur especially in Sumerian love songs are used for "to love", "to be fond of", "to be attracted to". ${ }^{93}$

82 Derrett 1973; Hershman 1974; Houlbert 1979; for more literature see Synnott 1987, 382

83 Synnott 1987; also Synnott 2016, 103-27.

84 Synnott 1987, 384-6; Pergament 1999, 43-8.

85 Sleeman 1981, 322-32; Pergament 1999, 45-6.

86 Hemingway 1979, 143; see also Synnott 1987, 383-6 and compare Banks 2000.

87 PSD sub hili.

88 ETCSL 1.3.1: Segment I 95; see Stol 2004.

89 ETCSL 2.4.2.24 (Šulgi X): 43.

90 ETCSL 2.4.2.01 (Šulgi A): 82.

91 ETCSL 2.3.2.01 (Šulgi A): 15.

92 Leick 1994, 74, but compare Jacobsen 1973, 207-8 and Wilcke 1975, 312.

93 Sefati 1998, 159-60. 
The Akkadian equivalent to hili is kuzbu. The Chicago Assyrian Dictionary ${ }^{94}$ lists "luxuriance, abundance, attractiveness, charm, sexual vigor" as translations. Again, it could be used as an attribute for women and men alike.

But kuzbu could also refer to the rich adornments of buildings, the abundance of water or the luxuriance of vegetation in a garden. The Assyrian king Sennacherib for example adorned the garden of his akitu-temple at Ashur with luxuriant plantations (musarê kuzbi). ${ }^{95}$

The Akkadian adjective šamhu had similar meanings: "luxuriant", "lush", "prosperous". ${ }^{96}$ It was used to describe canebrakes, pastures, populations, and individuals. It appears in male and female personal names and its female form šamhatu was one denotation for a prostitute in Akkadian. Both forms derived from the verb šamāhu meaning "to grow thickly", to flourish", "to attain extraordinary beauty". ${ }^{97}$

In 1994 Gwendolyn Leick wrote the book about sex and eroticism in Mesopotamia. Surprisingly enough, in the chapter on femininity and eroticism in Sumerian literature ${ }^{98}$ she does not say a word about what made a woman, especially the goddess Inana, whom she calls "the most feminine of goddesses", 99 sexually attractive. She discusses the words hili and kuzbu but comes to the conclusion that the available data forms only inconclusive evidence for the semantic range of the lexemes. ${ }^{100}$

Mesopotamian texts did not praise the luxuriance of the female body, as for instance medieval Arab and Turkish tales do, but the luxuriance of the hair. ${ }^{101}$ At the beginning of "Enki and the World Order" it is stated that Enki's word bestows vigour in the heart of the young man and attractiveness (hili) on the head of young woman. ${ }^{102}$ Andrew George published a list of shrines in the $E_{2}$-rab-ri-ri, the temple of Madānu in the temple complex of Esaĝil in Babylon, in which the shrine of the divine hairdressers of Zarpanitum is called $E_{2}$-hi-li-sag ${ }_{10}$-ga "Shrine of beautiful attractiveness"). ${ }^{103}$ Rainer Boehmer clearly realised that the goddess on the Uruk-vase has the same hairstyle as her female attendants but is highlighted by the luxuri-

CAD K, 614-15.

Grayson, Novotny 2014, 248 (Sennacherib 168): 35.

CAD Š1, 312.

CAD Š1, 288-90.

Leick 1994, 55-63.

Leick 1994, 66.

Leick 1994, 74 and 184.

Börker-Klähn 1972, 2-5; Stol 2016, 52.

ETCSL 1.1.3: 32-34.

George 1992, 106: 17' and see the discussion on pages 412-13. 
Hannes D. Galter

Veil and Headscarf: Five Aspects of a Cultural Phenomenon

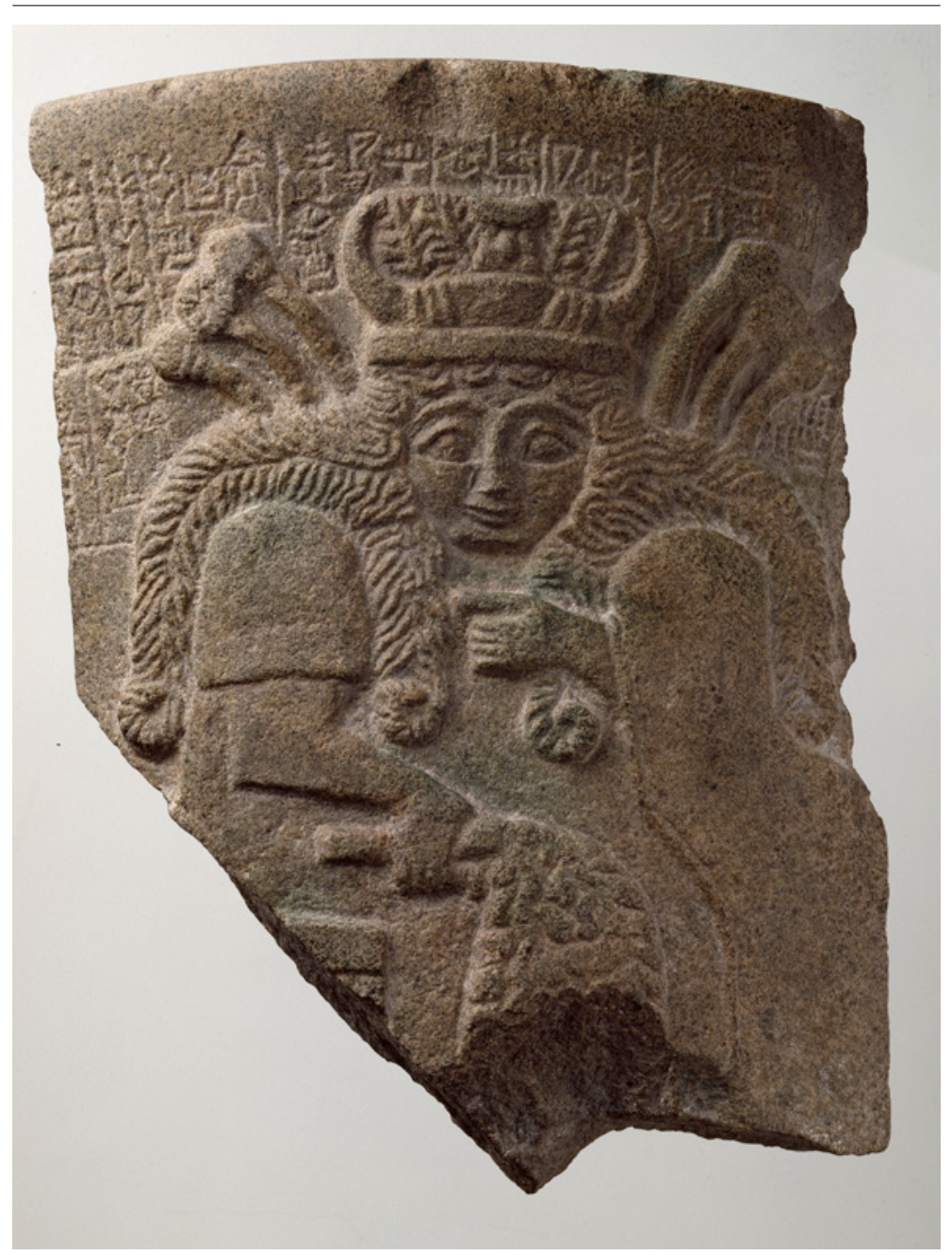

Figure 6 Vase fragment from Lagash, Vorderasiatisches Museum, Berlin, VA 07248 (photo bpk/Vorderasiatisches Museum, SMB / Olaf M.Teßmer) 
ance of her hair. ${ }^{104}$ Another example is the fragment of a stone vase from Lagash around 2300 BCE now housed in the Vorderasiatisches Museum in Berlin [fig. 6] which depicts the goddess Nisaba with long hairlocks.

It shows the goddess Nisaba with long and exuberantly growing locks of hair. All other attributes of the deity, the ears of barley at her crown and the bunch of dates in her hand connect her with a flowering vegetation. ${ }^{105}$ And the use of kuzbu in connection with a garden, as mentioned above, is comparable to the garden metaphors in Sumerian love songs. ${ }^{106}$ A passage from a hymn to Šu-Sîn, king of Ur, attributed to his wife Kubatum, reads:

My hair is lettuce, well watered. It is the sprout of a lettuce, well watered. Its tangled coils [?] have been tightened. My nursemaid has ...... them high and made my hair stag-like. She has tightened its tiny hairgrips and brought order to my charms; my charms, my hair, the lettuce, is the fairest of plants. ${ }^{107}$

Marten Stol compared this orchard metaphor with the golden headgear of queen Puabi resembling leaves and flowers, which was found by Leonard Wooley in the royal graveyard in Ur. ${ }^{108}$ The hair of the beloved woman is a common topic in the Inana-Dumuzi love songs. Inana is fond of her long dangling hair and arranges it in a tight hairdo when she goes to war:

I have washed my dangling hair, I have tested my weapons that make his reign propitious. I have straightened my tousled head of hair, I have tightened my loosened hairgrips, and let my hair fall down the back of my neck. ${ }^{109}$

On the other hand, the loosening of her hair indicates a time of sexual encounters:

She lets down her hair [siki] which was combed up..$^{110}$

105 Compare the stele from Lagash given in Asher-Greve 2006, 60, fig. 8 and several other images in that article. See also Otto 2016, 114-16.

106 Compare Lambert 1987, 28-31; Leick 1994, 71 and 120-4; Stol 2016, 52-3.

107 ETCSL 2.4.4.3: 1-8.

108 Stol 2016, 49.

109 ETCSL 4.08.03: 11-15.

110 ETCSL 4.08.31: 5. 
Let me loosen your hairgrip on the holy and luxuriant couch. ${ }^{111}$

All images of sexual intercourse presented by Gwendolyn Leick show the women with loose hair. ${ }^{112}$ This visual signal has survived the centuries and is still part of the visual language of modern films. In one case the preparations for Inana's date with Dumuzi include the adornment of her hair with erotic pendants:

She chooses the golden genitals and puts them on the hair of her head. ${ }^{113}$

And again, the garden metaphor is used in the same way as in the love song for Šu-Sîn:

May my sheep eat my unkempt long hair, my plants, my esparto grass. ${ }^{114}$

The hair of the male lover is similarly praised:

My one distinguished by a shock of hair [suhur], my one distinguished by a shock of hair! My sweet, my one distinguished by a shock of hair! My one distinguished by a shock of hair like a palm tree! My shaggy-necked one like a tamarisk, my one distinguished by a shock of hair! My man distinguished in the assembly by your shock of hair! $!^{115}$

Apart from the denotations of luxuriance and sex appeal the Sumerian hili could also designate a wig. ${ }^{116}$ This use is found in Sumerian literary texts and in Ur III-documents from the end of the third millennium BCE ${ }^{117}$ A ritual text from Seleucid Uruk (W 18728) describes the religious costumes of various groups of the clergy. The royal costume for this ritual consisted of a tunic and at least two robes, ample jewellery and an "Inana wig" (hili dinana). ${ }^{118}$ Jutta Börker-Klähn assumed that the famous marble head from Uruk too had originally

111 ETCSL 4.08.08: 21.

112 Leick 1994, pl. 1-10.

113 ETCSL 4.08.20: 14.

114 ETCSL 4.08.23: 31-32.

115 ETCSL 4.08.25: 34-38.

116 Börker-Klähn 1972, 5-6; Stol 2004, 2016, 50-2.

117 See Attinger, Krebernik 2005, 66 and the attestations listed in the PSD sub hili.

118 Falkenstein 1959, 40-1: rev. 11'. 


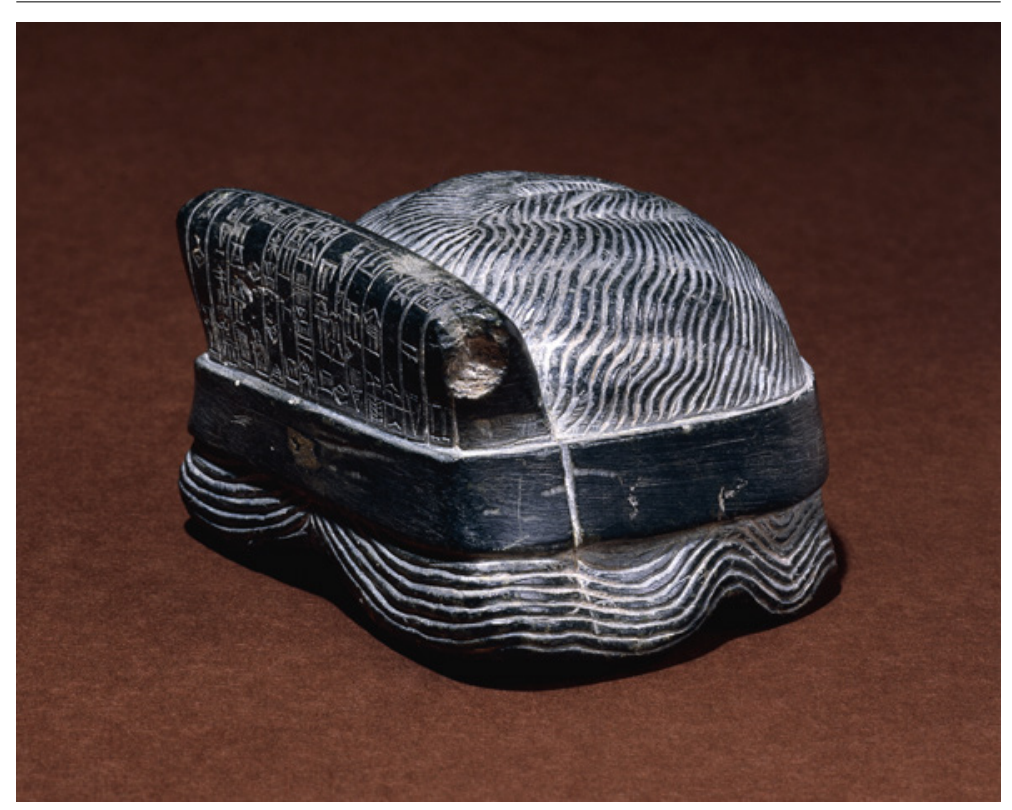

Figure 7 Votive wig from Ur III period (photo $\odot$ The Trustees of the British Museum)

worn a ceremonial wig. ${ }^{119}$ Gebhard Selz argued in the same way supposing that wigs, artificial beards, and perhaps masks might testify to changes of ceremonial roles and sometimes might even be connected to a temporary divine status. ${ }^{120}$

At the beginning of "Inana's descent to the netherworld" the goddess adorns herself and puts a wig (hili) and a turban ( tug $_{2}$-šu-gur-ra) on her head. ${ }^{121}$ A similar description but without the mentioning of hi$l i$ is found at the beginning of "Inana and Enki". ${ }^{122}$ Sam Kramer challenged the interpretation of hili as a wig in his treatment of "Inana's descent to the netherworld" because the line says that Inana put the hili on her forehead, which seemed improbable to him. He translated "locks (of hair)" instead, based on a suggestion by Benno Landsberger. ${ }^{123}$ On the other hand Thorkild Jacobsen understood the lines as if Inana put a desert-headscarf, a kefia (tug ${ }_{2}$ ) and aghal (šu-gur$r a$ ), on her head and held a wig (hili) in her hand in order to change 
in the palace of the netherworld. ${ }^{124}$ But the headdress was the first thing taken from her when entering the first gate of the netherworld. ${ }^{125}$

The model of such a wig from Southern Iraq was purchased by the British Museum (BM 91075) [fig. 7] in 1878. It is made of grey chlorite $(8.5 \times 8 \times 4.5 \mathrm{~cm})$ and carries a votive inscription by Bau-ninam an official of the king Šulgi of Ur (2094-2047 BCE)

For the goddess Lamma, his lady, for the life of Šulgi, mighty man, king of Ur, Bau-ninam, the cup-bearer of Ur-Ningirsu, beloved enpriest of the goddess Nanše, fashioned her ladylike wig [hili nammunus-ka-ni] for her. ${ }^{126}$

Two wigs from the Early Dynastic palace G in Ebla, made of green steatite and beige limestone respectively, were housed in the museum of Aleppo before the civil war. ${ }^{127}$ Others were found in Uruk, Ur, Girsu, Mari, Sippar, and Ashur. ${ }^{128}$ A model of a male royal wig with carved ears and an elaborate hairstyle from the Early Dynastic III period is also housed in the British Museum (1994,0620.1). It is also made from stone, shows no inscription, and is partially restored. ${ }^{129}$

Similar praises of the hair of the beloved woman can be found in the Hebrew Song of Songs:

Your hair is like a flock of goats, moving down the slopes of Gilead. $(4: 1 ; 6: 5, \mathrm{NASB})$

But the hair of the male lover is similarly praised:

His head is the finest gold; his locks are wavy, black as a raven. (5:11, NASB)

It is stated clearly that the flowing locks and tresses of the beloved woman are the means by which the lover is entrapped:

Your head crowns you like Carmel, and your flowing locks are like purple; a king is held captive in the tresses. $(7: 5, \mathrm{NASB})^{130}$

126 Frayne 1997, 215-16 (1.2.2030). Note the translation by Marten Stol (2016, 49): "hili of her femininity".

127 Kohlmeyer, Strommenger 1982, 81, nos. 73 and 74; Stol 2016, 50, fig. 8.

128 Börker-Klähn 1972, 5-6.

129 Moorey 1996.

130 The word "tresses" is unclear. 
When the rabbis defined the feminine hair as sexually attractive in the Talmud (Berakhot 24a), and prohibited men from praying in sight of a woman's hair, they based their decision on the verse mentioned above: "Your hair is like a flock of goats", which in their opinion proofed the sensual nature of the hair.

The veiling of women is mentioned several times in the Song of Songs. It is used to draw attention to other aspects of feminine beauty: the soft pink colour of her temples (4:3) or the shape and colour of her eyes, which became another major aspect of beauty in the Old Testament: ${ }^{131}$

How beautiful you are, my love, how very beautiful! Your eyes are doves behind your veil. $(4: 1, \mathrm{NASB})^{132}$

Athalya Brenner has summarised the criteria for feminine beauty in the Song of Songs mainly based on its chapter 4 . The female lover has eyes like doves, long and flowing hair, symmetrical white teeth, red lips, a perfect and a symmetrical appearance. Her breasts for instance resemble twin gazelles. The rest of the body is described by a garden metaphor focusing on the fragrance of the beloved. ${ }^{133}$ The mentioning of the hair and jewellery and the fact that the Song of Songs uses the same garden similes as the Sumerian love songs once more proofs the fact that the text is part of a larger Ancient Near Eastern tradition of love poetry. ${ }^{134}$

In early Christian tradition, the uncovered hair of women still had the connotation of sensual provocation. ${ }^{135}$ Thus, Mary Magdalene was usually depicted with open long hair symbolising her former state as a sinner. This conception of her character as a repentant prostitute goes back to pope Gregory I (c. 540-604 CE) and was based on an erroneous merging of chapters 7 and 8 in the Gospel of Luke. Eve is often depicted in the same way. Capital $\mathrm{C}$ in the central apse of the basilica of Notre-Dame du Port in Clermont-Ferrand shows the disobedience of Eve in opposition to the obedience of Mary on capital B. In this relief the angel drags the temptress Eve out of paradise by her long hair. ${ }^{136}$ John Milton in Paradise Lost (1667) reinforced the image of Eve as a temptation to Adam by describing her hair and, again, using the garden metaphor: 
Hannes D. Galter

Veil and Headscarf: Five Aspects of a Cultural Phenomenon
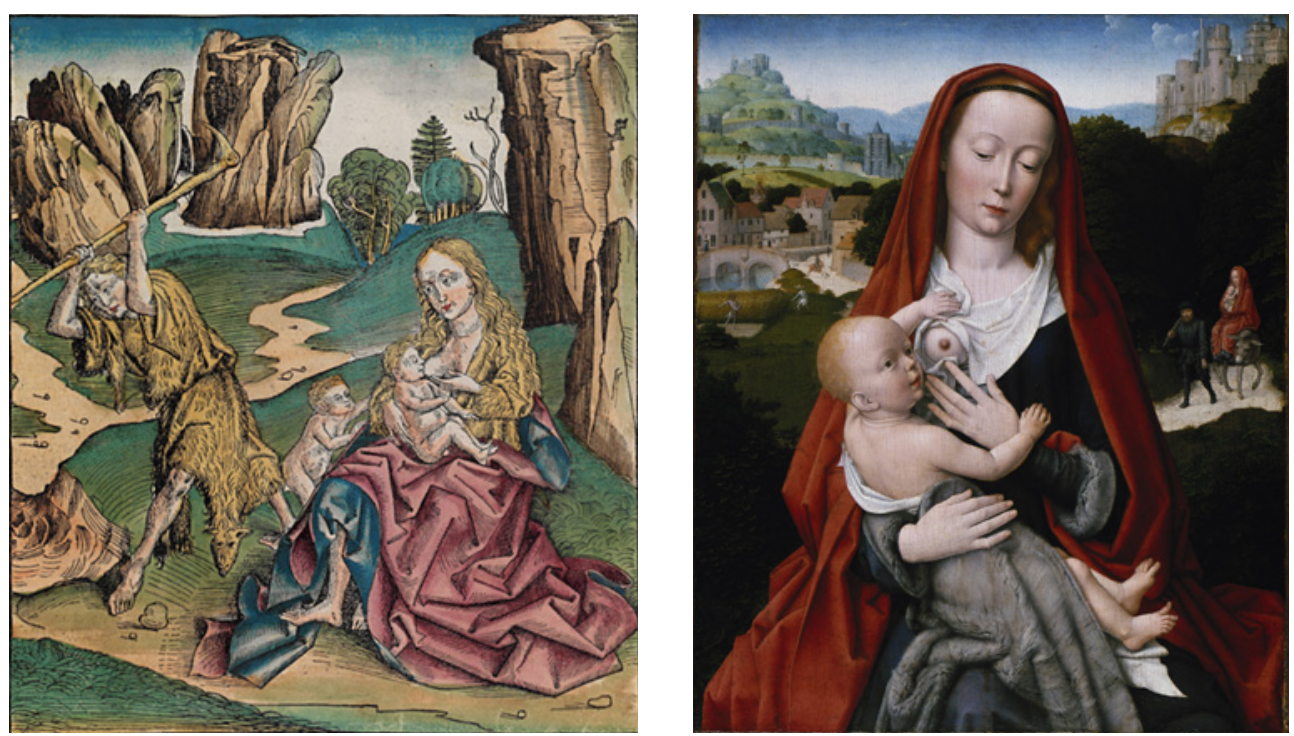

Figure 8 Adam and Eve, Schedelsche Weltchronik, c. 1493. https://www.apostolische-geschichte.de/wiki/ images/Adam_und_eva.png

Figure 9 Gerard David (c. 1450-1523): Madonna and Child, Gemäldegalerie der Staatlichen Museen in Berlin (photo bpk / Gemäldegalerie, SMB / Jörg P. Anders)

She, as a veil down to the slender waist, her unadorned golden tresses wore dishevelled, but in wanton ringlets waved as the vine curls her tendrils - which implied subjection, but required with gentle sway, and by her yielded, by him best received - yielded, with coy submission, modest pride, and sweet, reluctant, amorous delay. ${ }^{137}$

The following juxtaposition of Eve and Mary in comparable poses documents clearly that the dichotomies decent/indecent and honourable/dishonourable were established by means of headgear in early Christianity [figs 8-9]. ${ }^{138}$

Since the hair was regarded as the most beautiful adornment of a woman, the covering of the hair of the honourable, married woman with a bonnet, headscarf, or veil in public was common practice in

138 Kraus 1982; Krieger 2012, 34 and 53; Wolin 2014; compare Kobler 1970. 
Europe during the Middle Ages. ${ }^{139}$ In German we still have the phrase "unter die Haube (bonnet) kommen" for getting married.

On the other hand, the removal of the bonnet, headscarf, or veil and the loosening of the hair had a very strong sexual connotation. Nineteenth-century authors like Pierre Louys or Oscar Wilde restored this connotation. In his 1891-92 play Salomé Wilde introduced the "Dance of the Seven Veils", which received worldwide fame through Richard Strauss's opera Salome (1905). ${ }^{140}$ This dance is pure fantasy and has no historical role models, neither in the Bible nor in the Ancient Near East. Wilde's concept of it is believed to be derived from popular performances of veil dances especially at the world exhibitions in Paris (1889) and Chicago (1893). The dancers "Little Egypt" and Loïe Fuller were especially associated with veil dances. Influenced by the controversies and scandals caused by these performances and partly also by Wilde's play a new form of mass entertainment emerged in the music halls including numerous shows of female performers who engaged in various forms of undressing. With and without biblical references the "Dance of the Seven Veils" became a general attraction.

Toni Bentley compared the dance of the seven veils with the successive unclothing of Inana/Ištar in the Mesopotamian tale of her descent to the netherworld. ${ }^{141}$ As we have already seen, the goddess had to remove all her jewellery and garments, one by one, at the seven gates of the netherworld. Naked and stripped of all her power she had to submit to the rules of the netherworld. When she finally is revived through a trick of the god of wisdom Enki/Ea, she is given back all the symbols of majesty and power that were taken from her. Unlike modern striptease shows, which are supposed to create some erotic feelings, the unclothing of Inana/Ištar had the opposite effect. In the Akkadian version ${ }^{142}$ it resulted in the total termination of all sexual activity on earth. The Sumerian text is suspiciously silent about the consequences.

139 See Margit Stadlober in the present volume. For female head coverings in early Christian art compare Koslin 2008 and Dellemann 2013, 102-11.

140 Caddy 2005; Kultermann 2006; Malik 2008.

141 Bentley 2002, 32.

142 Foster 1996, 402-9. 


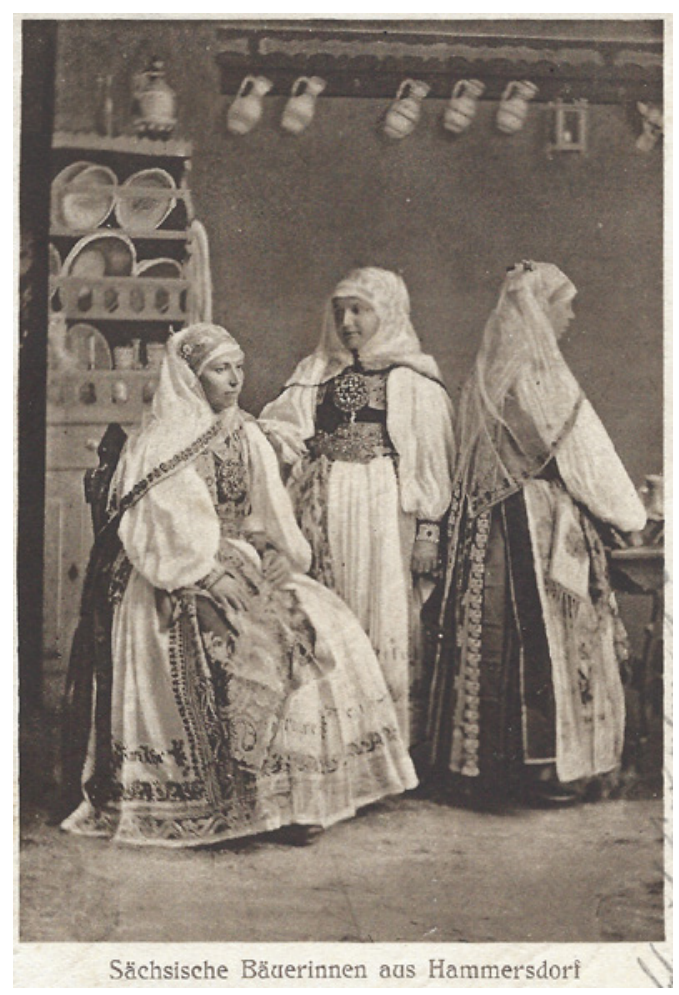

\section{$5 \quad$ Headscarves and Veils in the Traditional Costume of Transylvania}

Within European traditional costumes, in particular the festive costumes, headscarves and veils are still an integral part of clothing. For instance, elements of the Southern German dress of the 14th and 15th centuries have survived in Transylvania until today. ${ }^{143}$ Transylvania has had an eventful history and underwent many political, social, and cultural changes. Located at the southeastern fringes of Europe and close to the border of the Ottoman Empire, it was subjected to countless military operations and changing sovereignties. Different ethnic groups, such as Germans, Hungarians, and Romanians, but also Székelys, Turks, and Roma have lived side by side and although

143 I have chosen this example because of the Transylvanian-Saxon background of my family. 
each group maintained its own traditions and costumes, they influenced each other profoundly. ${ }^{144}$

The Transylvanian Saxons, who migrated from the area between the Rhine and the Moselle to the Carpathian highlands in today's Romania in the 12th century, have preserved their traditional costumes for centuries [fig. 10]. ${ }^{145}$ There have been changes over time, new elements were added, others have been abandoned. But thanks to the strong sense of tradition of the Transylvanian Saxons, a unique landscape of traditional costumes was created, blending German, Hungarian, Ottoman, and Austrian elements. Every region, every town, and every village had its own distinctive costume, by which the residents were recognised.

There was a clear difference between rural and urban costumes. Whereas the rural dress had to be primarily functional and durable, the urban fashion mirrored the social hierarchy within the towns. It defined the position of a person within society and consisted of significantly more accessories and jewellery. The firm social division into generations and genders as codified in the neighbourhood rules was particularly evident in the public space. There was a fixed seating arrangement in church with the women sitting in the main nave and the men at both sides. In that same strictness people had to pay attention to the specifications of their costumes, which marked origin, status, and age through traditional 'recognition marks', which were strictly adhered to. A married woman was dressed differently than a young girl or a confirmand. The costume of older women also differed from younger women in the colour of their garments and in the headgear. All social relations and interactions were controlled by the neighbourhood too. ${ }^{146}$

The Transylvanian folk costume was primarily a festive costume. Wearing it was regarded as a declaration of one's commitment to the Saxon community and the Lutheran Church. ${ }^{147}$ Special occasions, such as church attendance, confirmation, wedding, or the "Kronenfest" at St. Peter and St. Paul's Day (29 June) demanded the wearing of the traditional costume. The dress was well-tailored and rich in jewellery and embroideries in primary colours, such as red, blue, yellow, or black, the favourite motifs being floral ones with each of them carrying its own specific symbolism. The manufacture of the

144 Takács 2017. For the following see Bielz 1965; Treiber-Netolicka 1968; Scola, Bretz-Schwarzenbacher, Schiel 1987; Schmidt, Förderreuther 2011; compare Waltraud Fleischer: Siebenbürgisch-sächsische Tracht: https://www.siebenbuerger.de/portal/ daten/dokumente/50-jahre-lg-baden-wuerttemberg/sachsen/10.htm.

145 Orend 1958; Davis 2010, 200.

146 Schubert 1980, 44-5; Benesch 2013, 185.

147 Römer 1922; Davis 2010, 202-4. 


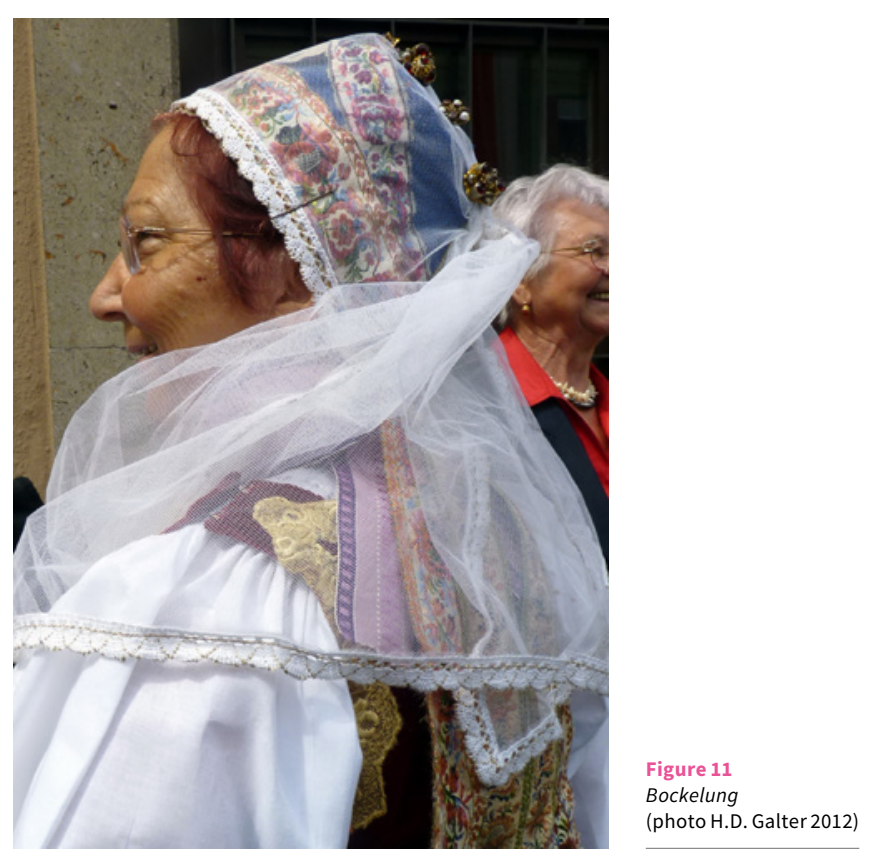

dress was mainly done by the women at home. This was part of the long-established gender divisions within the family.

Until the middle of the 16th century, the costumes of the urban citizens were based on the fashions of European cities especially in Flanders and Luxembourg. Garments, such as the Krause Mantel, a wrinkled mantle of black fur, the Heftel, a large pendant that evolved from the Germanic round fibula, the Spangengürtel, a girdle with metal embossing, or the Borten, a cylindrical headdress about $15 \mathrm{~cm}$ high, coated with black velvet and with colourful ribbons made from silk, embroidered velvet, or gold hanging on the back are from this period. ${ }^{148}$ The Borten was worn by girls after their confirmation until their marriage. It evolved from the medieval hair band (Middle High German borte) of young girls in German territories. ${ }^{149}$ The veil of the married woman (Schlodderdeach, Schlejerdaoch) also corresponds to the female headgear in Flanders in the 15th century [fig. 11]. ${ }^{150}$

After the defeat of the Hungarian army by the Ottoman forces at Mohács in 1526, Hungary and Transylvania came under Otto- 
man rule. In the following period, oriental influences in traditional costumes were predominant. They reached Transylvania mainly through Hungarian or Polish mediation and mainly concerned the men's dress. Although the covering of the head of a married woman with a white veil looks suspiciously Ottoman, it is part of a much older tradition that had its roots in the southern parts of Germany. ${ }^{151}$

With the annexation of Transylvania by the Habsburg Empire in 1711, economic and cultural ties with Europe were revived. Once again, the western influences of fashion prevailed in the traditional costumes. In the following period, the rural population took over numerous elements from the urban costume but adapted them to their specific region and preference. By the end of the 18th century, wealthy urban families began to adopt the modern fashions that they encountered, especially in Vienna. It was significantly cheaper to purchase ready-made clothing than to manufacture it at home. However, traditional costumes retained their public role as festive wear. They were reserved for special occasions such as festivals or church ceremonies. ${ }^{152}$

Little girls and schoolgirls wore colourfully embroidered and flounced bonnets, confirmed girls either tied a hairband around their heads or put on the Borten to go to church. On her wedding day, the bride wore the Borten for the last time. ${ }^{153}$

Married women had to cover their hair completely, either with a bonnet or a cloth. Black velvet bonnets, colourfully embroidered and often decorated with pearls, were characteristic of Northern Transylvania. The bonnets of young women had silk embroideries in pink and red, the bonnets of older women showed embroidered flowers in yellow, purple, and blue. In Southern Transylvania, white or black bonnets were worn, and in Burzenland, black velvet ones embroidered with gold. ${ }^{154}$

When going to church the women artfully laid a veil of white tulle over their bonnets or used a white linen or cotton headscarf knotted under the chin (Knäpdich). ${ }^{155}$ In some regions (e.g. Mediasch or Katzendorf) cloths from tulle were prohibited. ${ }^{156}$ An old woman in Honigberg told me that she would never go to church without a headscarf, because she would not be properly dressed.

The preparations for veiling (Bockelung or Schleijern) were very time-consuming and could often not be carried out by one person

153 Schmidt, Förderreuther 2011, 75.

154 Schmidt, Förderreuther 2011, 77-82.

155 Schmidt, Förderreuther 2011, 70-2.

156 Schmidt, Förderreuther 2011, 71. 


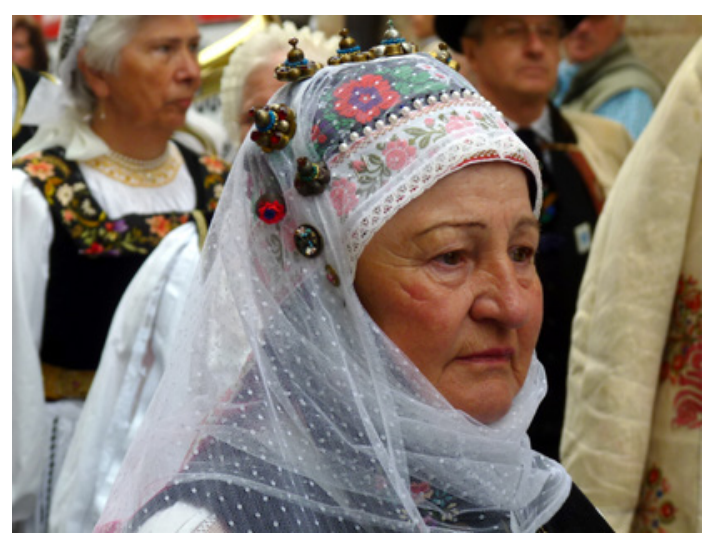

alone. ${ }^{157}$ The woman's hair had to be braided into two plaits, which were placed around the back of the head and attached with hairpins. A small cloth could also be used as a substitute. A bonnet and a cushion were placed on it. Then, a ribbon of wool was wrapped around the head so that no hair would be visible anymore.

Over this ribbon several others made of black, white, or colourful silk were placed and fastened at the neck with needles. They usually fell overlapping down to the hem of the skirt.

Finally, a white, black, or dark blue veil was placed around the head [fig. 12]. ${ }^{158}$ It was about one and a half meter long and up to 60 $\mathrm{cm}$ wide, made of tulle lace, linen batiste, or silk, and often decorated with woven flower patterns. The women wrapped it from left to right and attached it with 4 to 12 buckle needles. Usually these needles were very valuable and had been in family possession for a long time. The more needles were used, the more splendid was the impression the woman left behind. The centre of the head could also be decorated with a brooch. Afterwards, the veil was artfully draped around the chin and the back of the head.

Type and colour of the veil were determined by the age and status of the woman and differed from region to region. For example, in Stolzenburg young married women wore a small yellow veil, in Rode a black or dark blue one. After the birth of the first child at the lat-

157 Scola, Bretz-Schwarzenbacher, Schiel 1987, 18-19; Schmidt, Förderreuther 2011, 73-5.

158 Kanz, Rothbächer 2008, 35-46; compare the instructions for veiling: http://hogrode.de/wp-content/uploads/2018/03/Dokumentation-Festbockelung.pdf and http://hogrode.de/wp-content/uploads/2018/03/Dokumentation-wei\%C3\%9FeBockelung.pdf. 


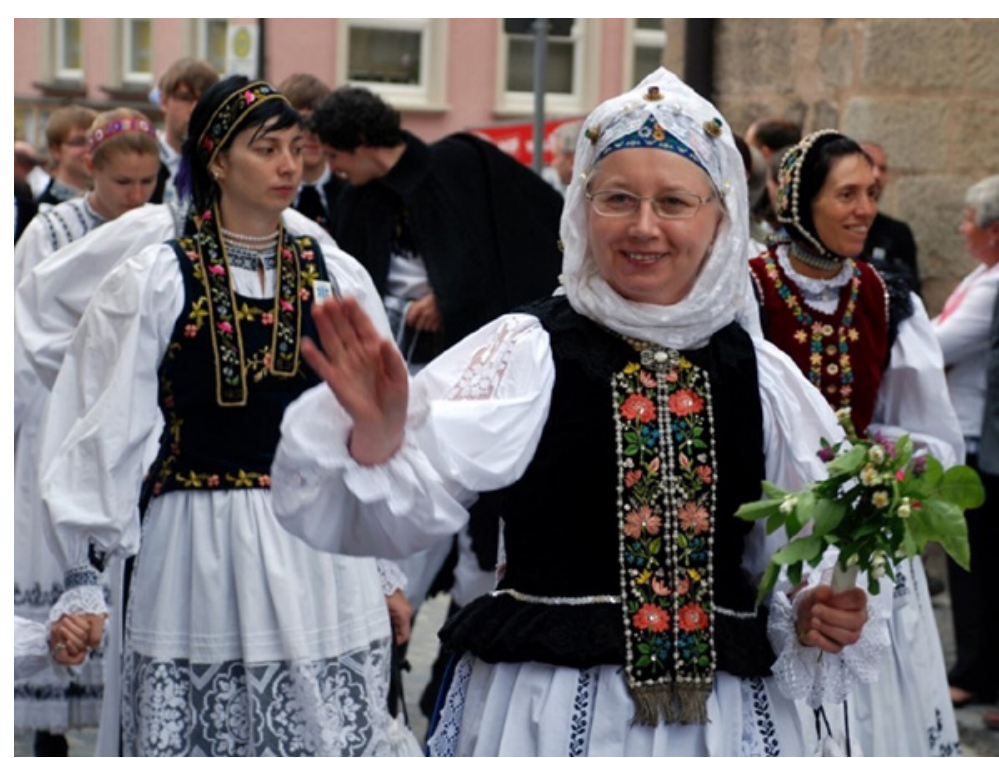

Figure 13 Parade at the gathering of Transylvanian Saxons in Dinkelsbühl (photo H.D. Galter 2012)

est, all married women used a white veil. At a later age, the headdress became much simpler. Women of middle age usually wore white silk headscarves, older women shawls made of linen with elaborate flower embroidery.

The customs for covering the head have changed, they have become looser. Before World War II all married women wore headscarves every Sunday on their way to church. After the war, the use of the headscarf declined. Nevertheless, during the 70s there were still many women who owned a festive costume and wore it on Sundays. With the fall of the Iron Curtain and the large-scale emigration of Transylvanian Saxons to Germany and Austria the use of the costume in Transylvania almost vanished.

But even now, 75 years after the Transylvanian Saxons had to leave their homes in the turmoil of the Second World War, they continue to cultivate their traditional customs in Germany, Austria, Canada, or the USA. Women in the Transylvanian associations still manufacture the elaborate headgears and wear them during festivals and parades [fig. 13].

In other parts of Europe, the veil gradually disappeared from traditional fashion. It was only preserved in the form of the bridal veil or as part of the habits of Christian nuns.

At the beginning of the 19th century, the machine-made tulle was invented and used for fashionable veils, such as the hat veil 
(Hutschleier) of the Biedermeier, which was also used in riding hats, or the loose "Iphigenia-veil", which spread from Spain through the whole of Europe. From England came the veil scarf that was especially worn by women when driving. Such a veil scarf, flittering in the wind and caught in the spokes of the wheels of her Bugatti, caused the fatal accident of Isadora Duncan on 14 September 1927.

\section{The Veil of Mystery}

In European history, the veil received additional meanings. Apart from the connotations of protection and sheltered life, the sense of hiding, concealment, and mystification were added. In German we still use the expression etwas verschleiern (to veil something) to describe the concealment of a fact that we do not want others to perceive. Platonic and Neoplatonic philosophy included the concept of the veiled truth, which could only be hinted at in allegories and metaphors. ${ }^{159}$

In chapter 9 of his work on Isis and Osiris (De Iside et Osiride) Plutarch (c. 45-125 CE) deals with mystery and secret in Egyptian religion. He gives three examples for the manifestation of these concepts: the figures of the sphinx, the name of the god Amun ("the hidden one") and the veiled statue of a goddess in the Egyptian city of Sais. According to the Greek writer, the statue represented the goddess Isis/Athena and bore the inscription "I am all that has been and is and shall be; and no mortal has ever lifted my garment". ${ }^{160}$ The first part of this inscription already identifies Isis as a preeminent and universal goddess. For this reason she was equated with Athena and Neith of Sais. ${ }^{161}$ The second part either points at the virginity of the goddess or, as suggested by Jan Assmann, represents a mistranslation of the original Egyptian expression "There is nobody except me", again proclaiming the uniqueness of Isis. ${ }^{162}$ Plutarch uses the Greek word peplos ( $\pi \dot{\varepsilon} \pi \lambda \circ \varsigma$, "mantle") for the garment indicating the majesty and remoteness of the goddess. It might also relate to Neith's function as goddess of weaving. ${ }^{163}$

When the Neoplatonist philosopher Proclus (412-485 CE) wrote a commentary on Plato's Timaeus dialogue, he mentioned the same inscription in book I, but uses the Greek word chiton ( $\chi \imath \tau \omega$, " "undergarment"), thus assigning a clear sexual meaning to the act of un-

161 Assmann 1999b, 12-13.

162 Assmann 1999a, 60.

163 Hani 1976, 244-5; Assmann 1999b, 51-3; 2000, 35-42. 
veiling. ${ }^{164}$ Although the mystery cult of Isis was prohibited in $391 \mathrm{CE}$, its ideas survived in the gnostic and hermetic literature and in European esoteric traditions. ${ }^{165}$ Isis was often combined with Artemis of Ephesus and depicted as a goddess with multiple breasts covered by a veil or already unveiled. During the 15th century, a revival of Neoplatonic thinking started, and nudity was interpreted as an expression of simple and pure truth. The figure of the nude truth (nuda veritas) became one of the most popular personifications in Renaissance and Baroque art. ${ }^{166}$ Numerous illustrations, such as the frontispiece of François Peyrard: De la nature et de ses lois (Paris 1793), showed "the truth unveiled by time". ${ }^{167}$

The image of the veiled goddess also became a metaphor, an allegorical motif for nature and its secrets. This goes back to the Italian philosopher Marsilio Ficino (1433-99) who, in his own commentary on the Timaeus dialogue, used the Latin velum for the Greek chiton: velum meum revelavit nemo. This not only changed the meaning of the veil into a means of concealment, it also combined it with the act of revelation. But the revelation of divine wisdom was an act done by the goddess herself. She could not be arbitrarily "unveiled". ${ }^{168}$

By way of this metaphor, both the inaccessibility of these secrets and their uncovering by science were symbolised, respectively. Especially from the late 17th to the early 19th century, such allegorical representations were very popular. A second source for these

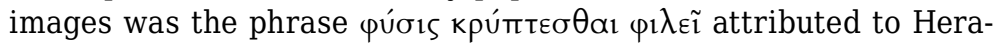
clitus (Fragmentum B 123), which was commonly translated as "Nature loves to conceal herself." Edmund Spenser popularised this image in his epic poem The Faerie Queene, published 1590-96, where nature is described as a woman with a veil. ${ }^{169}$ The motive of the unveiling of Isis appeared in many illustrations to scientific works during the 18th century.

The metaphor was then inherited by the Enlightenment movement and subsequently assigned new meanings. When the philosophers searched for alternatives to Christianity, they found them in the mysteries of Isis that were reinterpreted as a secret cult of nature and reason. ${ }^{170}$ The main representation of this theology was the legendary veiled image in the temple of Sais.

Assmann 1999b, 13; 2006.

Hornung 1999, 71-9; Burkert 2004, 79-106; Assmann 2006, 75-107.

Panofsky 1972, 156-9.

Assmann 1999b, 15.

Harrauer 1994-95, 341-2; Assmann 2006, 138.

Hadot 2006, 237.

See Hadot 2006 and compare Assmann 1999b, 20-36; 2006, 100-2. 
An early example for this concept can be found in the novel Das Heimweh by the German economist, novelist and Freemason Johann Heinrich Jung-Stilling (1740-1817). There he describes the travels and adventures of Christian von Ostenheim during several years in the Middle East. He becomes a member of a secret society in Egypt and has to undergo a rite of initiation within a pyramid. During this rite he encounters the veiled statue of Isis. He lifts the veil, sees the four heads of the statue - a woman, an eagle, a lion, and a bull - and finds the key to yet another door in the pyramid.

Numerous publications on the veiling and unveiling of nature appeared during the late 18th century in Germany and Austria. ${ }^{171}$ One centre of this discourse was the lodge "Zur Wahren Eintracht" in Vienna. ${ }^{172}$ Ignaz von Born, mineralogist and master of this lodge, compared the unveiling of Isis to modern science in a letter sent to Friedrich Nicolai, an Enlightenment philosopher in Berlin on 23 March 1787. In this letter he named the knowledge of nature as the ultimate purpose of science. For him, the image of Isis represented nature and only he who knows all her powers and strengths could unveil her and remain unpunished. ${ }^{173}$

Several other philosophers of the Enlightenment also regarded the knowledge of the truth as a dangerous gift that had to be guarded. Since the truth was part of the sublime, nobody should picture it, name it or unveil it. Immanuel Kant in his Critique of the Power of Judgment (1790) explicitly connected the concept of the sublime with the veiled image of Isis:

Perhaps nothing more sublime has ever been said, or any thought more sublimely expressed, than in the inscription over the temple of Isis (Mother Nature): "I am all that is, that was, and that will be, and my veil no mortal has removed". ${ }^{174}$

It was this unavailability of Isis that Kant admired. The goddess was sublime because she was universal, she was past, present, and future. And she was inapprehensible, no one could lift her veil. This veil was a perfect symbol for Kant's conviction that the sublime evokes wonder and terror at the same time and that man will never be able to know its true nature. ${ }^{175}$

But Kant used the image of the veiled goddess for various concepts. In the quoted note from the Critique of the Power of Judgment 
it stood for the ultimate truth, but in his paper "On a Newly Arisen Superior Tone in Philosophy", published in May 1796, in the Berlinische Monatsschrift, it symbolised the moral law:

The veiled goddess before which we on both sides bend our knees is the moral law in us in its invulnerable majesty. ${ }^{176}$

Kant obviously wanted to bridge the gap between cognitive and moral domains. Isis itself was just an image. The important thing was the veil. This was also acknowledged by Jacques Derrida in his parodistic response to Kant's essay, in which he dealt with "the intrigue of a certain veil of Isis". He, too, understood Isis exclusively as a "matter of the veil". ${ }^{177}$

The veiled goddess remained an awe-inspiring mystery and an enigma that haunted further generations. By putting the emphasis on the veil and stressing the fact that the veiled image was not identifiable, the question arose: What is behind the veil? ${ }^{178}$

The philosopher and Freemason Carl Leonhard Reinhold (17571823), who wrote an essay on the mystery of the Hebrews (1787) and interpreted the statement on the statue at Sais ("I am all that has been and is and shall be") as proof for the identity of divinity and nature, became professor for philosophy in Jena in 1788. There he introduced Kant's concept of the sublime to Friedrich Schiller (1759-1805).

In 1790 - the same year in which Kant published his Critique of the Power of Judgment - Schiller pondered on the revelation on Mount Sinai in his essay "The Mission of Moses". He picked up ideas of the Carl Leonhard Reinhold and added secular connotations to the concept of "revelation". In his eyes, the task of Moses was to reveal the secret knowledge of the ancient Egyptian priests to all the people and he combined this idea with the metaphor of the unveiling of Isis: "Beneath an old statue of Isis one could read the words: am all that is, that was, and that shall be; no mortal man has raised my veil". ${ }^{179}$ Ludwig van Beethoven kept this quote in handwriting and framed under glass on his desk. ${ }^{180}$

Three years later, in 1793, Friedrich Schiller wrote his own essay "Of the Sublime" and published it in the journal Neue Thalia:

Everything, that is veiled, everything mysterious, contributes to the terrible, and is therefore capable of sublimity. Of this variety 


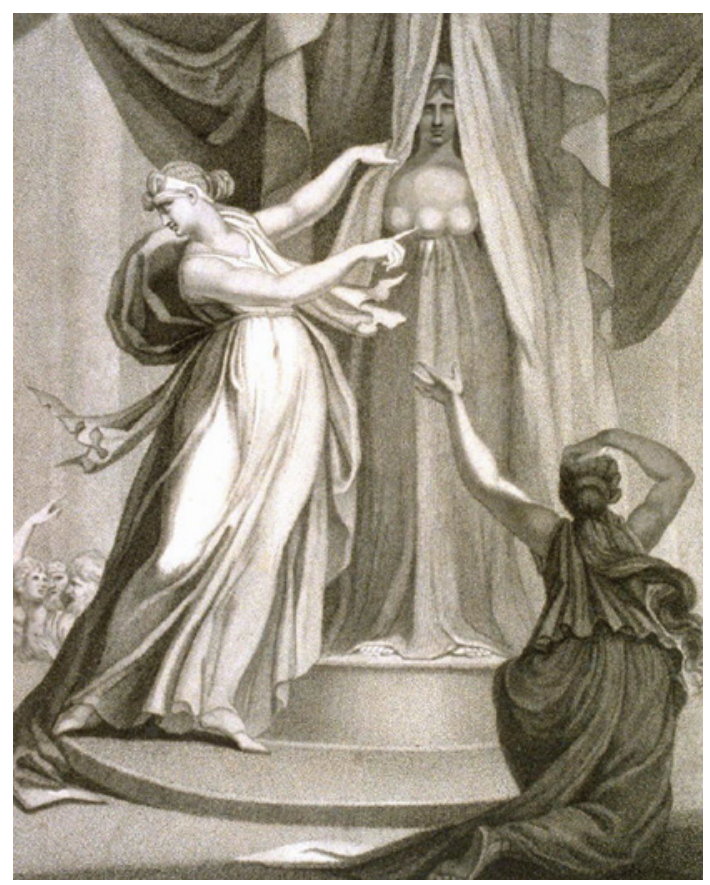

Figure 14

Henry Fuseli: Frontispiece to The Temple of Nature. Edinburgh 1803. https:// commons.wikimedia.org/ wiki/File:Frontispiece_to_ The_Temple_of_Nature. jpg? uselang=de

is the legend, that one read at Sais in Egypt above the temple of Isis. "I am everything, that is, that has been, and that will be. No mortal man has lifted my veil". ${ }^{181}$

Finally, in 1795 Schiller published the ballad "The Veiled Image at Sais", in which he set up an eternal memorial for the veiled Isis: ${ }^{182}$ a young man, driven by the thirst for knowledge, travels to Sais and demands from the priest to acquire universal wisdom. As they are standing in front of the veiled statue of Isis, he asks what is hidden behind the veil. The priest answers that it is the truth. No mortal should lift the veil until the goddess herself does. No one had ever tried, not even him. At night, the young man enters the temple without permission and, after some hesitation, lifts the veil. He collapses unconscious at the feet of the statue. No one knows what he saw. But his joy of life is gone forever.

181 "Of the Sublime. Toward the Further Elaboration of Some Kantian Ideas" by Friedrich Schiller translated by Daniel Platt. https://archive.schillerinstitute.com/ transl/trans_of_sublime.html, not to be confused with "On the Sublime" (1801). See Assmann 2006, 140.

182 Assmann 1999a; 1999b. 
For Schiller, the unveiling was equal to a revelation (apocalypse) or initiation. He does not reveal what the young man saw, but the unauthorised uncovering of the awe-inspiring truth led to grief and disaster. ${ }^{183}$ This awe-inspiring moment is perfectly illustrated by Henry Fuseli's frontispiece to the philosophical poem "The Temple of Nature; or, the Origin of Society" by Erasmus Darwin [fig. 14]..$^{184}$ where the unveiling of the statue of Isis is shown as the climactic moment of an in an initiation-like scene.

This idea was sharply criticised by the poets of Romanticism who did want to read in the Book of Nature and to discover the truth contained therein. They regarded the unveiling of the statue of Isis as a perfect metaphor for the human pursuit of knowledge. Johann Gottfried Herder wrote in a letter to Schiller dated 22 August 1795 that the thirst for truth can never cause guilt. Regardless of possible consequences - Herder names madness, blindness, and being crushed - the priestly ban and the resulting feelings of guilt were unacceptable for him. ${ }^{185}$

In his parable "The Novices at Sais", written in 1798, Novalis provides us once again with the picture of a person in pursuit of the ultimate truth. He lifts the veil of Isis in the Sais temple and looks at the divine face, just to recognise himself:

Someone arrived there - who lifted the veil of the goddess, at Sais. - But what did he see? He saw - wonder of wonders - himself. ${ }^{186}$

In the same year, 1798, Napoleon led his campaign to Egypt, heralding the era of colonialism. The Middle East experienced a period of economic and cultural decline. It became part of the "uncivilised world" and vanished behind a veil of prejudice and ignorance. ${ }^{187}$

During the following century, the search for truth, the recognition of reality, and the unveiling of secrets would have been seen as an imperative that encompassed all areas of knowledge: medicine, science, geography, humanities, and art. The veil itself became a symbol for secrets of our world and for the hidden truth that had to be uncovered, as can be seen in the 1899 sculpture La Nature se dévoilant à la Science by Louis-Ernest Barrias (1841-1909) in the Musée d'Orsay in Paris [fig. 15]. Unlike earlier representations the Isis fig-

Assmann 2006, 133-7.

184 Assmann 1997, 126-34 and 2006, 142-3; Kessler 2013.

185 See Harrauer 1994-95, 352 fn. 40.

186 Novalis 1997, 76. Compare Mahoney 1992, 112-16; Stone 2008; Ziolkowski 2008, 72-3.

187 See Galter 2008. 
Hannes D. Galter

Veil and Headscarf: Five Aspects of a Cultural Phenomenon

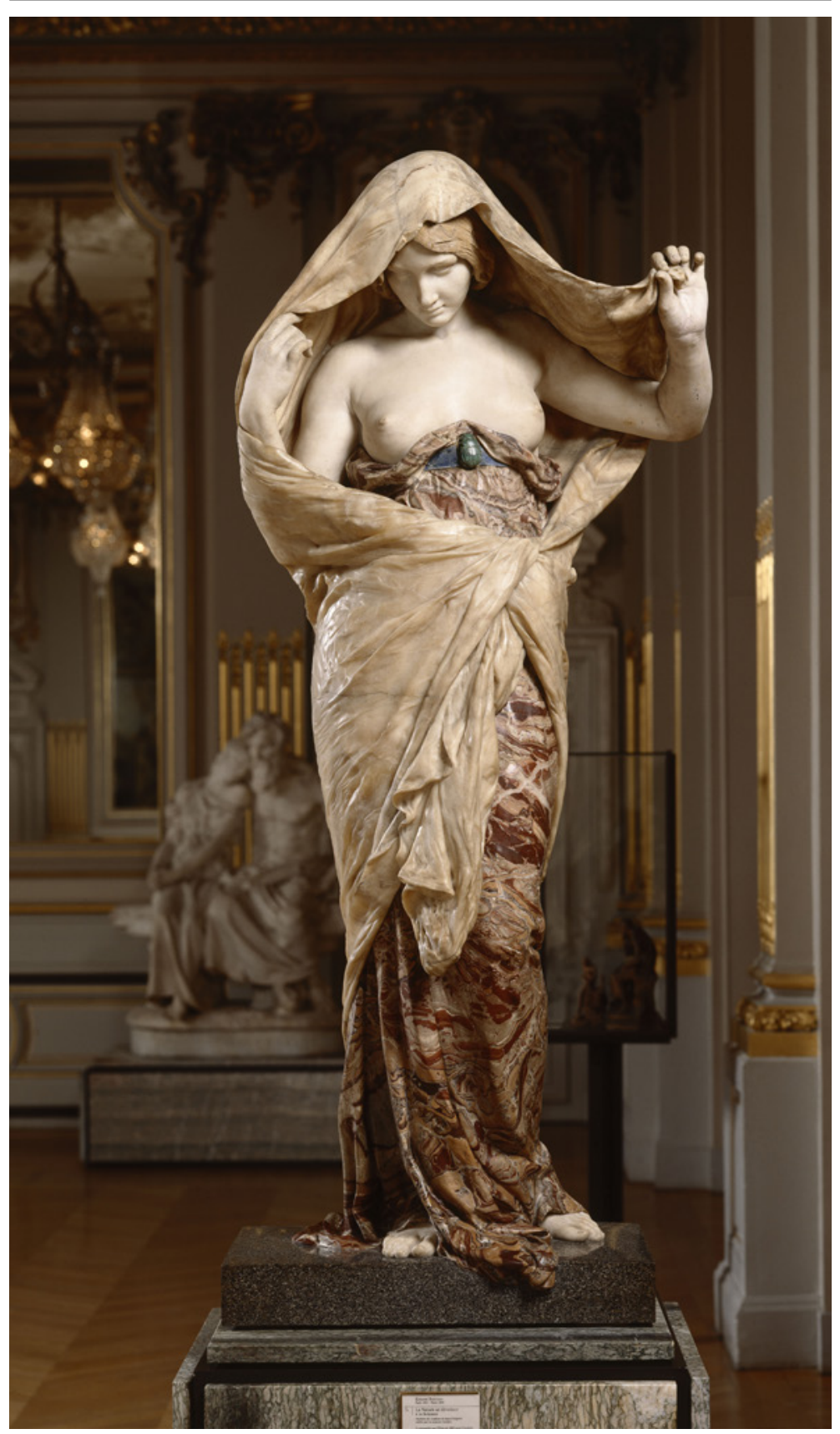

Figure 15 Louis-Ernest Barrias, La Nature se dévoilant à la Science (photo @ RMN-Grand Palais. Musée d'Orsay / René-Gabriel Ojéda) 
ure, clearly identifiable by the scarab on her garment, unveils herself before science.

The Isis metaphor also entered esoteric lore. The book Isis Unveiled. A Master-Key to the Mysteries of Ancient and Modern Science and Religion published in 1877 by Helena Blavatsky (1831-91), in which she used the metaphor of the unveiling of the goddess for the truth behind her theosophical belief, laid the theoretical basis of all esotericisms until today. ${ }^{188}$

For the poets of Romanticism, writing and discovering were one and the same thing. Therefore, the unveiling of the truth was a poetic act. But over time, the contrast between the scientific and the artistic worldview became clear. Oscar Wilde wrote in the preface to The Picture of Dorian Gray: "All art is at once surface and symbol. Those who go beneath the surface do so at their peril. Those who read the symbol do so at their peril" ${ }^{189}$ And Friedrich Nietzsche remarked 1882 in The Gay Science:

To the realists. - You sober people who feel armed against passion and phantastical conceptions and would like to make your emptiness a matter of pride and an ornament - you call yourself realists and insinuate that the world really is the way it appears to you: before you alone reality stands unveiled, and you yourselves are perhaps the best part of it - oh, you beloved images of Sais! But aren't you too in your unveiled condition still most passionate and dark creatures, compared to fish, and still all too similar to an artist in love? And what is "reality" to an artist in love! You still carry around the valuations of things that originate in the passions and loves of former centuries! Your sobriety still contains a secret and inextirpable drunkenness! Your love of "reality", for example - oh, that is an old, ancient "love"! ${ }^{190}$

And five years later he wrote in the preface to the second edition (1887):

There are some things we now know too well, we knowing ones: oh, how we nowadays learn as artists to forget well, to be good at not knowing! And as for our future, one will hardly find us again on the paths of those Egyptian youths who make temples unsafe at night, embrace statues, and want by all means to unveil, un-

189 Wilde 1891, vii. In the German translations the metaphor of the veil is again used: "Alle Kunst ist zugleich Schleier und Tiefe. Wer den Schleier aufhebt, wer die Tiefe erforscht, tut es auf eigene Gefahr".

190 Nietzsche 2001, 69. 
cover, and put into a bright light whatever is kept concealed for good reasons. No, we have grown sick of this bad taste, this will to truth, to "truth at any price", this youthful madness in the love of truth: we are too experienced, too serious, too jovial, too burned, too deep for that... We no longer believe that truth remains truth when one pulls off the veil; we have lived too much to believe this. Today we consider it a matter of decency not to wish to see everything naked, to be present everywhere, to understand and 'know' everything. ${ }^{191}$

With his negation of a reality that is not influenced by man and with his plea for an aesthetic of the hidden and veiled, ${ }^{192}$ Nietzsche strongly opposed the spirit of his time. He challenged the common belief in exploring everything and the view that reality is the last resort for finding the truth.

But this common belief prevailed. It has not only boosted the scientific development in the 20th century, it also shaped our entire worldview. According to Wolf Lotter, we have so far only tried to reduce the complexity of our world in order to break through to the single, universal truth behind it, instead of recognising the variety of possible connections within this complexity. ${ }^{193}$

The concept of the veil as a fabric that covers the truth or the reality is still in our heads. ${ }^{194}$ In the German language as well as in English the word "to veil" has strong connotations of "hiding" and "concealing".

verschleiern $=$ vertuschen $=$ verheimlichen

to veil $=$ to cover up $=$ to conceal

These connotations have been reinforced by the fact that over centuries persons who did not wish to be identified and tried to stay incognito, covered their heads or veiled their faces. The members of the Catholic fraternities performing the processions during the "Holy week" (semana santa) in Spain wear distinctive cloaks and hoods (capirotes) to keep the penance anonymous. Only their eyes are visible under the black, purple, or white hoods. Executioners and robbers covered their faces and members of the Ku Klux Klan, the American white supremacist hate group founded in 1865 in Tennessee, created fanciful robes, masks, and hats in order to terrify people and to hide their identities. Even in the fairy tale of Little Red Riding Hood,

191 Nietzsche 2001, 8 .

192 Compare Harries 2003.

193 Lotter 2020.

194 Ziolkowski 2008, 63-6. 
the wolf uses a headscarf to disguise his true identity and by doing so conceals the danger for the girl.

Against this intellectual background, it is perfectly understandable that headscarves are associated with mysteries and fears. Many people regard them as symbols of a remote and archaic part of European culture that has been overcome. During the various emancipation movements of women in the 20th century, headscarves were interpreted as signs of backwardness and a traditional, premodern and, rural lifestyle. This is still happening today and contributes to the consolidating view that an uncovered head demonstrates openness, honesty, and progress. On the other hand, we have seen the return of headscarves as fashionable accessories in recent years.

Nevertheless, the headscarf issue is increasingly becoming a touchstone for the European societies in their dealings with Muslim minorities. ${ }^{195}$ The frontline between the supporters and opponents of the headscarf no longer runs along the border between locals and immigrants, but across both camps. Many immigrant families see the increased popularity of the headscarf as a dangerous return to the traditional constraints they had escaped through their migration. On the other hand, there was a growing number of voices in the European public that considered the headscarf to be at least permissible as a sign of the acceptance of the host society. All that changed with the atrocities of the "Islamic state" and the waves of refugees caused by the civil wars in the Middle East.

Although many people dislike the public debates for and against the Muslim headscarf here in Europe, such a free, open, and straight exchange of views represents a major step forward compared to the situation in many states of the Middle East, where a similar debate is simply not possible. However, the debate should not be confined to something as superficial as the headscarf. It should also address other issues that are important for living together in a multicultural and multireligious environment. The aim of such debates must be to identify similarities in diversity, ${ }^{196}$ but also to rethink ways of maintaining differences and characteristics in order to enable a unified and harmonic social life.

195 See the papers of Carla Amina Baghajati and Gabriel Malli in the present volume.

196 See Umberto Eco, Furio Colombo, Jacques Le Goff: Accepting diversity. An interactive Handbook in Progress. http://www.tolerance.kataweb.it/eng/index.html. 


\section{Abbreviations}

$\mathrm{CAD}=$ The Assyrian Dictionary of the University of Chicago. Chicago 1956-.

$\mathrm{ETCSL}=$ Electronic Text Corpus of Sumerian Literature. http://etcsl.orinst.ox.ac.uk.

$\mathrm{NASB}=$ New American Standard Bible.

$\mathrm{PSD}=$ The Pennsylvania Sumerian Dictionary. http://psd.museum.upenn. edu.

$\mathrm{RIA}=$ Reallexikon der Assyriologie und Vorderasiatischen Archäologie. Leipzig; Berlin; New York 1928-2018.

\section{Bibliography}

Asher-Greve, J.M. (2006). "'Golden Age' of Women? Status and Gender in Third Millennium Sumerian and Akkadian Art”. Schroer, S. (ed.), Images and Gender. Contributions to the Hermeneutics of Reading Ancient Art. Freiburg; Göttingen, 41-81.

Assmann, J. (1998). "Immanuel Kant und Friedrich Schiller über Isis und das Erhabene”. Anselm, S.; Neubaur, C. (Hrsgg), Talismane. Klaus Heinrich zum 70. Geburtstag. Basel; Frankfurt am Mein, 102-13.

Assmann, J. (1999a). "Das verschleierte Bild zu Sais. Griechische Neugier und ägyptische Andacht". Assmann, A.; Assmann, J. (Hrsgg), Schleier und Schwelle. Geheimnis und Neugier. München, 45-66.

Assmann, J. (1999b). Das verschleierte Bild zu Sais. Schillers Ballade und ihre griechischen und ägyptischen Hintergründe. Stuttgart; Leipzig.

Assmann, J. (2000). Weisheit und Mysterium. Das Bild der Griechen von Ägypten. München, 35-42.

Assmann, J. (2006). Erinnertes Ägypten. Berlin.

Attinger, P.; Krebernik, M. (2005). "L'hymne à Hendursaĝa (Hendursaĝa A)". Rollinger, R. (Hrsg.), Von Sumer bis Homer. Festschrift für Manfred Schretter zum 60. Geburtstag am 25. Februar 2004. Münster, 21-104.

Avioz, M. (2009). "The Motif of Beautyin the Books of Samuel and Kings". Vetus Testamentum, 59, 341-59. https://doi.org/10.1163/156853309x445025.

Banks, I. (2000). Hair Matters. Beauty, Power, and Black Women's Consciousness. New York.

BeDuhn, J.D. (1999). “'Because of the Angels'. Unveiling Paul's Anthropology in 1 Corinthians 11". Journal of Biblical Literature, 118, 295-320. https:// doi.org/10.2307/3268008.

Benesch, C. (2013). Studien zur sozialgeschichtlichen Entwicklung der Siebenbürger Sachsen [MA thesis]. Wien: Universität Wien.

Bentley, T. (2002). Sisters of Salome. New Haven; London.

Bergler, R. (2003). "Haare und Psyche". Trüeb, R.M. (Hrsg.), Haare. Praxis der Trichologie. Darmstadt, 11-26.

Bezner, F. (2005). Vela Veritatis. Hermeneutik, Wissen und Sprache in der Intellectual History des 12. Jahrhunderts. Leiden; Boston.

Bielz, J. (1965). Die Volkstracht der Siebenbürger Sachsen. Bucharest.

Black, F.C. (2000). "Beauty or the Beast? The Grotesque Body in the Song of Songs". Biblical Interpretation, 8(3), 302-23. https://doi. org/10.1163/156851500750096363.

Boehmer, R. (1983). “Kopfbedeckung B. In der Bildkunst”. RIA, 6, 203-10. 
Boehmer, R. (1989). "Review of Furlong, Iris, Divine Headdresses of Mesopotamia in the Early Dynastic Period". Zeitschrift für Assyriologie und Vorderasiatische Archäologie, 79, 278-83.

Börker-Klähn, J. (1972). “Haartracht. A. Archäologisch”. RIA, 4(1), 1-12.

Bonatz, D. (2000). Das syro-hethitische Grabdenkmal. Untersuchungen zur Entstehung einer neuen Bildgattung in der Eisenzeit im nordsyrisch-südostanatolischen Raum. Mainz.

Brenner, A. (1997). The Intercourse of Knowledge. On Gendering Desire and 'Sexuality' in the Hebrew Bible. Leiden; New York; Köln, 45-50.

Burkert, W. (2004). Die Griechen und der Orient. Von Homer bis zu den Magiern. 2nd ed. München.

Caddy, D. (2005). "Variations on the Dance of the Seven Veils". Cambridge Opera Journal, 17(1), 37-58. https://doi.org/10.1017/s095458670500193x.

Chehade, J. (1987). "Zu Schmuckdarstellungen auf palmyrenischen Grabreliefs". Ruprechtsberger, E.M. (Hrsg.), Palmyra. Geschichte, Kunst und Kultur der syrischen Oasenstadt. Exhibition catalogue. Linz, 193-9.

Cosgrove, C.H. (2005). "A Woman's Unbound Hair in the Greco-Roman World, with Special Reference to the Story of the 'Sinful Woman' in Luke 7:36-50". Journal of Biblical Literature, 124(4), 675-92. https://doi. org/10.2307/30041064.

Damerji, M.S.B.; Kamil, A. (1999). “Gräber assyrischer Königinnen in Nimrud”. Jahrbuch des Römisch-Germanischen Zentralmuseums Mainz, 45, 1-84.

Davis, S. (2010). "'Our Faithfully Kept, Age-old Inheritance'. Transylvanian Saxon Folk Customs, Particularism and German Nationalism between the Wars". Smith, E. (ed.), Europe's Expansions and Contractions. Adelaide, 199-220.

Dellemann, E. von (2013). Der Schleier in der frühchristlichen Kunst [MA thesis]. Wien: Universität Wien.

Derrett, D.M. (1973). “Religious Hair”. Man, n.s., 8, 100-3.

Derrida, J. (1984). "Of an Apocalyptic Tone Recently Adopted in Philosophy". Oxford Literary Review, 6(2), 3-37. https://doi.org/10.3366/ olr.1984.001.

De Vaux, R. (1935). "Sur le voile des femmes dans l'Orient ancien". Revue Biblique, 44, 397-412.

Dobranski, S.B. (2010). "Clustering and Curling Locks. The Matter of Hair in Paradise Lost". PMLA, 125, 337-353, 512.

Dunn, G.D. (2005). "Rhetoric and Tertullian's De virginibus velandis". Vigiliae Christianae, 59(1), 1-30. https://doi.org/10.1163/1570072053623414.

Du Toit, D.S. (2015). "Status und Anstand als Schlüssel zum Verständnis von 1 Kor 11, 2-16. Argumentationslogische und sozialgeschichtliche Überlegungen". Jantsch, T. (Hrsg.), Frauen, Männer, Engel. Perspektiven zu 1Kor 11, 2-16. Neukirchen-Vluyn, 61-96.

Elssner, T.R. (2004). "Tertullian und der gegenwärtige Kopftuchstreit. Eine Relektüre”. Zeitschrift für Religions- und Geistesgeschichte, 56(4), 317-31. https://doi.org/10.1163/1570073042316768.

Esposito, J.L. (2002). What Everyone Needs to Know about Islam. Oxford.

Falkenstein, A. (1942). "Zu 'Inanas Gang zur Unterwelt'”. Archiv für Orientforschung, 14, 113-38.

Falkenstein, A. (1959). "Zwei Ritruale aus seleukidischer Zeit”. Lenzen, H. (Hrsg.), XV. Vorläufiger Bericht über die von dem Deutschen Archäologischen Institut und der Deutschen Orient-Gesellschaft aus Mitteln der deutschen for- 
schungsgemeinschaft unternommenen Ausgrabungen in Uruk-Warka. Winter 1956/57. Berlin, 36-44.

Fellman, M. (2009). The Social Context of Tertullian's On the Veiling of Virgins [MA thesis]. Ithaca, NY: Cornell University.

Finlayson, C. (1998). Veil, Turban and Headpiece. Funerary Portraits and Female Status at Palmyra [PhD dissertation]. Iowa City: University of lowa.

Finney, M. (2010). "Honour, Head-Coverings and Headship. 1 Corinthians 11.216 in its Social Context". Journal for the Study of the New Testament, 33(1), 31-58. https://doi.org/10.1177/0142064×10376002.

Fischer, S. (2014). "Rhetorical Figures of the Garden Motif in Song of Songs 4: 12-5:1". Journal for Semitics, 23, 810-22.

Foster, B. (1996). Before the Muses. An Anthology of Akkadian Literature. 2nd ed. Bethesda.

Frayne, D.R. (1997). Ur III Period (2112-2004 BC). Toronto; Buffalo; London.

Freemann, B.C. (1995). The Feminine Sublime. Gender and Excess in Women's Fiction. Berkeley; Los Angeles; London.

Galter, H.D. (2001). Kopftuch und Schleier. Kulturgeschichte eines orientalischen Phänomens. Graz.

Galter, H.D. (2008). “1798 - Als der Orient zum Orient wurde”. Galter, H.D.; Haas, $\mathrm{S}$. (Hrsgg), Joseph von Hammer-Purgstall. Grenzgänger zwischen Orient und Okzident. Graz, 13-28.

Garland, L. (1988). "The Life and Ideology of Byzantine Women. A Further Note on Conventions of Behaviour and Social Reality as Reflected in Eleventh and Twelfth Century Historical Sources". Byzantion, 58, 361-93.

George, A. (1992). Babylonian Topographical Texts. Leuven.

George, A. (2003). The Babylonian Gilgamesh-Epic. Introduction, Critical Edition and Cuneiform Texts. 2 vols. Oxford.

Gonzáles, J.L. (2010). The Early Church to the Dawn of the Reformation. New York.

Grayson, A.K.; Novotny J. (2014). The Royal Inscriptions of Sennacherib, King of Assyria (704-681 BC), Part 2. Winona Lake.

Griffiths, J.G. (1970). Plutarch's de Iside et Osiride Edited with an Introduction, Translation and Commentary. Cardiff.

Groneberg, B. (2000). "Haus und Schleier in Mesopotamien”. Späth, T.; Wagner-Hasel, B. (Hrsgg), Frauenwelten in der Antike. Geschlechterordnung und weibliche Lebenspraxis. Stuttgart; Weimar, 1-16.

Gruber, C. (2004). Möbeldekor aus Elfenbein. Zur Rekonstruktion von Schnitzverzierungen an altorientalischen Möbeln [PhD dissertation]. München: Ludwig-Maximilians-Universität.

Hadot, P. (2006). The Veil of Isis. An Essay on the History of the Idea of Nature. Transl. by M. Chase. Cambridge (MA).

Hallpike, C.R. (1969). "Social Hair". Man, n.s., 4, 254-64.

Hani, J. (1976). La religion égyptienne dans la pensée de Plutarque. Paris.

Harrauer, C. (1994-95). "'Ich bin, was da ist...'. Die Göttin von Sais und ihre Deutung von Plutarch bis in die Goethezeit". Wiener Studien. Zeitschrift für Klassische Philologie und Patristik, 107-108, 337-55.

Harries, K. (2003). "Mask and Veil. Why Beauty Matters". Design Philosophy Papers, 1(2), 59-72. https://doi.org/10.2752/14487130 $3 \times 13965299301632$. 
Hawkins, J.D. (1980). “Late Hittite Funerary Monuments”. Alster, B. (ed.), Death in Mesopotamia. XXVe Rencontre assyriologique internationale. Copenhagen, 213-25.

Hawkins, J.D. (2000). Inscriptions of the Iron Age. Berlin; New York.

Hemingway, P.D. (1979). The Well-Dressed Woman. New York.

Hershman, P. (1974). "Hair, Sex and Dirt”. Man, n.s., 9, 274-98.

Heyn, M.K. (2010). "Gesture and Identity in the Funerary Art of Palmyra". American Journal of Archaeology, 114, 631-61. https://doi.org/10.3764/ aja.114.4.631.

Hirschman, E.C. (2002). "Hair as Attribute, Hair as Symbol, Hair as Self". Maclaran, P. (ed.), GCB. Gender and Consumer Behavior, vol. 6. Paris, 355-66.

Hornung, E. (1999). Das esoterische Ägypten. Das geheime Wissen der Ägypter und sein Einfluss auf das Abendland. München.

Houlbert, M.H. (1979). "Social Hair. Tradition and Change in Yoruba Hairstyles in Southwestern Nigeria". Cordwell, J.M.; Schwarz, R.A. (eds), The Fabrics of Culture. The Hague, 349-98.

Jacobsen, T. (1973). "The Sister's Message". Journal of the Ancient Near Eastern Society, 5, 199-212.

Jacobsen, T. (1987). "Pictures and Pictorial Language (The Burney Relief)". Mindlin, M.; Geller, M.J.; Wansbrough, J.E. (eds), Figurative Language in the Ancient Near East. London, 1-11.

Jantsch, T. (2015a). "Einführung in die Probleme von 1Kor 11,2-16 und die Geschichte seiner Auslegung". Jantsch, T. (Hrsg.), Frauen, Männer, Engel. Perspektiven zu 1Kor 11, 2-16. Neukirchen-Vluyn, 1-60.

Jantsch, T. (2015b). "Die Frau soll Kontrolle über ihrem Kopf ausüben. 1 Kor 11, 10". Jantsch, T. (Hrsg.), Frauen, Männer, Engel. Perspektiven zu 1Kor 11, 2-16. Neukirchen-Vluyn, 97-144.

Jeremias, A. (1931). Der Schleier von Sumer bis heute. Leipzig.

Kant, I. (1993). "On a Newly Arisen Superior Tone in Philosophy". Fenves, P. (ed.), Raising the Tone of Philosophy. Late Essays by Immanuel Kant, Transformative ritique by Jacques Derrida. Baltimore, 51-82.

Kant, I. (2000). Critique of the Power of Judgment. Transl. by Paul Guyer and Eric Matthews. Cambridge.

Kanz, E.; Rothbächer, O. (2008). Kirchen- und Festtracht von Stolzenburg/Siebenbürgen. 2. Aufl. Heubach.

Kenaan-Kedar, N. (2012). "Sculpted Palmyrian Funerary Female Portraits with Extensive Jewellery Sets. A Revisionist Reading of Their Meanings and Impact". Capetić, M. et al. (eds), Art History. The Future Is Now. Studies in Honor of Vladimir P. Goss Celebrating his 70th Birthday. Rijeka, 108-20.

Kessler, S.J. (2013). Erasmus Darwin, Henry Fuseli and The Temple of Nature. Religion, Poetry and Art in Enlightment Natural History [MA thesis]. Chapel Hill: University of North Carolina.

Klatt, N. (1985). "Kants Kniefall vor der verschleierten Isis". Zeitschrift für Religions- und Geistesgeschichte, 37, 97-117.

Klaver, S.F. (2019). Women in Roman Syria. The Cases of Dura-Europos, Palmyra, and Seleucia on the Euphrates [PhD dissertation]. Amsterdam: University of Amsterdam.

Kobler, F. (1970). "Eva - Maria”. Reallexikon zur Deutschen Kunstgeschichte, 6, 417-38. http://www.rdklabor.de/w/?oldid=88833.

Kohlmeyer, K.; Strommenger, E. (Hrsgg) (1982). Land des Baal: Syrien, Forum der Völker und Kulturen. Ausstellungskatalog. Mainz: Zabern. 
Koslin, D.G. (2008). “'He Hath Couerd my Soule Inwarde'. Veiling in Medieval Europe and the Early Church". Heath, J. (ed.), The Veil. Women Writers on Its History, Lore, and Politics. Berkeley, 160-70.

Krag, S.; Raja, R. (2018). "Unveiling Female Hairstyles. Markers of Age, Social Roles, and Status in the Funerary Sculpture from Palmyra". Zeitschrift für Orient-Archäologie, 11, 242-77.

Kramer, S.N. (1951). "'Inana's Descent to the Netherworld' Continued and Revised". Journal of Cuneiform Studies, 5, 1-17. https://doi. org/10.2307/1359570.

Kraus, H, (1982). "Eve and Mary. Conflicting Images of Medieval Woman". Broude, N.; Garrard, M.D. (eds), Feminism And Art History. Questioning The Litany. Boulder, CO, 79-99.

Krieger, V. (2012). "Adam als Liebespartner. Zur Konstruktion eines neuen Männlichkeitsideals in Sündenfalldarstellungen des frühen 16. Jahrhunderts". Guth, D.; Priedl, E. (Hrsgg), Bilder der Liebe. Liebe, Begehren und Geschlechterverhältnisse in der Kunst der frühen Neuzeit. Bielefeld, 29-66.

Kultermann, U. (2006). "The 'Dance of the Seven Veils'. Salome and Erotic Culture around 1900". Artibus et Historiae, 27(53), 187-215. https://doi. org/10.2307/20067116.

Lambert, W.G. (1987). "Devotion. The Languages of Religion and Love". Mindlin, M.; Geller, M.J.; Wansbrough, J.E. (eds), Figurative Language in the Ancient Near East. London, 25-39.

Lambin, R. (1995). "Paul et le voile des femmes". Clio. Histoire, femmes et sociétés, 2. http://journals.openedition.org/clio/488.

Lampe, P. (2012). "Paulus und die erotischen Reize der Korintherinnen (1 Kor 11, 2-16)”. Knieling, R.; Ruffing, A. (Hrsgg), Männerspezifische Bibelauslegung. Göttingen, 196-207.

Leach, E.R. (1958). "Magical Hair". The Journal of the Royal Anthropological Institute of Great Britain and Ireland, 88, 147-64. https://doi. org/10.2307/2844249.

Leick, G. (1994). Sex and Eroticism in Mesopotamia. London; New York.

Lobsien, V. (2010). Transparency and Dissimulation. Configurations of Neoplatonism in Early Modern English Literature. Berlin, 185-236.

Lotter, W. (2020). Zusammenhänge. Wie wir lernen, die Welt wieder zu verstehen. Hamburg.

Mageo, J.M. (1996). "Hairdos and Don'ts. Hair Symbolism and Sexual History in Samoa”. Frontiers. A Journal of Women Studies, 17(2), 138-67. https:// doi.org/10.2307/3346607.

Mahoney, D.F. (1992). "Human History as Natural History in 'The Novices of Sais' and 'Heinrich von Ofterdingen'”. Historical Reflections. Réflexions Historiques, 18, 111-24.

Malik, S. (2008). "'She Freed and Floated on the Air'. Salome and her Dance of the Seven Veils". Heath, J. (ed.), The Veil. Women Writers on Its History, Lore, and Politics. Berkeley, 139-59.

Marshall, J.E. (2017). Women Praying and Prophesying in Corinth. Gender and Inspired Speech in First Corinthians. Tübingen.

Marshall, J.P. (2010). "Hair and Chaos". Boccalatte, S.; Jones, M. (eds), Trunk. Vol. 1, Hair. Sydney, 147-51.

Milton, J. (2001). Complete Poems, vol. IV. The Harvard Classics. New York 190914. Bartleby.com. https://www. bartleby.com/4. 
Moorey, P.R.S. (1996). "A Stone Replica of an Early Dynastic III Royal Hairstyle?". Gasche, H.; Hrouda, B. (eds), Collectanea Orientalia. Histoire, arts de l'espace et industrie de la terre. Etudes offertes en hommage à Agnès Spycket. Paris, 227-38.

Nietzsche, F. (2001). The Gay Science. With a Prelude in German Rhymes and an Appendix of Songs. Cambridge.

Nissinen, M. (2016). "Akkadian Love Poetry and the Song of Songs. A Case of Cultural Interaction". Hiepel, L.; Wacker, M.-T. (eds), Zwischen Zion und Zaphon. Studien im Gedenken an den Theologen Oswald Loretz (14.01.192812.04.2014). Münster, 145-70.

Novalis (1997). Philosophical Writings. Transl. by M.M. Stoljar. Albany.

Orend, M. (1958). "Die mittelalterliche Herkunft der siebenbürgisch-sächsischen Frauentracht". Forschungen und Fortschritte, 32, 59-62.

Orthmann, W. (1971). Untersuchungen zur späthethitischen Kunst. Bonn.

Otto, A. (2016). "Professional Women and Women at Work in Mesopotamia and Syria (3rd and early 2nd millennia BC): The (Rare) Information from Visual Images". Lion, B.; Michel, C. (eds), The Role of Women in Work and Society in the Ancient Near East. Berlin; Boston, 112-48.

Panofsky, E. (1972). Studies in Iconology. Humanistic Themes in the Art of the Renaissance. London.

Parlasca, K. (1987). "Ein antoninischer Frauenkopf aus Palmyra in Malibu". Frel, J.; Houghton, A.A.; True, M. (eds), Ancient Portraits in the J. Paul Getty Museum 1. Malibu, 107-14. Occasional Papers on Antiquities 4.

Penchansky, D. (2013). "Beauty, Power, and Attraction. Aesthetics and the Hebrew Bible". Bautch, R.J.; Racine, J.-F. (eds), Beauty and the Bible. Toward a Hermeneutics of Biblical Aesthetics. Atlanta, 47-66.

Pergament, D. (1999). "It's Not Just Hair. Historical and Cultural Considerations for an Emerging Technology". Chicago-Kent Law Review, 75, 41-59.

Raja, R. (2017). "Powerful Images of the Deceased. Palmyrene Funerary Portrait Culture between Local, Greek and Roman Representations". Boschung, D.; Queyrel, F. (eds), Bilder der Macht. Das griechische Porträt und seine Verwendung in der antiken Welt. München, 319-48.

Riemschneider, M. (1985). Die Welt der Hethiter. Essen.

Römer, C. (1922). "Sächsische Volkstracht”. Siegmund, H. (Hrsg.), Sächsisches Wehr- und Mehrbuch: ein Volksbuch. Mediasch, 308-11.

Römer, W.H.P. (1993). "Mythen und Epen in sumerischer Sprache. A. Mythen". Kaiser, O. et al. (Hrsgg), Texte aus der Umwelt des Alten Testaments III/3. Gütersloh, 351-506.

Ruprechtsberger, E.M. (1987). Palmyra. Geschichte, Kunst und Kultur der syrischen Oasenstadt. Exhibition catalogue. Linz.

Salzberg, A. (s.d.). "Hair Coverings for Married Women. Why most Orthodox Women Cover Their Hair, whether with Wigs, Hats or Scarves". My Jewish Learning. https://www.myjewishlearning.com/article/hair-coverings-for-married-women.

Schachner, Ş.; Schachner, A. (1996). "Eine späthethitische Grabstele aus Maraş im Museum von Antakya". Anatolica, 22, 203-26.

Schenk, A. (1992). Deutsche in Siebenbürgen. Ihre Geschichte und Kultur. München.

Schiller, F. (1970). "Die Sendung Moses”. Hahn, K.-H. (ed.), Historische Schriften. Erster Teil. Weimar, 377-97. 
Schirrmacher, T. (2007). Paul in Conflict with the Veil. An Alternative Interpretation of 1Corinthians 11:2-16. 2nd ed. Nürnberg.

Schmidt, R.; Förderreuther, M. (2011). Kirchen- und Festtagskleidung der Siebenbürger Sachsen: Lebendiger Brauch und gelebte Tradition im ländlichen Bereich. München.

Schubert, H.-A. (1980). Nachbarschaft und Modernisierung - Eine historische Soziologie traditioneller Lokalgruppen am Beispiel Siebenbürgens. Köln; Wien.

Scola, O.; Bretz-Schwarzenbacher, G.; Schiel, A. (1987). Die Festtracht der Siebenbürger Sachsen. München.

Sefati, Y. (1998). Love Songs in Sumerian Literature. Critical Edition of the Dumuzi-Inana Songs. Bar Ilan.

Selz, G.J. (2004). "Early Dynastic Vessels in 'Ritual' Contexts”. Wiener Zeitschrift für die Kunde des Morgenlandes, 94, 185-223.

Sleeman, M. (1981). "Medieval Hair Tokens". Forum for Modern Language Studies, $17,322-36$.

Sokołowski, Ł. (2017). "Portrait as a Medium? Interpreting Funerary Portrait Reliefs from Palmyra as a Means of Communication”. Cascino, R. et al. (eds), TRAC 2016 Proceedings of the Twenty-Sixth Theoretical Roman Archaeology Conference. Rome, 17-35.

Steinmann, A. (ed.) (2018). Verhüllt, enthüllt! Das Kopftuch. Ausstellungskata$\log$. Wien.

Stol, M. (2004). "Perücke”. RIA, 10(5-6), 435.

Stol, M. (2016). Women in the Ancient Near East. Boston; Berlin.

Stone, A. (2008). "Being, Knowledge, and Nature in Novalis". Journal of the History of Philosophy, 46(1), 141-64. https://doi.org/10.1353/ hph.2008.1839.

Struble, E.; Rimmer, J.; Herrmann, V. (2009). "An Eternal Feast at Samal. The New Iron Age Mortuary Stele from Zincirli in Context". Bulletin of the American Schools of Oriental Research, 356, 15-49.

Synnott, A. (1987). "Shame and Glory. A Sociology of Hair". The British Journal of Sociology, 38, 381-413. https://doi.org/10.2307/590695.

Synnott, A. (2016). The Body Social. Symbolism, Self and Society. London; New York.

Takács, I.-C. (2017). "Multicultural and Intercultural Common Heritage in Transylvania". International Journal of Education, Culture and Society, 2(5), 14757. https://doi.org/10.11648/j.ijecs.20170205.12.

Thompson, C.L. (1988). "Hairstyles, Head-Coverings, and St. Paul. Portraits from Roman Corinth". The Biblical Archaeologist, 51(2), 99-115. https:// doi.org/10.2307/3210030.

Treiber-Netoliczka, L. (1968). Die Trachtenlandschaften der Siebenbürger Sachsen. Marburg/L.

Tsevat, M. (1975). "The Husband Veils his Wife (Hittite Laws, §§ 197-98)". Journal of Cuneiform Studies, 27, 235-40. https://doi.org/10.2307/1359326.

Tsukimoto, A. (1987). Untersuchungen zur Totenpflege (kispum) im alten Mesopotamien. Kevelaer; Neukirchen-Vluyn.

Tumanov, V. (2011). "Mary Versus Eve. Paternal Uncertainty and the Christian View of Women". Neophilologus, 95, 507-21. https://doi.org/10.1007/ s11061-011-9253-5.

Van der Toorn, K. (1995). "The Significans of the Veil in the Ancient Near East”. Wright, D.P.; Freedman, D.N.; Hurvitz, A. (eds), Pomegranates and Golden 
Bells. Studies in Biblical, Jewish, and Near Eastern Ritual, Law, and Literature in Honor of Jacob Milgrom. Winona Lake, 327-39.

Vogelsang-Eastwood, G.; Vogelsang, W. (2008). Covering the Moon. An Introduction to Middle Eastern Face Veils. Leuven; Paris; Dudley (MA).

Waetzoldt, H. (1985). "Kopfbedeckung A. Philologisch". RIA, 6, 197-203.

Wilcke, C. (1975). "Formale Gesichtspunkte in der sumerischen Literatur". Lieberman, S.J. et al. (eds), Sumerological Studies in Honor of Thorkild Jacobsen on his Seventieth Birthday, June 7, 1974. Chicago, 205-316.

Wilde, O. (1891). The Picture of Dorian Gray. London; New York.

Wolin, E. (2014). "Mary of Chartres. Images of Women in the Middle Ages". Anemoi. New College of Florida Journal of Pre-Modern Studies, 2, 13-22.

Zettler, R.L. (1998). “The Burial of a King and a Queen”. Zettler, R.L.; Horne, L. (eds), Treasures from the Royal Tombs of Ur. Philadelphia, 33-8.

Ziolkowski, T. (2008). "The Veil as Metaphor and as Myth". Religion \& Literature, $40,61-81$. 


\title{
The Veil in Ancient Near Eastern Religions and Cultures Some Remarks
}

Maria Giovanna Biga

Sapienza Università di Roma, Italia

\begin{abstract}
In the texts from Syrian cities like Ebla, Mari, Emar and Ugarit there are several words indicating textiles destined to cover the head and sometimes also the shoulders of women. In the Ebla texts PAD (-TÚG2) (Sumerian), gú-du-mu/ma-ga-da-ma-tum/ ma-da-ma-tum (Semitic) is a textile, often of linen, used to cover the body, the shoulders and the head. During the great ritual of royalty at Ebla the queen received the veil only after several days of trip. The veil at Ebla is destined mostly, but not only, for brides. Married women in Syria did not always wear the veil.
\end{abstract}

Keywords Veil. Linen textile. Ebla texts. Married women. Eblaite ritual of royalty.

Summary 1 Introduction. - 2 Covering the Head in Mesopotamia and Syria. 3 Covering the Head in the Texts from Syria. The Ebla Texts (III Millennium BC). - 3.1 The Veil, a Textile to Cover. - 3.2 The Veil, PAD(-TÚG), Given to Girls as Dowry on Their Marriage. - 3.3 The Veil for the Queen in the Great Ritual. - 3.4 The Veil among the Textiles Given to Women to Bring into the Tomb. - 4 Iconographic Evidence. -5 The Veil in the Texts from Syria of the Second Millennium BC. -6 Conclusions.

\section{Introduction}

In modern European languages, the word 'veil' (voile, Schleier, velo, etc.) can mean a simple object, one of the temporary forms of body covering, a piece of textile, a headdress, a robe, an accessory, an object of protection, a type of fab-

I would like to thank Hannes Galter and the organisers of this conference very much for their kind invitation and wonderful hospitality in Graz. Some years ago, H. Galter wrote a book on the veil (Galter 2001) and he is a great expert on this topic. 
ric or a garment connected with female social and religious life (for example the veil of the bride, or of nuns or that used during mourning).

The veil covers, hides, obscures and reveals, or distinguishes. Sometimes it is gender-oriented, has a religious value, a normative function, or signifies identity. The veil is a symbol of oriental exoticism and, of course, also of the Islamic world and is considered an emblem of (real or supposed) oppression of Muslim women.

The veil has been studied by semiologists, historians of religion, historians of art and anthropologists. In the field of historical sciences and historical-religious studies, reflection on the veil and the veiled body starts from the assumption that there is no veil used to cover the body or a part thereof in an innocuous way, nor is there an act of revealing that it is completely innocent. The intentions and implications of veiling and unveiling are part of the codes established in cultural and social contexts. The possibility, and sometimes the obligation, to show the body and/or face, freeing oneself of the covering or covering veil, as well as the need to escape the gaze of others, may depend on normative factors and take on ideological meanings.

The meanings and values are essentially determined by the triple function connecting the visual, spatial and ethical dimensions that condition the use of the veil as a "garment" on the one hand and the product of an ideology on the other. The dynamics of visibility and invisibility of the body (or of some of its parts) regulate the public and private spheres of social life not only with words and the force of law, but also with images.

We use the word 'veil' to indicate something light and often transparent usually to put on the head. However, in the Greek world and also in the ancient Near Eastern pre-classical world, different types of textiles have been used to cover the head and 'veil' is represented by different realities.

Sometimes, it is a true veil in our acceptation of the word, although it seems to cover only the head and not the whole face. Various cases of veils are known in the classical world, which instead cover the whole face and not just the head. The girls, especially when they marry, go to meet the groom with their face covered and the groom will uncover their face by lifting the veil. This act seems to allude to the fact that only the husband will then be able to have a sexual relationship with the married girl. The veil would then be a metaphor for defloration, represented by the veil being raised. ${ }^{1}$

In the classical world the veil is a garment used in case of mourning (Penelope), for a bride (Andromache) or a symbol of virginity and purity (Nausicaa). ${ }^{2}$ 


\section{Covering the Head in Mesopotamia and Syria}

Even if there are many texts from the Near East regarding textiles, and textiles destined for women, veils are not often mentioned, and there is no data to understand whether they are a complete garment or simply a veil on the head. The matter of the veil is probably one of the most complex to analyse.

Around 2000, the Centre for Textile Research (CTR) in Copenhagen launched its research programme to investigate textile production from the Bronze Age to the Iron Age from the archaeological, experimental and linguistic points of view. The CTR together with the textile research programme launched in Paris-Nanterre by $\mathrm{CN}$ RS organised several conferences on different topics regarding textiles, which produced several volumes. ${ }^{3}$

Despite many books that have studied garments for women, the veil appears in only a few cases. Furthermore it is difficult to integrate or to support our written evidence with the little iconographic evidence. ${ }^{4}$

Studying the terminology of textiles, it is evident that in all the cultures of the ancient Near East a woman could cover her head with different types of fabrics. In Sumerian, the term 'gada', which indicates linen, is also used to indicate veil, or a linen textile used to cover. It is sometimes translated as 'veil'.

From the texts, especially those from the Syrian region and from centres like Ebla, Mari, Emar and Ugarit, it is possible to conclude that women covered their heads on some occasions but not regularly even if they were married. However, it is not possible to infer that the veil was the typical garment given to women for their marriage; in many cases of weddings there is no mention of the veil.

The Mesopotamian goddesses do not have a veil. Either they have the distinctive horned cap, as a mark of their divinity or, as in the case of the goddess Gula, they have a high headdress or elaborate headdresses.

The statue of the goddess Nanaya and statues of other female deities $^{5}$ were covered by kusitu-garment, a ceremonial garment used in religious ceremonies with particularly rich and brilliant decoration, but it is impossible to know if it covered also the heads of other statues.

Few statues of goddesses have survived but the other iconographic evidence documents the presence of different headdresses.

3 For example Michel, Nosch 2010; Breniquet, Michel 2014; Lion, Michel 2016; Harlow, Michel, Quillien 2020.

4 See Nadali in this volume; Otto 2016 with previous bibliography; Couturaud 2020

5 Joannès 2020, 31-41. 
In the first tablet of the Maqlu exorcism for the gods of the night ${ }^{6}$ there are spells used in the magic rite to dissolve witchcraft. It is said:

Spell. I call upon you, gods of the night,

with you I invoke the night, veiled bride,...

kal-la-tum kut-tùm-tum is normally translated 'veiled bride'; kuttumtum from the Semitic verb *ktm, Akk. katāmu 'to cover' (with a veil). From this text it appears that the bride could be veiled.

The goddess Inanna does not wear a veil. When she descends into the underworld, the doorman opens the first door for her and strips her of the large crown on her head. Then, eventually, life is returned to Inanna. He lets her out from the seventh door and returns the large crown to her head. Inanna, and also Ishtar, never have a veil. In some cases, the goddess has a crown.

In texts with myths regarding marriages of deities such as the marriage of Martu, there is no mention of the veil. The princess who is ready to marry the young Martu prepares her dowry but the veil is not mentioned.

In two myths with the marriages of deities, the marriage of the god Enlil with the goddess Sud and that of the god Enlil with the goddess Ninlil there is no mention of a veil on the heads of the goddesses, also because we do not have a description of the marriage itself.

\section{Covering the Head in the Texts from Syria. The Ebla Texts (III Millennium BC)}

The Ebla archives of third millennium BC Syria are very rich written sources on textiles. The texts found in 1975 in the large archive L. 2769 and its vestibule L. 2875 include more than 14,000 tablets and fragments, and their largest corpus is that of the monthly accounts of textile deliveries. These are more than 600 large tablets on which the Eblaite scribes registered the deliveries of textiles on different occasions, starting from the period of the penultimate king of Ebla, Irkab-damu.

Despite the presence of so many texts related to textiles, it is difficult to know the wardrobe of ancient Eblaites for several reasons. First of all, the texts mention mainly fabrics and not garments. It is hard to identify the types of textiles, also because we do not have examples of them from the archaeological finds of the time; the iconography does not help very much either. ${ }^{7}$

6 For a similar ritual at Ebla see infra.

7 For the iconography on textiles and veil see the article of Nadali in this volume, with previous bibliography. 
However, even Egyptologists, who have so many textiles preserved in the tombs, have some difficulty attributing their name despite several very precise texts with lists of many different types of textiles. ${ }^{8}$

The most common textiles quoted in the Ebla texts have already been studied. ${ }^{9}$

\subsection{The Veil, a Textile to Cover}

Considering the data from all the Ebla texts, it is evident that some textiles are given mostly to men, while others such as the zara ${ }_{6}$-TÚG are given mostly to women, and especially to the important ladies of the court. When we have a number of zara-textiles, it is almost certain that it is followed by a list of the most important ladies of the court. Other less important female courtiers are quoted in hierarchical order after the most important, and normally receive textiles-NI. $\mathrm{NI}^{10}$ that are sometimes also given to men.

Zara-textiles are attributed to men, although rarely, but it is not possible to say whether they were given to them on some particularly important occasions or if they were for their wives. Therefore, even if it is probable that they were particularly precious because they are attributed to the important women on some special occasions such as marriages, rituals etc., we cannot be sure which type of textile we are dealing with.

In the Ebla texts, several words are used to indicate something to protect the head:

- níg-lá-sag: a textile to tie around the head, given to men on different occasions, to messengers who must travel on long trips.

- aktum-TÚG ti-TÚG sag en: a textile destined for the head of the king; turban.

- $\mathrm{PAD}(-\mathrm{TÚG})($ Sumerian$)=g u ́-d u-m u / m a-g a-d a-m a-t u m / m a-d a-m a-$ tum translated as 'veil', but in fact a textile, often of linen, of different colours (white, black, yellow-green, embroidered), used to cover (the body, the shoulders and eventually also the head). ${ }^{11}$

- J. Pasquali, in a first paper (1997), studied the Semitic word maga-da-ma-tum and its variants, ${ }^{12}$ without a possible translation of the word. Several years later, thanks to the use of both the

8 See Roccati 1970, 1-10; Herslund 2010, 68-80; Jones 2010, 81-109.

9 See Pasquali 1997, 2010 with previous bibliography; Biga 2010.

10 For a long list of zara-textiles given to important ladies of the court on occasion of the ritual of royalty, see the text TM.75.G.2417 quoted in Biga, Capomacchia 2012, 27-30.

11 Pasquali 2010, 175-9.

12 Pasquali 1997, 246-8. 
words gú-du-mu and ma-ga-da-ma-tum and of their Sumerian translation (PAD(-TÚG)) in the texts of the great ritual of royalty, he was able to conclude that these words indicate the veil. ${ }^{13}$

- gú-du-mu, Semitic reading of the Sumerian PAD(-TÚG), is a noun from Semitic *ktm, Akkadian katāmu and can be compared with Akkadian kutummu used in Syrian Mari texts to indicate the veil.

- ma-ga-da-ma-tum with the graphic variant ma-da-ma-tum is a noun (scheme ma12a-3) of the Semitic *ktm; probably is the Eblaite writing of the word PAD(-TÚG).

- PAD(-TÚG) in the Ebla texts often has the meaning 'something used to cover', 'to cover' and it is translated also as 'to cover with a veil', 'to veil'. This textile is mostly of linen.

To quote some examples:

TM.75.G.1794+ARET III 469 (TM.75.G.3534) obv. III 18-23: 12 aktum-TÚG ti-TÚG 1 gada-TÚG šu-DAG 1 gada-TÚG PAD-sù en siin 'A $-z a-a n^{k i}$. To the king the aktum-ti-textiles are given, as usual, in large number and 1 linen textile is destined for cover of the textiles during the trip to the palace of the king of Ebla in 'Azan.

TM.75.G.2625 (king Ishar-damu, vizier Ibbi-zikir, month i-rí-sa) rev. I 11-14: 1 gada-TÚG/PAD/ 1 giš-gigir-II/ I-bi-zi-kir/; 1 linen textile to cover a chariot with two wheels of Ibbi-zikir.

TM.75.G.10152 (king Ishar-damu, vizier Ibrium, month i-ba-sa) rev. II 4'-6': 1 gada-TÚG PAD/giš-alam/d Ba-ra-ma/; 1 linen textile to cover a statue of the goddess Barama.

TM.75.G.10165 (king Ishar-damu, vizier Ibbi-zikir, monh lost) obv IV 2'-4': 1 gada-TÚG PAD/1 a-gi-šum/en; 1 linen textile to cover 1 agishum? of the king.

TM.75.G.10187 (king Ishar-damu, vizier Ibbi-zikir, month ig-za) rev. III 9-15: 20 aktum-TÚG ti-TÚG 1 dùl-TÚG Ma-ri 1 gada-TÚG mu (TÚG)-mu en 1 gada-TÚG/ PAD/ ti-TÚG/en; again 1 linen textile is used to cover/to protect the ti-textiles of the king.

In TM.75.G.10196 (king Ishar-damu, vizier Ibbi-zikir, month lost) rev. IV 2-15: 2 textiles and some objects of gold and 1 gada-TÚG PAD-sù níg-ba en 'À-du ${ }^{\mathrm{ki}} E n$-h̆ar-Ar-miki šu-mu-tak ${ }_{4} ; 2$ textiles and some objects of gold and 1 linen textile to cover them, gifts destined for the king of the city of Adu, Enar-Armi delivered. 
It must be noted that according to Archi 2002, 182 and fn. 27:

the main garment for a woman was the zara-textile, a cloak reaching to the ground [...]. The head was covered by a long shawl, gudùl textile. A statuette from Ebla and some from Mari show women in their ceremonial clothes with the cloak and shawl.

In fact, in a ritual for the gods of the night from archive L 2712 of Ebla, ${ }^{14}$ seven black-cloaked women take part. In the text (rev I 1-5) is written: 7 dam ga-du-ma-tum gu-dùl-TÚG gi ${ }_{6}$ gaba ${ }^{\mathrm{d}} \mathrm{Gi}_{6}$-an: 'seven women covered in a black cloak stand in front of the gods of the night'. ga-du-ma-tum can be interpreted as /kattum-ä t-um/, verbal adjective of *ktm (to cover). Here the women are covered with a black textile-gu-dùl, which covers the body and possibly also the head. I prefer to translate 'covered' and not 'veiled'. The women are covered with gu-dùl textiles.

The gods mentioned in this Eblaite rite recall the gods of the first tablet of the Maqlû ritual in a surprising way: the bride of the god of the night is indicated by the same term, kallatum.

\subsection{The Veil, PAD(-TÚG), Given to Girls as Dowry on Their Marriage}

The veil PAD(-TÚG), gú-du-mu / ma-ga-da-ma-tum / ma-da-ma-tum in Semitic, ${ }^{15}$ is destined mostly, but not only, for brides.

It is mentioned in the dowry of princesses of the Eblaite court or of other girls of important Eblaite families on their marriage; in the texts there are lists of textiles given with jewels ${ }^{16}$ as part of the dowry. ${ }^{17}$ I would like to quote some examples.

In the text with deliveries of textiles of the principal archive L.2769, TM.75.G.2329, the dowry that Damurdashein received on her marriage to the son of the king or the king of DUlu (Byblos) himself is listed $:^{18}$ dozens of colored and white textiles, of wool and of linen. Among them there is 1 linen textile..., 1 linen textile for a veil? (1 gada-TÚG mu ${ }_{4}$ PAD ti-TÚG), 1 linen textile. The veil is made of linen. ${ }^{19}$

14 For this ritual see Biga 2003; Fronzaroli 2012.

15 Pasquali 2009.

16 For the jewels see Archi 2002

17 For examples of dowries see Biga 1996, 63-72; 2014, 77-8; 2018; Archi 2002.

18 For this marriage see Biga 2014. For the identification of DUlu with Byblos see recently Biga 2012; 2016; 2017 with previous bibliography. For a different opinion, see Archi 2016. See now Biga, Steinkeller 2021.

19 gada-TÚG PAD ti-TÚG, translated as 'veil', still needs to be studied in more detail. 
The text TM.75.G.1679 ${ }^{20}$ with the dowry for Tiabarzu, a girl of the family of the vizier Ibrium, registers a long list of precious gold objects and several textiles destined for this girl and some textiles destined for male and female personages who participated in the ceremony.

It should be noted that the veil, which is normally given to the bride, is not mentioned here. It is difficult to suppose that the complete dowry for the girl was written on another tablet. We can conclude that the veil was not always given among the textiles of the dowries.

Another example of a dowry (and of textiles distributed to people involved in the marriage ceremony) is in the text TM.75.G.1776 (king Ishar-damu, vizier Ibrium, month lost), obv. I 1-III $11 .{ }^{21}$ Among the textiles given to the princess Zanehi-Mari, who married the son of Ibara of the city of Ashu, one gada-textile is quoted. In this text, there is no veil (PAD-TÚG); probably the textile gada here indicates the veil.

The deliveries of textiles on the marriage of princess Tagrish-da$\mathrm{mu}$, daughter of the last king of Ebla Ishar-damu, to the king of Nagar are registered in two monthly accounts of textiles TM.75.G.1249+ and TM.75.G.1250+. In the second text TM.75.G.1250+, there is a long list of many precious objects and different types of textiles destined for the princess as dowry to bring to her new house. Among these textiles, there is no veil. ${ }^{22}$ The beginning of the text TM.75.G.1250+ quotes the textiles given to Ultum-HU.HU, the son of the king of Nagar, who poured oil on the head of the Eblaite princess.

In conclusion, the veil is sometimes given to brides but not always, and it is not the most important ritual act during the Eblaite marriage ritual which is pouring oil on the head of the bride.

20 For the edition of the text see Biga 2018.

21 For the complete transcription of the dowry see Biga 2020.

22 For these texts see also Archi 2002, 172-3 with different translations of names of textiles. 


\subsection{The Veil for the Queen in the Great Ritual}

A great ritual for the Ebla royalty performed by the royal couple, ${ }^{23}$ refers, at the beginning, to the marriage of the queen with the king of Ebla which took place possibly some time before. It was necessary to have a royal couple to perform this ritual. Because of the presence of the veil given to the queen during ceremonies in honour of some royal ancestors in the city of Binash, some scholars consider this to be a marriage ritual.

In my opinion, and also in the opinion of A.M.G. Capomacchia, historian of religions, who studied the texts with me, too many funerary elements are present in these rituals to be able to propose that we are dealing with a marriage ritual. Marriage and funerary rituals are both rites of passage but one is festive, while the other is sombre. The fact that the same objects and textiles are given to girls on their marriage and for funerary ceremonies is not proof that the two occasions are similar. In fact, it is obvious that the same objects are given to the girls in both cases not because they are similar but because the objects necessary for girls on both occasions are, of course, the same.

In both texts, the marriage of the king and queen is quoted at the very beginning of the texts. Then, after many ceremonies, and when they are already in the Mausoleum of Binash, a veil is placed on the face and hands of the queen seven times.

ARET XI 1 (78-80): wa-a/ti-ig-da-ra-ab/dam/mu-a-bí-iš-tum/wa-a/ $\mathrm{PAD} / m a-l i k-t u m / b a-n a-s a /\langle s ̌ u>-s a / w a-a / d u-a-b a-$ áš/gú-du-mu/ma-liktum/7/dam/Bí-na-áśki $/$ en/ù/ma-lik-tum/tuš; and the woman who provides the clothes recites the blessing. And she covers the queen with a veil, her face and her hands. And she covers (with the veil) the queen seven times, the woman of Binash, (when) the king and the queen sit.

The word for veil is PAD; in rev. IX 15 is written gú-du-mu. gú-du$m u$ is interpreted as a noun from Sem *ktm, "cover (with a veil)". This word is the Semitic writing of PAD(-TÚG) and corresponds to Akkadian kutummu, which was also used in Mari to indicate the veil of the bride.

The text ARET XI 1 is the oldest and contains more phonetic writings like all the oldest texts of Ebla.

23 For the last edition of the ritual, see ARET XI. For different opinions on the interpretation of the ritual, see Biga, Capomacchia 2012; Bonechi 2016 with previous bibliography. The ritual is not for a marriage; marriages were celebrated with music and a banquet that could continue for several days. Afterwards, there was no honeymoon trip! We normally think of the voyage de noces but this is a practice born in the Belle Epoque period. After the wedding a royal couple such as that of Ebla had to perform a ritual to take on their royal role and they were protected by the divine couple KUra and Barama. Of course, during the ritual they also performed some acts for the fertility of the queen. 
In ARET XI 2 (82-84) the same ritual action is described, but the veil is quoted as PAD(-TÚG), with the use of the logogram. ${ }^{24}$

Apparently the queen is veiled only at this point, after a trip of several days with the king and not when she left her father's house.

The significance of the veil here is probably not that of a veil for a bride. We are dealing with another ritual connected with the cult of ancestors, purification etc.

Some scholars have used the quotation of veil in this ritual as proof that we are dealing with a marriage ritual. ${ }^{25}$ However, from all the texts quoting marriages it is evident that in the marriage at Ebla, the defining act was the pouring of oil on the head of the bride.

It should be noted that the two administrative texts related to the ritual from the monthly accounts of textile deliveries also describe the textiles received by the king and the queen but no veil given to the queen is mentioned. ${ }^{26}$

The veil has been interpreted ${ }^{27}$ as having great symbolic value during Eblaite marriage, but, in my opinion, this is not very evident from the texts.

\subsection{The Veil among the Textiles Given to Women to Bring into the Tomb}

In some texts in which the funerary gifts for women are registered, the veil is quoted among the textiles but sometimes not. The veil is never given as a funerary gift to men and this is the most important difference between gifts for men and women.

In TM.75.G.2632 (king Ishar-damu, vizier Ibrium, month gi-ni) obv. IV 6-V 3:

1 zara-textile coloured red, 1 veil, 1 dururu-band... 2 brooches of silver weighing $x$ sekels of silver with head of gold, 1 and half sekels of gold for 1 object-kùsal for Dati-tu queen of the reign of Lumnan, for her funerary service [i.e. for her tomb], Ishar delivered.

In the text TM.75.G.2334, written on the death of princess Daribdamu, there is a long list of the many funerary gifts she received.

24 In the text ARET XI 2 (115) of the ritual is written that the head of the god KUra is not veiled (nu PAD); in the text ARET XI 3 (24) is written that the heads of the gods KUra and Barama are not veiled (nu PAD-TÚG) (see Fronzaroli 2020).

25 Pasquali 2010, 175-9.

26 Biga, Capomacchia 2012.

27 Pasquali 2010. 
TM.75.G.2334 obv. I 1-III 17: "15 aktum-ti-textiles, 2 zara-textiles dark red, 2 long textiles dark red, 6 zara-textiles, 6 gudul-textiles, 2 brooches..." then many jewels.

It should be noted that the textiles given as funerary gifts are the same as the ones girls are given for their dowry ${ }^{28}$ but in this case, the veil is not mentioned.

The veil is not included among the textiles given to six already dead women of the royal family (and possibly buried in the same tomb).

In the text TM.75.G.2337 + 4269, the death of a woman of the king is quoted. There is no veil among the textiles given to this woman.

TM.75.G.2337 + 4269 (king Ishar-damu, vizier Ibbi-zikir, month lost) obv. VII 16-VIII 6:

1 zara-textile to Magaradu woman of the king for her funeral ceremony, 2 textiles dul, 2 embroidered and of good quality waistbands to Irkab-damu and Igrish-Halab, 1 zara-textile for Dusigu (on the occasion of the death of) Magaradu delivered.

Women never receive a veil for a purification ceremony after a death.

\section{Iconographic Evidence}

Iconographic evidence does not help very much because very few representations of women have been found in palace $\mathrm{G}$ of Ebla. A plaque, TM.03.G.1150, shows a seated woman wearing a long cloth and a big shawl. ${ }^{29}$

Also a statuette, TM.83.G.400, shows a seated woman wearing a long cloth and a long shawl covering the head and most of the body. ${ }^{30}$

L. Colonna d'Istria compared the representations of women in Ebla and Mari in the third millennium BC, concluding that they all had a "robe-manteau" covering the head and the shoulders; ${ }^{31}$ women dressed in this way were involved in some ceremonies. He quotes the translation as the 'veil' of Pasquali. 'Robe-manteau' is the textile that Pasquali defines the "veil".

In the shell inlays of Mari of the third millennium BC, women always have their hair covered by different types of headdress, a polos crown or a turban, a piece of cloth intended to cover the hair. It is depicted as interlacing thin strips covering the entire area of the hair. ${ }^{32}$

28 See Pasquali 2005.

29 See Nadali in this volume, fig. 3.

30 Matthiae 2008, 152-3.

31 Colonna d'Istria 2019, 8

32 Couturaud 2020, 164-7. 
In the cylinder seals from Mari of the third millennium BC, women are represented with a long cloth and a shawl on their heads, also covering their shoulders. Sometimes under the shawl women have a polos crown. ${ }^{33}$

There is no possibility to prove that all the married women of the Ebla court regularly used a veil to cover their head. The two small statues possibly representing the queen-mother Dusigu and the last queen Tabur-damu, do not have a veil. ${ }^{34}$

Priestesses are not necessarily given the veil. Some lists of textiles given to daughters of kings of Ebla who went as priestesses to some sanctuaries of the kingdom of Ebla have already been published but the veil is not quoted. ${ }^{35}$

\section{The Veil in the Texts from Syria of the Second Millennium BC}

The veil was considered an important garment in the Syrian wedding ritual, especially in Mari of the second millennium BC.

In the Mari texts, the veils (plural) of the bride are quoted. The textile-mardatum was probably a veil made with an embroidered textile.

In ARM XXVI 10: 15 of the time of king Zimri-Lim: "we put the veils on the head of the young girl" in a ritual of marriage.

According to Durand, ${ }^{36}$ the textile mardatum was also used to cover the head. In fact, in a letter, ARM V 76 (=LAPO 16 10: 3'-8') of the time of king Yasmah-Addu, textiles-mardatum have been requested but (veils) kutummum have been received. ${ }^{37}$

In a list of textiles from Mari of the second millennium there is the word kutummum (veil). ${ }^{38}$

According to Durand the veil kutummum was worn on the head as is evident from the marriage ritual and is a simple veil. Mardatum was a more sophisticated textile, embroidered.

In the Mari texts, the constitutive act of the marriage was placing the veil on the head of the young woman. In the case of the marriage of Šibtu, the daughter of the king of Aleppo, the veil was put on the

33 Colonna d'Istria 2019, 6-7.

34 See Nadali in this volume, figs 5-6. For a description of these two statues, see Matthiae 2009 and 2010.

35 See for example the gifts of Tinib-dulum when she went as a priestess to Luban, Archi 2002, 170-1.

36 Durand 2009, 11, 55-6.

37 Durand 1988, 99-104.

38 Durand 2009, 55-6; Beaugeard 2010, 288. A veil was placed on the head of the bride also in the Old Assyrian period, according to the texts of Kültepe (Michel 1997). 
head of the bride by the messengers of the king of Mari because the king was not in Aleppo. Durand supposes that the veil was normally placed on the head of the bride by her husband.

Other Mari texts document that the veil was a typical garment worn by married women.

It is possible that, also in Babylon, married women were normally veiled. In the Gilgamesh epic, quoted by Durand, ${ }^{39}$ is written: "my friend covered his face as a married woman".

In Emar of the middle Babylonian period, the ritual describing the installation of a high priestess of Baal gives an indication of her apparel during the ceremony. A red paršigu-scarf is tied on the head of the high priestess on the day of her installation. On the last day of the installation rite, the seventh day, when she leaves her father's house, she wears "a multicoloured scarf (íb-lá birmi) which covers her head (ukattamu) like a bride ${ }^{40}{ }^{40}$ Abrahami and Lion, who recently studied the textiles given to the priestess, have seen an analogy with a wedding ceremony and consider that the scarf was also worn by women during the wedding ceremony. ${ }^{41}$ But the scarf is not a veil.

In the dowry lists from the Middle Babylonian period, a veil is not quoted for the bride among the textiles and gender-marked garments. ${ }^{42}$

In the texts from Ugarit, ${ }^{43}$ despite a large number of terms regarding textiles and clothing, few garments, textiles or complements can be identified with any certainty as exclusively or preferentially used by women. According to W. Watson "no differentiation is made between clothes for women or men", ${ }^{44}$ with a few possible exceptions such as psm 'veil'.

An incomplete ivory statuette (RS 9.283) from the "Résidence de la Reine-mère" shows a seated woman with a piece of fabric covering her hair. ${ }^{45}$

In the Bible too, there are very few mentions of veiled women. A veil (tsai'if) on the head or on the face is attested in only two episodes of the Bible. One is Gen 24,65, the episode of Rebecca who puts a veil on her head when her future husband Isaac is introduced to her.

The other is Gen 38,1-26: Tamar, daughter-in-law of Judas, dresses herself as a prostitute and puts a veil on her face to deceive Judas, to have sexual relations with him and bear his child.

Durand 1988, 103 fn. 47.

40 Abrahami, Lion 2020, 13-14.

41 Abrahami, Lion 2020, 14.

42 Abrahami, Lion 2020, 22.

43 See Matoian, Vita 2020, 47.

44 Watson 2018, 382.

45 Matoian, Vita 2020, 49. 
In the Hebrew ritual of marriage there is the act of covering the bride with a veil. The veil in the Bible can characterise different types of women. ${ }^{46}$

\section{Conclusions}

The veil is a textile of different types and colours destined for women, especially for brides.

From the Ebla texts, it emerges that the veil was given to women among the textiles of the dowry, but not always.

Furthermore, married women in Syria did not always wear the veil.

There are many more explicit mentions in the legal texts that have been dealt with by Mario Fales in this volume.

\section{Abbreviations}

ARET = Archivi Reali di Ebla. Testi, Roma

MEE = Materiali Epigrafici di Ebla, Napoli-Roma

ARM = Archives Royales de Mari, Paris

$\mathrm{TM}=$ Tell Mardikh

\section{Bibliography}

Abrahami, P.; Lion, B. (2020). "Textiles and Gender During the Middle Babylonian Period (c. 1500-1000 BCE). Texts from Syria and Babylonia". Harlow, M.; Michel, C.; Quillien, L. (eds), Textiles and Gender in antiquity from the Orient to the Mediterranean. London, 13-30.

Archi, A. (2002). "Jewels for the Ladies of Ebla". Zeitschrift fuer Assyriologie, 92(2), 161-99. https://doi.org/10.1515/zava.2002.92.2.161.

Archi, A. (2016). "Egypt or Iran in the Ebla Texts?". Orientalia, 85, 1-49.

Beaugeard, A.-C. (2010). "Les textiles du Moyen-Euphrate à l'époque paléo-babylonienne d'après un ouvrage récent". Michel, C.; Nosch, M.-L. (eds), Textile Terminologies in the Ancient Near East and Mediterranean from the Third to the First Millennia BC. Oxford, 282-9.

Biga, M.G. (1996). "Prosopographie et datation relative des textes d'Ebla”. Durand, J.-M. (ed.), Mari, Ebla et les Hourrites. Paris, 29-72.

Biga, M.G. (2003). "A Ritual from Archive L.2712 of Ebla". Marrassini, P. (ed.), Semitic and Assyriological Studies Presented to Pelio Fronzaroli. Wiesbaden, 54-69.

Biga, M.G. (2010). "Textiles in the Administrative Texts of the Royal Archives of Ebla (Syria, 24 Century B.C.) with Particular Emphasis on Coloured Textiles". Michel, Nosch 2010, 146-72.

46 Moro 2017, 136-9. 
Biga, M.G. (2012). "Tra Egitto e Siria nel III millennio a.C.". Atti dell'Accademia delle Scienze di Torino, 146, 17-36.

Biga, M.G. (2014). "The Marriage of an Eblaite Princess with the King of DUlu". Gaspa, S. et al. (eds), From Source to History. Studies on Ancient Near Eastern Worlds and Beyond Dedicated to Giovanni Battista Lanfranchi on the Occasion of his 65th Birthday on June 23.2014. Münster, 73-9.

Biga, M.G. (2016). "La Syrie et l'Egypte au III millénaire av. J.-C. d'après les archives d'Ebla". Comptes rendus de l'Académie des Inscriptions et Belles Lettres, 691-711.

Biga, M.G. (2017). "Voies commerciales, ports et marchands de Syrie, Anatolie et Méditerranée orientale au III millénaire av. J.-C.”. Pallas, 104, 51-9. https://doi.org/10.4000/pallas.7204.

Biga, M.G. (2018). "Gioielli per una fanciulla della corte di Ebla”. Vacca, A.; Pizzimenti, S., Micale, M.G. (a cura di), A Oriente del Delta. Scritti sull'Egitto ed il Vicino Oriente antico in onore di Gabriella Scandone Matthiae. Roma, 63-78.

Biga, M.G. (2020). "Some Remarks on Textiles and Gender in the Ebla Texts of the Third Millennium BCE". Harlow, M.; Michel, C.; Quillien, L. (eds), Textiles and Gender in Antiquity from the Orient to the Mediterranean. London, 153-62.

Biga, M.G.; Capomacchia, A.M.G. (2012). "I testi di Ebla di ARET XI. Una rilettura alla luce dei testi paralleli". Revue d'Assyriologie et d'Archeologie Orientale, 106(1), 19-32. https://doi.org/10.3917/assy.106.0019.

Biga, M.G.; Steinkeller, P. (2021). "In Search of Dugurasu”. Journal of Cuneiform Studies, 73, 9-70.

Bonechi, M. (2016). "A Passive and Therefore, Prized, Bride. New Proposals for the Queen's Wedding in the Ebla Royal Rituals". Revue d'Assyriologie et d'Archéologie Orientale, 110(1), 53-78. https://doi.org/10.3917/assy.110.0053.

Breniquet, C.; Michel, C. (eds) (2014). Wool Economy in the Ancient Near East and the Aegean. Oxford.

Colonna d'Istria, L. (2019). Remarques iconographiques et épigraphiques concernant des empreintes de sceaux-cylindres inscrits de Mari, Ville II. Abrahami, P.; Battini, L. (eds), Ina ${ }^{d}$ marri u qan tuppi. Par la bêche et le stylet! Mélanges offerts à Olivier Rouault. Oxford, 5-22.

Couturaud, B. (2020). "A Visual Investigation of Feminine Garments at Mari during the Early Bronze Age". Harlow, M.; Michel, C.; Quillien, L. (eds), Textiles and Gender in Antiquity from the Orient to the Mediterranean. London, 163-77.

Durand, J.-M. (1988). Archives épistolaires de Mari I/1 (ARM XXVI). Paris.

Durand, J.-M. (2009). La nomenclature des habits et des textiles dans les textes de Mari (ARM XXX). Paris.

Ferrara, M.; Saggioro; A., Viscardi, G.P. (a cura di) (2017). Le verità del velo. Firenze.

Ferrara, M.; Viscardi, G.P. (2017). “Introduzione”. Ferrara, Saggioro, Viscardi 2017, 11-23.

Fronzaroli, P. (1993). Testi rituali della regalità (ARET XI). Roma.

Fronzaroli, P. (2012). "The Eblaic Supplication to the Gods of the Night". Revue d'Assyriologie et d'Archéologie Orientale, 106, 165-76. https://doi. org/10.3917/assy.106.0165.

Fronzaroli, P. (2020). "Fragments et éclats pour ARET XI". Studia Eblaitica, 6, 162-6. 
Galter, H.D. (2001). Kopftuch und Schleier. Kulturgeschichte eines orientalischen Phänomens. Graz.

Giammellaro, P. (2017). "Velo si dice in molti modi. Coprirsi il capo nell'epica greca arcaica". Ferrara, Saggioro, Viscardi 2017, 49-57.

Joannès, F. (2020). "The Goddess Nanaja's New Clothes". Harlow, M.; Michel, C.; Quillien, L. (eds), Textiles and Gender in antiquity from the Orient to the Mediterranean. London, 31-41.

Jones, J. (2010). "The 'Linen List' in Early Dynastic and Old Kingdom Egypt. Text and Textile Reconciled”. Michel, Nosch 2010, 81-109.

Harlow, M.; Michel, C.; Quillien, L. (2020). Textiles and Gender in Antiquity from the Orient to the Mediterranean. London.

Herslund, O. (2010). "Cloths-Garments-and Keeping Secrets. Textile Classification and Cognitive Chaining in the Ancient Egyptian Writing System". Michel, Nosch 2010, 68-80.

Lion, B.; Michel, C. (eds) (2016). The Role of Women in Work and Society in the Ancient Near East. Boston.

Matoian, V.; Vita, J.-P. (2020). "Textiles and Gender at Ugarit". Harlow, M.; Michel, C.; Quillien, L. (eds), Textiles and Gender in Antiquity from the Orient to the Mediterranean. London, 43-58.

Matthiae, P. (2008). Gli archivi reali di Ebla. Milano.

Matthiae, P. (2009). "The Standard of the Maliktum of Ebla in the Royal Archives Period". Zeitschrift fuer Assyriologie, 99, 270-312.

Matthiae, P. (2010). Ebla. La città del trono. Torino.

Michel, C. (1997). "Un témoignage paléo-assyrien en faveur du port du voile par la femme mariée”. Nouvelles Assyriologiques Brèves et Utilitaires, 40, 38.

Michel, C.; Nosch M.-L. (eds) (2010). Textile Terminologies in the Ancient Near East and Mediterranean from the Third to the First Millennia BC. Oxford.

Moro, C. (2017). "Il velo nel mondo biblico e nel giudaismo". Ferrara, Saggioro, Viscardi 2017, 135-46.

Otto, A. (2016). "Professional Women and Women at Work in Mesopotamia and Syria (3rd and Early 2nd Millennia BC): The (Rare) Information from Visual Images". Lion, B.; Michel, C. (eds), The Role of Women in Work and Society in the Ancient Near East. Boston, 112-48.

Pasquali, J. (1996). "La 'vestizione' della statua della dea 'TU ad Ebla”. Nouvelles Assyriologiques Brèves et Utilitaires, 128, 111-13.

Pasquali, J. (1997). "La terminologia semitica dei tessili nei testi di Ebla". Miscellanea Eblaitica, 4, 217-70.

Pasquali, J. (2005). "Remarques comparatives sur la symbolique du vêtement à Ebla". Kogan, L. et al. (eds), Memoriae I.M. Diakonoff. Winona Lake, 165-84.

Pasquali, J. (2009). "Les équivalents sémitiques de PAD-túg, 'voile', dans les texte d'Ebla”. Nouvelles Assyriologiques Brèves et Utilitaires, 11, 12-15.

Pasquali, J. (2010). “Les noms sémitiques des tissus dans les textes d'Ebla”. Michel, Nosch 2010, 173-85.

Roccati, A. (1970). "Una tabella lignea inscritta da Gebelein". Research in the Sociology of Organizations, 45, 1-10.

Viscardi, G.P. (2017). "Verità e rappresentazione. Logiche discorsive e pratiche performative del dis/velamento nell'antica Grecia”. Ferrara, Saggioro, Viscardi 2017, 59-87.

Watson, W.G.E. (2018). "Terms for Textiles, Clothing, Hides, Wool, and Accessories in Ugaritic. An Etymological Study". Aula Orientalis, 36, 353-90. 


\title{
Veiling in Ancient Near Eastern Legal Contexts
}

\section{Frederick Mario Fales}

Università degli Studi di Udine, Italia

\begin{abstract}
Particularly interesting textual evidence on the use of the veil in ancient Mesopotamia comes from 15th-14th century BC Assyria. No comprehensive code of laws has reached us from this age, but only a collection of 14 tablets, which are named ad hoc "Middle Assyrian Laws", from the religious and political capital Aššur. Veiling was prescribed for appearances in public of married women, even if widows, but also applied to the vaster class of women who were 'Assyrian', i.e. of free status and native-born. On the other hand, prostitutes had no right to wear a veil, and severe punishments were foreseen for transgression; and the same applied to slave women. These harsh rulings on the veil and other matters in the "Middle Assyrian Laws" do not, curiously enough, find counterparts in the contemporaneous legal deeds, which show women endowed with a much more liberal status. Perhaps the "Laws" reflected normative codifications applying to the stricter moral and intellectual 'climate' of the city of Aššur, dominated by its temple and royal palace.
\end{abstract}

Keywords Veil. Ancient Mesopotamia. Middle Assyrian Period. Legal provisions. Harsh enalties. Coeval documents.

Summary 1 Introduction. - 2 The Lexicon and Semantics of 'Veiling'. - 3 The Middle Assyrian Laws. - 4 Wider Contexts. - 5 Conclusions. 
To a prestigious colleague, Prof. Muazzez İlmiye Çiğ, who in 2006 defended with spirit the origin of the headscarf in ancient Sumer, as learned from Landsberger, Güterbock and Kraus in the late 1930s, ${ }^{1}$ against the allegation of anti-Islamic slander by a Turkish tribunal in the Erdoğan climate, and was acquitted with all charges dropped.

Kudos and all best wishes to Ms. Çiğ, now past her 106th birthday!

\section{Introduction}

My experience in studies of the Ancient Near East has taught me some crucial lessons over the years - and one of them is, that it is very difficult to trace social and cultural phenomena diachronically through Syro-Mesopotamian history down to Hellenism, expecting to find single strands of evidence, of a rewarding clarity in their consistency and long-term coherence. Although the almost one million clay tablets written in cuneiform script from $3000 \mathrm{BC}$ to the beginning of the Christian era allow us to follow the history of innumerable words and their relevant concepts in detail, ${ }^{2}$ it is very rare to encounter terms which have not been subject to changes of meaning or variation in applications over the centuries, or in different local settings. Even very basic Assyro-Babylonian items, like bitu 'house' and ilu 'god', show many and quite complex semantic nuances over the millennia. ${ }^{3}$

In addition to documents of many different types - from religious, literary and historiographic works to 'everyday' texts such as letters of public and private nature and legal deeds on many business matters - the ancient Mesopotamians have also fortunately left us a vast repertoire of scholarly texts dealing with words, which we call collectively "lexical texts": word lists, dictionaries, mono/plurilingual vocabularies, etc. These texts are of concrete help to us, for example in order to establish which Assyro-Babylonian words were synonyms, or to find and explain specific meanings in different dialects. ${ }^{4}$ On the negative side, however, Mesopotamia has unfortunately left us only very few treatises or 'handbooks' in which these words are

1 See, e.g., Çı̆̆ 1988 for an account of this interesting phase of Near Eastern studies in Turkey - brought about by the removal from office and forced escape of Jewish scholars from Nazi Germany and their employment as academics in Turkish universities and museums by the Atatürk government - which lasted from c. 1935 to the end of WWII; see also Schmidt 2010 (especially page 17, on Çı̆̆ and Kraus).

2 See Streck 2010, for a rough calculation of the existing cuneiform tablets, which is perhaps even somewhat conservative.

3 For bitu, see CAD B, 283b-296a. For ilu, CAD I-J, 91a-103b.

4 See Cavigneaux 1980-83 for a full survey of these textual materials. 
commented and discussed outright: for example, we completely lack a manual like Vitruvius' text on Roman architecture De architectu$r a$ from which the relevant Latin technical terminology may be fully understood and appreciated. ${ }^{5}$

Thus, despite the great abundance of written sources at his disposal, the student of ancient Mesopotamia is forced to examine one by one the individual textual occurrences (as much as they exist), and also to look through the ancient lexical attestations (if any), attempting to deduce on his own specific meaningful contexts for items of social or cultural interest. The result is that even rather conflicting interpretations on various themes may be, and are regularly, offered by scholars: and this has kept the discipline of Assyriology in a very vivacious and stimulating state, even in this day and age of totalising computer-based analyses.

\section{The Lexicon and Semantics of 'Veiling'}

On the present occasion, I will try to contribute to our common theme by devoting my attention in particular to the practice of veiling as applied to women in ancient Mesopotamian texts - a subject which has been touched upon in general social or gender studies relevant to the region, but rarely with an in-depth or detailed attention. ${ }^{6}$ Specifically, I would like to carry on the presentation and discussion of Mesopotamian material on the veil opened by M.G. Biga in this volume, concentrating in particular on the Middle- and Neo-Assyrian textual corpus, in its legal contents.

But, to start out, let us take a step backward, toward the already quoted lexical texts. Going through the Assyro-Babylonian dictionaries, it is clear that the action of 'veiling' belongs to the vaster semantic sphere of 'covering', for which the most important verb is katāmu, referring to a number of practices with garments, not necessarily (or not only) involving the head, but also with reference to the body in general. ${ }^{7}$ However, we may risk misunderstanding matters here: in a few figurative depictions of women in ceremonial garb,

5 In point of fact, however, an ancient Mesopotamian agronomic manual, of course not as detailed as Lucius Columella's De re rustica, but able to withstand some comparison with Cato's De Agri Cultura, known as the "Farmer's Instructions", has survived from the 18th century BC in the traditional language of Sumerian: see the latest, and fully updated, edition by Civil 1994.

6 Among the most detailed surveys touching the theme of the veil, see Van der Toorn 1995, 1996, 43-7; Stol 1995, 2016, 22-8 and passim.

7 See CAD K, 298a-303a. Perhaps the most famous quote involving katāmu is in the epic of Gilgamesh, VIII 59, where the protagonist, in mourning over Enkidu's corpse, "covered his friend's face, like a bride's". 
we may observe a full garment covering the shoulders and the entire torso, whose upper part was formed by a sort of hood (cappuccio, $\mathrm{Ka}$ puze) which covered the head. In other words, we are not - or at least are not always - dealing with a veil as a separate and detached garment, but at times with the upper edge of a light mantle in the form of a hood to cover the hair of the woman. This would explain the fact that the verb katāmu was used to describe the general covering of the body with any garment.

On the other hand, the action of specifically covering the head is sometimes explicitly described in the texts; e.g., an epistolary text from city-state of Mari on the Middle Euphrates in the 18th century $B C(A R M 2,113)$ holds the following advice by king Zimri-Lim to one of his daughters, who was in some difficulties after an unsuccessful political marriage to a foreign ruler: "Go! Take the road to your house. If this is not acceptable, veil yourself and go away (kutmi-ma atlakim)!".

A derivative noun from katāmu is kutummu, which refers to reed mats and covers of various types, but is also used to designate a veil. E.g. in another letter from Mari, on the occasion of a royal marriage (AEM 1/1 106 no. 10), emissaries from the city were sent upstream on the Euphrates to Aleppo, and charged with placing veils in a ceremonial fashion on the head of the bride, the local princess. In their report to the king, they write:

We have hastened, and the bridal gift which our master made us bring we have brought inside, and the veils [kutummū] we have laid on the daughter. ${ }^{9}$

From testimonies such as these, it appears that veiling presented specific links to the married status of a woman: as seen above, we may find its use during marriage ceremonies, as well as in more normal circumstances of life. However, whether a married woman was always required to remain veiled while outside her home or not, is unclear from these limited data. It is thus necessary to widen our gaze beyond the Mari correspondence, where we encounter other difficulties but also some rewarding information.

8 Cf. Stol, who notes that this passage could imply "that women in Mari had to be veiled outside the home" $(2016,26)$, quoting a well-known parallel from the Koran, 33:59, "O prophet, say to thy wives, and thy daughters, and the womenfolk of the believers, that they let down part of their mantles (jaläbīb) over them; that is more suitable for their being recognised and not insulted. Allah is forgiving, compassionate". This passage, together with 34:31 (where humur is used), constitutes one of the very few outright references to the veil in the Koran. See Prenner in this volume.

9 Stol 2016, 23. 
Let us start from the difficulties: for example, we have no clear-cut term for 'veil' in the texts from the earliest literary language of Mesopotamia - Sumerian, used in the third millennium BC - and even in later times, the southern part of Mesopotamia - Babylonia, from around present-day Baghdad to the Persian Gulf - has yielded little or no ancient textual proof for the veiling of women on a regular basis. On the positive side, instead, relatively significant evidence for the use of a veil as a regular fixture of feminine apparel in relation to the married condition, comes from the Middle and Upper Euphrates region (where originally nomadic Amorite tribes had settled, from 2000 BC onward) and from the northern plains of Assyria, possibly even reaching Anatolia (present-day Turkey), where the cuneiform archives in the Hittite Empire (mid-second millennium BC) have some references to veiling. ${ }^{10}$

\section{The Middle Assyrian Laws}

Let us therefore concentrate our gaze on this northern Mesopotamian horizon from 1400-1300 BC, an age which we call the 'Middle Assyrian period'. Here, we find the full-fledged territorial state of Assyria, which progressively asserted itself in a network of international relations involving all of Western Asia during the Late Bronze Age. The older citystate of Aššur on the Tigris had now become the political and religious capital, marked by its royal palace, its temple-tower or ziggurat, but especially by its vast sanctuary to the eponymous god Aššur, a numen loci like Athena for Athens in Greece. A new political-religious ideology was developed, through which the god Aššur bestowed upon the newly-enthroned king not only full divine legitimation of his rule, but also the specific command to enlarge the territory with his "just sceptre" in outlying zones, i.e. to enlarge the "land of Aššur". ${ }^{11}$ All through the remainder of Assyrian history, down to the Neo-Assyrian period, and the fall of the last capital, Nineveh, in 612 BC, this ideology of state and then imperial expansion would be followed and implemented. ${ }^{12}$

No comprehensive code of laws has come to us from the Middle Assyrian period - differently, for example, from king Hammurabi's wellknown assemblage of legal clauses from Babylonia of a few centuries earlier. We only have a collection of 14 tablets, which are named ad hoc 'Middle Assyrian Laws', with many items in a fragmentary condition. Discovered in various findspots at the Assyrian capital Ashur, this group of texts is in the main formed by 11th-century copies of originals dated some 300 years earlier, and thus might go back to

11 Postgate 1992.

12 See e.g. Fales 2001; Radner 2015. 
vaster original codifications, although even a unitary origin of theirs is uncertain. The contents ${ }^{13}$ show groupings by quite broad themes. Thus tablet A, with 59 provisions, deals in general with women, but ranges through a wide set of issues: theft, blasphemy, bodily harm and assault, sexual offenses, homicide, false accusations, inheritance, marriage and property, veiling, witchcraft, pledges and debts, and finally abortion. Tablet B, with 20 provisions, deals with inheritance, agriculture and irrigation; tablet $\mathrm{C}+\mathrm{G}$, with 11 articles, regards pledges and deposits; the remaining tablets are less complete and significant. The provisions of the Middle Assyrian Laws have a casuistic ("if...then") form, similarly to many Babylonian law codes, with each provision or paragraph marked by horizontal rulings.

Of particular interest to us is the best-preserved Tablet A, which deals with regulations on the theme of veiling in its 40 th and 41st paragraphs. It is interesting to note that the verb used here for veiling is no longer katāmu, but a different word, pasāmu (pussumu). This verb means specifically 'to veil', as we can understand from the context itself, but also from the lexical texts, which equate it on one hand with katāmu 'to cover', and on the other with pazāru (puzzu$r u$ ) 'to conceal'. In sum, the verb pasāmu had a technical meaning, which specifically referred to the concealment of the woman's head, or perhaps even part of the face, through the application of a veil. ${ }^{14}$

The main 'rule' governing Middle Assyrian laws on feminine veiling is laid out right at the beginning of paragraph 40:

The wives of a man, or widows, or any Assyrian women who go out in the main street shall not have their head bare [qaqqassina (la pattu)]. ${ }^{15}$

Here it is made quite clear that veiling was prescribed for appearances in public of married women, even if in the state of widowhood, but also applied to the vaster class of women who were 'Assyrian', i.e. who were recognised as of free status because born to a native family of long standing (of the merchant class or professionally tied to the king). ${ }^{16}$ In sum, the law stated that the presence in public of a native-born and free woman, particularly if of a married status, was to be marked by the presence of a veil on her head.

This custom finds references also in other documents of the same age: thus, for example, a medical text concerning a woman in labour,

13 Texts are given in Roth 1997, 153-94; for a brief presentation, see e.g. Fales 2017, 411

14 CAD P, 218a, both with transitive and reflexive meanings. See also Waetzoldt 1980-83, 202.

15 Roth 1997, 167, MAL A § 40.

16 It is supposed that girls were typically married at age fourteen (Roth 1987, 737). 
whose blocked womb is causing enormous difficulties for her travail, vividly illustrates how the pain she was suffering was stronger than the social conventions to be followed.

Like a warrior in battle, she is cast down in her own blood. Her eyes are diminished, she cannot see, her lips are covered, she cannot open them. [...] Her ears no longer hear, her breast is no longer high, her curls are scattered, She no longer wears the veil, she no longer feels shame. O merciful god Marduk, be present and save her! $!^{17}$

But the same code of conduct regarding married women applied to the circulation on the public street of a 'concubine' (esirtu), who could be living legitimately in the household of a married couple as a secondary sexual companion to the man, when accompanying the main wife:

A concubine who goes about in the main thoroughfare with her mistress must be veiled [pașșunat]. ${ }^{18}$

Another article of the same law collection is very clear on the fact that a concubine could be elevated by a man to the status of a wife, and that this change of condition implied precisely the act of veiling the woman:

If a man would veil his concubine, he shall assemble five or six of his comrades, he shall veil her in their presence, he shall declare "She is my wife": she is his wife [mā aššitī šit iqabbi aššassu šitt]. A concubine who is not veiled in the presence of the people, whose husband did not declare "She is my wife": she is not a wife, she is indeed a concubine. ${ }^{19}$

The unveiled concubine could, however, take on an equal juridical status as a veiled wife if the man had died, leaving her with sons of his. In this case, no passage through 'wifehood' was required, and the sons in common were considered as legitimate heirs of the deceased.

If a man is dead and there are no sons of his veiled wife: the sons of concubines are indeed sons; they shall take the inheritance share [zitta ilaqqeu]. ${ }^{20}$

A further category of women taken into account by the Middle Assyrian laws is that of the qadiltu, of whom it is said:

17 Lambert 1969; see most recently a reedition with colour photograph of this very handsome tablet by F.M. Fales and R. Del Fabbro in Favaro 2017, 239 fn. 184.

18 Roth 1997, 168, MAL A § 40.

19 Roth 1997, 169, MAL A § 41.

20 Roth 1997, 169, MAL A § 41. 
A married qadiltu-woman is to be veiled (when she goes about) in the main street, but an unmarried one is to leave her head bare in the main street, she shall not veil herself. ${ }^{21}$

Now, the professional and social status of this category of women (whose title means 'holy, pure') is uncertain. As may be seen, the qadiltu could be married or not. She is also mentioned alongside the midwife in another Middle Assyrian text, the earliest of the socalled "Harem Edicts" - a set of 23 regulations on fragmentary tablets, bearing royal decrees on the running of the palace and the harem by nine kings over a three-century period. This passage ${ }^{22}$ has suggested that the task of the qadiltu was that of washing or purifying women after they gave birth, but there is no conclusive evidence on the matter and other scholars have rather likened her status to that of a prostitute.

The Middle Assyrian laws also dwell extensively on the veiling of prostitutes (harimtu) ${ }^{23}$ - whereby it is not clear if the reference is to women privately plying their trade for money on the streets, or rather as personnel tied to a state institution, such as the temple or the palace (as may be inferred from their mention in lists of food rations from the same period), and thus possibly participating to rites and ceremonies such as sacred marriages, etc. What is clear, on the other hand, is that the prostitute had no right to wear a veil ${ }^{24}$ and that contravening against this custom carried quite severe physical punishments:

A prostitute shall not be veiled, her head shall be bare. Whoever sees a veiled prostitute shall seize her, secure witnesses, and bring her to the palace entrance. They shall not take away her jewelry, but he who has seized her takes her clothing; they shall strike her 50 blows with rods; they shall pour hot pitch over her head. And if a man should see a veiled prostitute and release her, and does not bring her to the palace entrance, they shall strike that man 50 blows with rods; the one who informs against him will take his clothing; they shall pierce his ears, thread them on a cord, tie it at his back; he shall perform the king's service for one full month. ${ }^{25}$

\section{Roth 1997, 169, MAL A § 41.}

22 Roth 1997, 197, MAL A § 41, decree on entering and leaving the palace: "[...] the midwife (sabsūtu) and the qadiltu [...] shall not go in or go out".

23 The long-established interpretation of the word harimtu as 'prostitute' was at length and vigorously opposed by J. Assante (see e.g. Assante 1998), but it now seems to have been definitely demonstrated (see e.g. Cooper 2006, 2011). See however an indirect reply in Assante 2007, and most recently Budin 2021.

24 As suggested by Cooper this provision would have been conceived for "visually marking the sexually approachable and the unapproachable" $(2016,212)$.

25 Roth 1997, 168, MAL A § 40. 
A further category to which the veil was denied, as illegal, was that of slave women. The punitive provisions in the Middle Assyrian laws in case of infringement are not very dissimilar from the ones seen above for prostitutes - although one may notice that lex talionis (beating and forced labour) was also applied to a man who had not denounced her veiled status.

Slave women shall not be veiled, and whoever would see a veiled slave woman shall seize her, and bring her to the palace entrance. They shall cut off her ears; he who seized her shall take her clothing. If a man should see a veiled slave woman and releases her and not seizes her, and does not bring her to the palace entrance, and they then prove the charges against him and find him guilty, they shall strike him 50 blows with rods; they shall pierce his ears, thread them on a cord, tie it at his back; the one who informs against him shall take his garments; he shall perform the king's service for one full month. ${ }^{26}$

\section{$4 \quad$ Wider Contexts}

Let us now attempt to view these Middle Assyrian laws on women, and specifically on veiling, in their wider historical context, so as to avoid facile judgments and possibly anachronistic conclusions. Not only this law collection, but especially the contemporaneous "Harem Edicts" emanated by the kings (see above), show very harsh provisions and regulations, reaching the point of calculated frightfulness in the punishment of misdemeanours and crimes involving genders or social classes. Since they frequently present the possibility of corporal/capital penalties and of extra-rational means of reaching the truth, such as the oath and the river ordeal, they have even caused scandalised views on the part of some modern interpreters (like Guillaume Cardascia, who described them as "a juridical museum of horrors" in 1969)..$^{27}$

On the other hand, the day-to-day legal documents of the same age (which have recently come to light thanks to archaeological findings) indicate that some crucial rights and legal conditions differed radically from these official norms, and that recourse to pecuniary measures was widespread. How to solve this contradiction? Perhaps the Middle Assyrian laws and the Edicts reflected stricter normative

27 Just to give one example, the following proviso may be quoted: "They shall kill a palace woman who swears] by the name of the god for improper purposes [...], they shall not spare her life" (Roth 1997, 202, § 11). 
codifications applying to the specific moral and intellectual 'climate of the religious and political capital Aššur, whereas the 'everyday' texts reflected the more varied mechanisms of economy and society throughout the kingdom, with its many provinces, diverse geographical landscapes, and mutually intermingling peoples. ${ }^{28}$

However as this may be, family law shows noticeable differences between the Middle Assyrian official collection and the few relevant legal documents of the time. While in the official laws the woman is presented as being fully under the authority of a husband or father (as e.g. in marriage law), various deeds of this time show that women had the capacity to be parties to contracts in the name of their absent spouse, to grant or request loans, to adopt and purchase. This status of Middle Assyrian women thus seems closer to the one visible in earlier Old Assyrian law, where men and women had equal status in marriage law and divorce, in business practice, including the right to sue, and in testamentary and inheritance law.

\section{Conclusions}

So, to conclude, where do we stand on the rigid veiling practices of women illustrated in such great detail within these collections of Middle Assyrian laws and prescriptions? The only comment I feel like offering on the present occasion is that these texts from 1400 $\mathrm{BC}$ stand, for the moment, in splendid isolation. Despite the great abundance of cuneiform documents concerning Assyria - its vast territories and its diverse peoples, its many kings and their military deeds - in the course of the following seven centuries until its final downfall, we have no more evidence of this type and depth at our disposal regarding the use and limitations of female veiling..$^{29}$ Thus, to answer a hypothetical question: Were Assyrian women veiled? They were certainly veiled at times, even according to specific protocols of social condition and personal status, but we cannot say at present whether the relevant prescriptions had wide or limited validity, and whether they applied equally all through the following centuries of Assyrian domination, or not.

29 The main evidence from Assyria of the first millennium BC as regards veiling concerns non-Assyrian women, as represented in the palatial bas-reliefs: either deportees from various (usually Levantine) captured cities, or Arab women. See D. Nadali in this volume. 


\section{Bibliography}

Assante, J. (1998). “The kar.kid/harimtu, Prostitute or Single Woman?”. UgaritForschungen, 30, 5-94.

Assante, J. (2007). "What Makes a 'Prostitute' a Prostitute? Modern Definitions and Ancient Meanings". Historiae, 4, 117-32.

Budin, S.L. (2021). Freewomen, Patriarchal Authority, and the Accusation of Prostitution. New York.

$\mathrm{CAD}=$ The Assyrian Dictionary of the Oriental Institute of the University of Chicago (1964-2011). Chicago; Glückstadt.

Cardascia, G. (1969). Les lois assyriennes. Paris.

Cavigneaux, A. (1980-83). "Lexikalische Listen". Reallexikon der Assyriologie, 6, 609-41.

Çığ, M. (1988). "Atatürk and Beginnings of Cuneiform Studies in Turkey". Journal of Cuneiform Studies, 40(2), 211-16. https://doi.org/10.2307/1359663.

Civil, M. (1994). The Farmer's Instruction. A Sumerian Agricultural Manual. Barcelona.

Cooper, J.S. (2006). “Prostitution”. Reallexikon der Assyriologie, 11, 12-21.

Cooper, J.S. (2016). "The Job of Sex. The Social and Economic Role of Prostitutes in Ancient Mesopotamia". Lion, B.; Michel, C. (eds), The Role of Women in Work and Society in the Ancient Near East. Boston; Berlin, 209-27.

Fales, F.M. (2001). L'impero assiro. Storia e amministrazione (IX-VII sec. a.C.). Roma; Bari.

Fales, F.M. (2017). “Assyrian Legal Traditions”. Frahm, E. (ed.), A Companion to Assyria. Malden (MA), 398-422.

Favaro, A. (ed.) (2017). Signs Before the Alphabet. Journey to Mesopotamia at the Origins of Writing. Florence. ${ }^{30}$

Lambert, W.G. (1969). "A Middle Assyrian Medical Text". Iraq, 31(1), 28-39. https://doi.org/10.2307/4199863.

Postgate, J.N. (1992). "The Land of Assur and the Yoke of Assur". World Archae-

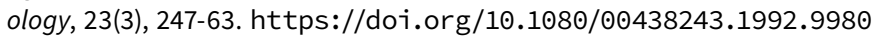
178.

Radner, K. (2015). Ancient Assyria. A Very Short Introduction. Oxford.

Roth, M. (1987). "Age at Marriage and the Household: A Study of Neo-Babylonian and Neo-Assyrian Forms". Comparative Studies in Societies and History, 29(4), 715-47. https://doi.org/10.1017/s0010417500014857.

Roth, M. (1997). Law Collections from Mesopotamia and Asia Minor. Atlanta.

Schmidt, J. (2010). "Fritz Rudolf Kraus in Istanbul (1937-1949) and the Development of Ancient Near Eastern Studies in Turkey". Bibliotheca Orientalis, 67(1-2), 5-21. https://doi.org/10.2143/bior.67.1.2052734.

Stol, M. (1995). "Women in Mesopotamia". Journal of the Economic and Social History of the Orient, 38(2), 123-44. https://doi. org/10.1163/1568520952600524.

Stol, M. (2016). Women in the Ancient Near East. Boston; Berlin.

Streck, M.P. (2010). "Großes Fach Altorientalistik. Der Umfang des keilschriftlichen Textkorpus". Hilgert, M. (Hrsg.), Altorientalistik im 21. Jahrhundert. Selbstverständnis, Herausforderungen, Ziele. Berlin, 35-8.

30 Catalogue entries in this volume are by F.M. Fales and R. Del Fabbro. 
Tsevat, M. (1975). "The Husband Veils a Wife". Journal of Cuneiform Studies, 27(4), 235-40. https://doi.org/10.2307/1359326.

Van der Toorn, K. (1995). "The Significance of the Veil in the Ancient Near East". Wright, D.P. et al. (eds), Pomegranates and Golden Bells. Studies in Biblical, Jewish, and Near Eastern Ritual, Law, and Literature in Honor of Jacob Milgrom. Winona Lake, 327-40.

Van der Toorn, K. (1996). Family Religion in Babylonia, Syria, and Israel. Continuity and Change in the Forms of Religious Life. Leiden; New York; Köln.

Waetzoldt, H. (1980-83). “Kopfbedeckung, A. Philologisch". Reallexikon derAssyriologie, 6, 197-203. 


\title{
To See or Not to See. The Issue of Visuality in Ancient Near Eastern Art Images of Queens, High Priestesses, and Other Elite Women in the Third Millennium BC
}

Davide Nadali

Sapienza Università di Roma, Italia

\begin{abstract}
The presence of veil usually characterises and defines women in ancient Near Eastern societies: indeed, the use of veil has been usually interpreted as to define both gender and role of the represented characters. But can the veil be so exclusively targeted? The analysis of the presence or even the absence of the veil needs to be contextualised: this contribution offers a short consideration on the use of the veil by women in ancient Mesopotamian and Syrian societies, trying to single out moments and circumstances, showing how images of women with veil are not so clearly identifiable and detectable as pointing to only one category, an exclusive role and a special position.
\end{abstract}

Keywords Syria. Mesopotamia. Iconography. Women. Ebla. Mari. Assyria.

Summary 1 Introduction. - 2 The Evidence of the Use of the Veil. - 3 Matter of Methods. - 4 Ebla and Mari in the Third Millennium BC. - 5 The Evidence of the 1st Millennium BC. -6 Conclusions.

\section{Introduction}

The question of visuality encompasses different aspects of the studies of visual culture, mostly the accessibility of images, specifically in ancient societies: central points of the research in the field of images, in fact, refer to the 
reconstruction of the place where pictures were originally displayed (if they were) ${ }^{1}$ and, as a consequence, the understanding of the type of addressees who were supposed to see the pictures, interact with them and, eventually, to be affected by their presence in the space. However, in this contribution, the question of visuality is mostly centred on the analysis of images themselves and the characters they portray, focusing on the use and presence of veils and shawls that had the function of covering, i.e. hiding, parts of the bodies of the figures, thus creating a kind of separation and a diaphragm that worked as a signal (a social marker and indication of the role) and an element of respect. The veil is thus a screen that projects specific meanings and onto which several implications are projected, mostly by the analysts when they try to interpret the office and position of the figures who wear a veil on the head. In this respect, the visuality is here intended as the visibility of the veil and, as a consequence, the partial invisibility of the body of the portrayed figure.

\section{The Evidence of the Use of the Veil}

In an investigation on the use and function of the veil in the Ancient Near East, which news and information can be collected from art? Provocatively, one could simply state: Nothing. On the other hand, images show the use of veils in different contexts, mainly associated with female figures. This particular attitude and occurrence seem actually to corroborate that the use of the veil is mainly, if not exclusively, a female matter with the too-easy and sometimes simplistic comparison with modern and contemporary societies in the Near East. But is it exactly like that? This automatic mechanism of comparison, specifically when it is limited to religious milieu, might in fact minimise the specificities of the ancient Near Eastern contexts and, at the same time, create superfetation with the addition of superfluous considerations that pretend to be true and correct because they are based on the analogy and contiguity of places.

Indeed, male figures of kings, officials, priests, and deities are not represented with their head covered with a shawl, but they are either bare-headed or wear headgear; statues of kings, in particular, usually are bare-headed, while bas-reliefs and representations on cylinder seals normally show kings with headgear (tiara, head-

1 This aspect, for example, can be questioned in the analysis of the ancient foundation deposits that, beyond cuneiform tablets and documents, also included clay or bronze figurines: because of their nature and function, those images were not supposed to be seen, at least physically: of course, those images were instead, metaphorically, seen by the gods (particularly in the case of foundation deposits of temples) and the future kings who, as the inscriptions often report, were in fact the addressees (Winter 2000). 
bands etc.). Can we therefore suppose that statues of kings and deities were adorned with cloth tiaras that were purposely made and put on the heads? The perishable nature of the materials did not survive in archaeological records, but ancient texts document the clothing of ancient statues on the occasion of special events and ceremonies and because of this use and tradition, clothes of statues needed to be periodically renewed. ${ }^{2}$

Speaking of the use of veils in the Ancient Near East starting from and based on the iconographic evidence can therefore be problematic: on the one hand, one has to take into consideration that this might be an argumentum e silentio, that is images are few and mostly belonging to a specific category (i.e. the representation of women), but that this corpus of evidence might not exactly correspond to the reality of facts and events; on the other, I think that one of the most problematic issues of the study of the use of the veil in Ancient Near Eastern societies actually pertains to the methodology of our disciplines, our formulation of the question, and, finally, to the conclusion we can reach from so limited a number of images that are even inconsistent.

Concerning methodology, the occurrence of veils associated with female figures constrained the analysis to the field of gender studies: What was the role of women with veils? When and why did women wear the veil? The presence of the veil has been usually interpreted as a very special attribute that can finally help identifying the function and role of the women: however, as the images themselves show, the conclusion that has been reached so far is not necessarily erroneous, but I think it is at the same time far from being the only interpretation we can advance.

For that reason, I think that a different approach is needed: first of all, images must be seen in their original contexts, that is the images of women with shawls cannot be decontextualised and used in a general catalogue of occurrences as if one wishes to compile a comprehensive list of all women with veils. This last approach however is not, in principle, an incorrect operation, but one runs the risk of simply presenting the cases without a discussion, putting them at the same level and thus proposing comparisons that are misleading and, as already mentioned, inconsistent with the nature and type of the visual documents at our disposal.

Based on the use of the veil in other ancient societies and looking at modern and contemporary societies in the Near East, it has also been assumed that the presence of the veil mostly concerns religion and is strictly related to religious tradition and cults. Even in this case, is it exactly like that? Can we conclude that all women wearing the veil are somehow linked to religious affairs or have a position in cults and rites?

2 See for example the evidence at Ebla (Biga 2021) and in Assyria (Villard 2013). 


\section{$3 \quad$ Matter of Methods}

The question of the veil is in fact more complex and I think that the visual evidence at our disposal is not sufficient to present clear or unique interpretations and conclusions: therefore, many questions are still open and need an answer that could never be found - at least not unanimously for all questions and evidence. Giving (sure and valid) answers is a difficult task that goes beyond the scope of this short reflection, but I would like to point out the problems of the interpretation of an apparently simple issue that in the end unveils many different aspects. In this respect, I am in fact convinced that the study of the use of the veil in Ancient Near Eastern societies needs to be contextualised on one hand, and decolonised on the other: contextualisation is the only process that can in fact explain the use of the veil starting from the place where images were displayed and used; decolonisation marks the turning point in the analysis because it frees the question of the veil from the categories of our modern and contemporary world that are not necessarily valid for ancient societies and that, on the contrary, create a fictitious relationship and an unbalanced comparison, projecting the present onto the past and, conversely, using the past to understand and judge the present.

The study of the question of veiling needs a multi- and cross-disciplinary system of reference, because the exclusive choice of either the gender or religious approach might lead to a partial comprehension of the phenomenon: choosing between the two is not necessarily a wrong approach, but it surely offers a limited vision of the complexity of the reality and we therefore run the risk of making ancient images say what we wish them to convey and express, instead of making images themselves speak on their own. This possible (always latent) risk causes mistaken interpretations and evaluations of the data that are categorised according to our canons and taxonomies: therefore, the study of the use of the veil must be founded on a solid cultural background that encompasses gender studies, ancient religion, anthropology, sociology, and political studies to get a more comprehensive and exhaustive picture that does not point to a selected and too limited detailed aspect: when dealing with images, this is precisely the method of making history of art where images are not just illustrations of history, but they contribute to writing history in all its aspects, thus presenting an inclusive overview that does not pretend to be absolutely true, but at least considers all possible implications in the domain of sociological, religious, gender, and political studies.

To exemplify what I intend, by showing what I called the inconsistency of images, the selection and presentation of some pictures, taken from different contexts, point to the similarities (as if one follows a decontextualised approach), on the one hand, and the differences (applying the contextualised approach that discloses the specificities of each case), on the other. 


\section{Ebla and Mari in the Third Millennium BC}

The two female figures from Ebla and Mari are very typical of what corresponds to the so-called type of 'woman with veil' [figs 1-2]: what do they represent? Surely, two seated women. What does the presence of the veil add to the interpretation? Commonly, because of the presence of the veil, the two characters are interpreted as priestesses, thus the veil connotes a religious milieu. Based on this commonly accepted interpretation, we could therefore conclude that all female figures with a veil on their head are priestesses, connoting the images not only within a religious sphere, but actually precisely pointing to a specific duty and role in the administration of the religion.

However, if one looks at representations of priestesses in the Mesopotamian art of the third millennium BC, it is immediately clear that the figures are bare-headed with their hair loose: on the contrary, when hair is tied up, these figures can be interpreted as members of the ruling class, queens or princesses, and they are represented standing (statues in the round) or seated (in cylinder seals in scenes with other women or in the common scenes of banquet). ${ }^{3}$ As a matter of fact, the most common Mesopotamian priestess, Enkheduanna, Sargon's daughter, is represented bare-headed with her hair loose. ${ }^{4}$

We are therefore facing two opposite situations and interpretations: the two veiled figures from Ebla and Mari have been interpreted as priestesses, while priestesses in a Mesopotamian context are usually identified as bare-headed figures with loose hair. Therefore, it seems that the veil has no typical religious connotation or, at least not always: it depends on the context in which the images were used and displayed and, probably, the situation they wanted to convey and signify. In particular, this difference actually reflects a geographical distinction with two realities, Syria and Mesopotamia, in comparison: in this respect, it seems that Mari, usually associated with and closer to the Mesopotamian cultural tradition, is here referring to a more properly Syrian practice and again it is quite interesting that this happens in the context of the role and representation of women in the art of the third millennium BC. ${ }^{5}$ At the same time, exactly as the reasoning at the beginning about statues in the round, can we in fact exclude that statues of priestesses with hair loose were covered with cloth veils once they were placed, for example, within the

3 For a categorisation and distinction of the roles, based upon the iconographic evidence of ancient Mesopotamia in the third and second millennium BC see the analysis by Suter 2007; 2016; 2017.

4 Winter 1987; Suter 2017, 345, 355.

5 On the political role of women in Syria, see Nadali 2014. On the cultural iconographic tradition of Mari, see Pinnock 2014. See also Suter 2018 on the role and participation of women in social events, such as feasting. 
Davide Nadali

To See or Not to See. The Issue of Visuality in Ancient Near Eastern Art

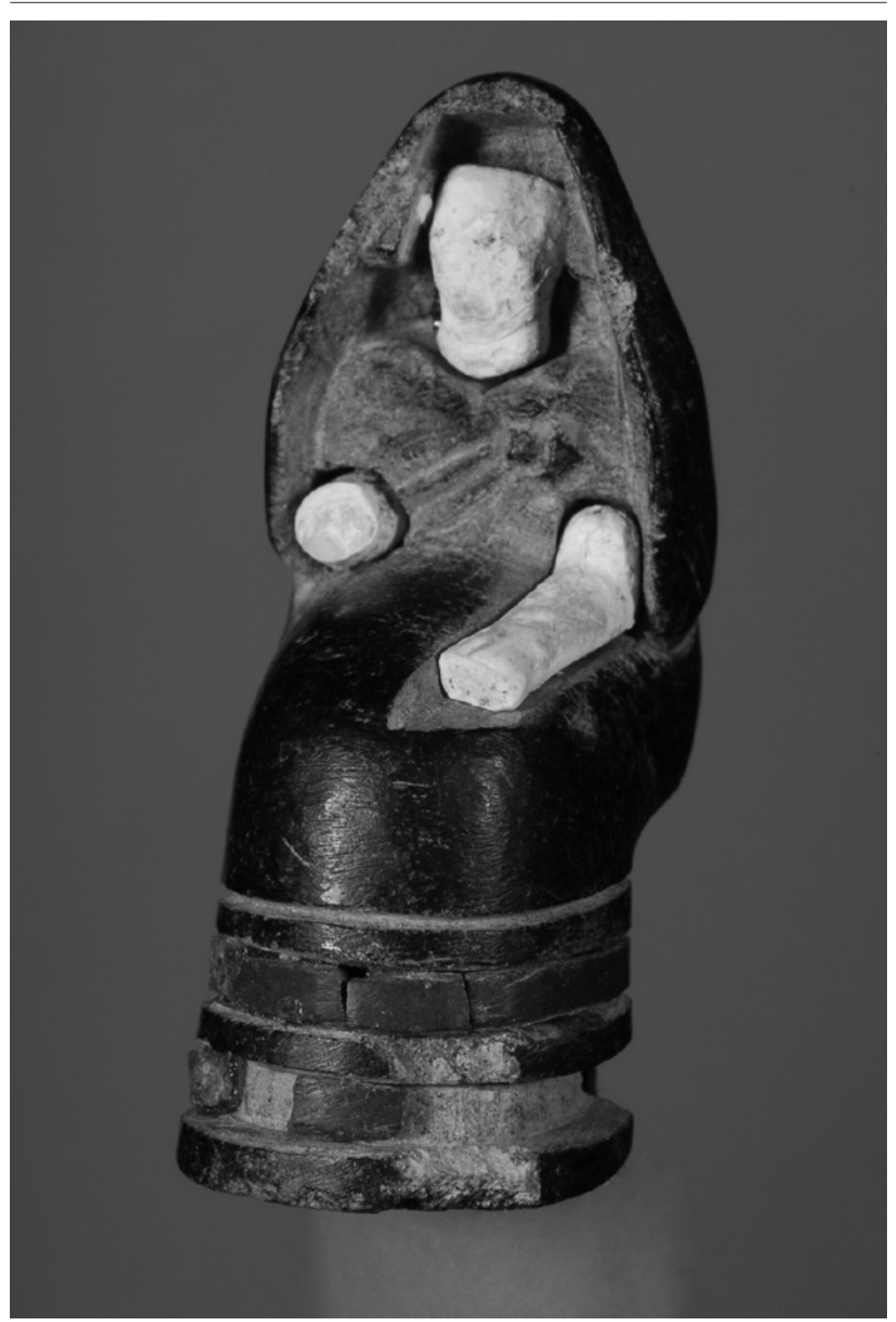

Figure 1 Statuette of seated priestess from Ebla. @ Missione Archeologica Italiana in Siria 
Davide Nadali

To See or Not to See. The Issue of Visuality in Ancient Near Eastern Art

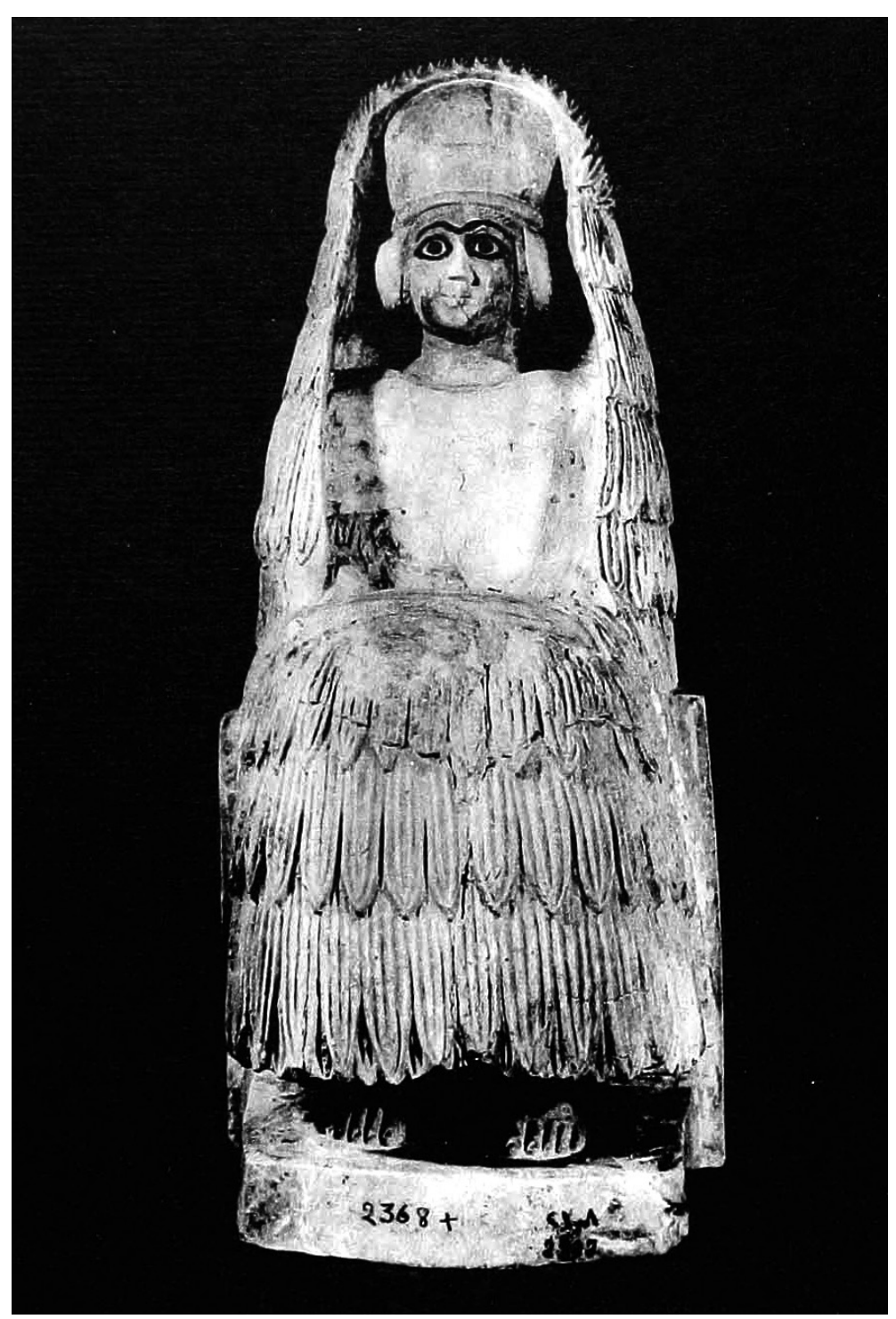

Figure 2 Statue of seated priestess from Mari (after Parrot 1967, pl. L) 


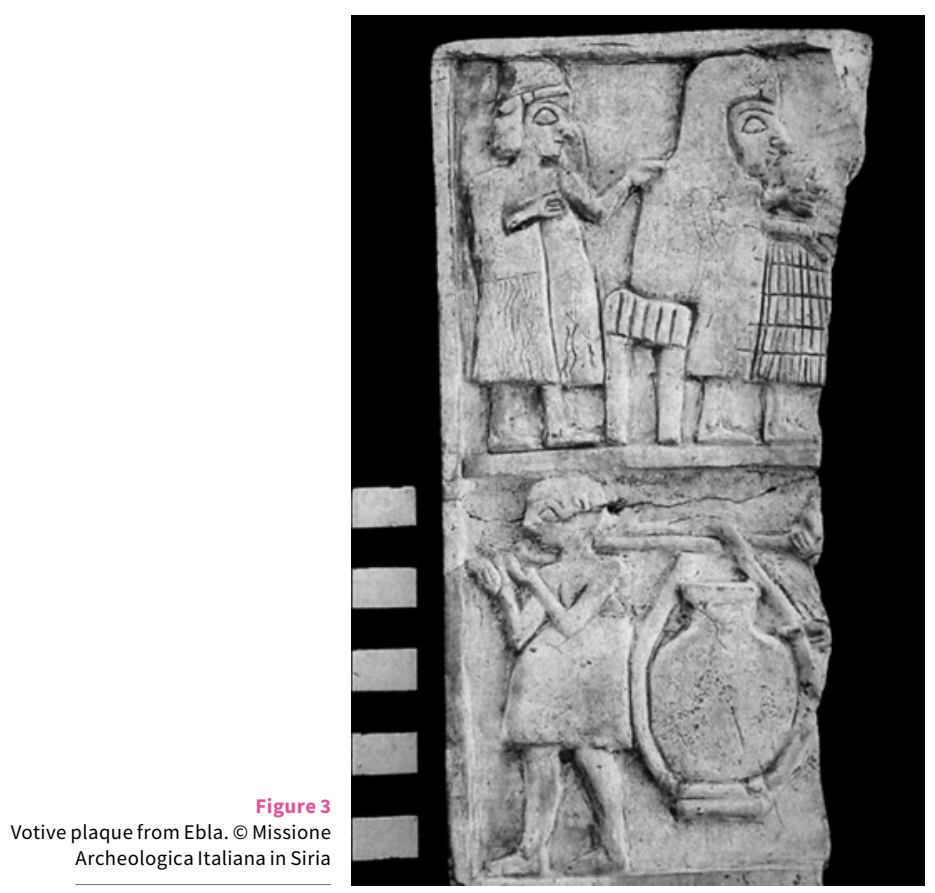

temple and facing the statue of the deity, or on the occasion of special ceremonies and rites?

Conversely, some images do show women with a veil and these can be interpreted as queens or members of the ruling class: are those women just wearing the veil because of a question of fashion or because they at the same time fulfil a religious duty, maybe in front of the deity or on the occasion of a religious festival or ceremony? A sculpted plaque shows a female seated figure with a veil in front of a deity: thanks to the inscription, she might be identified as Nidupae's wife, whose name appears next to her. According to Claudia Suter, ${ }^{6}$ she might alternatively be the daughter of Šaratigubisin, in her role as a high priestess. In this case, a member of the ruling class - exactly as it happened with Enkheduanna, Sargon's daughter - also performs the role of high priestess that is specifically singled out by the use of the veil while seated in front of the deity. ${ }^{7}$

6 Suter 2017, 347-8, fig. 4.

7 Even if few, the pictures of Enkheduanna show that, even when performing cultic actions and offerings, the high priestess of Nanna at Ur is always bare-headed, and she 


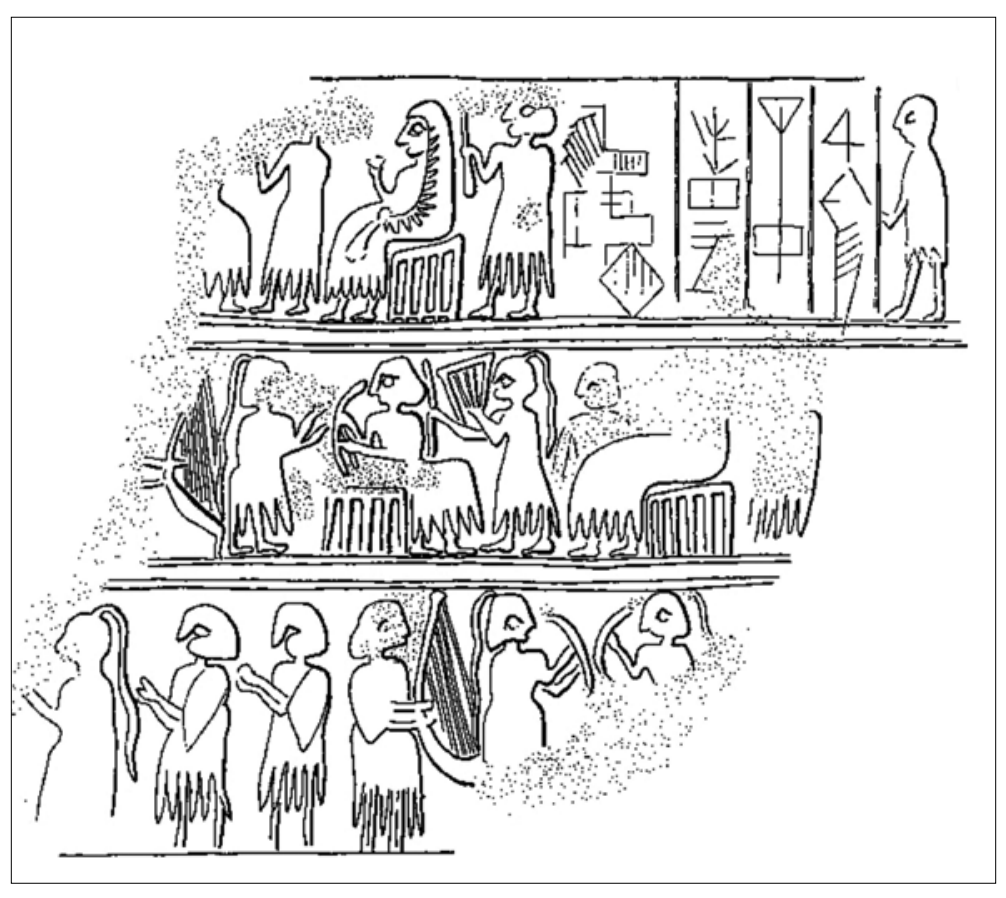

Figure 4 Seal impression from Mari (after Beyer 2007, fig. 4c)

Other pictures enter into the same category of women with a veil, who, starting from the above-mentioned sculpted plaque, might be interpreted as either queens or members of the ruling class in the duty of priestess or, more probably, while attending a religious ceremony. A plaque from the Royal Palace G of Ebla depicts a seated female figure [fig. 3], ${ }^{8}$ her head covered with a shawl: found in the palace, the figure can more probably be identified as the queen of Ebla while acting - apparently banqueting because she holds a cup in her hand - on a special occasion, maybe a festival or a ritual, such as the Ritual of Kingship that was regularly performed by the royal couple within the city in the temple of Kura, and outside the city in the mausoleum in the city of Nenaš, which belonged to the ancient kingdom of Ebla in the third millennium BC. ${ }^{9} \mathrm{~A}$ very similar image is preserved

only wears a band on the forehand.

8 See Romano 2015.

9 In this respect, it is interesting to point out that, during the ceremony of the ritual, the queen has to dress up and, more specifically, to cover her head with a veil (Romano 2015, 36-7; Pinnock 2016, 103-4; for the text of the ritual see Fronzaroli 1993). 
Davide Nadali

To See or Not to See. The Issue of Visuality in Ancient Near Eastern Art

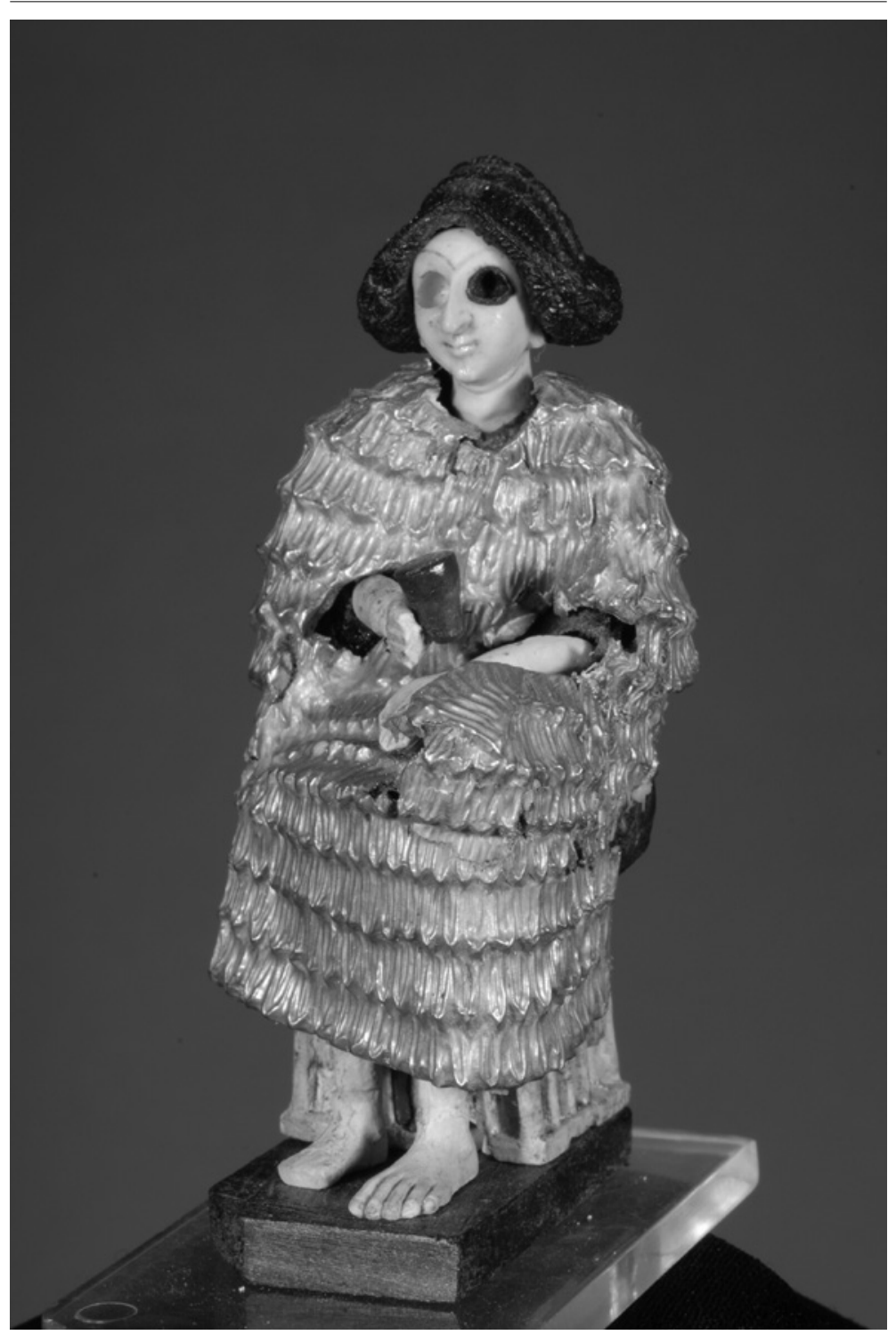

Figure 5 Seated statuette of the queen Dusigu from Ebla. @ Missione Archeologica Italiana in Siria 
Davide Nadali

To See or Not to See. The Issue of Visuality in Ancient Near Eastern Art

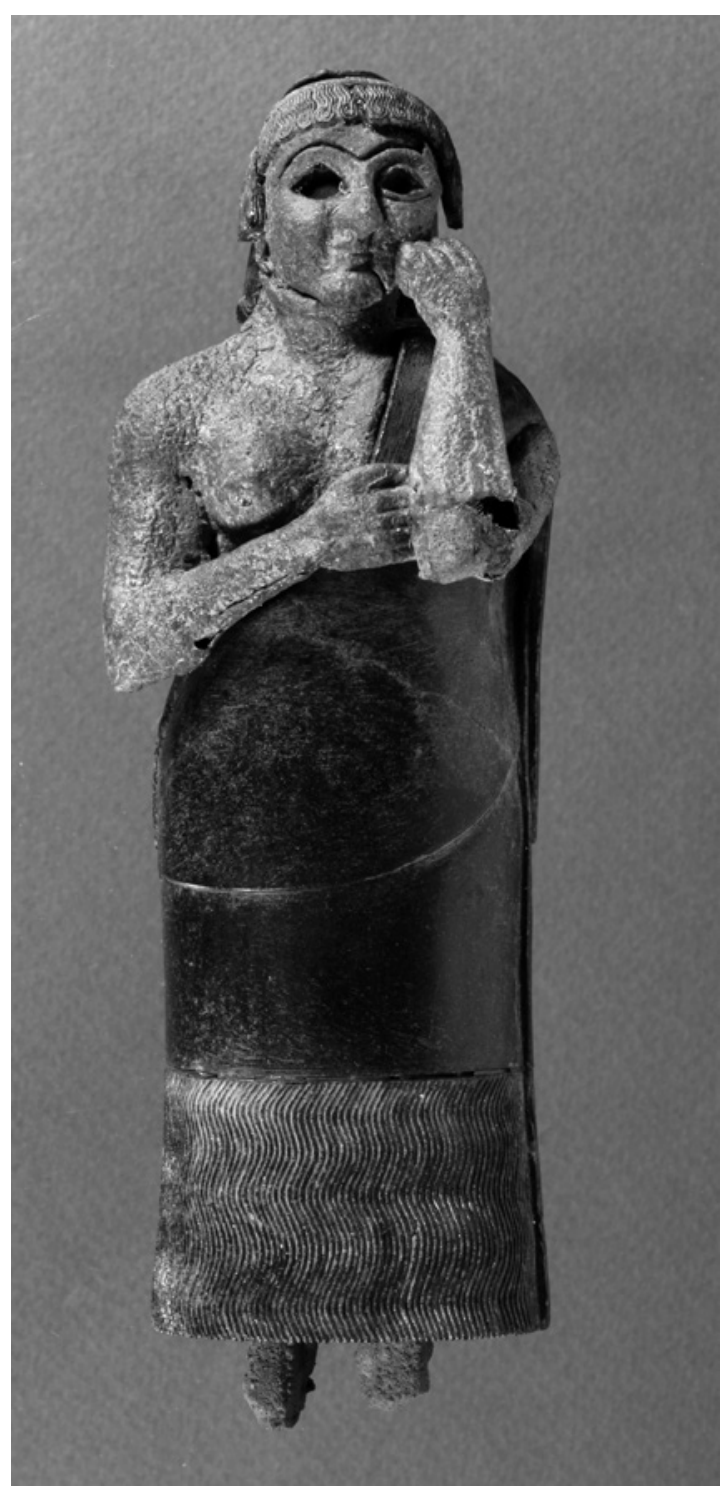

Figure 6 Standing statuette of the princess Tabur-Damu from Ebla. (c) Missione Archeologica Italiana in Siria 
Davide Nadali

To See or Not to See. The Issue of Visuality in Ancient Near Eastern Art

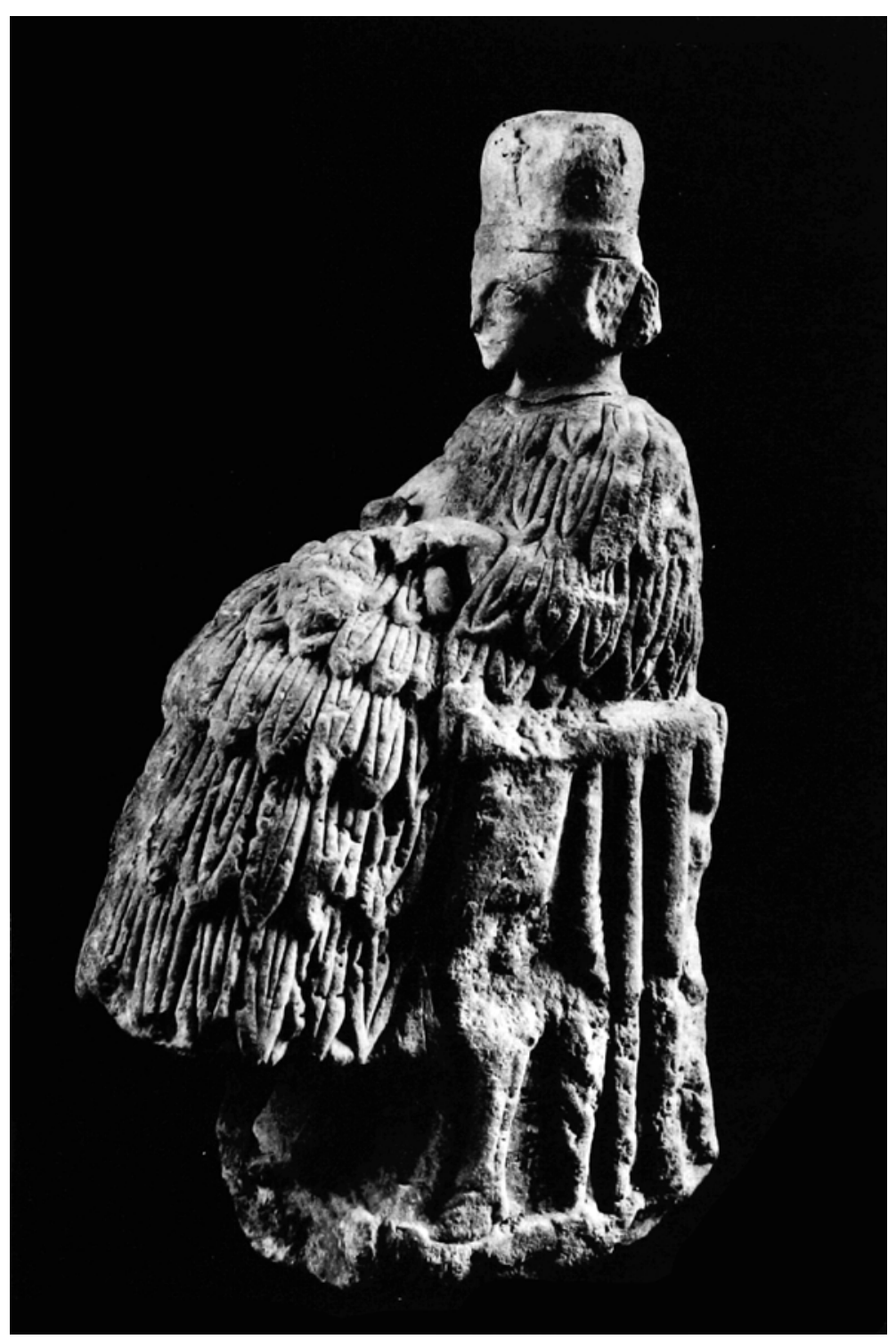

Figure 7 Statue of seated female woman with polos from Mari (after Parrot 1956: pl. XXXVII) 
Davide Nadali

To See or Not to See. The Issue of Visuality in Ancient Near Eastern Art
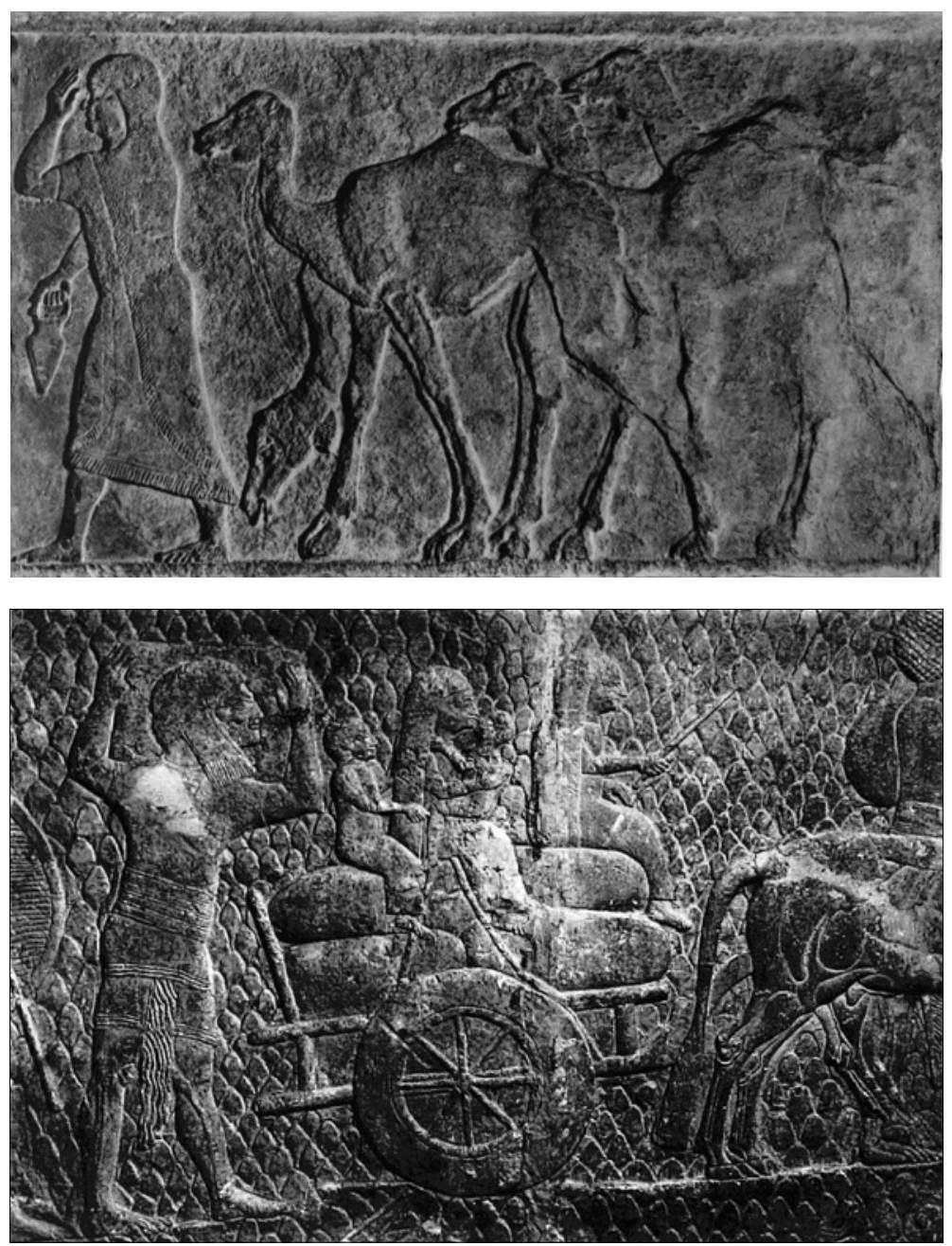

Figure 8 Arab woman, prisoner of the Assyrians (after Barnett, Falkner 1962, pl. XXVI)

Figure 9 Detail of slabs 9 and 10, room XXXVI of the South-West Palace of Sennacherib (after Barnett, Bleibtreu, Turner 1998, pl. 333) 


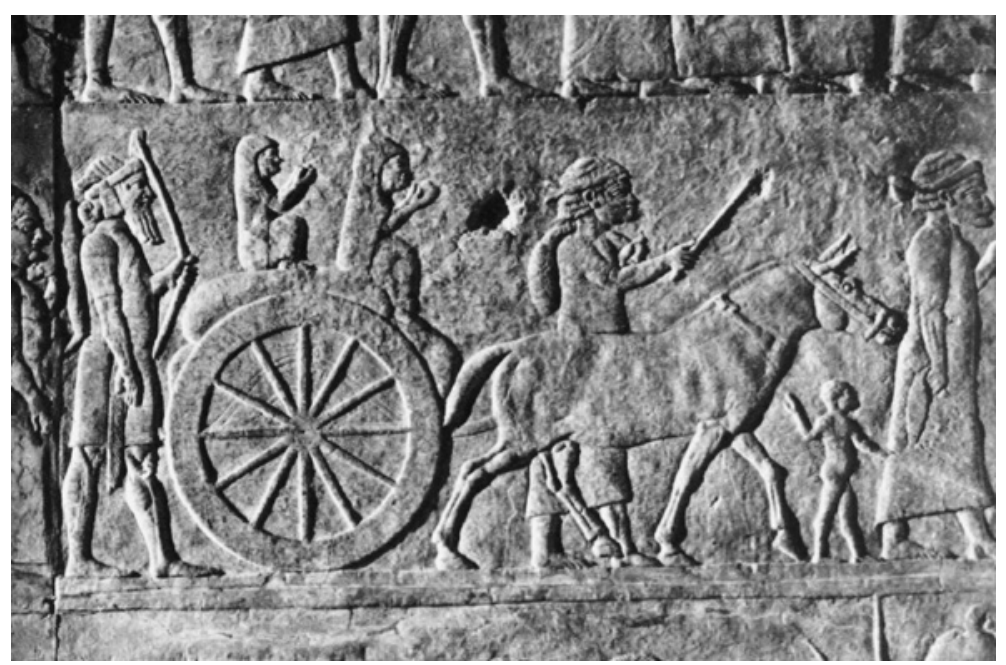

Figure 10 Detail of slab 9, room F of the North Palace of Ashurbanipal (after Barnett 1976, pl. XIX)

on a door sealing from Mari [fig. 4], depicting a seated veiled woman while banqueting - she also holds a cup in her right hand. The cuneiform cartouche clarifies that the seal belonged to the wife of the EN (king) of Mari. Therefore, if one thinks of the two female statue figures from Ebla and Mari, one could thus suggest that they are two queens or members of the ruling class wearing the veil because they are represented and connoted here as attending to or officiating at a religious moment. In fact, the woman of Mari also wears a polos that is usually associated with an official specific role such as a ritual activity and involvement of the female royal members. ${ }^{10}$ Looking at the visual documents from Ebla, when the queens are not directly involved in ritual activity, they neither wear a headgear nor do they cover their head with a veil [figs 5-6]. ${ }^{11}$ At Mari, again, a seated female figure wears the polos, but not the veil [fig. 7]: these examples show that the combination is multiple and polos and veil are not always associated, but this probably happens on the occasion of special contexts, when the female character is directly involved in official religious and cultic activities.

10 Pinnock 2014, 677-8.

11 See the representation of the court ladies, the queen Dusigu, and the princess Tabur-Damu, in the so-called standard of the queen, as interpreted and reconstructed by Matthiae 2009. 


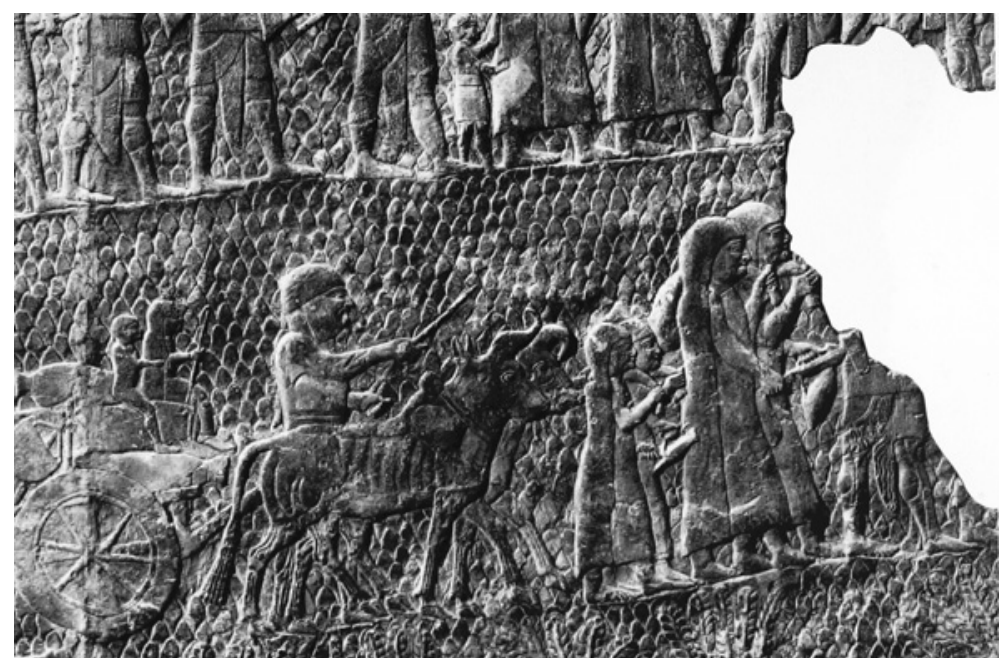

Figure 11 Detail of slabs 8 and 9, room XXXVI of the South-West Palace of Sennacherib (after Barnett, Bleibtreu, Turner 1998, pl. 352)

\section{The Evidence of the 1st Millennium BC}

In a completely different context, women with their head covered with a shawl occur in the Assyrian palace bas-reliefs of Tiglath-Pileser III, Sennacherib, and Ashurbanipal [figs 8-10]. ${ }^{12}$ Differently from the examples of the third millennium BC so far analysed, the Assyrian wall palace reliefs represent the aftermath, that is processions of prisoners - among them women - coming out from the cities conquered and sacked by the Assyrian army. With the sole exception of the basrelief of Tiglath-Pileser III (depicting an Arab queen), the women in the bas-reliefs of Sennacherib and Ashurbanipal could in fact be labelled as 'normal' women, that is they are not members of royal families and the ruling class: in this context, the veil does not point to type and function, but it simply denotes a female individual wearing a typical dress, independently of the age and the social position [fig. 11]. In the Assyrian bas-reliefs the veil seems to (exclusively?) operate as a gender marker: Does it also have a geographical function? The women with the veil in Tiglath-Pileser III and Sennacherib bas-reliefs have a Western origin, Arabia and Southern Levant; the scene from Ashurbanipal palace belongs to the series of wall panels dedicated to the depiction of the Elamite wars in the East. However, the Arab women in Ashurbanipal bas-reliefs depicting the Arab 


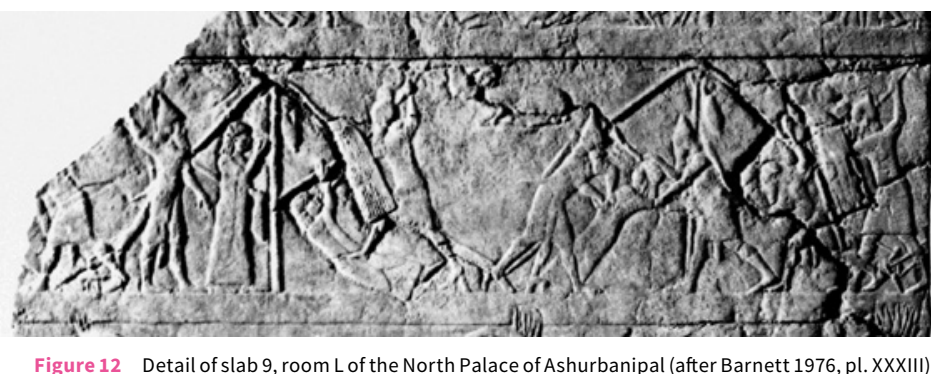

Figure 12 Detail of slab 9, room L of the North Palace of Ashurbanipal (after Barnett 1976, pl. XXXIII)

campaign in Room L of the North Palace at Nineveh are represented bare-headed [fig. 12]. ${ }^{13}$

\section{Conclusions}

Images of women with veils are not largely documented: with such little evidence at our disposal, it is difficult and even misleading to formulate apodictic conclusions. As reminded at the beginning, the question is still open and I think that open interpretations, rather than fixed and definitive statements, can be advanced only from a contextual approach because images, even within the same culture and period - such as the examples from Ebla and Mari show, are inconsistent and they do not allow for a categorisation by types. The use of images explains the reason for the presence or absence of the veil and even the religious sphere and cultic activity is not a good and perfect common denominator.

Needless to say, the question is still open and research should take into account the poor evidence from visual documents (numbers of examples) on the one hand, and silent data, such as the use of fabric shawls that are no longer visible, on the other. To overcome these evident limits, we need to establish the research upon methods that favour a cross-disciplinary investigation which combines different aspects without making one prevail over another: in particular trying to avoid the preferential interpretative choice of what seems easier or feasible just because it is closer to our feelings, perception, and understanding of the ancient Near Eastern societies as an early mir-

13 Indeed, Arab women in the representations from Room L in the North Palace of Ashurbanipal receive a very violent special treatment that is in fact unusual in the Assyrian visual documentation and this probably depends on the role women had in Arab society (Nadali 2004, 73; Dubovský 2009). One could thus conclude that the veil, in Assyrian documentation, mostly works as a gender marker, without any implication on the role and social characterisation of the female subject. 
ror that reflects and recalls social aspects of the modern and contemporary Near Eastern world.

\section{Bibliography}

Barnett, R.D. (1976). Sculptures from the North Palace of Ashurbanipal at Nineveh (668-627 BC). London.

Barnett, R.D.; Bleibtreu, E.; Turner, G. (1998). Sculptures from the Southwest Palace of Sennacherib at Nineveh. London.

Barnett, R.D.; Falkner, M. (1962). The Sculptures of Aššur-nașir-apli II (883-859 B.C), Tiglath-pilesar (745-727 B.C.), Esarhaddon (681-669 B.C.) from the Central and South-West Palaces at Nimrud. London.

Beyer, D. (2007). "Les sceaux de Mari au Ille millénaire. Observations sur la documentation ancienne et les données nouvelles des Villes I et II". Akh Purattim, 1,231-60. https://doi.org/10.4000/books.momeditions. 3863.

Biga, M.G. (2021). "Some Remarks on Textiles and Gender in the Ebla Texts of the Third Millennium BCE". Harlow, M.; Michel, C.; Quillien, L. (eds), Textiles and Gender in Antiquity from the Orient to the Mediterranean. London, 153-62.

Dubovský, P. (2009). "Ripping Open Pregnant Arab Women. Reliefs in Room L of Ashurbanipal's North Palace". Orientalia, 78(3), 394-419.

Fronzaroli, P. (1993). Archivi Reali di Ebla. Testi XI. Testi rituali della regalità (Archivio L.2769). Roma.

Matthiae, P. (2009). "The Standard of the Maliktum of Ebla in the Royal Archives Period”. Zeitschrift für Assyriologie und vorderasiatische Archäologie, 99(2), 270-311. https://doi.org/10.1515/za.2009.008.

Nadali, D. (2004). "La Campagna di Assurbanipal contro gli Arabi. Proposta di lettura delle dinamiche di una battaglia in campo aperto". Studi Miceneied Egeo-Anatolici, 46, 59-78.

Nadali, D. (2014). "Family Portraits. Some Considerations on the Iconographical Motif of the 'Woman with Child' in the art of the Third Millennium BCE". Marti, L. (ed.), La famille dans le Proche-Orient ancien. Réalités, symbolismes, et images. Proceedings of the 55th Rencontre Assyriologique Internationale at Paris 6-9 July 2009. Winona Lake, 227-39.

Parrot, A. (1956). Mission archéologique de Mari I. Le temple d'Ishtar. Paris.

Parrot, A. (1967). Mission archéologique de Mari III. Les temples d'Ishtarat et de Ninni-Zaza. Paris.

Pinnock, F. (2014). "The Image of Power at Mari between East and West". Syria supplément, 2, 675-89.

Pinnock, F. (2016). "Royal Images and Kingship Rituals in Early Syrian Ebla. A Multi-Faceted Strategy of Territorial Control in EBIVA North Inner Syria". Zeitschrift für Orient-Archäologie, 9, 98-116.

Reade, J.E. (1998). "Assyrian Illustrations of Arabs". Phillips, C.S.; Potts, D.T.; Searight, A. (eds), Arabia and Its Neighbours. Essays on Prehistorical and Historical Developments presented in Honour of Beatrice de Cardi. Turnhout, 221-32.

Romano, L. (2015). "The Queen and the Veil. A Note about the Eblaic Votive Plaque". Studia Eblaitica, 1, 33-42. 
Suter, C.E. (2007). "Between Human and Divine. High Priestesses in Images from the Akkad to the Isin-Larsa Period". Feldman, M.; Cheng, J. (eds), Ancient Near Eastern Art in Context. Studies in Honor of Irene J. Winter. Boston, 315-59.

Suter, C.E. (2016). "Images of Queens, High Priestesses, and Other Elite Women in Third-Millennium Mesopotamia". Budin, S.L.; Turfa, J.M. (eds), Women in Antiquity. Real Women Across the Ancient World. Abingdon, 35-47.

Suter, C.E. (2017). "On Images, Visibility, and Agency of Early Mesopotamian Royal Women”. Feliu, L.; Karahashi, F.; Rubio, G. (eds), The First Ninety Years. A Sumerian Celebration in Honor of Miguel Civil. Boston, 337-62.

Suter, C.E. (2018). "Feasting and Elite Women in Early Mesopotamia. A Contribution from the Visual Record". KASKAL, 18, 139-54.

Villard, P. (2013). "Les textiles néo-assyriens et leur couleurs”. Michel, C.; Nosch, M.-L. (eds), Textile Terminologies in the Ancient Near East and Mediterranean from the Third to the First Millennia BC. Oxford, 388-99.

Winter, I.J. (1987). "Women in Public. The Disk of Enheduanna, the Beginnings of the Office of EN-Priestess and the Weight of Visual Evidence". Durand, J.M. (ed.), La femme dans le Proche-Orient antique. Compte rendu de la XXXIIIe Rencontre Assyriologique Internationale. Paris, 189-202.

Winter, I.J. (2000). "Babylonian Archaeologists of The(ir) Mesopotamian Past". Matthiae, P. et al. (eds), Proceedings of the First International Congress of the Archaeology of the Ancient Near East (Rome, 18-23 May 1998). Rome, 1787-800. 


\title{
The Practice of Veiling as an Expression of the Moral Behaviour of Women and Their Social Status in the Qur'an
}

Karl Prenner

Universität Graz, Österreich

\begin{abstract}
Since the Qur'an has been revealed in a very specific historical and cultural context with distinct social conditions, the Qu'ranic regulations for concealment and veiling are investigated using the appropriate terminology. On the one hand, this approach shows how sociocultural conditions changed the Ancient Arabian dress code to promote moral attitudes and social status. On the other hand, it pinpoints concrete events during the lifetime of the Prophet Muhammad that triggered the call for concealment and made veiling part of the social and legal system of Muslim societies.
\end{abstract}

Keywords Qur’an. Shari’a. Hijab. Jilbab. Khimar. Veil. Zîna.

Summary 1 Introduction. - 2 Surah 24, 30-31. - 3 Surah 33, 53. - 4 Surah 33, 59. -5 Conclusion.

\section{Introduction}

The ongoing and highly controversial debate about the veiling of women is by no means exclusive to the issue of integration within a European context, where conflicting sociocultural views, particularly in the area of religious liberty, are predominant. Heated debates about veiling and the interpretation of the Qur'an passages in question, and with respect to hadith literature, are prevalent within Muslim communities. The central question of these disputes is about a standardisation of the various manners of veiling for women. The concerns of global women's movements and Islamic feminists, who 
have declared a jihad against patriarchal control, ${ }^{1}$ are likewise inextricably linked to these issues. According to these women, the time of the Prophet was marked by a much higher degree of equality, that is, that the patriarchal interpretive authority came about only after the death of the Prophet Muhammad. Due to this, the interests and demands of this male authority were elevated into the position of status quo by a selective interpretation of the Qur'an passages in question. Because of these factors, it is imperative to take the sociocultural context of the 7th century, including its specific circumstances and challenges, into account when looking at the following passages. It has to be noted that veiling was a common fact of life in pre-Islamic times as well.

The Bundesarbeitsgericht (Federal Labor Court) has recently sided with a Muslim teacher from Berlin who had challenged the Neutralitätsgesetz (law of neutrality) on the basis that its barring of the wearing of any kind of religious symbols - including her veil - by teachers in public schools was discriminatory and in violation of her religious liberty. The plaintiff herself emphasises, however, that the conflict about the ambivalence of this symbol has in no way been settled by this ruling. On the contrary, the debate about it and the issue of religious liberty will, according to her, become only even more heated. ${ }^{2}$ The Egyptian reformer Qasim Amin dedicated an entire chapter of his 1899 book The Liberation of Women ${ }^{3}$ to the "Veiling of Women", where he generally agrees with the practice.

However, I demand that it has to be in accordance with the commandments of the Islamic shari'a. Veiling in accordance with the shari'a, however, is fundamentally different from what people today deem as transgressions against its religious articles in regard to veiling, thus both overstepping its boundaries, as well as acting to the detriment of the community itself. ${ }^{4}$

1 See Barlas 2004; Wadud 1999. The present paper has been translated from German by Florian Ksugas. The verbal quotes from German sources are repeated in the footnotes for clarity.

2 Finger 2020, 1.

3 Amin 1992, 64-5.

4 "Doch verlange ich, daß sie in Übereinstimmung mit den Geboten der islamischen Schari'a zu sein hat. Die Verschleierung aber im Sinn der Schari'a differiert ganz erheblich von dem, was die Leute heutzutage unter der Verschleierung in der Vorsicht und in der Befolgung der religiösen Satzungen schuldig machen und so die Grenzen der Schari'a überschreiten wie auch die wahren Interessen der Volksgemeinschaft schädigen" (Amin 1992, 64). 
On the issue of religious veiling he writes:

Were there any passages within the Islamic shari'a that demanded veiling in a way as is custom among some Muslim communities today, I would consider it my duty to forego any argument about it. In such a case, I would not write a single line that would dare contradict these passages, even if the practice of veiling where overtly harmful, for the divine commandments require absolute submission without objection. ${ }^{5}$

What, then, does the Qur'an actually have to say about veiling and covering up? The topic is mentioned in two surahs in the form of three specific terms: khimar and jilbab, both in the plural tense, as well as hijab.

Specifically, the surahs in question are surah 24 ("the light") and surah 33 ("the confederates"), both of which were revealed at Medina at around 626-7 (in-between the Battle of the Trench 627 and the Umrah). All three passages are contextually related to specific events at the time, which led to a call for the veiling of women, as well as their proper behaviour. Veils, as was already mentioned, were worn by women in pre-Islamic times as well, however the same is true for men. Examples of male veiling are sparse and mostly limited to preIslamic poetry, much of which was ideologically reinterpreted in later, Islamic, times. According to Knieps, it can be shown that, in preIslamic marriage, women enjoyed a higher degree of opportunity and protection by their tribes. ${ }^{6}$ Aisha is quoted as saying that women were, at a time, not required to veil themselves and that the practice is a novelty. ${ }^{7}$ It is before this background that the Qur'an's call for veiling starts to make sense.

There is no specific mention of a face veil in the Qur'an (burqu' and qina'). This, together with the Qur'an commentaries, has led to the position that the terms used in the Qur'an do not demand the veiling of the face and hands. However, the hair, neck, and ears are indeed to be covered.

5 "Gäbe es in der islamischen Schari'a Textstellen, die Verschleierung nach der bei einem Teil der Muslime heutzutage üblichen Art und Weise verlangten, dann hielte ich es für meine Pflicht, jede Diskussion darüber zu vermeiden. In diesem Falle schriebe ich auch nicht eine Zeile, die sich zu diesen Textstellen in Widerspruch setzte, selbst wenn diese Verschleierung offensichtlich auch noch so schädlich wäre, weil ja die göttlichen Befehle einen unbedingten Gehorsam verlangen, und zwar ohne Diskussion und Disput" (Amin 1992, 66-7).

6 Knieps 1993, 213.

7 Knieps 1993, 209. 


\section{Surah 24, 30-31}

This verse has to do with virtue and posits rules for the proper behaviour of both men and women. In other words, it is intended as a general code of conduct. ${ }^{9}$

Tell the believing men to lower their eyes and guard their private parts. That is purer for them. Surely God is Aware of whatsoever they do.

And tell the believing women to lower their eyes and to guard their private parts, and not to display their adornment except that which is visible thereof. And let them draw their kerchiefs [khumur, sg. khimar ${ }^{10}$ over their breasts, and not display their adornment except to their husbands, or their fathers, or their husband's fathers, or their sons, or their husband's sons, or their brothers, or their brother's sons, or their sister's sons, or their women, or those whom their right hands possess, or male attendants free of desire, or children who are innocent of the private areas of women. Nor let them stamp their feet such that the ornaments they conceal become known. And repent unto God all together, $\mathrm{O}$ believers, that happily you may prosper.

Grammatically, the verbs are expressed in the jussive mood, i.e. as an exhortation: "shall". "Private parts" is expressed by the plural tense of the Arabic word farj, namely furuj, translating into "the folds on one's body". Specifically, the term describes the armpits, the area between the thighs and buttocks, and - in the case of women - the cleavage. ${ }^{11}$ The instruction to "lower their eyes" is generally interpreted as a call to avoid gazing at the other sex so as to prevent the instigation of passion. Most scholars thus interpret the verse as a demand for female modesty to prevent the arousal of men. ${ }^{12}$

The term khimar has been interpreted in several ways:

Paret: "they shall draw their shawl over the slit of their garment running down from the front of the neck". ${ }^{13}$

8 See at-Tabari 1988, 10: 116-25.

9 The Qur'an passages follow the translation by Nasr et al. 2015.

10 Nasr et al. 2015, 875: "A khimār can mean a cloth that covers the head or neck; a scarf; a flowing garment; a garment without stitching; or a man's turban".

11 Ghadban 2013, 8.

12 See Hawting 2015, 1.

13 "Sie sollen ihren Schal sich über den (vom Halsausschnitt nach vorne heruntergehenden) Schlitz (des Kleides) ziehen” (Paret 1979, 246). 
Asad: "let them draw their head-coverings over their bosoms". ${ }^{14}$

Zaidan: "that they draw their headdresses over their cleavage". ${ }^{15}$ Knieps: "they shall place their veil cloth over their breast". ${ }^{16}$

Bobzin: "and that they draw their shawl over their cleavage". ${ }^{17}$

According to most scholars, this verse of surah 24 was revealed in connection to the so-called "Event of Ifk" during the campaign of 626-7. While the army had set up camp, Aisha, the Prophet's wife, left shortly before departure. On her way back she realised that she had lost her necklace and turned back once again. In the meantime, the caravan had already moved on, assuming that Aisha was sitting in her howdah. In the hope that she would be picked up soon, Aisha remained at the campsite. There, a member of the rearguard found her and gave her a lift on his camel back to the main army, which they reached at dawn while it had set up camp again. Soon, rumours about Aisha's supposed infidelity started spreading. When she asserted her innocence, the verses were revealed to the Prophet, proving Aisha's innocence, and speaking of a "tremendous calumny" against her $(24,16)$ :

Truly those who brought forth the lie were a group among you [...]. Why, when you heard it, did not the believing men and women think well of their own, and say, "This is a manifest lie?". Why did they not bring forth four witnesses thereto? For when they brought not the witnesses, it is they who were then liars in the Eyes of God. [...] And why, when you heard it, did you not say "It is not for us to speak of this! Glory be to Thee! This is a tremendous calumny!". God exhorts you, lest you ever return to the like of it, if you are believers. $(24,11-20)$

This revelation, which proved Aisha's innocence, is embedded into several other verses within the same surah, dealing with the issue of adultery and the defamation of innocent women:

Truly those who accuse chaste and heedless believing women are cursed in this world and the Hereafter, and theirs shall be a great punishment [...]. Vile women are for vile men, and vile men are for vile women, and good women are for good men, and good men are for good women. They are innocent of what they say. $(24,23)$

14 Asad 1980, 676-7.

15 "Dass sie ihre Kopfbedeckungen bis über ihre Kleidungsausschnitte ziehen" (Zaidan 2009, 590).

16 "Sie sollen ihre Schleiertücher über ihre Brust legen” (Knieps 1993, 204-5).

17 "Und dass sie sich ihren Schal um den Ausschnitt schlagen" (Bobzin 2010, 307). 
This is, in other words, a direct reference to the Event of Ifk.

Before the mentioning of a headscarf, yet another misdemeanour is addressed. Specifically, the entering of another person's house without permission.

O you who believe! Enter not houses other than your own, until you inquire and greet the dwellers thereof. That is better for you, that haply you may remember. But if you find not anyone therein, then enter them not until permission is granted you. And if it is said to you "Turn back", then turn back. That is purer for you, and God knows what you do. $(24,27-8)$

This verse has two explicit demands. On the one hand, that the $k h$ imar shall be drawn over the bosom, on the other hand that a women's adornments shall be only visible to the persons stated in the following lines. What kind of clothing should one picture when hearing the term khimar? A comparison with old-Arabic women's clothing can serve as a point of reference. It consisted

of a long and wide shirt-like dress with a long slit running from the front of the neck down to the waistline. In other words, had this opening not been specifically covered, there would have been the possibility of the woman's chest area becoming visible during certain movements or within certain postures. ${ }^{18}$

Furthermore, the woman's khimar should be pictured

as an unstitched wrap-around garment or a large wrap-around piece of cloth, which women could drape and position in a large variety of ways, including drawing it in front of their face in order to cover it. $^{19}$

The term khimar was used to refer to the male turban as well. Before this backdrop, the above-mentioned verse has to be understood as a call for women to draw their drapery (khumur) over the slit of their garments, thus negating the possibility of arousing glimpses at their décolleté.

18 "Aus einem langen und weiten hemdartigen Kleid, bei dem vom Halsausschnitt aus ein offener Schlitz in Richtung Taille nach unten reichte - ein Schlitz also, der, wäre er nicht zusätzlich bedeckt worden, bei bestimmten Bewegungen oder Körperhaltungen den Brustbereich der Frau hätte sichtbar werden lassen" (Wielandt 2009, 1-2).

19 "Als ein ungenähtes Schalgewand oder auch als ein großes Umschlagtuch ..., das die Frau in sehr vielfältiger Art drapieren und auch vor das Gesicht ziehen konnte, so daß es verhüllt war" (Knieps 1993, 106; see also 102-9). 
The question then becomes whether the plural tense of khimar, i.e. khumur, specifically refers to a means to cover one's head or simply to the drapery intended to cover the neck and breast area. In accordance with Islamic tradition, the term khimar has come to describe the headscarf with which women are to cover their head, as well as their hair. According to the Qur'an commentator Ibn Kathir, the term $k h$ imar describes "something to cover the head with". ${ }^{20}$ He goes on to say that "the khimar was also drawn over the neck and the breast so that they were no longer visible in any way". ${ }^{21}$ According to Kaddor, it was likely to have been "loosely placed over the head so that the hair was only partially covered, instead of the highly accurate way which we are familiar with today".22 The wearing of the khimar was not linked to social status, meaning it could be worn by all women.

However, opponents of the headscarf argue that both verses fail to explicitly mention the head, nor do the utilised terms make it clear which body parts are to be covered specifically. Instead, women were simply meant to cover the slit of their garments, and therefore their décolleté, by means of this piece old-Arabic women's clothing. Wielandt correctly notes that the covering of the cleavage could have been easily achieved by means other than the khimar, whether by a shawl or a high-necked gown.

Regardless of these circumstances, conservative religious scholars staunchly maintain that this passage commands the wearing of the khimar, or a modern variant of it, such as, for instance, the headscarf. ${ }^{23}$

Many parts of the commentaries dealing with this verse revolve around the meaning of the Arabic word zîna, translated here as "adornment". The primary challenge is the distinction between an adornment that may only be revealed to close relatives while being concealed from others, and one that may be publicly displayed. Adornment, in this context, includes the body parts that it is worn on. In early Islamic times, scholars differed in their opinion about whether the hair was to be considered a kind of adornment that had to be concealed from external persons. Later, the opinion that a woman's

20 Ibn Kathir 1981, 3: 114, quoted in Kaddor 2010, 135 ("etwas, mit dem man den Kopf verhüllen kann").

21 Ibn Kathir 1981, 2: 600, quoted in Kaddor 2010, 135 ("der khimar werde zudem um den Hals und über die Brust geworfen, so dass man davon nichts mehr sehen kann").

22 Kaddor 2010, 135 ("locker über den Kopf geworfen worden sein, so dass er das Haar nur zum Teil bedeckte und nicht so akkurat wie wir es heute kennen").

23 Wielandt s.d., 2 ("Dennoch folgern traditionsgebundene Religionsgelehrte aus dieser Stelle bis heute einhellig, dass an ihr das Tragen dieses chimar selbst oder einer modernen Variante von ihm wie z.B. des Kopftuchs geboten ist"). 
hair was part of her adornments, and therefore had to be concealed from male strangers, prevailed. The question of whether to cover the face is similarly debated in this context since, as demonstrated by old-Arabic poetry, a variety of face coverings were already in use. The Qur'an makes no mention of face coverings. Scholars are hotly debating the issue; however, the majority has opined against the wearing of a face veil as a religious obligation..$^{24}$

In relation to the question of the covering of women, it serves to take the following Qur'an verse into account as well. Here, the wives of the Prophet are prompted to not spend time on the streets but rather to remain at home..$^{25}$

Abide in your homes and flaunt not your charms as they did flaunt them in the prior Age of Ignorance. Perform the prayer, give the alms, and obey God only desires to remove defilement from you, $\mathrm{O}$ People of the House, and to purify you completely. $(33,33)$

Surah 24, 60 is of further interest. Here, the following concession is made:

As for elderly women who no longer anticipate marriage, there is no blame upon them to doff their garments (thiyab) without displaying any ornament.

According to Ghadban, this verse demonstrates the intention to control female sexuality "as to not jeopardise the legal parenthood of the father ${ }^{\prime \prime}{ }^{26}$ since people in pre-Islamic times practiced not only polygamy but also polygyny. Kaddor states

that women who were viewed as sexually irrelevant to men required no special protection from harassment by means of veiling. In this light, Qur'an 24,60 supports the hypothesis that the asbab an-nuzul, i.e. the events leading to the revelation of the dress code, were ultimately intended for the mitigation of potential conflict. ${ }^{27}$

24 See Wielandt s.d., 3; Duderija 2011, 107-8.

25 See Kaddor 2010, 145.

26 "Um die legale Vaterschaft nicht zu gefährden" (Ghadban 2013, 9).

27 "Dass Frauen, die im Hinblick auf Sexualkontakte uninteressant für die Männer sind, keines besonderen Schutzes vor Belästigungen durch eine entsprechende Verschleierung bedürfen. Damit stützt Koran 24:60 die These, dass die asbab an-nuzul, also die Anlässe für die Offenbarung der Kleidungsvorschriften im Grunde auf die Abwendung von Schaden abzielen" (Kaddor 2010, 147-8). 
O you who believe! Enter not the dwellings of the Prophet for a meal without waiting for its time to come unless leave be granted you. But if you are invited, enter; and when you have eaten, disperse [...]. And when you ask anything of [his wives], ask them from behind a veil [hijab]. That is purer for your hearts and their hearts.

Hijab means "barrier, covering, concealment" from other people's gazes. Following these connotations, it then received its meaning as a "curtain, veil". In this passage, hijab refers to a curtain, not a headdress. It was custom at Iranian and Byzantine courts to hide the women of the ruler from the gazes of visitors behind a curtain. Wielandt postulates that "this Qur'an verse could reflect an incorporation of this court etiquette into Islamic customs". ${ }^{29}$ Later on, scholars extended this specific rule for the wives of the Prophet to women in general, something that was justified by a call for gender segregation,

one of those early instruments of enforcement, apart from the covering of the head and - in an urban context - the face in front of strangers, also included the confinement of the woman into secluded quarters and her subsequent quasi-barring from the public space..$^{30}$

The isolation of the woman was also tied to a higher social standing. It is also the subject of debate why 33, 53 refers only to the wives of the Prophet while 33, 59 then goes on to include all Muslim women.

According to Islamic tradition, this verse was revealed in the wake of the events surrounding the Prophet's marriage to Zaynab bint Jahsh. ${ }^{31}$ Zaynab, a cousin of Muhammad, was the wife of Muhammad's adoptive son Zayd. One day, when the Prophet came to Zayd's house and asked for him, only Zaynab - who was unveiled - was at home. Zayd, knowing that the Prophet admired her, divorced his wife. According to tradition, the marriage ceremony took place in 627 at Medina. The Prophet, in accordance with custom, invited people off the street into his house to share a meal. Some of these guests overstayed their welcome, even though the Prophet had left several times before returning to see whether the guests had departed in the meantime,

28 See at-Tabari 1988, 12: 33-41.

29 "Dieser Koranvers eine Übernahme einer derartigen Hofetikette in den islamischen Rahmen reflektieren könnte" (Wielandt s.d., 4).

30 "Zu deren Instrumenten in früheren Zeiten außer der Verschleierung des Kopfes und im städtischen Bereich auch des Gesichts der Frau gegenüber fremden Männern noch die Beschränkung der Frau auf ein Frauengemach innerhalb des Hauses und ihr weitgehende Ausschluss aus dem öffentlichen Raum gehörten" (Wielandt s.d., 4).

31 See Kaddor 2010, 144-5; Knieps 1993, 184-90. 
which they only did at an extremely late hour. Umar supposedly recommended the Prophet to veil his women in general, reasoning that believers and non-believers alike were entering his home (this implicates that the women were not veiled). This may hold a kernel of factual concern. However, many traditions dealing with the hijab decree speak of immoral approaches toward the wives of the Prophet yet contradict each other in several details. Therefore, it has to remain unclear which events ultimately acted as the catalyst for the passing of the hijab decree. The final lines refer solely to the wives of the Prophet, not the wives of Muslims in general. In this way, they were identifiable as married women as opposed to a slave or a concubine. Thus, the hijab became "an expression of a social contract and legal order within Islamic society, a foundation for an ideal of virtue for Muslim women, as well as men" ${ }^{32}$ Later on, contrary to the view displayed in the Qur'an, the hijab served as the foundation for the veil of the woman, leading to its contemporary use as the de facto term for the female headscarf..$^{33}$

The term hijab appears seven times in the Qur'an, usually bearing a somewhat metaphorical connotation, but always describing a boundary/divider, never as a piece of cloth to cover one's body with.

42, 51: It is not for any human being that God should speak unto him, save by revelation, or from behind a veil, or that He should send a messenger in order to reveal what He will by His Leave.

7, 44-6: The inhabitants of the Garden will call out to the inhabitants of the Fire: "We have found that which our Lord promised us to be true. Have you found that which your Lord promised to be true?". They will respond: "Yes" [...]. And there will be a veil between them.

41, 5: They say: "Our hearts are under coverings from that to which you call us, and in our ears there is deafness, and between us and you there is a veil".

19, 16-17: And remember Mary in the Book, when she withdrew from her family to an eastern place. And she veiled herself from them. Then We sent unto her Our Spirit [...].

38, 32: I have preferred the love of good things over the remembrance of my Lord, until [the sun] was taken behind the veil.

32 "Ausdruck einer Sozialverfassung und einer Rechtsordnung der islamischen Gesellschaft .... Die Grundlage für ein Tugendideal der muslimischen Frau und des muslimischen Mannes" (Knieps 1993, 173).

33 See Wielandt s.d., 3. 


\section{Surah $\mathbf{3 3}, \mathbf{5 9 ^ { 3 4 }}$}

O Prophet! Tell thy wives and thy daughters, and the women of the believers to draw their cloaks [jalabib, sg. jilbab] over themselves. Thus is it likelier that they will be known and not be disturbed.

The following events are named as the catalyst for the revelation of this verse.

The wives of the Prophet left their house in Medina at night in order to relieve themselves. There, they were harassed by foreign men of the Ansar (the helpers) who were averse to the Prophet and his message. When questioned, they claimed that they had mistaken the women for slaves. Subsequently, the verse about the veiling was revealed. In other words, the wives of the Prophet should "draw their jilbab over their head and in front of their face". ${ }^{35}$ Islamists took this passage as a basis for their demand that women had to cover their face when outside the house.

The jilbab is a type of wrap-around garment, which, as a cloaklike mantle, offered a large variety of ways to cover oneself. At other times, the jilbab is equated with the khimar. Only free women were allowed to wear it outside the house, slaves were barred from doing so. As such, the jilbab was a means of establishing and displaying social status, namely the position of a free, honourable woman as opposed to a slave. This display of class distinction between free, honourable women and slaves had been ubiquitous throughout history in the oriental region. ${ }^{36}$ It is also an element in old-Arabic poetry. It is not, however, present in the Qur'an, originating instead during later times. As with the khimar, it is also a subject of debate whether the term jilbab refers to a headdress or simply a covering for the neck and breast area. It should be noted that the term occurs in the plural tense as well. Therefore, this verse contains no concrete instructions with regard to the covering of the hair or the face of the woman, either.

Kaddor points out that in old-Arabic times, the jilbab was worn over the khimar. Ultimately, the difference between the khimar and jilbab may have been miniscule at best. "This also means that the face remained generally uncovered by both the khimar and the jilbab. In this light, the call of Qur'an 33, 59 to 'draw over themselves' the jilbab makes sense". ${ }^{37}$

34 See at-Tabari 1988, 12: 45-7.

35 "Ihren dschilbab über den Kopf vor das Gesicht ziehen" (Wielandt s.d., 5).

36 See Kaddor 2010, 137.

37 "Das bedeutet auch, dass das Gesicht beim khimār und auch beim jilbāb prinzipiell frei blieb, sodass die Aufforderung in Koran XXXIII, 59, den jilbāb herunterzulassen, Sinn ergibt" (Kaddor 2010, 136). 


\section{Conclusion}

Summarising, it can be stated that Qur'an commentators are of wildly varying opinions as to how women should cover themselves. ${ }^{38}$ Tradition agrees in that the wives of Muhammad and the wives of the believers in general should not leave the house without a veil as described in the Jahiliyyah. However, none of the presented Qur'an passages explicitly mentions the covering of the head. Due to hadith verdicts, they were nonetheless interpreted in such a way by the later Islamic tradition. ${ }^{39}$ Stipulations regarding the "private area" ('aurah) of women, i.e. the body parts that are in need of covering, are derived from the hadith as well.

It was typical for jurists to discuss the question of dress, for both men and women, in terms of what must be covered in order to perform the canonical prayer, which was usually taken as equivalent to what had to be covered in the presence of those not listed in this verse. ${ }^{40}$

Jurists distinguished between three types of 'aurah. That of men, female slaves, and free women. Among Qur'an commentators and legal scholars, the idea of the female "private area" has shifted through the centuries to a point where it is believed "that every part of a woman, excluding her face and hands, belongs to her 'private area' and therefore needs to be covered". ${ }^{41}$ Some early viewpoints did not consider the veiling of the hair necessary either, arguing that there is no explicit mention of it in the Qur'an. "Other jurists considered a free woman's entire body to be 'aurah". ${ }^{42}$ According to these schools of law, only the area from the belly to the knees is considered part of the 'private area' in men and female slaves. This also has to do with the fact that women in general "are reduced to their sexuality". ${ }^{43}$ The entire Islamic legal tradition has furthermore asserted that the duty to cover herself only applies to sexually mature women "whose bodily features might cause arousal in men". ${ }^{44}$ This particularly extends to the allure of the female hair. However, no passage in the Qur'an as-

38 See Knieps 1993, 203.

39 See Wielandt s.d., 5.

40 Nasr et al. 2015, 875.

41 "Dass bei der Frau alles außer Gesicht und Hände, Blöße' und daher zu bedecken ist" (Wielandt s.d., 6).

42 Nasr et al. 2015, 875.

43 "Auf ihre Sexualität reduziert wird" (Ghadban 2013, 11).

44 "Von deren Körpermerkmalen Reize auf die Männer ausgehen können" (Wielandt s.d., 7). 
sociates the covering of the female hair with moral behaviour. This was a later development. The great theologist and legal scholar AlGhazali (d. 1111) has contributed markedly to the picture of the woman as the great seductress and her subsequent styling as a purely sexualised object. According to him,

due to the psychological inferiority of men, they are in need of protection from the power of women. Due to his physical superiority, this protection takes on the shape that the woman has to burden the "necessary" restrictions - namely, to cover her nakedness. ${ }^{45}$

According to Al-Ghazali, women should better not leave the house at all.

The Qur'an, therefore, did not establish a new dress code, incorporating old-Arabic traditions and customs regarding dress code and veiling instead. Quite a few of these traditional guidelines were, however, abolished or reinterpreted as defined by God. ${ }^{46}$ When the different schools of law established the guidelines for covering, they naturally included the opinions of the scholars, as well as the morals and customs of their culture and society. This illustrates how deeply ingrained into contemporary influences the concept of the veiling of women had been. It can be ascertained "that the majority of existing arguments don't date to the time of the Prophet but to the world of the (male) scholars of the Abbasid period and later on". ${ }^{47}$ Particularly the verses of surah 24 are sought out by commentators as an argument for the veiling of women since they also happen to include a code of conduct. All these elaborations exist before the backdrop of a demand for a change in the social behaviour of men towards women. On the other hand, stands the call for a shift in the social attitude of woman towards men. In this, the veil is an expression of a social structure and reflects the ideal of a free, married woman within the society in question. ${ }^{48}$ The distinction between the sacred and mundane veil exists in Islamic times as well. The passages in the surahs 24 and 33 refer to the mundane veil. An example for sacral clothing would be the gown for the pilgrimage to the Kaaba. ${ }^{49}$

45 "Aufgrund der psychischen Unterlegenheit des Mannes, muss er vor der Macht der Frauen geschützt werden. Aufgrund seiner physischen Überlegenheit sieht der Schutz so aus, dass die Frau die, erforderlichen' Einschränkungen zu (er-)tragen hat - nämlich ihre Blöße zu verbergen” (Kaddor 2010, 142).

46 See Kaddor 2010, 134.

47 "Dass ein Großteil der Argumentationen nicht auf die Zeit des Propheten zurückgeht, sondern auf die (männliche) Gelehrtenwelt der Abbasiden-Zeit und später" (Kaddor 2010, 141).

48 See Knieps 1993, 173-4.

49 See Knieps 1993, 373. 
Ultimately, the veil can only ever make sense before the background of the social realities of the Arab world of its day. "There is in no way a clear dictate for veiling but an indirect compulsion resulting from the social circumstances at the time", ${ }^{50}$ which required the veil as a protective social mechanism. However, because the environment that humans exist in is subject to constant change, the circumstances for the verses relating to veiling in the Qur'an must inevitably change as well. ${ }^{51}$

The female veil is a "veil of habit", a fabric difficult to grasp which was and still is subject to a constantly changing social reality, which in turn is an expression of the sociological and psychological state of a society. ${ }^{52}$

Nowadays, the varying hermeneutical approaches to the Qur'an show two conflicting approaches. On the one hand, those who consider the headscarf to be a mandatory and integral part of societal norms and who not only take the Qur'an into account, but also the hadith where the Prophet's Sunna is expressed, which claims authority as a guideline for proper Muslim behaviour. On the other hand, those who dismiss the command to wear a headscarf as irrelevant in contemporary times, arguing that God and the Prophet

addressed a highly specific social framework shaped by the cultural realities of the time. As such, they had to choose the means to reach their goals in a way that would be intelligible and implementable [...] to the people of old Arabia during Muhammad's lifetime. ${ }^{53}$

50 "Von einem direkten Zwang zur Verhüllung kann also keine Rede sein, sehr wohl aber von einem indirekten Zwang, der aus den damaligen sozialen Gegebenheiten resultierte" (Kaddor 2010, 148).

51 See Kaddor 2010, 149.

52 “Der Schleier der Frau ist ein 'Schleier des Verhaltens', ein nur sehr schwer fassendes Gewebe, das stetigen gesellschaftlichen Einflüssen und Änderungen unterworfen war und immer noch ist, der auch Ausdruck einer sozialen und psychischen Verfassung einer Gesellschaft ist" (Knieps 1993, 182).

53 "In eine ganz bestimmte zeit- und kulturbedingte sozialgeschichtliche Situation hineingesprochen haben, in der Wahl der konkreten Mittel, die sie zur Erreichung dieses Zieles vorsahen, so äußern mussten, wie es den damaligen Verstehens- und Verhaltensmöglichkeiten [...] der alten Araber im Umfeld Muhammads, entsprach" (Wielandt s.d., 10). See Duderija 2011, 169-87. 


\section{Bibliography}

Amin, Q. (1992). Die Befreiung der Frau. Aus dem Arabischen übertragen von $O$. Rescher. Bearbeitet und mit einer Einführung versehen von Smail Balic. Würzburg, Altenberge.

Asad, M. (1980). The Message of The Quran. Gibraltar. http://www. muhammad-asad.com/Message-of-Quran.pdf.

Barlas, A. (2004). Believing Women in Islam. Unreading Patriarchal Interpretations oft he Qur'an. Austin.

Bobzin, H. (2010). Der Koran. München.

Duderija, A. (2011). Constructing a Religiously Ideal 'Believer' and 'Woman' in Islam. Neo-Traditional and Progressive Muslims' Methods of Interpretation. New York.

Finger, E. (2020). "Der falsche Stoff”. Die Zeit, 3, September, nr. 37.

Ghadban, R. (2013). Das Kopftuch in Koran und Sunna. Mit einer Einleitung von Johannes Kandel, 2003. https://library.fes.de/pdf-files/akademie/online/50370.pdf.

Hawting, G. (2015). Sure 24 Vers 31. Der zentrale Vers zum Kopftuch. https:// www. deutschlandfunk.de/sure-24-vers-31-der-zentrale-verszum-kopftuch.2395.de.html?dram:article_id=331983.

Ibn Kathìr, 'I. (1981). Mukhtașar tafsir Ibn Kathïr. 3 vols., 7th ed. Beirut.

Kaddor, L. (2010). "Warum das islamische Kopftuch obsolet geworden ist. Eine theologische Untersuchung anhand einschlägiger Quellen". Schneiders, T.G. (Hrsg.), Islamverherrlichung. Wenn die Kritik zum Tabu wird. Wiesbaden, 131-55.

Khoury, A.T. (1987). Der Koran. Übersetzung von A.T. Khoury. Unter Mitwirkung von M. Salim, A. Mit einem Geleitwort von Inamullah Khan. Gütersloh.

Knieps, C. (1993). Geschichte der Verschleierung der Frau im Islam. Würzburg.

Nasr, S.H. et al. (eds) (2015). The Study Quran. A New Translation with Notes and Commentary. San Francisco.

Paret, R. (1979). Der Koran. Stuttgart; Berlin; Köln; Mainz.

at-Tabari, A.J.M. (1988). Dschāmi' al-bayān 'an ta'wīl āy al-Qurāàn. 15 Bde. Beirut. Wadud, A. (1999). Qur'an and Woman. Rereading the Sacred Text from a Woman's Perspective. 2nd ed. Oxford.

Wielandt, R. (2009). Die Vorschrift des Kopftuchtragens für die muslimische Frau. Grundlagen und aktueller innerislamischer Diskussionsstand. http:// ankommenapp.de/SharedDocs/Anlagen/DIK/DE/Downloads/ Sonstiges/Wielandt_Kopftuch.pdf?__blob=publicationFile (2020-09-07).

Zaidan, A.M.A. (2009). At-tafsiir. Der Quraan-Text, seine Transkription und Übersetzung. Wien.

Zirker, H. (2003). Der Koran. Darmstadt. 



\title{
The Bonnet and the Beret in Medieval and German Renaissance Art
}

Margit Stadtlober

Universität Graz, Österreich

\begin{abstract}
This paper presents an art-historic contribution, examining the bonnet and the beret as characteristic forms of female and male headdresses and their manifold variations and oriental origins. Both types of head coverings are shaped by sociocultural attitudes and evolved in form. Embedded within the wider context of clothing they also, in turn, influence social norms and attitude. Examining their history and genesis also reveals and raises gender-specific perspectives and questions. The depiction and representation of the bonnet and beret during two defining periods in the visual arts, incorporating role-play and creativity, present a considerable knowledge transfer through media. First instances of gender-specific dress codes can be traced back to the Bible and therefore Paul's rules for head covering for women in 1 Cor 11,2-16 is intensively debated. The following chapter will trace and illustrate the history of female and male head coverings on the example of various works of art. The strict rules outlined in 1 Corinthian 11 prescribing appropriate head coverings in ceremonial settings, which had a significant and lasting impact, have in time been transformed through the creative freedom afforded by the mundanity of fashion.
\end{abstract}

Keywords Beret. Bonnet. Female Head Covering. Hennin. Veil.

Summary 1 Introduction. - 2 From Veil to Bonnet. - 3 The Beret and Dürer's Caps.

\section{Introduction}

In March 2020, the University of Graz hosted the interdisciplinary Festival Alpe-Adria dell'Archeologia Pubblica senza Confini on the topic of "Headscarves and veils from the ancient Near East to modern Islam". This paper presents 
an art-historic contribution, examining the bonnet ${ }^{1}$ and the beret as characteristic forms of female and male headdresses and their manifold variations and oriental origins. Both types of head coverings are shaped by sociocultural attitudes and evolved in form. Embedded within the wider context of clothing they also, in turn, influence social norms and attitudes.

The correlation between people and clothing becomes particularly evident in relation to headwear. What is significant here is that the headwear reflects back on the physical as well as the mental stance of the wearer. ${ }^{2}$

Examining their history and genesis also reveals and raises genderspecific perspectives and questions. The depiction and representation of the bonnet and beret during two defining periods in the visual arts, incorporating role-play and creativity, present a considerable knowledge transfer through media that deserves closer investigation.

Images or visual-artistic mediation have a strong impact on how the depicted content is received. The hermeneutics of images ${ }^{3}$ reconstructs the information flow of this century-old medium. Methods of iconography and iconology further examine the content of images and their genesis. Additionally, text/image studies provide a comparison between systems of textual and pictorial communication. Art is an important medium that carries information across temporal boundaries, it is characterised by specific communicative mechanisms and operates within specific sociological contexts. It is important to note that communication through words is distinctly different from communication through images. Susanne K. Langer concludes in her theory of art Feeling and Form that texts are discursive, whereas images are presentative. ${ }^{4}$ It is precisely this presentative component that allows images to effectively communicate across language barriers. This also exposes worldviews and gender perceptions. The figures depicted in images, along with the clothes they wear, often reflect dominant notions of 'femininity' and 'masculinity', social roles and expectations, and culture-specific stereotypes at a given point in time.

1 Bonnet is a generic term in English for female headdress (particularly during the Middle Ages and Renaissance) and is used here in its broadest meaning, similar to and as a translation of the German term Haube, which also denotes various forms of head coverings.

2 Loschek 1993, 108. Unless otherwise stated, all translations are by the Author.

3 Bätschmann 2003, 199-228.

4 "Formulation, representation, abstraction: these are the characteristic functions of symbols. As such they have been studied, however, mainly in connection with discursive symbols" (Langer 1973, 376-7). 
First instances of gender-specific dress codes can be traced back to the Bible. Initially, there is no marked difference between male and female items of clothing as attributed to Adam and Eve. According to the Bible, God made them loincloths from fur (Gen 3,21), without any gender-relevant distinctions. Only 1 Corinthian 11 refers to differentiations between male and female clothing with regard to Christian ceremonies: ${ }^{5}$

\section{Head Coverings}

(2) Now I commend you because you remember me in everything and maintain the traditions even as I delivered them to you. (3) But I want you to understand that the head of every man is Christ, the head of a wife is her husband, and the head of Christ is God. (4) Every man who prays or prophesies with his head covered dishonours his head, (5) but every wife who prays or prophesies with her head uncovered dishonours her head, since it is the same as if her head were shaven. (6) For if a wife will not cover her head, then she should cut her hair short. But since it is disgraceful for a wife to cut off her hair or shave her head, let her cover her head. (7) For a man ought not to cover his head, since he is the image and glory of God, but woman is the glory of man. (8) For man was not made from woman, but woman from man. (9) Neither was man created for woman, but woman for man. (10) That is why a wife ought to have a symbol of authority on her head, because of the angels. (11) Nevertheless, in the Lord woman is not independent of man nor man of woman; (12) for as woman was made from man, so man is now born of woman. And all things are from God. (13) Judge for yourselves: is it proper for a wife to pray to God with her head uncovered? (14) Does not nature itself teach you that if a man wears long hair it is a disgrace for him, (15) but if a woman has long hair, it is her glory? For her hair is given to her for a covering. (16) If anyone is inclined to be contentious, we have no such practice, nor do the churches of God. (1 Cor 11,2-16)

This explanation by Paul in 1 Cor 11,2-16 is intensively debated in Bible Studies and extensively explored within the field of theology. ${ }^{6}$ It is not for art history to comment on this; but it can reflect on it. The text establishes that women, same as men, can perform ceremonial acts in the Christian community. However, the requirement for women to cover their heads as opposed to men, who must keep their heads uncovered, explicitly marks them in their gendered difference. The

5 Dettinger 2017, 152-6; Gielen 1999; 2001; 2002; Gielen, Merklein 2005, 25-72. Jantsch 2015a; 2015b; Marshall 2017, 203-13; Schottroff 2013, 280-4; Zamfir 2013, 342-4. 6 Jantsch 2015a. 
rule is justified with the argument that women are subordinate to men as evidenced by the woman having been created after man (Gen 2,21 f.). She is denied direct connection to God through Christ and is not recognised as an image of God. This represents a multi-layered gendered subjugation of women. The subsequent mention that God intended men and women for each other does not retract from the above. Further, head coverings and women's hair are both defined as a form of covering, the lack or removal of which is a mark of shame. This also creates distinctly gendered rules for men and women with regard to hair. Men are allowed to cut their hair and must not cover it up. Women are not allowed to cut their hair as they must be and remain covered. The question whether this instruction for women to cover their head intends for women to wear their hair as a covering lies beyond the scope of this paper. ${ }^{7}$

Another relevant Bible text that is more women-friendly is Proverbs 31,10-31, setting out the characteristics of a good housewife.

The Woman Who Fears The Lord

(10) An excellent wife who can find? She is far more precious than jewels. (11) The heart of her husband trusts in her, and he will have no lack of gain. (12) She does him good, and not harm, all the days of her life. (13) She seeks wool and flax, and works with willing hands. (14) She is like the ships of the merchant; she brings her food from afar. (15) She rises while it is yet night and provides food for her household and portions for her maidens. (16) She considers a field and buys it; with the fruit of her hands she plants a vineyard. (17) She dresses herself with strength and makes her arms strong. (18) She perceives that her merchandise is profitable. Her lamp does not go out at night. (19) She puts her hands to the distaff, and her hands hold the spindle. (20) She opens her hand to the poor and reaches out her hands to the needy. (21) She is not afraid of snow for her household, for all her household are clothed in scarlet. (22) She makes bed coverings for herself; her clothing is fine linen and purple. (23) Her husband is known in the gates when he sits among the elders of the land. (24) She makes linen garments and sells them; she delivers sashes to the merchant. (25) Strength and dignity are her clothing, and she laughs at the time to come. (26) She opens her mouth with wisdom, and the teaching of kindness is on her tongue. (27) She looks well to the ways of her household and does not eat the bread of idleness. (28) Her children rise up and call her blessed; her husband also, and he praises her: (29) "Many women have done excellently, but you surpass them all". (30) Charm is deceitful, and beauty is vain, 
but a woman who fears the Lord is to be praised. (31) Give her of the fruit of her hands, and let her works praise her in the gates. (Proverbs 31,10-31)

Irmtraud Fischer's inaugural speech at the University of Graz offers an invaluable and objective account exploring this Bible passage following different methodologies and yielding extensive insight for understanding the text in how it addresses women. ${ }^{8}$ She concludes that the exegetical tradition postulated by Cardinal Michael Faulhaber in 1912, defining the text as in praise of the wife - a "classic M-voice"9 with lasting impact - has undergone transformation through the progress of time and societal change. Irmtraud Fischer presents several arguments supporting the view that the above Bible acrostic is spoken by a theologian of high social standing addressing her children. One such argument that the notion of the model wife, a genius of productivity working around the clock without pause, goes far beyond household chores is supported by the description of her clothing as being precious. ${ }^{10}$ It is dyed in expensive colours, such as purple (in blue and red) and possibly even carmine, which are produced from animals. ${ }^{11}$ These so-called luxury fabrics not only demonstrate female financial power, but an intertextual reading of the Bible also reveals parallels with ceremonial fabrics reserved for sacred places and artefacts, and those worn by priests. The domain of the praised wife is not limited to the domestic sphere, it "rather demands that the wife has a right to what she has produced and that she is recognised in the public sphere, in the gates, for her own work". ${ }^{12}$ The text does not mention any head coverings to be worn by women, as such it does not establish a gender-specific dress code. However, female attractiveness is minified in verse 30: "Charm is deceitful, and beauty is vain". This could suggest that the rule for women to cover their head, in whatever form, in ceremonial settings is intended as an instruction to hide their female attractiveness. An intertextual approach points to further passages in the Bible where women are advised to practice modesty in their appearance: "Do not let your adorning be external - the braiding of hair and the putting on of gold jewelry, or the clothing you wear" (1 Peter 3,3).

This original decree on female head coverings found in the Bible also forms the background and context within which to situate the bonnet. It consistently accompanies or is accompanied by the veil and

8 Fischer 2005.

9 Fischer 2005, 238.

10 Brockmöller 2004.

11 Fischer 2005, 248.

12 Fischer 2005, 252. 


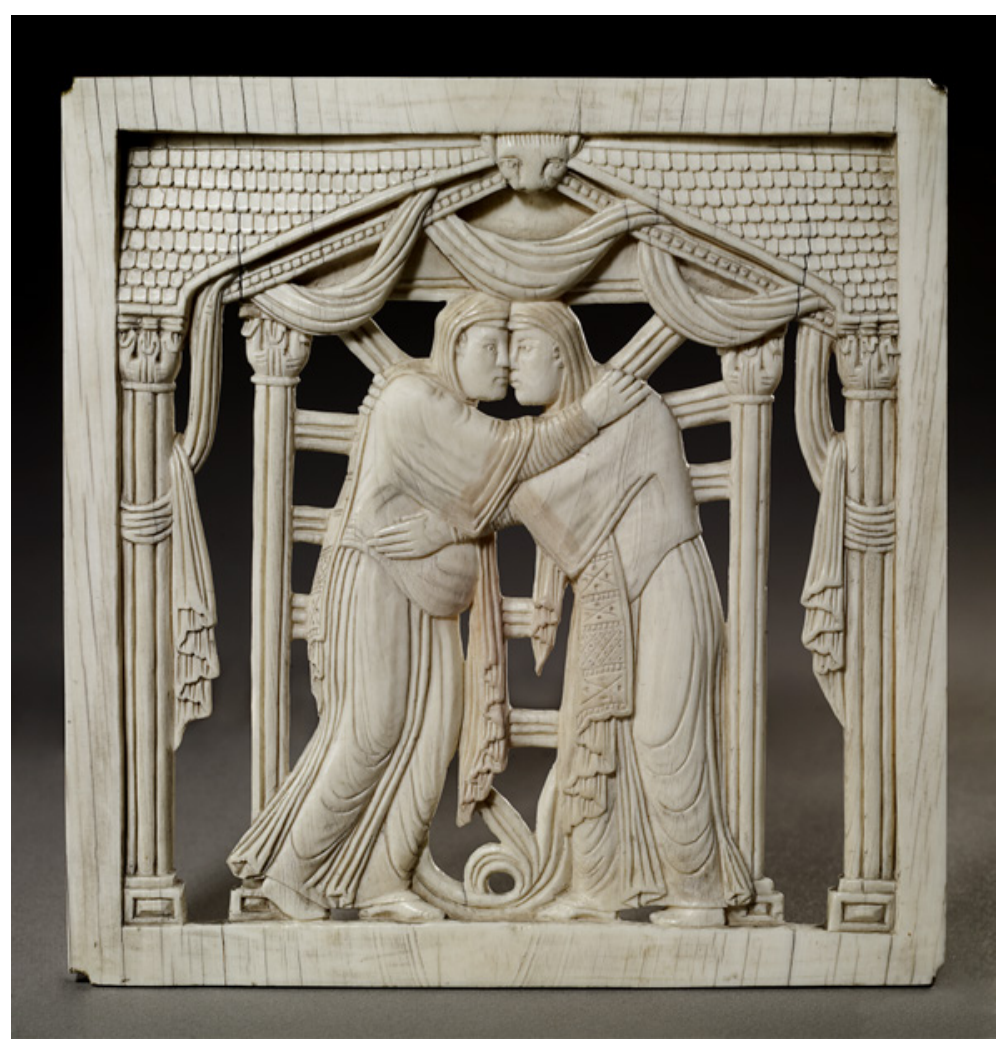

Figure 1 Heimsuchung Mariens von den so genannten Magdeburger Elfenbeintafeln, Inv.-Nr. 17/418, photo nr. D70051. @ Bayerisches Nationalmuseum München (photo Bastian Krack)

the two are permanently combined in the Middle Ages. ${ }^{13}$ The bonnet thus undergoes creative evolution and transformation. It becomes imbued with meaning and acts as a social marker for women, as demonstrated for example in the well-known German proverb: Unter die Haube kommen, literally "to bring under the bonnet", meaning to be married off. ${ }^{14}$ The following chapter will trace and illustrate the history of female head coverings on the example of various works of art. 
Etymologically, the English term 'bonnet' is derived from the Old French bonet denoting material from which hats are made and the Latin abonnis referring to headdress. The German term Haube is derived from the Middle High German hûbe, ${ }^{15}$ meaning 'round head covering'. Bonnets and their different shapes and designs have a long history. In the following, this section traces the evolution of the veil, which is closely interlinked with the evolution of the bonnet, in the transalpine context from the Middle Ages to the beginning of the Modern Era when the bonnet's popularity as a fashion accessory reached its peak. The 11th century saw a linen kerchief that was loosely draped over the head and fastened under the chin with an agraffe. In the 12th century, this evolved into a stiffer variation, and in the 13th century it took on a fixed shape. This formed the basis from which various distinct regional styles emerged in the High and Late Middle Ages, for example the wimple, the Hulle, and the Rise. ${ }^{16}$

The Romanesque ivory relief depicting a visitation, 962-73 [fig. 1], donated by Otto the Great to the Cathedral of Magdeburg, shows the two expecting mothers Mary and Elizabeth wearing traditional Frankish costumes consisting of a tunic, a short coat and a flat veil, which is already layered into folds (so-called Vächern in German) to lend it a more voluminous appearance.

This layering of the veil can take on significant dimensions with regard to sin and luxury, as illustrated by the clothing that characterises Superbia in Herrad of Landsberg's Hortus Deliciarum, 1175 [fig. 2]. ${ }^{17}$ The extravagant shape of the headdress is similar to that of a turban and is shown to consist of a very large brown cloth. The luxurious use of fabric is also reflected in the long flaring sleeves, which also served to puff up the wearer's appearance and were more decorative than useful in function. The dress is of a regal crimson purple, the cloak of an equally precious blue purple, both plain with no pattern. The pointed crakows are no less a fashion fad of the time.

Lady World is draped in expensive attire with similar flaring sleeves as she introduces poverty to a monk as illustrated in a book painting found in the Benedictine Abbey of Engelberg [fig. 3].

She wears a cap-like head covering on top of her veil, an addition that also appears in the Schöngrabern relief of Luxuria, further adorned with striking decorative elements [fig.4]. 
Margit Stadtlober

The Bonnet and the Beret in Medieval and German Renaissance Art

Figure 2

Superbia, as in Herrad of Landsberg (1125-1195), Hortus Deliciarum.

Ca. 1180. Written at the Hohenburg Abbey.

Facsimile by Christian Moritz Engelhardt ca. 1818. Strasbourg, Bibliothèque nationale et universitaire, inv. no. ark:/12148/ bpt6k9400936h. https://commons. wikimedia.org/wiki/Category:Hortus Deliciarum?

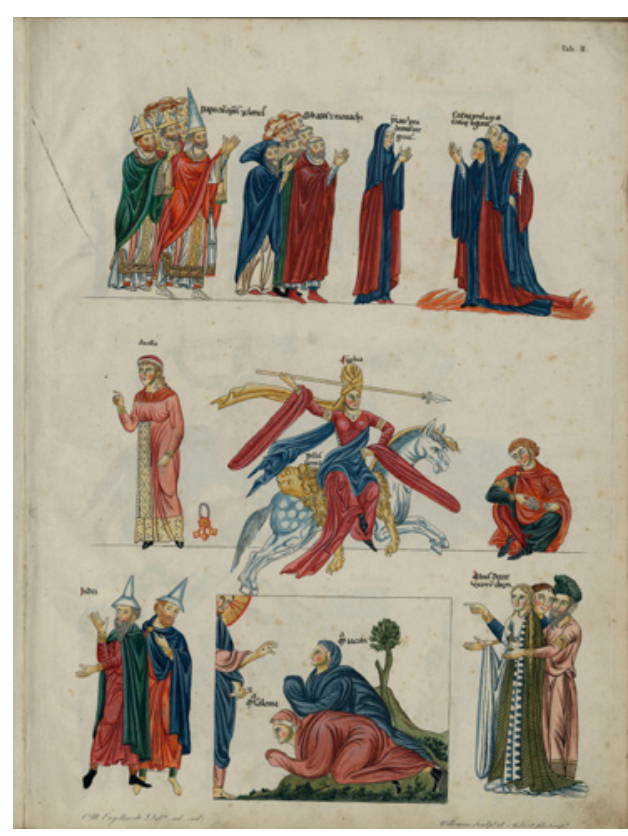

Figure 3

Frau Welt stell teinem Mönch die Armut vor. 1197-98. Book painting. Engelberg (Switzerland), Stiftsbibliothek. (๑) Thie 2004, 108, fig. 191

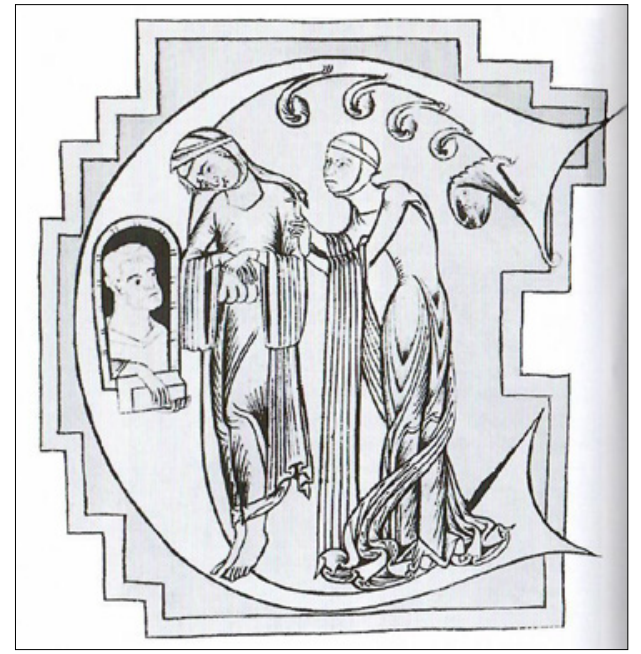


Margit Stadtlober

The Bonnet and the Beret in Medieval and German Renaissance Art
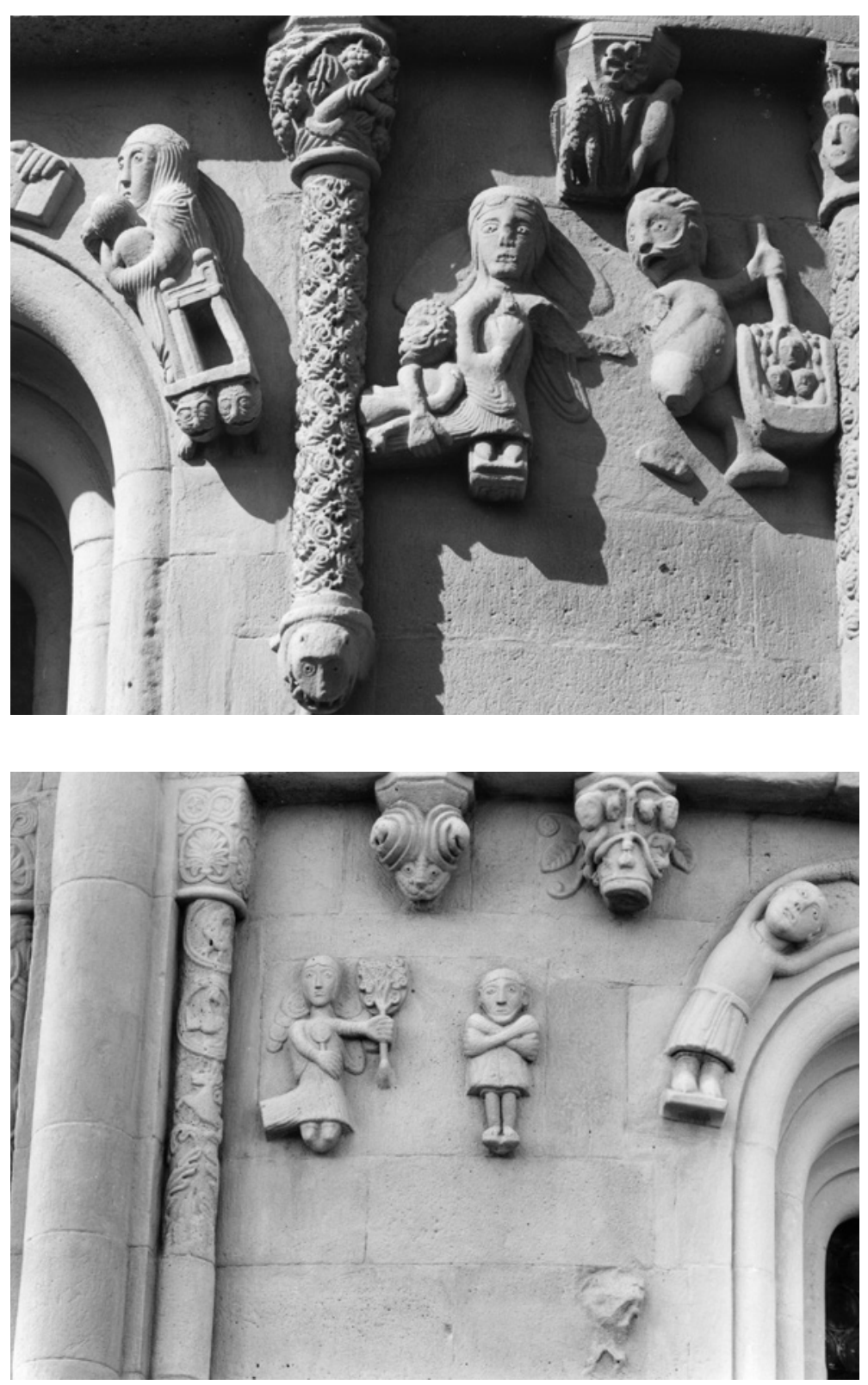

Figure 4 Luxuria. 1225-30. Schöngrabern, parish church, apsidal relief. (c) Bundesdenkmalamt (photo Bettina Neubauer 1997)

Figure 5 Lady World. 1225-30. Schöngrabern, parish church, apsidal relief. (c) Bundesdenkmalamt (photo Bettina Neubauer 1997) 
The twelve-part sculptural work on the Eastern facade of the apse at the parish church in Schöngrabern (Lower Austria), 1225-30, is a dramatic depiction of the eschatological path from Original Sin to Last Judgement. The high reliefs are likely the work of four or five sculptors, as evidenced by slight stylistic differences, and have not yet been conclusively classified in terms of style or fully analysed in their iconography. This so-called stone Bible from Schöngrabern contains within it a wealth of information about the early 13th century, which was first heretically interpreted and later understood from a Christian perspective. ${ }^{18}$ Both the sequence of individual scenes and the individual elements create an unusual iconography, which Martina Pippal examined in constant reference to patristic literature..$^{19}$ Seen from bottom/south to top/north, the reliefs depict scenes from the OT and NT, including illustrations of battles against wild animals (psychomachia) as part of the eschatological narrative. The story concludes with Luxuria being condemned to hell in the upper tier of the south bay. She is shown as wearing an elaborate fascinator around her veil, ornaments around her chest and wide flaring sleeves, with a little demon sitting on her train. In the upper tier of the north bay, a woman similar in appearance and a man are depicted in the foreground of the scene. The female figure is particularly interesting and presents a yet unsolved mystery as to who she is and what she symbolises. She wears a long dress with a train and in her right hand she holds an object consisting of a round disk attached to a handle [fig. 5].

With her left hand she holds a small flowering tree. The male figure to the left of her crosses his arms tightly in front of his body. This posture could signify that the woman is to be interpreted with a negative connotation. A possible positive interpretation, however, is that the woman represents summer while the man represents winter, or they symbolise Scientia. The clothing of the second female figure in the Schöngrabern relief is simpler than that of Luxuria, she does not wear any intricate ornaments or wide flaring sleeves. In comparison, the rose window at Notre-Dame in Paris, the Cathedral windows in Auxerre and Lyon, as well as the illustration in Paris, Bibliothèque de l'Arsenal, MS 6329, fol. 167v show Luxuria as an elegant woman looking into a mirror. In this context, the Schöngrabern relief could be interpreted in the sense that the flowers in the woman's left hand are violets and rose petals that Luxuria throws at Virtue in an act of distraction, as described in Prudentius' Psychomachia (vv. 326-327). ${ }^{20}$ Only Sobrietas succeeds in defeating her with the standard of the cross. Fol. 106r of cod. 1898 at the Austrian National Library in Vienna from 
the second half of the 13th century shows an initial adorned with figures as an illustration for Psalm 68 in which God is depicted as a young Christ, along with David and an elegantly dressed woman with a mirror, who Andreas Fingernagel was not able to identify. ${ }^{21}$ Based on the fact that the female figure is depicted with red cheeks, looking at the mirror held above and facing away from God, it is likely that this is a representation of Luxuria fleeing from God (Psalm 68,2-3). Further, looking at the difference in clothing as worn by Luxuria condemned to hell, the woman depicted in less extravagant clothes at Schöngrabern is likely Lady World, as already encountered in the book paintings from Engelberg. It is also not flowers that she holds in her left hand but a flowering twig, the Medieval symbol for the granting of fiefs. ${ }^{22}$ Thus, Lady World wants to grant the man in the Schöngrabern relief the world as a fiefdom by giving him the little flowering tree. He, in turn, rejects her offer, God-fearing, with his arms crossed around his body.

Soon, female head coverings became fashion objects that experimented with the possibilities of form and shape. One such example is the kruseler, a veil with ruffled ends. The origin of this variation, the loose kerchief, is thus still clearly recognisable. The kruseler is also depicted as a head covering in images of saints and the Madonna, as exemplified in the limestone effigy of Saint Elizabeth, 138090 [fig. 6] ${ }^{23}$ and the Madonna effigy carved from poplar wood found at Sonntagberg, 1420 [fig. 7]. ${ }^{24}$

Different headdresses also incorporated hairstyles such as plaits and buns. Closed head coverings worn over combed back and tied hair became a symbolic marker for married women. Often, any hair that was still visible under or despite the cap was shaved off. Only unmarried women were allowed to wear their hair loose and the schapel was exclusively reserved for them.

In addition, women of nobility wore a Gebende covering the bottom half of their face. Etymologically, the term is derived from the Old High German bant (meaning 'ribbon'; or 'binding' in English). The Gebende is a white ribbon that is tightly wound around the top of the head, ears, and chin. It can be worn in combination with a schapel or a headband made of stiffened linen. During the later period of the Middle Ages, between 1385 and 1480, female head coverings took on extraordinary shapes and dimensions, such as the hennin or horned headdress, often up to $60 \mathrm{~cm}$ high. ${ }^{25}$ It is possible that

21 Fingernagel, Roland 1997, 60, fig. 79.

22 This valuable information was provided by the legal historian Gernot Kocher in conversation.

23 Brucher 2000, 368; Schweigert 2019, 641.

24 Brucher 2000, 90-1.

25 von Boehn 1925, 218-19. 


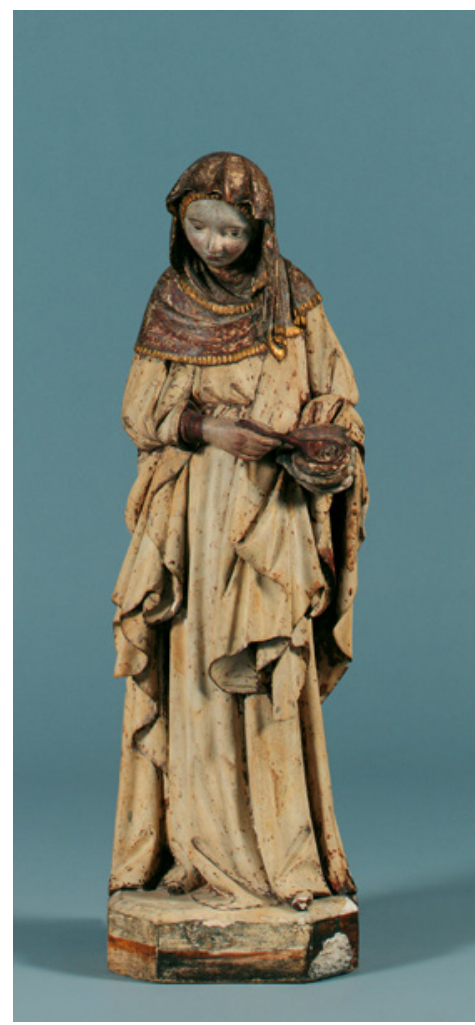

Figure 6 Saint Elizabeth of Thuringia. 1380-90. Fine limestone. Vienna, Österreichische Galerie Belvedere, inv. no. 4897. (c) Vienna, Österreichische Galerie Belvedere

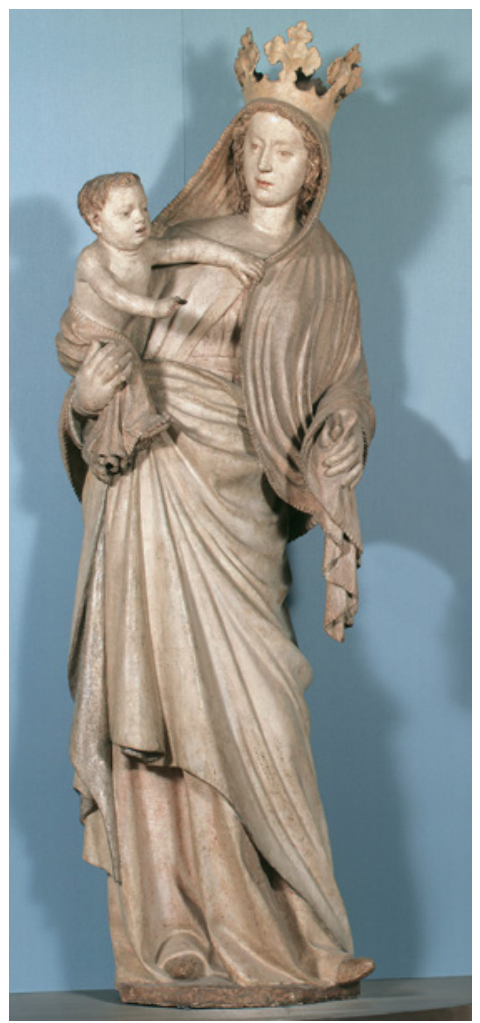

Figure 7 SonntagbergerMadonna. 1420. Poplar wood, Vienna, Österreichische Galerie Belvedere, inv. no. 4831. (c) Vienna, Österreichische Galerie Belvedere

this conical shape with a flowing veil attached at the tips, often long enough to reach the floor, was adopted from oriental styles as trade relationships increased. The tantour is a historic headdress made from silver or silver-plated copper worn by women in Lebanon and Syria. Its name translates as horn according to its cone-like shape ${ }^{26}$ or as soft chime. ${ }^{27} \mathrm{~A}$ thin veil consisting of large quantities of fabric attached at the top and cascading down to the hips was used to cover women's faces. What is interesting is that this horn-shaped headdress was initially referred to in the Bible (Job 16,15; Jeremiah 48,25; 
Psalms 112,$9 ; 132,17$ and 148,14$)^{28}$ as a status symbol worn by men, that was then adopted by their wives as a marital symbol, thus taking on significant symbolism. It was worn differently than the hennin, either attached to a cushion, or tilted forward from the forehead, or to the side. ${ }^{29}$ Thus, the hennin's origin can be traced back to the Orient, as is the case with the turban, which became popular with women and men in the Middle Ages. In Italy, the gugel took on a turban-like shape in the 14th century and became known under the French name chaperon. ${ }^{30}$ The first person to wear a hennin, in silver, is thought to be Isabeau of Bavaria, at her wedding to Charles VI of France. ${ }^{31}$ The hennin is a very elaborate headdress that had to be pinned to a hairnet worn underneath, often still visible on the forehead. It was positioned such that it was slightly tilted backwards for a more attractive look, ${ }^{32}$ as seen in a portrait of Mary of Burgundy by Niklas Reisers, c. 1500 [fig. 8].

The extravagance was immediately met with criticism. Jan Hus' De sacerdotum et Monachorum carnalium abominatione heavily criticised this escalation of fashion:

[Women] wanted to be horned in their own appearance by wearing a fantastical adornment to also publicly demonstrate their nature as animals; on their heads they arrange their veils with a certain art and much effort so that at least three horns, one above the forehead, the others on the crown, protrude from their heads. ${ }^{33}$

In the Renaissance, it was common for women to wear caps and for long periods, particularly in transalpine regions due to climate conditions and based on local traditions. They became an integral element of different regional traditional costumes, such as found in Nuremberg or Augsburg. Head coverings also functioned as markers of religious affiliation. Catholics wore the Augsburg Riegelhaube or Ringelhaube, Protestants wore the Bockelhaube. Veils gradually disappear towards the end of the Middle Ages in the transalpine context with only few variations that combine bonnets and veils remaining in fashion.

28 Ritter 1850, 189.

29 Sommer 1840, 76.

30 Loschek 1993, 112.

31 Loschek 1993, 114.

32 Sommer 1840, 76.

33 Cited according to Thiel 2004, 147 ("wollten durch eine wunderbare Anordnung selbst gehörnt sein in ihrer äußeren Erscheinung, damit sie gleichfalls öffentlich zeugten, daß sie dem Tiere zugehören; denn auf ihren Köpfen gestalten sie die Schleier mit einer gewissen Kunst und nicht ohne große Mühe so, daß mindestens drei Hörner, eines über der Stirn, die anderen auf dem Scheitel des Hauptes hervorragen"). 


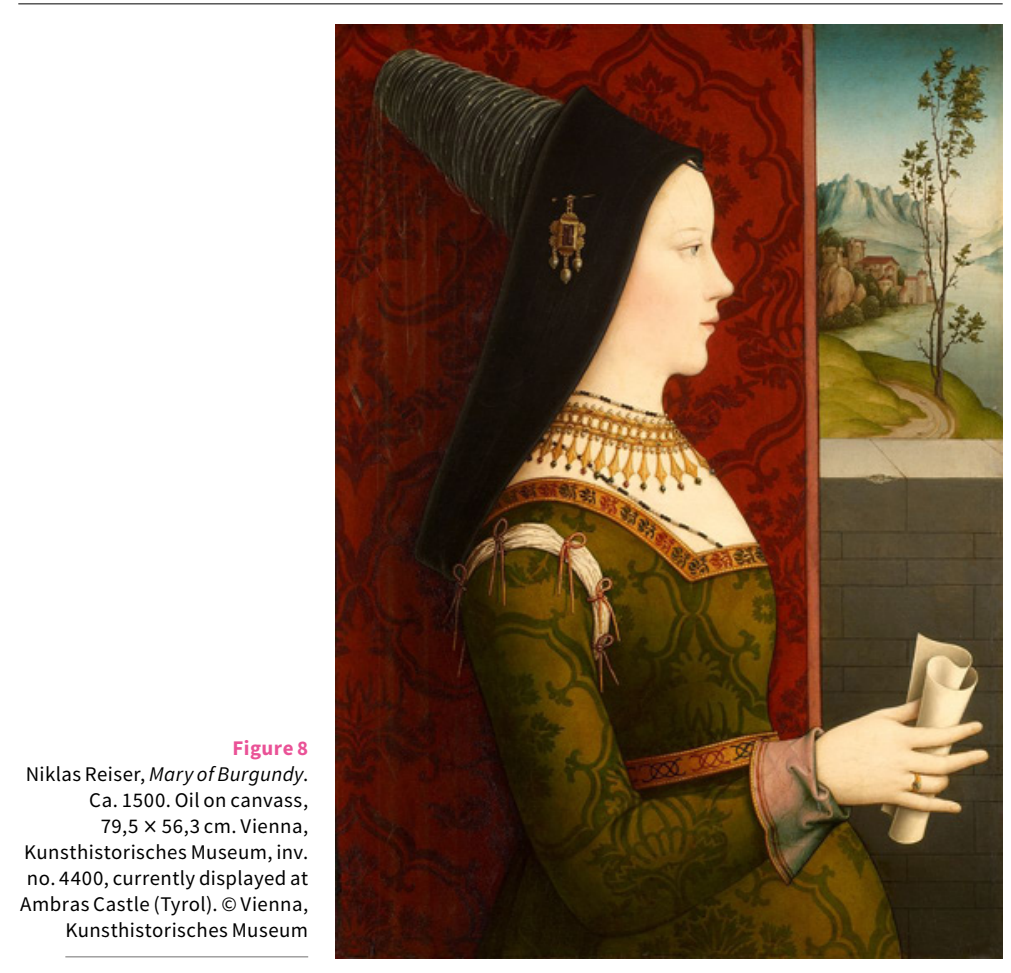

\section{The Beret and Dürer's Caps}

The beret was a head covering initially exclusively worn by men. Etymologically, the name traces back to the Medieval Latin terms barete, biret(e) or barretum, which in turn originate from the Latin birrus or birrum, meaning hooded cape. ${ }^{34}$ It presents an early version of head coverings, which were simply part of the outer garment and were pulled up over the head. ${ }^{35}$ The Gallic cucullus, a hood with a collar, formed the basis for the gugel, a variation of a hood with a collar that was fashionable in the Middle Ages. ${ }^{36}$ Another historically important head covering is the pileus, ${ }^{37}$ a cap of semi-spherical shape that was the mark of freed Roman slaves and thus constitutes an early symbol of social status in Roman antiquity. The Medieval beret has

34 Mackensen 2013, 63.

35 Jantsch 2015b, 107.

36 Loschek 1993, 110.

37 Loschek 1993, 109. 
a certain similarity with Fez-like caps in that it maintains its shape and can include a brim. It may be this consistency in shape that allowed the beret to become the first head covering to be worn in various styles, whether square on top of the head for official purposes or pushed to the side as in the landsknecht uniform, which required an undercap underneath. ${ }^{38}$ This male head covering can also take on additional meaning, considering the German proverb etwas auf seine Kappe nehmen, literally 'to take on one's cap', meaning taking on responsibility. ${ }^{39}$ In contrast to the bonnet, which assigned women societal and marital status, the beret symbolises responsibility, taking charge, thus representing masculine characteristics. The feminine bonnet hides, whereas the beret signals potential.

As illustrated by Anton Pilgram's sculpture, The Falconer, c. 1495 [fig. 9], the beret also had a practical function, as seen in this hunting costume.

In Lucas Cranach's painting, John Cuspinian and his wife Anna, née Putsch, 1502-03 [fig. 10] ${ }^{40}$ wear their festive costumes with beret and Kugelhaube respectively. The double portrait thus shows the two gender-specific head coverings next to each other. The woman and the man in the painting both crown their festive dress with a headdress. The beret of the scholar is of a bright, deep red. Anna's headdress is a light colour and embroidered with golden patterns matching the gold necklace and rings. Yet, there is a difference between man and woman and their head coverings on a symbolic level: while the woman's headdress and the white carnation in her right hand signify her marital status and symbolise the promise of her wedding vows, the man's head covering is also part of his professional attire as a physician and scholar.

Albrecht Dürer demonstrates variation and creativity in drawing and painting himself with long hair and wearing caps of different shapes and forms. His Self-Portrait at the Age of 13, 1484, ${ }^{41}$ already illustrates an example of these unusual headdresses. He wears a similar cap-like head covering with tassels in his Portrait of the Artist Holding a Thistle, $1493 .{ }^{42}$ Dürer is depicted as holding the eryngo plant, known to him as aster atticus, with both hands, the flower corresponding to the meaning of the inscription at the top edge of the painting: My sach die gat | als es oben schtat (loosely translated as "My affairs follow the course allotted to them on high").

38 Loschek 1993, 116.

39 Loschek 1993, 108.

40 Stadlober 2006, $180 \mathrm{ff}$.

41 Albrecht Dürer, Self-Portrait at the Age of 13, 1484, Vienna, Albertina, inv. no. 1484

42 Albrecht Dürer, Portrait of the Artist Holding a Thistle (Sternkraut, Aster Atticus), 1493, oil on canvass, originally parchment, $57 \times 45 \mathrm{~cm}$, Paris, Louvre, no. RF 2382. An inscription at the top edge of the painting reads: My sach die gat | als es oben schtat. 


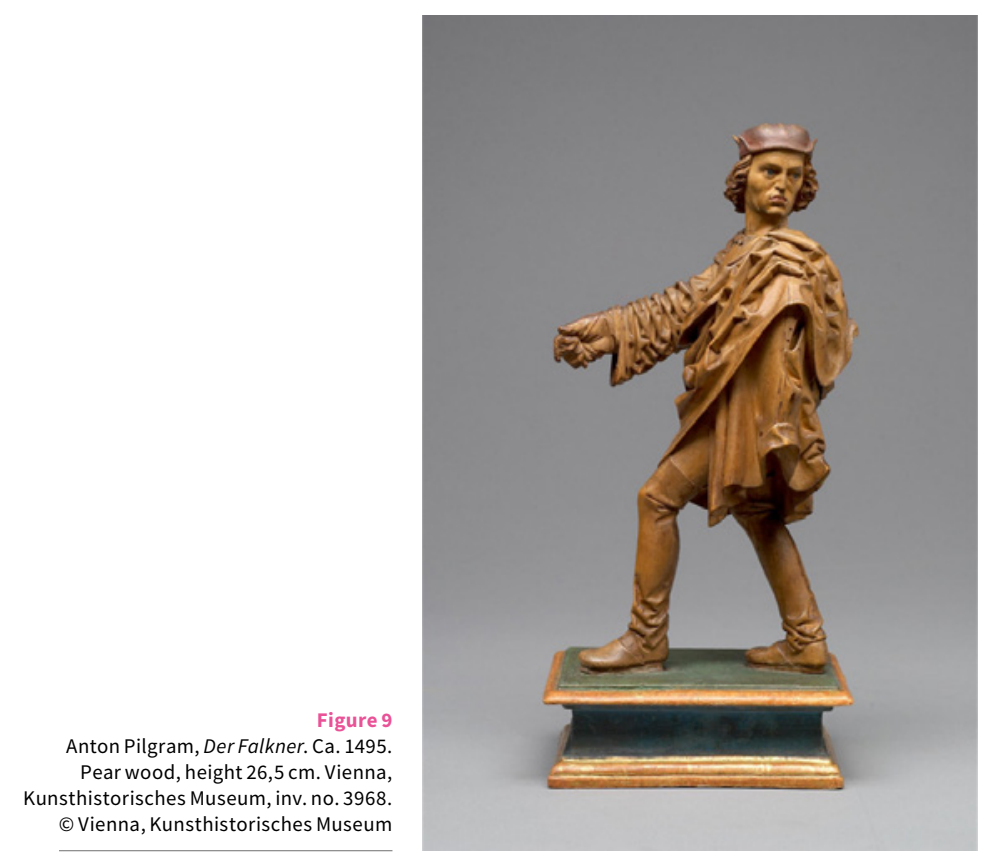

Dürer's self-portrait, 1498 [fig. 11], at the Prado museum in Madrid marks the height of his extravagant dress style. His attire perfectly matches and forms a harmonious whole, from the cap-like headdress complete with tassel to the elegant leather gloves in a black and white pattern with a graphic aesthetic. The clothes he painted himself in also corresponds to his remark: Ich pynn ein zentilam zw Fenedig worden (Here I am a gentleman, at home only a parasite). ${ }^{43}$ Dürer's long hair becomes progressively longer and curlier as he gets older. In this painting, he also sports a fine moustache and chin beard, which contravened fashionable taste at the time and were frowned upon. ${ }^{44}$ Dürer's flamboyant and unique look also transgresses the rules on hairstyles and head coverings laid out in the Bible, as described above, and increasingly resembles the traditional image of Christ with curly shoulder-length hair parted in the middle after Nazarene fashion and a short beard. A fictitious report printed in Venice in 1494 also purported as much. Thus, Dürer demonstrably did not adhere to the gender-specific rules as prescribed by the Bible, as 


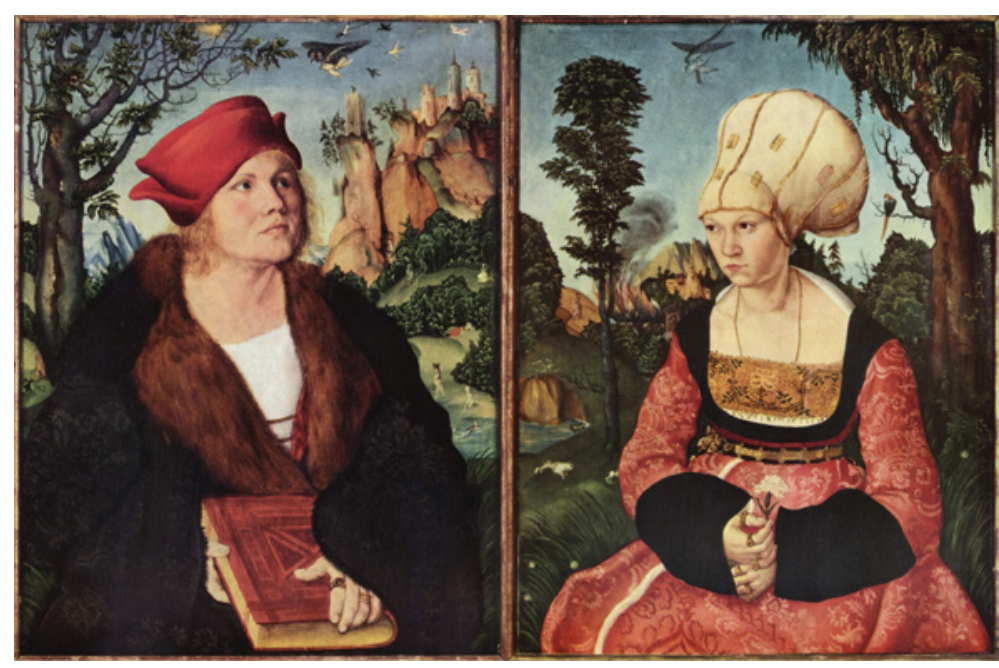

Figure 10 Lucas Cranach, The Wedding Portrait of Dr. Johannes Cuspinian and Anna Cuspinian-Putsch. 1502-03. Oil on wood. Winterthur, Collection Oskar Reinhart, inv. no. 1925.I. https://commons.wikimedia.org/ wiki/File:Lucas_Cranach_d.\%C3\%84._-_Johannes_und_Anna_Cuspinian_(Sammlung_Oskar_Reinhart).jpg

did many young men in the transalpine regions. Wilhelm Wätzold's comments on Dürer's Portrait of the Artist Holding a Thistle already saw him as clad in "a dandy costume of a squire, the many details of which almost appear feminine". ${ }^{45}$

The same era sees the beret transcend gender divisions, making it an early transgender accessory. Emperors, noblemen and peasants all wore it in a democratic sense, although it retained stylistic differences according to status. However, now women wore the beret too. Lucas Cranach's Venus [fig. 12] appears in her naked beauty, only wearing a dark red velvet beret, next to Cupid stealing honey. She wears the strikingly chic headdress, also worn by men in this form, to the side, attached to an ornate undercap (calotte) underneath.

The transformation of the beret from a once exclusively male headdress to an all-gender accessory was also documented by contemporaries such as Johann Geiler von Kaysersberg: "Now women behave like men and wear a beret with a cock's feather". ${ }^{46}$

45 Wätzold 1935, 34: "junkerlich stutzenhafter Tracht, deren zahlreiche Kleinformen fast etwas Weibliches an sich haben".

46 Cited according to Thiel 2004, 174: "Es gon jetzt Frauen wie die Man und hond Baretlin mit Hahnenfederlin uff". 


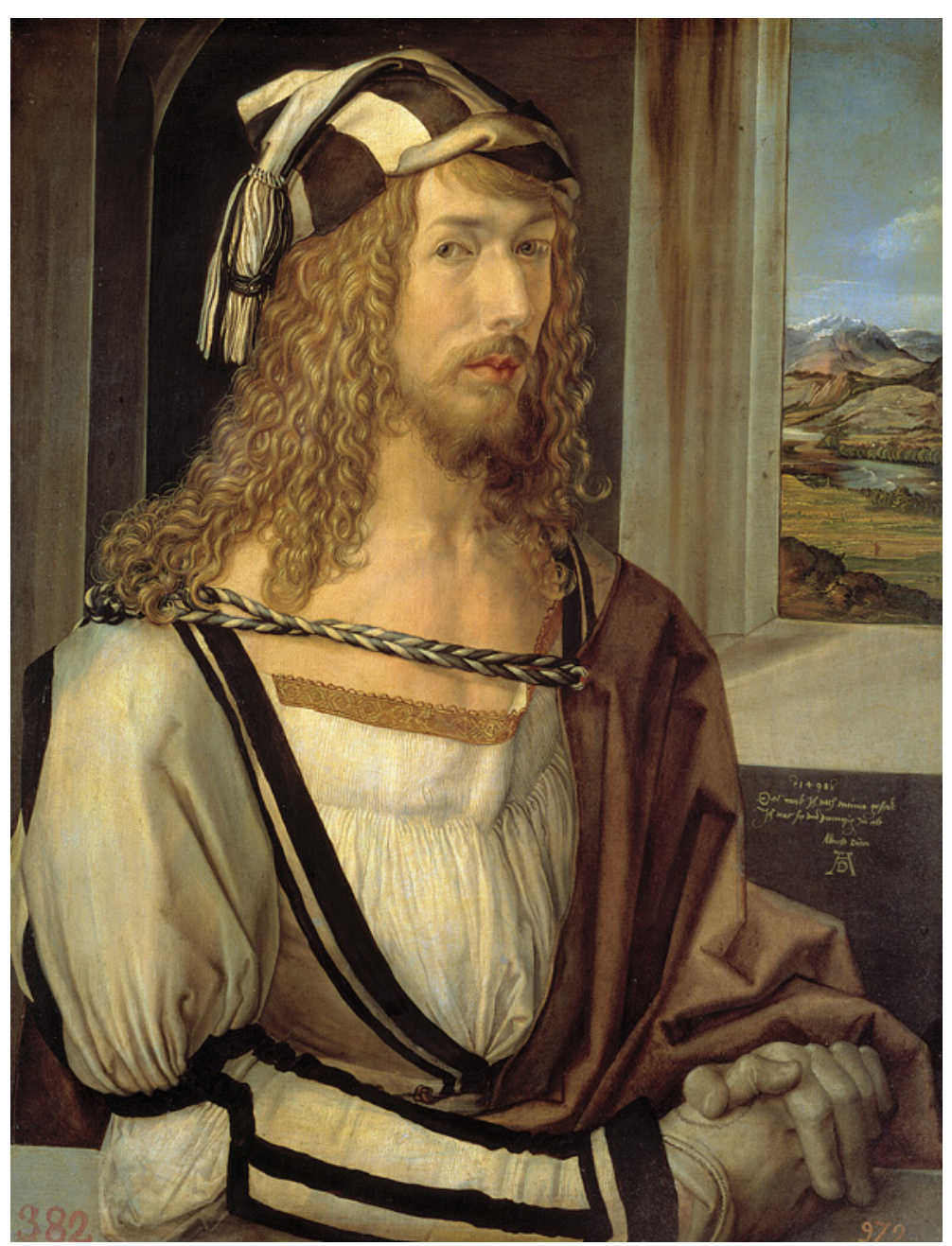

Figure 11 Albrecht Dürer, Self-Portrait. 1498. Oil on wood, 52 × 40 cm. Madrid, Prado, inv. no. P002179. (c) Madrid, Prado

This transgendered transformation of the beret also concludes the observations made here. The strict rules outlined in 1 Corinthian 11 prescribing appropriate head coverings in ceremonial settings, which had a significant and lasting impact, have now been transformed through the creative freedom afforded by the mundanity of fashion. In wearing the beret, women no longer hide themselves behind a veil. Instead, they wear the beret as an accessory and playfully subvert and transfer dominant characteristics previously only reserved for men. With the beret, women rid themselves of the sym- 


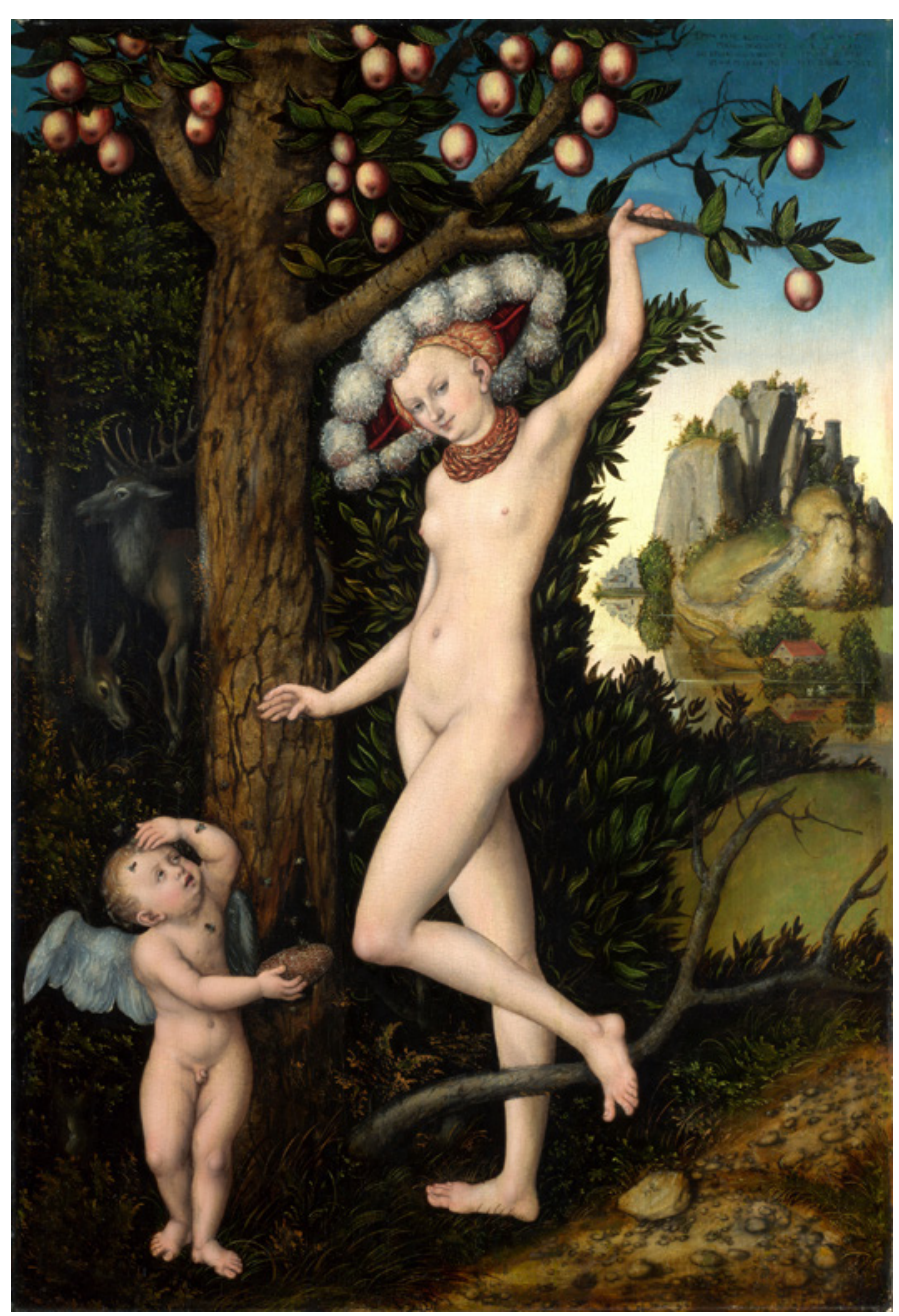

Figure 12 Lucas Cranach, Cupid Complaining to Venus. Ca. 1530. Oil on wood. $81,3 \times 54,6 \mathrm{~cm}$. London, National Gallery, inv. no. NG6344. https://de.wikipedia.org/wiki/Venus_mit_ Amor_als_Honigdieb_(London)

bolism attached to headdresses that defined them as belonging to or subordinate to men. The sumptuous elegance of the beret as in the example above underlines the overt eroticism, ${ }^{47}$ thus standing in stark contrast to the modesty of the veil towards the end of the Mid- 
dle Ages and prompting the accompanying inscription ${ }^{48}$ that clearly serves as moral admonishment.

\section{Bibliography}

Bätschmann, O. (2003). "Anleitung zur Interpretation. Kunstgeschichtliche Hermeneutik”. Belting, H. et al. (Hrsgg), Kunstgeschichte. Eine Einführung. 6. Aufl. Berlin, 199-228.

Brockmöller, K. (2004). Eine Frau der Stärke. Wer findet sie? Exegetische Analysen und intertextuelle Lektüren zu Spr 31, 10-31. Berlin.

Brost, H. (1984). Kunst und Mode. Eine Kulturgeschichte vom Altertum bis heute. Stuttgart; Berlin.

Brucher, G. (2000). Geschichte der bildenden Kunst in Österreich 2. Gotik. Munich; London; New York.

Carboni, S. (2007). Venezia e l'Islam 828-1797 = Catalogo della mostra. Venice.

Dettinger, D. (2017). Neues Leben in der alten Welt. Der Beitrag frühchristlicher Schriften des späten ersten Jahrhunderts zum Diskurs über familiäre Strukturen in der griechisch-römischen Welt. Leipzig.

Fillitz, H. (ed.) (1998). Geschichte der bildenden Kunst in Österreich 1. Früh- und Hochmittelalter. Munich; London; New York.

Fingernagel, A. (ed.) (2007). Romanik 2. Graz.

Fingernagel, A.; Roland, M. (1997). Mitteleuropäische Schulen I (ca. 1250-1350). 2 Bde. Vienna. Veröffentlichungen der Kommission für Schrift und Buchwesen des Mittelalters 1. Die illuminierten Handschriften und Inkunabeln der Österreichischen Nationalbibliothek 10. Denkschriften der Österreichischen Akademie der Wissenschaften, Phil.-hist. KI. 245.

Fischer, I. (2005). "Gotteslehrerin. Ein Streifzug durch Spr 31, 10-31 auf den Pfaden unterschiedlicher Methodik". Scoralick, R.; Ebner, M. (Hrsgg), Biblische Zeitschrift, N.F., 49, 237-53.

Galter, H.D. (2001). Kopftuch und Schleier. Kulturgeschichte eines orientalischen Phänomens. Graz.

Geppert, S. (2013). Mode unter dem Kreuz, Kleiderkommunikation im christlichen Kult. Salzburg.

Gielen, M. (1999). "Beten und Prophezeien mit unverhülltem Kopf? Die Kontroverse zwischen Paulus und der korinthischen Gemeinde um die Wahrung der Geschlechtrollensymbolik in 1Kor 11,2-16". ZNW, 90, 220-49.

Gielen, M. (2001). "Gehört es sich, daß eine Frau unverhüllt zu Gott betet? Der Streit um Kopfbedeckung oder Frisur in 1Kor 11, 2-16”. Eltrop, B.; Hecht, A. (Hrsgg), Frauengottesbilder. Stuttgart, 75-81.

Gielen, M. (2002). "Gehört es sich, daß eine Frau unverhüllt zu Gott betet? Der Streit um Kopfbedeckung oder Frisur in 1Kor 11, 2-16". Bibel und Kirche, 57(3), 134-8.

48 As Cupid was stealing honey from the hive a bee stung the thief on the finger. And so do we seek transitory and dangerous pleasures that are mixed with sadness and bring us pain (Als der Knabe Cupido [...] Honig stahl, stach die Biene dem Dieb in den Finger. So schadet auch uns die kurze, vergängliche Wollust, die wir begehren: Mit traurigem Schmerz ist sie vermischt). 
Gielen, M.; Merklein, H. (2005). Der erste Brief an die Korinther. 1Kor 11, 2-16, 24. Gütersloh.

Gillen, O. (ed.) (1979). Herrad von Landsberg, Hortus deliciarum. Neustadt.

Jantsch, T. (2015a). "Einführung in die Probleme von 1Kor 11,2-16 und die Geschichte seiner Auslegung". Jantsch, T. (Hrsg.), Frauen, Männer, Engel. Perspektiven zu 1Kor 11, 2-16. Neukirchen-Vluyn, 1-60.

Jantsch, T. (2015b). "Die Frau soll Kontrolle über ihrem Kopf ausüben. 1 Kor 11, 10". Jantsch, T. (Hrsg.), Frauen, Männer, Engel. Perspektiven zu 1Kor 11, 2-16. Neukirchen-Vluyn, 97-144.

Koch-Mertens, W. (2000). Der Mensch und seine Kleider. Teil 1, Die Kulturgeschichte der Mode bis 1900. Düsseldorf; Zurich.

Langer, S.K. (1973). Feeling and Form. A Theory of Art Developed from Philosophy in a New Key. 5th ed. London.

Loschek, I. (1993). Accessoires. Symbolik und Geschichte. Munich.

Mackensen, L. (2013). Ursprung der Wörter. Das etymologische Wörterbuch der deutschen Sprache. Aalen; Pößneck.

Marshall, J.E. (2017). Women Praying and Prophesying in Corinth. Gender and Inspired Speech in First Corinthians. Tübingen.

Pippal, M. (1991). Die Pfarrkirche von Schöngrabern. Eine ikonologische Untersuchung ihrer Apsisreliefs. Vienna.

Prudentius (1962). Works with an English Translation by H.J. Thomson. The Loeb Classical Library. London.

Ritter, C. (1850). Vergleichende Erdkunde. Die Erdkunde im Verhältniss zur Natur und zur Geschichte. Bd. 2, Sinai-Halbinsel, von Palästina und Syrien. Berlin.

Rupprich, H. (ed.) (1956). Dürers Schriftlicher Nachlass, Bd. 1. Berlin.

Schottroff, L. (2013). Der erste Brief an die Gemeinde in Korinth. Stuttgart.

Schweigert, H. (2019). "Architektur der Gotik in der Steiermark, Malerei und Bildhauerkunst der Gotik in der Steiermark". Pferschy, G. (Hrsg.), Die Steiermark im Spätmittelalter. Vienna; Cologne; Weimar, 641.

Sommer, J.G. (1840). Taschenbuch zur Verbreitung Geographischer Kenntnisse, Eine Übersicht des Neuesten und Wissenswürdigsten im Gebiete der gesamten Länder- und Völkerkunde, Bd. 18. Prague.

Stadlober, M. (2006). Der Wald in der Malerei und der Graphik des Donaustils. Vienna; Cologne; Weimar.

Thiel, E. (2004). Geschichte des Kostüms. Die europäische Mode von den Anfängen bis zur Gegenwart. Bd. 8. Ergänzte und aktualisierte Auflage unter Beratung von Dorothea Dieren und Gretel Wagner. Berlin.

von Boehn, M. (1925). Die Mode. Menschen und Moden im Mittelalter. Vom Untergang der alten Welt bis zur Renaissance. Munich.

Wätzold, W. (1935). Dürer und seine Zeit. Leipzig.

Zamfir, K. (2013). Men and Women in the Household of God. A Contextual Approach to Roles and Ministries in the Pastoral Epistles. Göttingen.

Zitzelsberger, P. (Hrsg.) (2010). Kleidung im Bild, Zur Ikonologie dargestellter Gewandung. Emsdetten; Berlin. 



\title{
On the Contemporary Debate About the Headscarf in Austria
}

Carla Amina Baghajati

IGGÖ (Islamische Glaubensgemeinschaft in Österreich), Österreich

\begin{abstract}
The aim of this paper is to trace the debates around the Muslim headscarf in Austria and the related political measures. Looking back over a period of 30 years, the changes in public opinion and in political attitudes concerning the Muslim headscarf are analysed in greater detail. The headscarf functioned as a projection screen for extremely diverse questions and attitudes and the resulting narratives are a barometer of public opinion within the majority society regarding issues like migration, women rights or Islam. At the same time, they show the need for self-assurance about personal identity in a multioptional society and the tension between secularism and the traditional Austrian cooperation model on religious matters. The paper touches on the question of equal opportunities for men and women and on the relationship between the inner-Muslim discourse and the external perspective.
\end{abstract}

Keywords Headscarf debate. Austria. Islamic headscarf. Burqa ban. Political Islam. Islamophobia.

Summary 1 Introduction. - 2 Austria's Long and Laid-back Relationship with the Headscarf. -3 Headscarf Decrees by the Ministry of Education. - 4 Protection Against Discrimination in the Workplace since 2004. - 5 First Topicalisations of Headscarf Bans in Austria. - 6 Dialogforum Islam. - 7 2015. The Breaking Point in Austria's Islam Policy? 8 Burqa Ban. - 9 Ban on Headscarves at a Kindergarten Age. - 10 Headscarf Ban in Primary Schools. - 11 Muslim Attempts to Participate in and Influence the Debate. - 12 Outlook.

\section{Introduction}

Whether the woman wearing it is conscious of it or not, the Muslim headscarf is an object that, in its visibility, lends itself to being symbolically charged. In this, a piece of cloth is turned into a potential transmitter of messages, often including ideological connotations. The wearer herself is confronted with the 
reality that her head covering is associated with a variety of meanings that she may not have intended at all.

What are these associations? When confronted with the term 'Islamic headscarf', some people may think of pictures of women wearing headscarves shown from behind, wrapped in dark, flowing garments, or photographs of burqa wearing women under the Taliban regime, perhaps also in the context of right-wing populism. These associations make it easy to take the mental step towards thinking of the 'oppression of women, coercion, and the patriarchy'. There are other representations as well, such as young, stylishly clothed women bearing a friendly smile on their faces. They are increasingly a part of advertising campaigns as well, be it as a consumer (from female hygiene products to sport headscarves released by large corporations) or as an employee. This leads to different associations like 'diversity has become the new norm', or 'modern Muslimahs ${ }^{1}$ participate in all areas of life'. Naturally, this display of normality causes reactions as well. When a woman wearing a headscarf was added as an emoji, it led to public debates. Should a woman in a headscarf be displayed as 'normal' at all? Does doing so not act in support of the oppression of women?

A headscarf seems to predefine the woman wearing it to an external observer. Due to this, it is quite difficult to maintain a neutral perspective on this garment. This also poses a challenge for an impartial government. Between the principles of freedom of religion, secularity, and values such as gender equality, debates can get very heated and emotionally charged. Behind the debates stands the question of identity in an increasingly pluralistic society. The headscarf itself is effectively turned into a sort of canvas that reveals much about those who paint it with their opinions. The internal and external perception of - particularly headscarf wearing - Muslimahs are often wildly divergent.

The following article aims to illustrate the debate about the headscarf over the course of the past three decades. The topic received a varying degree of attention with narratives surrounding the headscarf developing and evolving, which in turn sometimes amplified each other while at other times being contradictory. Therefore, exemplary moments with regard to an increasing public debate on the topic will be presented. The interaction between public opinion and politics will be discussed as well. Even though an in-depth analysis of this discourse would go beyond the means of this article, particular characteristics of the debates will be pointed out in order to allow further contemplation of the topic. 


\section{Austria's Long and Laid-back Relationship with the Headscarf}

In comparison with the rest of Europe, Austria's initial stance on its Muslim population is historically unique. With the occupation and subsequent annexation of Bosnia and Herzegovina during the 19th century, around 600,000 men and women of Muslim faith became citizens of the Habsburg monarchy. This circumstance required the constitutional inclusion of the Islamic religion, which happened with the Islamgesetz (Islam Law) of 1912. Since that time, Islam has been an established religion in Austria, with all the consequences implied thereby. It was on the basis of this law that the Islamic Religious Community in Austria (Islamische Glaubensgemeinschaft in Österreich, subsequently referred to as IGGÖ) could be established as the official representative for the concerns of Muslim men and women in Austria. In this, the Austrian state has a contact organisation to engage in official dialogue. This model was proudly presented by the Austrian state to other nations, for instance through members of the IGGÖ who participated in international summits as a part of Austrian delegations.

Against this backdrop, it comes as no surprise that debates about the headscarf, like the ones occurring during the migration movements in some European states at the end of the 1980s, ended up having little to no relevance for the internal Austrian discourse on the subject, even though they were occasionally addressed. In 1999, for example, the teacher Fereshta Ludin made headlines in Germany for her attempt to reach a court ruling that would allow her to wear a headscarf while teaching in school, something that she had been prohibited from doing earlier. In 2003, France passed a general ban on headscarves in public schools. Both events were discussed in Austria as well.

\section{Headscarf Decrees by the Ministry of Education}

The approach by the Austrian ministry of education on the topic bore much more significance by comparison, as the following decree illustrates:

The wearing of headscarves, which Muslim girls (as well as women) are obligated to, falls under the religiously established dress codes under article 14 (1) StGG [Staatsgrundgesetz, Basic Law]. By contrast, there are no regulations in laws aimed at maintaining order during school operations that could be interpreted as a dress code. Church-external offices bear no authority over matters regarding religious commandments. This pertains to other re- 
ligious communities as well. Gymnastics, swimming, and domestic economy lessons are to be conducted with respect to the rules established by the Islamic faith for its members (e.g. regarding dietary rules). ${ }^{2}$

This decree illustrates the self-perception of the Austrian state: unlike in France, an awareness of secularity is present, not in a laical sense, but in the sense of secular cooperation. Church-external offices bear no authority over matters regarding religious commandments, as the above-quoted decree clearly states. For religious communities, secularity in this sense includes a right to internal autonomy regarding the interpretation of their religion. The obligation of Muslim girls (and, only in parenthesis, Muslim women) to wear a headscarf is stated as a matter of fact in the above-mentioned decree without judgement of any kind. Schools are furthermore reminded that specific lessons are to be conducted "with respect to the rules established by the Islamic faith for its members". ${ }^{3}$

\section{Protection Against Discrimination in the Workplace since 2004}

In 2004, the Austrian parliament passed the necessary adaptations to the equality laws based on EU guidelines which demanded a higher degree of protection against discrimination, including, among other things, the subject of 'religious discrimination'. Since then, it has been illegal to deny employment to a woman because of her wearing a headscarf. The Ombud for Equal Treatment, situated in the Austrian chancellery, published educational material in an attempt to sensitise on this issue. For example, the information text Kopftuch am Arbeitsplatz (Headscarves in the Workplace), which is still accessible online. It elaborates on the comprehensive protections from discrim-

2 “Das Tragen von Kopftüchern, zu dem muslimische Mädchen (bzw. Frauen) verpflichtet sind, fällt als religiös begründete Bekleidungsvorschrift unter Art. 14 Satz 1 StGG. Demgegenüber kennt das die innere Ordnung des Schulbetriebs regelnde Schulunterrichtsgesetz keine als Bekleidungsvorschrift bestimmte Art zu verstehende Norm. Die definitive Aussage betreffend religiöser Gebote steht außerkirchlichen Stellen nicht zu. Dies bezieht sich auch auf Religionsgemeinschaften. Der Turn-, schwimm- und hauswirtschaftliche Unterricht ist unter Respektierung der vom islamischen Glauben für seine Angehörigen aufgestellten Regeln (etwa bzgl. Speisevorschriften) abzuhalten". Decree issued by the ministry of education from 16 July 1992; a similar statement was released in 2004 under then minister of education Elisabeth Gehrer. The present paper has been translated from German by Florian Ksugas. The original German quotes from relevant documents are repeated in the footnotes for clarity.

3 See https://www.ots.at/presseaussendung/OTS_20040517_0TS0224/utl-kopftuch-konstruktives-gespraech-zwischen-gehrer-und-schakfeh. 
ination while also addressing the aspect of a 'neutral' appearance which some employers expect. It goes on to point out that demanding from a woman to doff her headscarf due to an expectation that consumers might react poorly to it would be illegal. In 2005, the first cases of Muslimahs who were discriminated against were picked up by the Ombud for Equal Treatment, which went on to report on them. ${ }^{4}$

Around the same time, the city of Vienna hired the first woman to wear a headscarf as a tram driver, which garnered a certain degree of attention in the media but was generally seen as a sign of diversity and reported on with a wholly positive connotation. ${ }^{5}$

This kind of legal protection makes it abundantly clear how important symbolisms of this kind can be. On the other hand, it is clear that protective measures are severely limited if the public is unable to comprehend their purpose and therefore does not support them.

\section{$5 \quad$ First Topicalisations of Headscarf Bans in Austria}

In a 2005 interview, then minister of the interior Liese Prokop stated that women have "no rights" in Islam and concluded that teachers should therefore be barred from wearing a headscarf. After a clarifying conversation with then president of the IGGÖ, Anas Schakfeh, Prokop revised her opinion. Both parties emphasised "the importance of the Austrian culture of seeking a dialogue, which is integral to the facilitation of a harmonious coexistence and mutual understanding and respect". ${ }^{6}$

During Christmas time of 2008, France's considerations of a burqa ban led to a brief debate on the issue in Austria as well. Then minister of women's affairs, Gabriele Heinisch Hosek, publicly mused on whether a similar measure might be appropriate in Austria too. ${ }^{7}$ What followed was a debate during which the IGGÖ voiced its opinions and viewpoints as well. ${ }^{8}$

The position was taken that, while there was no sympathy for the garment, an outright ban would be problematic all on its own since it

4 See https://www.gleichbehandlungsanwaltschaft.gv.at/aktuelles-und-services/aktuelle-informationen/das-kopftuch-als-hindernis-fur-die-begrundung-eines-arbeitsverhaltnisses.html.

5 See https://www.derstandard.at/story/1227289105406/nachlese-wien-erstestrassenbahnfahrerin-mit-kopftuch.

6 "In Österreich übliche Dialogkultur, die wichtig sei, um das gute Zusammenleben zu fördern und gegenseitiges Verständnis und Respekt weiter aufzubauen". See http:// religionv1.orf.at/projekt02/news/0503/ne050310_kopftuch_fr.htm.

7 See https://newsv1.orf.at/10๑118-47002/?href=https\%3A\%2F\%2Fnewsv1.orf. at\%2F100118-47002\%2F47015txt_story.html.

8 See http://religionv1.orf.at/projekt@3/news/1001/ne100108_burka.htm. 
would just be another authoritarian measure. Even more so, it could easily have adverse effects for women, such as an increased difficulty to participate in public life.

Ultimately, a consensus was reached by emphasising the right to selfdetermination for women. When the Austrian Freedom Party (Freiheitliche Partei Österreich, subsequently referred to as FPÖ) demanded a burqa ban in 2014, the minister argued strongly against the attempt, yet, at the same time, criticised the burqa as a "symbol of oppression".9

During those years, the Austrian People's Party (Österreichische Volkspartei, subsequently referred to as ÖVP) was still against restrictions on the wearing of headscarves as well. Then state secretary of integration, Sebastian Kurz, promoted measures for the empowerment of Muslim women through his department, particularly in terms of self-empowerment. He impressed participants during an advanced training course by taking more than an hour of his time for an exchange of ideas. Under the slogan "Integration durch Leistung" (Integration through Performance), women were encouraged to participate in society - the headscarf was supposed to be no obstacle. This approach can be seen in a statement by Sebastian Kurz during an interview with Armin Wolf on Zeit im Bild in 2011:

The question isn't always headscarf, yes, no, minaret, yes, no, or burqa, yes, no. These are populist topics that undoubtedly motivate people. I, however, believe that to be the wrong approach to move things forward in this matter. ${ }^{10}$

\section{Dialogforum Islam}

In 2012, during his time as secretary of state, Sebastian Kurz initiated the Dialogforum Islam. Its final report and the individual position papers of its task forces are still accessible online. Susanne Raab acted as head of the task force on gender issues. The papers are still written in the same spirit of cooperation and openness for dialogue that had been a hallmark of the approach of Austria's politics towards Islam for so many years. Challenges are pointed out but engaged as differentiated as possible, without the need for essentialist simplifications such as 'Islam' being generally at fault or responsible for a particular phenomenon. The chapter for value-related questions reads:

9 See https://religion.orf.at/v3/stories/2655643.

10 "Es geht nicht immer um die Frage, Kopftuch, ja, nein, Minarett, ja, nein, oder Burka, ja, nein. Das sind populistische Themen, die zweifelsohne Menschen bewegen. Ich glaube aber, dass das nicht der Zugang ist, bei dem man in der Sache was weiterbringen kann". See https://www.sueddeutsche.de/politik/kolumne-des-kanzlerswandlung-1.4761246. 
It was established during extensive debates on a select choice of constitutional principles and societal values that - from a fundamental political-philosophical standpoint - there are no categorically insurmountable contradictions between the values of Islam and the Austrian constitutional principles, nor between societal values and individual virtues. ${ }^{11}$

The statement by the task force includes an unequivocal commitment to the visibility of religion:

It is, in fact, far more essential for religion, which is undeniably active in public, to be present and visible in the public space, that it can, in a way, 'make itself seen', which constitutes not 'only' a core aspect of religious liberty but ultimately a 'measure to build trust' in the sense of transparency and the hermeneutical perception of religious presence in the public space as well. ${ }^{12}$

The following passage on the wearing of a headscarf is included in the chapter about gender roles.

The practice of wearing a headscarf is legally protected in Austria under the established laws securing religious liberty. The anti-discrimination law prohibits discrimination against women seeking employment or in the workplace who cover their head for religious purposes. From a formal legal standpoint, this question is therefore clearly answered. However, in everyday life, the Muslim headscarf, its symbolism, and the question about its compatibility with the fundamental values of equality between the sexes are hotly debated. ${ }^{13}$

11 "In ausführlichen Diskussionen zu ausgewählten Verfassungsprinzipien und gesellschaftlichen Wertorientierungen wurde einhellig festgehalten, dass - aus politisch-philosophischer Grundlagenbetrachtung heraus - keine prinzipiell unüberwindlichen Wertewidersprüche zwischen islamischen Normen und den in Österreich vorherrschenden Verfassungsprinzipien, gesellschaftlichen Werten und individuellen Tugenden festzustellen sind". Final report Dialogforum Islam, https://www.bmeia. gv.at/fileadmin/user_upload/Zentrale/Integration/Publikationen/DFI_ Bericht_Web.pdf, 20.

12 "Es ist vielmehr jedenfalls essentiell, dass Religion, die ja fraglos öffentlich wirksam ist, im öffentlichen Raum auch entsprechend sichtbar und zugegen ist, sich somit „sehen lassen kann“, was nicht „nur“ eine zentrale Dimension von Religionsfreiheit ist, sondern letztlich auch eine gleichsam „vertrauensbildende Maßnahme“ im Sinne von Transparenz und der damit verbundenen notwendigen hermeneutischen Erfassung der religiösen Dimension im öffentlichen Raum darstellt". Final report Dialogforum Islam, https://www.bmeia.gv.at/fileadmin/user_upload/Zentrale/Integration/Publikationen/DFI_Bericht_Web.pdf, 22.

13 "Rechtlich schützt in Österreich die gesetzlich verankerte Religionsfreiheit die Glaubenspraxis, ein Kopftuch zu tragen. Die Antidiskriminierungsgesetzgebung ver- 
Here, a certain degree of unease becomes visible. In a way, it foreshadows the lines of argument that will subsequently be used to reject the headscarf as incompatible with values such as equality and consequently restrict its use. On the other hand, there is a clear reference to the legal protection of the religious practice of wearing a headscarf.

\section{$7 \quad 2015$. The Breaking Point in Austria's Islam Policy?}

In 2015, a new Islamgesetz replaced the previous one from 1912. Originally a request from Muslims to modernise the original law, which provided too little legal security in some practical regards, the way in which people negotiated over it gradually shifted with time. During the decisive negotiation phase in the autumn of 2014, headlines were dominated by acts of terrorism committed by Daesh (The Islamic State). The Islamgesetz, originally intended to formalise rights such as spiritual welfare within the military, suddenly turned primarily into a security concern. The fact that lawmakers deemed it necessary to emphasise the priority of state rights over religious ones, whereas the same thing was considered a constitutional matter of fact for other religions, did not sit well with Muslims. It was interpreted as an expression of the worsening attitude and increasing distrust towards Muslims, resulting from the aforementioned terrorist attacks.

On top of this factor stood the high number of refugees during summer of 2015 and the fears resulting from it. Both circumstances shifted the public perception of Muslims to the negative. Right-wing populism became increasingly mainstream.

\section{Burqa Ban}

In 2017, under intense public interest, an Anti-Gesichtsverhüllungsgesetz (Law against the concealment of the face) was passed. This happened during the coalition government between the Austrian Social Democrat Party (Sozialdemokratische Partei Österreich, subsequently referred to as SPÖ) and the ÖVP. It was part of an integration law. 'Soft' measures, favoured by the SPÖ, received the support 
of the ÖVP. In turn, the SPÖ supported the law which became subsequently known as the "burqa ban".

Whoever covers or conceals his or her facial features with clothing or other objects in public places or in public buildings in a manner so that these features can no longer be recognised, commits an administrative offence and must be fined $€ 150 .{ }^{14}$

The term which became traditionally associated with the law - "burqa ban" - is clearly informative of the intention of the law. A burqa, i.e. the garment most commonly associated with Afghanistan where it was forced upon women by the Taliban, is in some ways reminiscent of a 'wearable prison' due to its cage-like web concealing the face, while the rest of the body is covered in such a complete way that even physical features become indistinguishable. Many Muslims view it in a negative light as well. Women wearing a burqa were and are non-existent in the streets of Austria. Muslimahs who cover their face beneath their eyes use a niqab, like the ones found in the Gulf States. In fact, most women wearing a face veil were tourists from these countries. Therefore, it comes as no surprise that the law's date of entry into force was postponed from June to October in order not to endanger the tourist season.

The term burqa provides an opportunity to convey the ban as a measure for the 'liberation of women', even though, in practice, there are no burqa-wearing women living in Austria. The law was repeatedly referred to as a 'token law' due to its relatively obvious intention of sending a signal to parts of the population who demanded a more determined approach against Islamic terrorism on the part of the government. In this, authority could be displayed, and the message conveyed: 'We are the masters in our own home'. The obvious populism involved in the matter became secondary, not least because virtually no one feels sympathy towards women wearing a face veil.

Before the law came into effect, the headscarf in general was the subject of public debate as well. The ban ultimately affected 'only' the face veil, however women wearing headscarves felt a general increase in the societal pressure imposed upon them. Even the Federal President addressed the issue:

14 "Wer an öffentlichen Orten oder in öffentlichen Gebäuden seine Gesichtszüge durch Kleidung oder andere Gegenstände in einer Weise verhüllt oder verbirgt, dass sie nicht mehr erkennbar sind, begeht eine Verwaltungsübertretung und ist mit einer Geldstrafe bis zu 150 Euro zu bestrafen". See https://www.parlament.gv.at/PAKT/VHG/XXV/ME/ ME_00290/imfname_614755.pdf. For the English version see https://ris.bka.gv.at/ Dokumente/Erv/ERV_2017_1_68/ERV_2017_1_68.pdf. 
And if things continue like this, what with all this actually spreading Islamophobia, we will see the day where we have to ask every woman to wear a headscarf. Everyone, in solidarity with those, who do so for religious purposes. ${ }^{15}$

Alexander van der Bellen expressed these words during a youth event. The exaggerated wording drew a lot of criticism. In the context of his speech, it was obvious that he was deliberately exaggerating, naturally in solidarity with headscarf-wearing women.

This is not the place to attempt a detailed analysis of the various contributions to the debate at the time. Women from the feminist community were often unable to identify with the loud calls for a headscarf ban, as can be illustrated in a statement by Elfriede Hammerl in the weekly newspaper Profil from 27 May 2017:

Those who protest the loudest against the headscarf have less to do with women's rights than a traditional Saudi sheikh. They scream and swear both against the strive for equality, which they call gender madness, and against migrant women, whose fault they don't perceive in their attitude towards women's politics but simply in that they are migrants. They use women's rights as a pretext to live out their xenophobia. ${ }^{16}$

The law was, likewise, often associated with symbol politics.

The European Court of Human Rights has been quite clear in its judicature. A restriction of religious liberties is permissible to ensure the principles of 'living together', as can be read in a judgement from July 2017, which confirmed an earlier ruling that reached the same conclusion in $2014 .{ }^{17}$ It goes on to elaborate that the acceptance of a full-body veil was a decision up to society and that individual nations could make situational decisions according to their evaluation. This begs the question, which was asked in the commentaries at the time as well, whether the ECHR awards less significance to religious rights and liberty than to other interests, such as social in-

15 "Und wenn das so weitergeht, bei dieser tatsächlich um sich greifenden Islamophobie, wird noch der Tag kommen, wo wir alle Frauen bitten müssen, ein Kopftuch zu tragen. Alle, als Solidarität gegenüber jenen, die es aus religiösen Gründen tun”.

16 "Diejenigen, die am lautesten gegen die Verschleierung protestieren, haben mit Frauenrechten weniger am Hut als ein gestandener saudischer Scheich. Sie stänkern und pöbeln einerseits gegen Gleichstellungsbestrebungen, die sie Genderwahnsinn nennen, und andererseits gegen Migrantinnen, an denen sie nicht deren eventuelle frauenpolitische Positionierung stört, sondern nur, dass sie Migrantinnen sind. Sie schieben die Frauenrechte vor, um ihre Fremdenfeindlichkeit auszuleben". See https://www. profil.at/meinung/elfriede-hammerl-kopftuch-8165642.

17 See https://www.sueddeutsche.de/panorama/urteil-in-strassburg-vollverschleierung-ist-kein-menschenrecht-1.3582881. 
tegration. Whether the interests in this matter are actually contradictory - particularly with regard to the headscarf and not the face veil - is essentially not addressed at all. However, this is likely the core of the problem: the headscarf is vilified from an external standpoint and declared as a symbol of the conscious rejection of gender equality. According to this logic, a woman without a headscarf is 'integrated' while one with a headscarf has trouble with social integration. From the perspective of women who do wear headscarves, it is the other way around. They view themselves as fully capable of integration and perceive the pressure to doff the headscarf not as 'social integration' but as discrimination.

\section{Ban on Headscarves at a Kindergarten Age}

On 18 December 2017, the coalition government between the ÖVP and the FPÖ was sworn in under chancellor Sebastian Kurz. It was to be expected that, under an FPÖ minister of the interior, populist demands such as "Stopp der Islamisierung" (stop Islamisation) would become factual measures. The ÖVP for its part had repeatedly issued opinion polls, for example in conjunction with the parliamentary survey on the subject of Leitkultur (dominant culture) in November 2016. In doing so, the party determined which things the public would demand from immigrants based on the debate on values which had been instigated by the ÖVP itself. Muslim men and women were the object of particular attention here as well.

Vague terms like 'Islamisation' are well suited to stir underlying fears of Überfremdung (domination by foreign influences) - to quote yet another term from the FPÖ playbook - and to mobilise all those who feel that 'Islam does not belong to Austria'. In its vagueness, however, there is naturally no clear line as to where the border of simply practicing what is after all an officially recognised religion in Austria and a perceived encroachment on the identity - or at least supposed identity - of the state of Austria lies, nor when such a matter should be persecuted as an attack on the state or its constitution. Already in 2005, the FPÖ put up billboards reading "Freie Frauen statt Kopftuchzwang" (free women instead of compulsory headscarves), indicating that the blond, blue-eyed women displayed on the billboards were free and 'genuine Austrian women', whereas every woman wearing a headscarf was automatically oppressed. Since then, this view has been repeated so many times that it has been able to take an increasingly unopposed hold of people's opinions. Incidentally, the personal culture and religion of the followers of this ideology are elevated to a higher status in the process as well. The headscarf was, once again, abused as a projection surface for various messages with the intention to agitate and mobi- 
lise. The ÖVP, for its part, had already established through surveys that a ban on headscarves would find approval among its voters.

Before this background, it comes as no surprise that, following the initial establishment of a ban, more measures aimed at the headscarf were to follow. In November 2018, a ban on headscarves in kindergarten was passed according to a $15 \mathrm{a}^{18}$ agreement regarding preschool and kindergarten education between the state and its federal provinces. The core issue was a lot of money for the federal provinces, with the headscarf ban playing only a minor role. As such, it was voted for by the opposition parties as well, although naturally not without critical notes. ${ }^{19}$

During the evaluation procedure, multiple organisations came out against a headscarf ban. Repeatedly, the argument was made that the measure constituted an unlawful interference into fundamental rights and that, in doing so, a political debate on integration was fought out on the backs of small children. The IGGÖ issued two statements. One aimed mostly at the judicial aspect of the matter, while the women's representatives were mostly concerned with education and the societal consequences of the measure ${ }^{20}$ From a Muslim perspective, the discriminatory nature of the measure was a particular object of criticism. The headscarf itself, so ran the argument, was put under suspicion, implying that children needed protection from their own parents in order not to be forced to wear it.

None of these statements were taken into account. When a law banning the wearing of headscarves in primary schools was initiated a few months later, no chance for statements during an evaluation procedure took place, nor was any opportunity for the issuing of statements provided at all.

\section{Headscarf Ban in Primary Schools}

Unsurprisingly, efforts for an extension of the ban on headscarves in kindergarten to include schools, initially primary schools, followed immediately in the wake of its passing. While a ban on headscarves in kindergarten affected essentially no one, since a headscarf during those ages has no relevance from an Islamic standpoint and is

18 A 15a agreement is a treaty between the federal government and the provinces.

19 See https://www.parlament.gv.at/PAKT/PR/JAHR_2018/PK1311.

20 See the commentaries of the IGGÖ: https://www.parlament.gv.at/PAKT/VHG/XXVI/SNME/SNME_02483/imfname_714110.pdf and of the department for women's affairs of the IGGÖ: https://www.parlament.gv.at/PAKT/VHG/XXVI/SNME/SNME_02564/imfname_714402.pdf. 
not worn as such, a ban in the case of primary school age children was far more complex.

In general, the headscarf from a theological standpoint only becomes a question for religious women of age. However, it is not unknown for younger girls to wish to wear the garment out of their own accord, especially during the transitional period between primary school and middle school. This topic had been engaged and debated within Muslim communities for decades. These processes had contributed to the critical dissection of standpoints that welcomed the early wearing of a headscarf as 'habituation' if the desire to wear the garment originated from the girl herself. The rejection of coercion had already been the established mainstream opinion. At the same time it was discussed in an awareness-raising way, that a girl who had begun to wear a headscarf but did not end up comfortable with her decision - for instance due to discrimination - was entitled to unequivocal support in her decision to doff the garment again. These viewpoints were intended as a rebuke to attitudes within the Muslim community that effectively equated the wearing of the headscarf with a profession of faith and the doffing of it with a rejection of the faith itself.

This internal Muslim debate is mentioned, among other things, to illustrate that the legislative ban utterly ignored these positive strategies to safeguard the interests of young girls within Muslim communities. As with the ban on headscarves in kindergarten, the lawmakers conveyed the message that Muslim parents needed a law to 'teach' them how to appropriately raise their children with regard to Islamic garments. The majority of the population, in turn, can interpret such political measures as a way to preserve the Austrian identity and aiming at 'the others'.

The governing parties voted for a ban on headscarves until the age of ten in primary schools on 16 May 2019, a few weeks before the implosion of the ÖVP-FPÖ coalition in the wake of the Ibiza scandal. The opposition parties voted against the measure, pointing out the need for real integration measures instead. No broad parliamentary debate had taken place. A procedure before the educational committee had been postponed several times. When a hearing finally did take place, no representatives of the IGGÖ and/ or headscarf-wearing Muslimahs, who could have at least spoken from the viewpoint of those affected by the law, were invited. The official representation of Muslims was ignored just like the general Muslim population. Only people who supported the viewpoint of the governing parties and a ban were invited. Zana Ramadani is quoted here as an example: 
It [the hijab] likewise represents an inhuman ideology, it stands for gender apartheid and therefore for sexism and the fundamentalist, political, conservative Islam. ${ }^{21}$

This one statement encapsulates virtually every common attribution to and prejudice against the headscarf.

The Schulunterrichtsgesetz (School Education Act) was amended with the following passage, which states a ban on headscarves in the following way:

The School Education Act, BGBl. Nr. 472/1986, at the last time amended by Federal Law BGBl. I Nr. 35/2018, is amended as follows:

1. After article 43, article 43a is added:

$\S 43 a$.

(1) To ensure the best possible development and growth for all pupils, they are prohibited from wearing any kind of garment bearing ideological or religious connotations that involves the veiling of the head until the age of 10 . This serves the social integration of children according to local customs and practices, the preservation of constitutional values and the educational goals of the federal constitution, as well as the equality between man and woman.

(2) In case of a violation of the law according to section 1 , the school principal has to inform the appropriate department of education immediately. The department has to summon the legal guardians to a mandatory dialogue immediately, within 4 school days at the latest. During this dialogue, the reasons for the violation are to be discussed. As a prevention of further violations, the legal guardians are to be informed of their responsibilities; this is to be recorded in written form and the school principal is to be made aware of the procedure.

(3) Another violation according to section 1 following this dialogue, or failure by the legal guardians to comply with the mandatory summoning after a second call, represent an administrative offence by the legal guardians, punishable by the district administrative authority with a fine of up to $€ 440$ or, in the case of an impossibility of collection, two weeks of imprisonment as an alternative. ${ }^{22}$

21 "Er [der Hidschab] steht ebenfalls für eine menschenverachtende Ideologie, für Geschlechterapartheid und damit auch für Sexismus sowie fundamentalistischen, politischen, konservativen Islam".

22 "Das Schulunterrichtsgesetz, BGBl. Nr. 472/1986, zuletzt geändert durch das Bundesgesetz BGBl. I Nr. 35/2018, wird wie folgt geändert:

1. Nach $\S 43$ wird folgender $§ 43$ a angefügt:

$\S 43 a$. 
A circular by the ministry of education (full name: Bundesministerium für Bildung, Wissenschaft und Forschung) subsequently informed of practical aspects, picking up wordings that had already been found in the draft law.

This regulation aims at the way a garment is perceived by an objective observer. The personal intentions of the wearer are irrelevant in this regard. What matters is the perception of a third party. Therefore, the individual reasoning of the wearer or her parents in case of a violation are irrelevant. Only the offence, i.e. the "veiling of the head", is of relevance. ${ }^{23}$

The wearing of a headscarf becomes an "offence". Any kind of dialogue about it is unwelcome. The intentions of "the wearer" (interestingly, the German text utilises the masculine gender in this case) is irrelevant before the 'perception of third parties', who are viewed as 'objective observers'. In this, outside observers are granted the authority to judge the innermost motivations of a religious practitioner, effectively a disenfranchisement of the affected individuals. One could argue that the matter revolves around minors. However, the UN Convention on the Rights of the Child, which has been ratified in Austria, clearly states in article 12 that children are to be heard and

(1) Um die bestmögliche Entwicklung und Entfaltung aller Schülerinnen und Schüler sicherzustellen, ist diesen bis zum Ende des Schuljahres, in welchem sie das 10. Lebensjahr vollenden, das Tragen weltanschaulich oder religiös geprägter Bekleidung, mit der eine Verhüllung des Hauptes verbunden ist, untersagt. Dies dient der sozialen Integration von Kindern gemäß den lokalen Gebräuchen und Sitten, der Wahrung der verfassungsrechtlichen Grundwerte und Bildungsziele der Bundesverfassung sowie der Gleichstellung von Mann und Frau.

(2) Bei Verstoß gegen das Verbot gemäß Abs. 1 hat die Schulleiterin bzw. der Schulleiter unverzüglich die jeweils zuständige Bildungsdirektion zu verständigen. Diese hat die Erziehungsberechtigten unverzüglich, jedenfalls innerhalb von 4 Schultagen, zu einem verpflichtenden Gespräch zu laden. In dem Gespräch sind die Gründe für den Verstoß zu erörtern. Zur Vermeidung weiterer Verstöße sind die Erziehungsberechtigten über ihre Verantwortung aufzuklären; dies ist schriftlich festzuhalten und der Schulleiterin bzw. dem Schulleiter zur Kenntnis zu bringen.

(3) Findet nach dem Gespräch ein weiterer Verstoß gegen das Verbot gemäß Abs. 1 statt, oder kommen die Erziehungsberechtigten der verpflichtenden Ladung nach nochmaliger Aufforderung nicht nach, so stellt dieser eine Verwaltungsübertretung durch die Erziehungsberechtigten dar und ist von der Bezirksverwaltungsbehörde mit einer Geldstrafe bis zu 440 €, im Fall der Uneinbringlichkeit mit Ersatzfreiheitsstrafe bis zu zwei Wochen zu bestrafen".

23 "Die Regelung stellt darauf ab, wie eine Bekleidung von einem objektiven Betrachter wahrgenommen wird. Es kommt dabei nicht auf die persönliche Absicht des Trägers an. Entscheidend ist, wie diese von Dritten rezipiert wird. Im Fall von Verstößen ist daher eine individuelle Begründung der Trägerin oder der Eltern unerheblich. Es kommt ausschließlich auf die Erfüllung des Tatbestandes der 'Verhüllung des Hauptes' an". From circular Nr. 17/2019 for the implementation of article 43 SchUG "Kopftuchverbot" (headscarf ban). 
allowed to express their views freely in all matters affecting them..$^{24}$ Parents are entirely ignored as well. The contradiction between the section declaring the goal of the Austrian school system and the explicit demand for an education aimed towards 'maturity' also bears mentioning since it is precisely these goals that are expressed in the educational aims of the federal constitution, even though this can easily be interpreted as a blatant contradiction. ${ }^{25}$

The entire argument hinges on the attempt to create a contradiction between the headscarf and Austrian values. A resolution proposal by the ÖVP during autumn of 2019 illustrates this point further:

A further step shall implement a headscarf ban for girls until the age of 15 (tied to the reaching of religious maturity). The reasoning for this is that the headscarf is not simply a religious symbol, but a political symbol particularly associated with the oppression of women and girls. ${ }^{26}$

The choice of words referring to the headscarf as a "political symbol" is remarkable. This wording falls in line with the ÖVP's advances against "political Islam", without defining the term further - similar to what the FPÖ had already attempted with the term "Islamisation". "Political Islam" seems to provide the advantage of any measures against it being primarily political in nature, instead of blanket measures against an entire religious community. The goal, so the reasoning, is simply to counter abusive tendencies that could carry elements potentially in violation of the constitution. Yet, again, everything remains vague enough that even simple religious practices and particularly the visibility of them can be interpreted as conspicuous. A headscarf ban was, once again, considered an appropriate measure to show determination in the "fight against political Islam". Susanne Raab, minister for integration and women's affairs, announced the intention to implement an extension to the headscarf ban during the first one hundred days of the new government at the beginning of 2020 .

24 See the UN Convention on the Rights of the Child, § 12, https://unicef.at/fileadmin/media/Kinderrechte/crcger.pdf.

25 Magdalena Hubert's work Der Wertewandel in der österreichischen Gesellschaft im Kontext der Schulgesetzgebung shall be specifically mentioned in this context: https://rdb.manz.at/document/rdb.tso.LIsundr20130204.

26 "In einem weiteren Schritt soll die Umsetzung eines Kopftuchverbots für Mädchen bis zum vollendeten 14.Lebensjahr (geknüpft an das Erreichen der Religionsmündigkeit) erfolgen. Der Grund dafür ist, dass das Kopftuch nicht nur ein religiöses Symbol ist, sondern vor allem auch ein politisches Symbol, das insbesondere die Unterdrückung von Frauen und Mädchen zum Ausdruck bringt". 


\section{Muslim Attempts to Participate in and Influence the Debate}

Apart from numerous contributions over the course of the debate in the media, two quite different approaches to influence the debate about, and perhaps prevent a ban on headscarves, shall be illustrated.

During the presidency of Ibrahim Olgun from June 2016 to December 2018, the superior council of the IGGÖ debated the possibility of calling a fatwa on the wearing of the headscarf. The underlying logic was to unequivocally establish the wearing of a headscarf as such an integral part of religious practice that any attempt to prohibit it would have constituted an interference with internal matters of the religion and therefore a violation of religious liberty. What was overlooked in this approach was the fact that, within Muslim self-conception, a fatwa is always intended as a clarification of a question regarding religious practices posited by Muslim men and women, in a way an expert opinion, which the faithful can choose to abide by or not. This fatwa, however, was primarily intended for the non-Muslim public. Even the theological debate of a fatwa may be hard to grasp for outsiders. Ultimately, the authors of the fatwa also made the mistake of speaking of a 'commandment' to wear a headscarf, believing that, in doing so, they would empower Muslim women in their rights. Even though the right to self-determination was never questioned, there was always the peril of creating the impression that Muslim women should be forced to wear a headscarf - particularly by selectively quoting the report. This, of course, would have reinforced the exact arguments postulated by opponents of the headscarf, namely that it is never done out of a woman's own volition. The actual intention to save women the indignity of having to justify themselves and to turn the wearing of a headscarf into an inconspicuous part of religious practice would not have been accomplished in this way.

While the text itself was written, it was only published on the IGGÖ’s website. However, it was only a matter of time until the media would find it and spin a story out of it. This happened in February 2017, drawing some very heated reactions. Both then minister of integration, Sebastian Kurz, and state secretary for religion, Muna Duzdar, publicly rejected the fatwa. ${ }^{27}$

The IGGÖ's speaker for women's affairs took International Women's Day as an opportunity to publicly question the fatwa's usefulness. ${ }^{28}$ By now, the text has been removed from the IGGÖ's website.

27 See https://religion.orf.at/v3/stories/2829312.

28 See https://www.diepresse.com/5179731/islam-interner-konflikt-um-kopftuchgebot. 
After a year, the issue of the headscarf was still present in the public, with bans being actively planned. In response, the IGGÖ's advisory council was summoned to consider measures that might cause politicians to reconsider their position. Eventually, and concurrently with a declaration by several imams against terrorism and violence, which had received incredibly positive public feedback, the idea to initiate a women's declaration arose. The task was entrusted to the IGGÖ's women's representative and Zaynep Elibol, director of the Islamische Fachschule für soziale Bildung (Islamic College for Social Education) who had many years of experience in community work and inter-religious dialogue.

A broad dialogue was initiated among Muslim women with the goal of formulating a text that would be able to represent the views and positions of Muslimahs in all their variety truthfully and authentically. A whole series of meetings was scheduled to achieve as much participation as possible and to gather all views presented. Ultimately, a three-part declaration that focused on the right to self-determination of women, regardless of whether they wore a headscarf or not, was formulated. Initially, demands aimed at the Muslim community itself are stated, such as the expectation of the realisation of resolutions of the imam conferences that revolve around equality and the full participation of women. Women shall communicate about the headscarf themselves. Another part analyses common attributions to and prejudices against the headscarf and attempts to deconstruct them. It was also of importance to the women to reflect on the understanding of their own role within important social positions and to transmit a form of self-description. The theological background of the headscarf was not addressed. This decision was made to avoid the appearance of trying to justify the wearing or not-wearing of the headscarf and instead put the emphasis on the right to self-determination.

Potential signatories were deliberately sought out through personal contact instead of social media or a webpage. Through this, a dynamic that elevated Muslim women to active participants was achieved. Thousands of women from all kinds of backgrounds, of different ages, and various levels of education participated. Ultimately, this also meant a revival of the internal Muslim dialogue and an affirmation against external labels, as well as an expression of solidarity between women in all their diversity. The presentation took place on 12 March 2019 under the slogan Musliminnen am Wort (Muslimahs having the word). ${ }^{29}$

The declaration received attention in the media and was sent to mandataries of political parties as well. This led to some productive

29 See http://www.forum-muslimische-frauen.at/index.php?page=deklarationmuslimischer-frauen. 
conversations, albeit not on the part of the governing parties, who ignored the declaration. The Österreichische Liga für Menschenrechte (Austrian League of Human Rights) addressed the topic in its annual report. ${ }^{30}$

Already during the gathering of signatures, it was important to convey a realistic assessment of the situation to allow for the setting of achievable goals. Within the frame of the current debate, breaking certain narratives surrounding Muslim women appears to be particularly difficult. Therefore, there was no intention to succumb to the illusion that the declaration would have any chance of stopping the prohibitionist policies. That is, ultimately, also a question of power. Due to this, a complex debate about the headscarf would be excellently suited for a study inspired by the works of Michel Foucault. Naturally, the driving forces for the women were their own dignity and their understanding of themselves. Even the act of rising to speak conveys a form of personal empowerment. Displays of solidarity by others, among them quite well-known opinion leaders, felt reassuring and vindicating. Coming to understand certain facts may very well help to facilitate patience, especially the realisation that bans on headscarves revolve around a whole plethora of interests, yet least of all around an honest interest in those affected by them.

During the process of establishing their declaration, the Muslimahs involved also reflected on the issue that the headscarf is not simply a source of friction for "external" sources. Muslim people react at least as emotional when confronted with the issue which does, after all, revolve around a visible piece of identity. Even more than that, it must be honestly admitted that, from an internal Muslim perspective, the headscarf is often seen and utilised as a sign of identity (particularly by men). Here, the evolution of ideological restrictions, that have the potential to yet again limit women in their self-determined appearance by predefining their choices, are a distinct possibility as well. If the mentality could be reinforced within Muslim communities, that a simple equation like 'the headscarf equals pure and pious' is not admissible, and that the act of not wearing a headscarf does not imply the opposite either, it would already represent a significant victory.

Last but not least, the debate also proves to be as difficult as it is because the arguments of the proponents of a headscarf ban cannot be simply dismissed as completely unfounded. Wherever girls or women are forced to wear a headscarf, a determined intervention for their right to self-determination is absolutely necessary. Just as an ostensibly positive attribution to the headscarf may ultimately miss what the wearer herself associates with it. The visibility of the headscarf is part of its nature. What should not be are the ideologi- 
cal attributions associated with it - whether demonised as a 'symbol of oppression' or elevated to the 'symbol of a decent woman' and the various negative implications directed at women without it.

\section{Outlook}

A lawsuit filed by the IGGÖ on behalf of two families, one Sunni and one Shiite, before the Constitutional Court of Austria at the beginning of 2020 has yet to be decided at the time of this writing. ${ }^{31}$ The decision has already been adjourned multiple times. This may be taken as an indication that even the constitutional judges are having some trouble with the topic. The European Council expressed criticism in June 2020 and demanded a revision of the headscarf ban, which will likely be taken into consideration as well. The European Council had quite clear words:

There are high levels of Islamophobia and the public discourse has become increasingly xenophobic. Political speech has taken on highly divisive and antagonistic overtones particularly targeting Muslims and refugees. ${ }^{32}$

While headscarf bans had already been legally challenged in other European nations over the past years, Austrian Muslims have now reached a point where they feel the need to reach a constitutional conclusion as well. On the one hand, this can be regarded as a positive sign for the proper functioning of the democratic processes in a constitutional state. On the other hand, there are several problems tied to this approach as well. An attempt to lift the ban on headscarves in primary schools would have to be argued on the basis of the parents' right to educate their children. However, there is no intention whatsoever to inadvertently establish the authority for parents to force their daughters to wear a headscarf either. Since no one intends to reach a judgement that would be detrimental to Sikhs or Jewish people by potentially extending the ban on their head coverings as well, the argument that a specific ban of the Muslim headscarf is in violation of the principle of equality is similarly problematic.

In Germany, the Federal Constitutional Court has already decided in 2015 that a general ban on headscarves for teachers in schools is

31 In December 2020 the Constitutional Court struck down the law. See https://www. bbc.com/news/world-europe-55277840.

32 "Es gibt einen hohen Grad an Islamophobie, und der öffentliche Diskurs ist immer fremdenfeindlicher geworden. Politische Reden haben äußerst spaltende und antagonistische Grundtöne angenommen, insbesondere in Bezug auf Muslime und Flüchtlinge". See https://orf.at/stories/3167962. For the English version see https://rm.coe. int/report-on-austria-6th-monitoring-cycle-/16809e826f. 
unconstitutional. Its line of argument is of particular interest against the backdrop of the Austrian emphasis on an "objective observer" within the legal framing of the headscarf ban, which supposedly makes listening to the wearer herself unnecessary:

If it were established that "the wearing of a headscarf could be objectively understood as a sign of support for the unequal treatment of man and woman, including from a legal standpoint, and that the wearer of the headscarf would therefore need to be questioned in her eligibility to an educational profession", then this would, according to the court, constitute a generalised suspicion and would not be sufficient for a restriction of religious liberties. ${ }^{33}$

Austria used to have a long-standing tradition of resolving matters pertaining to a harmonic coexistence through dialogue. Issues such as the headscarf are a form of placeholder for various issues that need to be resolved. Often, personal experiences will lead to generalisations about Muslims that are not always accurate. If the headscarf is viewed, from an external standpoint, as a symbol of patriarchal oppression while also keeping in mind that the achievement of many women's rights in Austria is recent enough to justify fears of losing them again, especially since true equality has not even been reached yet, then the emotions tied to the headscarf on the Muslim side become much more relatable. At the same time, the fact that Muslim women are often forced to justify themselves regularly stifles a meaningful debate between equals. This is not only tiring for Muslimahs who are forced to repeatedly prove their trustworthiness and earn people's respect. Those who feel that they can only keep the company of a Muslim woman once she has satisfactorily elaborated her view on her headscarf likewise limit their chances of making new acquaintances.

It is far more expedient, as examples from inter-religious and inter-feminist dialogues demonstrate, to tackle issues like gender equality together. Then, it also becomes possible to overcome certain framings, i.e. prejudices that lead us to label each other based on assumptions, and to become more open for and attentive to each other. This should be the point from which one should set out on the way back to beneficial and fact-based debates.

33 "Wenn vereinzelt geltend gemacht werde, 'im Tragen eines islamischen Kopftuchs sei vom objektiven Betrachungshorizont her ein Zeichen für die Befürwortung einer umfassenden, auch rechtlichen Ungleichbehandlung von Mann und Frau zu sehen und deshalb stelle es auch die Eignung der Trägerin für pädagogische Berufe in Frage', dann sei dies, so der Senat, ein Pauschalverdacht und für die Einschränkung der Glaubensfreiheit nicht hinreichend". See https://www.faz.net/aktuell/feuilleton/karlsruherbeschluss-kopftuch-na-und-13481717.html. 



\title{
The Headscarf as a Discursive Battlefield Positions of the Current Discourse on Muslim Veiling in Austria and Germany
}

Gabriel Malli

Universität Graz, Österreich

\begin{abstract}
Practices of Muslim female veiling are a frequent object of concern in the political debate in Austria and Germany. Reviewing current empirical and theoretical literature on the issue, I will try to trace relevant positions of the current debate employing a theoretical framework based on poststructuralist discourse theory. As I want to show, dominant discursive positions frequently refer to the oppressive element of the headscarf, understand it as opposed to shared 'Western' values or interpret it as an element of a process of Islamisation. Other, often marginalised speakers try to constitute veiling as a matter of freedom of religion, as a spiritual endeavour or as an act of resistance. Many of the positions represented in the public discourse, I argue, tend to overlook the variety of experiences Muslim women face at the intersection of various forms of dominance, and make invisible some of the multiple layers of meaning the practice of veiling is imbued with.
\end{abstract}

Keywords Headscarf. Headscarf debate. Veiling. Hijab. Islam. Discourse. Discourse analysis.

Summary 1 Introduction. - 2 On the Notion of Discourse. - 3 Literature on the Topic. - 4 The Headscarf in Mainstream Politics. - 4.1 Oppression and Individual Danger. - 4.2 Islamisation and Social Danger. - 5 Questioning Hegemonies. - 5.1 Hijab as an Expression of Autonomy and Religious Pluralism. - 5.2 Hijab as a Religious Symbol. - 5.3 Headscarf as a Symbol of Resistance. -6 Conclusive Remarks. Towards an Intersectional Approach to Veiling? - 7 Appendix. Notes on the Performativity of Discursive Knowledge. -7.1 Challenging Dominant Discourses... $-7.2 \ldots$ and Repairing Them. - 7.3 Conclusive Remarks. 


\section{Introduction}

For more than twenty years, practices of Muslim female veiling have been a prominent issue in public debates of German-speaking countries, starting with the controversy around the Stuttgart teacher Fereshta Ludin in the late 1990s: with reference to the principle of religious neutrality of state education, courts forbade her to teach with a headscarf in a public school, resulting in a year-long legal dispute in which Ludin tried to claim her right to do so. ${ }^{1}$ Since then, the Muslim veil regularly returns into the political arena as an object of concern. Discussions, however, go far beyond the garment and its religious meanings: instead, the headscarf inhibits the status of a 'floating signifier' pointing at broader normative social concepts and issues, such as secularity, freedom of religion, gender equality or migration. Not least, those debates allow for insights into the selfunderstanding of a non-Muslim majority society as well as into their relationships to an 'other' marked as Muslim. ${ }^{2}$

Even during the COVID-19 pandemic in 2020 the privileged status of the headscarf as a signifier in political discourse became evident: especially right-wing populist politicians mobilised the headscarf as a symbol for criticising Corona-related measures as oppressive. Constructing parallels between mandatory face mask wearing and an alleged pressure for veiling in Muslim milieus, the German member of parliament Ulrike Schielke-Ziesling from the right-wing AfD remarked in a blog entry in April 2020 that obligatory masks "give a small insight into the everyday life of millions of Muslim women". ${ }^{3}$ In the same context, Dominik Nepp, the Viennese chairman of the nationalist-conservative Austrian Freedom Party, referred to the mask as a "governmental burqa" on a demonstration against federal Coronapolicies in May 2020. ${ }^{4}$ Detaching the veil from any religious context and re-signifying it as a general symbol of unfreedom and oppression, those instances again point at the complex sociopolitical layers of meaning the headscarf is imbued with.

This article primarily aims at tracing and contextualising regularities and recurring statements in contemporary debates on the headscarf. After a short explication of the notion of discourse and a brief review of relevant literature, I try to reconstruct dominant ascriptions to the headscarf in a first step, taking into account theoretical and empirical analyses from the German-speaking scientific discourse of the last twenty years. With 'dominant' I here refer to

1 Schieder 2005.

2 Amir-Moazami 2007, 16-17.

3 Schielke-Ziesing 2020. Unless otherwise stated, all translations are by the Author.

4 ORF Wien 2020. 
statements which take central positions in the discourse, are broadly recognised as true and, not least, are translated into concrete policies. In a second step I want to make visible the often marginalised positions questioning dominant meanings and offer alternative readings to the practice of veiling. I would like to remark that my aim is neither the reconstruction of the historical development of these positions, nor a systematic empirical analysis of current debates. Instead, I try to offer an overview on a tense and affectively charged discursive field, which can function as a basis or orientation for future scholarly work on the subject.

\section{On the Notion of Discourse}

First of all, I want to give some specifications on the notion of discourse: following Foucauldian lines of thought, I understand discourse as an abstract system of statements and knowledge forms about an object, embedded in a specific sociohistorical constellation. ${ }^{5}$ Comprising orders of classification and evaluation as well as concrete narratives and interpretation frames, ${ }^{6}$ such systems allow for the social intelligibility of their objects. Consequently, a discourse defines what can be said about an object at a specific historical point. What I do not mean when I talk about discourse is a process of democratic and rational negotiation in the public sphere, as implied by a Habermasian concept of discourse. ${ }^{7}$ Instead, I assume that discourses play out in a field of conflict and tension on which agents with divergent interests and resources constantly struggle for the power of interpretation and definition. Trying to establish hegemonies and to set certain statements as true and absolute, dominant agents seek to exclude speakers producing deviant knowledge from legitimate speech by means of different mechanisms of regulation and control. ${ }^{8}$

In this sense, the contemporary discourse on the headscarf in Germany and Austria can be described as a complex of knowledge forms which classify and evaluate the practice of Muslim veiling and thus constitute it as a 'problematic' object in need of negotiation. Empirically, such a discourse becomes graspable in many linguistic and semiotic events, such as spoken and written texts, but also visual media and performative action, in public, as well as in non-public contexts. Generally, those discursive 'fragments' form a system of dispersion with

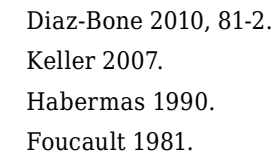


specific regularities and densifications emerging. ${ }^{9}$ This also holds for the discourse on veiling which densifies in public debates and in which certain speakers and statements are put forth in privileged positions.

Finally, the question about direct and indirect effects of discursive events is an empirical one: it would be a failure to assume that discourses automatically produce social order and are mechanically translated into follow-up action, but clearly they exert power on subjects, encourage certain practice forms and prevent others. ${ }^{10}$ Furthermore, they materialise in so-called dispositives - ensembles of heterogeneous elements such as legal arrangements, institutions or architecture - which solidify certain forms of knowledge and power relations. ${ }^{11}$ Concrete legislative restrictions for veiled women thus can be understood as elements of such a dispositive which on the one hand are informed by a certain discursive knowledge, and on the other hand support and actualise this knowledge.

\section{Literature on the Topic}

The public and political debates on the headscarf of the last twenty years motivated a series of scholarship informed by concepts of discourse analysis in German-speaking countries. From the mid-2000s studies emerged primarily in the sociological academic context, but also in cultural, religious and legal studies, as well as in political sciences. I want to give here a brief review of the current research. In almost any case, scholars stress that headscarf debates point at broader normative social questions: in her pioneering study, Oestreich (2004) interprets the debate around Fereshta Ludin as a struggle between the conflicting political ideals of secularity on the one hand, and religious pluralism on the other. ${ }^{12}$ Also Schieder (2005) emphasises that the headscarf debate must be located in the intersection of political, legal and pedagogical discourses on the role of religion in an allegedly secularised society. ${ }^{13}$ Armenkow (2009) analyses the headscarf as a "projection theatre" in which boundaries between the "West" and the Islamic or oriental other are actualised and re-negotiated. ${ }^{14}$ Similarly, Amir-Moazami (2007) in her extensive comparison of the German and the French discourse on veiling shows how the headscarf and its alleged layers of meaning are con-

9 Foucault 2004, 41.

10 For the relation of discourse and practice see Butler 1997.

11 Foucault 1978, 119-20.

12 Oestreich 2004.

13 Schieder 2005, 19.

14 Armenkow 2009, 136. 
stituted as contradictory to shared national values. ${ }^{15}$ In a later paper (2014) she argues that headscarf controversies must also be considered performative processes drawing affective boundaries between veiled and "secular" bodies. ${ }^{16}$ Investigating the symbolism of the veil in dominant discourses on migration Jäger and Jäger (2007) find that it is associated with notions of societal regression such as war, terrorism or female oppression. ${ }^{17}$

Discussing the manifold social tensions materialising in the headscarf debate in the introduction, Berghahn and Rostock (2009) assembled in an extensive handbook contributions from cultural research, legal studies, moral philosophy and feminist theory. ${ }^{18}$ Between 2006 and 2009 the international research project VEIL (Values, Equality and Differences in Liberal Democracies) dealt with discourses on the headscarf in different European contexts: debates on veiling, so claimed the authors of the final report, can be considered a focal point in which sociocultural conceptions, as well as national policies concerning religion, gender and minorities materialise. ${ }^{19}$ Similarly, Korteweg and Yurdakul (2016) reconstruct national narratives manifesting in media discussions on veiling in different European countries. In the German case, the authors reason, the headscarf debate engenders a struggle between the political desideratum of a hegemonic culture (Leitkultur) and the ideal of cultural diversity. ${ }^{20}$

Shooman (2014) more generally investigates gendered representations of Muslims in German media discourses in which the headscarf is mobilised as a symbol of female oppression and danger for the shared values of the 'Western' society. ${ }^{21}$ At the same time, she finds the voices of veiled Muslim women marginalised in the discourse, and their status as legitimate and competent speakers constantly challenged. In a recent essay, the sociologists Hark and Villa (2017) take the media coverage of the events at New Year's Eve 2015 in Cologne as a starting point for a intersectional-feminist analysis of the relationship between discourses on Islam and gender discourses. In this context, they reflect on the role of the headscarf in processes of othering, tracing how the veil is signified as a bodily symbol of backwardness in dominant discourses. ${ }^{22}$

Amir-Moazami 2007, 108-9.

16 Amir-Moazami 2014, 84-6.

17 Jäger, Jäger 2007, 127.

18 Berghahn, Rostock 2009. Berghahn presents similar findings in an article from 2017 in which she discusses current developments on the debate.

19 Hadj-Abdou et al. 2012, 199

20 Korteweg, Yurdakul 2016, 218-20.

21 Shooman 2014, 95-7.

22 Hark, Villa 2017, 71. 


\section{The Headscarf in Mainstream Politics}

As the existing research shows, there are primarily two interconnected complexes of ascriptions, which frequently take dominant positions in debates and locate the headscarf and its wearers in opposition to 'European' values (which themselves are re-constructed this way): on the one hand, discourses mobilise the topoi of female oppression and control through the headscarf; on the other hand, there is the narrative of Islamisation, denoting the idea of a gradual replacement of 'Western' institutions and value systems through Islamic ones materialising in the headscarf. The headscarf, I want to argue, is constituted as dangerous in a twofold way: first, it is a danger for the individual wearer, and second, it is a threat for the social order in total. One could say, that a double objectivation takes place: the veil is imbued with allegedly objective meanings that are conceived as true and valued higher than the attributions veiled women make themselves.

Employing current quotations of relevant public speakers in Austria and Germany, I want to show how these positions, one could denote as parts of hegemonic discourses, find expression in the debate. With hegemonic discourses I here refer to those patterns of classification and evaluation which constitute a normative frame for legitimate speech about the headscarf in public discussions. Related elements can be found in diverse social contexts: they are employed by left- and right-wing speakers, ${ }^{23}$ in the feminist discourse, ${ }^{24}$ in nonMuslim migrant milieus or by "secular" Muslims, ${ }^{25}$ in legal disputes ${ }^{26}$ or in (popular) scientific publications. ${ }^{27}$ Not least, such positions inform rhetorics of ruling politicians as well as concrete policies.

\subsection{Oppression and Individual Danger}

A first frequent scheme in debates interprets the headscarf as an instrument of oppression, segregation and disciplination of women in Islam. Such ascriptions - which may have validity in some Muslim milieus, as reports and investigations suggest ${ }^{28}$ - are constituted as a historically constant truth, accurate for all strands of Islam and all forms of veiling. The approval of such statements seems to be wide-

24 Hark, Villa 2017, 77-9.

25 Shooman 2014, 100-2.

26 Barskanmaz 2009.

27 Schröter 2019.

28 Toprak 2012; Wiesinger 2018. 
spread: for the year 2019 a representative survey conducted in Austria showed that $71 \%$ of Austrians agree with the statement that the headscarf is a symbol of female oppression. ${ }^{29}$ Also the federal minister for integration, Susanne Raab from the conservative ÖVP, stated in an interview in the context of discussions about a headscarf ban at public schools as follows:

From my perspective, girls never wear the headscarf voluntarily, there is always force. Either the pressure comes from the family, or from a group. ${ }^{30}$

The same argument, but in a more elaborated way, is brought up by Susanne Schröter, German ethnologist and prominent academic speaker in recent headscarf debates. In a 2019 bestseller book titled Politischer Islam. Stresstest für Deutschland (Political Islam. Stress test for Germany) she states:

The headscarf is burdened by a patriarchal-theological discourse which impinges on girls from Quran schools and mosques, and which forces them with the thread of hellfire to submit to Islamist norms. [...] [This] has to be repelled in schools, and girls must be given the possibility for a carefree development of their personality. ${ }^{31}$

At the same time, subjective perspectives of veiled women are often devaluated: as speakers argue, their religious and cultural position and the resulting 'wrong consciousness', the manipulation by family and peers, or simply fear make it impossible for them to recognise the true and evident meaning of the headscarf, as well as the underlying power structures. ${ }^{32}$ Such an approach mirrors older discourses on the 'Orientals' which emerged in European politics, sciences and popular culture of the 19th century and constructed a dichotomy between the enlightened and rational European on the one hand, and the irrational Oriental, determined by religious emotions, on the other. ${ }^{33}$ Also in the contemporary discourse, veiled Muslim women are denied agency and not recognised as wholesome subjects. They are represented as manipulated, conditioned or even brainwashed. Similar arguments can be found in the liberal-feminist discourse. So for example the German women's rights NGO Terres des Femmes in 2019 started 
a petition demanding a headscarf ban for women younger than 18 in Germany. The campaign's accompanying text says:

The veiling of girls is not a harmless religious covering of the head. It is a gender-specific discrimination and danger for (mental and physical) health. Their chances for equal participation at social life are massively restricted. Early veiling conditions girls to an extent, that they cannot take off the headscarf later anymore. ${ }^{34}$

Similar arguments can be found with Muslim speakers promoting a liberal and secularised Islam: for instance, Seyran Ateş, German lawyer and Imam of a liberal Mosque in Berlin, is a prominent proponent of a modernised Islam rejecting the headscarf as a mere symbol of patriarchy. ${ }^{35}$ Also, Bassam Tibi, scholar of political sciences and muchnoticed expert on Islam in the public debate, makes the same point when he draws a differentiation between an enlightened Euro-Islam and a regressive "headscarf Islam". ${ }^{36}$ However, many empirical studies found evidence that the subjective meanings of the headscarf can vary a lot depending on generation, social position, religious affiliation or ethnic background of the wearer. ${ }^{37}$ This polysemic character is rejected or ignored in dominant discourses. At the same time, differentiations in belief and practice, as well as discursive struggles within the broad and heterogeneous field of "headscarf Islam" are overlooked, while possible negative effects of the headscarf on the psychic health and the development of Muslim women are accentuated. Consequently, legal restrictions on veiling are often legitimised with concerns about the well-being of especially - but not only - minors. Again Raab in an interview from February 2020:

The headscarf among children for me is not a religious symbol, but a sign of oppression and force that comes with early sexualisation. Our concern as government is the protection of girls, because being the minister for women I want to secure that every girl in Austria can unfold freely and autonomously and is not forced to veil. ${ }^{38}$

All of the arguments quoted above hold a similar structure: an ideal of female autonomy marked as European is contrasted with an oppressive and regressive 'outside', while other forms of domination based on patriarchy, racism or socioeconomic marginalisation are not

36 Röther 2016.

37 Klinkhammer 2000; Nökel 2002; Droogsma 2006; Şahin 2014.

38 Baier 2020. 
mentioned. Consequently, a hierarchising demarcation of difference emerges which postulates the need for protection of Muslim women by a Western culture deemed superior in terms of civilisation. ${ }^{39}$ Also here figures from the cultural imaginary of Orientalism are applied, as coercive violence against women is represented as a specifically Islamic cultural problem which can be overcome with Western support and guidance only.

\subsection{Islamisation and Social Danger}

Following the second central line of the dominant discourse, the headscarf not only endangers the individual well-being of its wearers, but also the social order of Western societies in total and consequently the well-being of non-Muslim citizens. In an essentialist manner, veiling is interpreted as a uniform symbol of political Islam, of conservative Islamic legal opinions or of a process of Islamisation. ${ }^{40}$ Consequently, it is framed as contradicting Western principles of liberalism, secularism and gender equality. Such statements are often based on the finding that specific practices of veiling were historically appropriated and promoted by Islamist movements in different ways $^{41}$ and may imply proximity to certain political Muslim groups also in the Western context. ${ }^{42}$ Speakers of the hegemonic discourse, however, tend to absolutise those findings and privilege them at the expense of other layers of meaning. A quotation from Alice Schwarzer puts this in a nutshell:

The subjective motives of girls and women who 'voluntarily' go under a headscarf in democracies [...] are only one level and, by the way, diverse and changing (if these women at all have the freedom to change their opinions). The second level, however, the objective meaning of the veil, is clear: [...] the headscarf is the flag of politicised Islam - and the full-body veil is its total victory. ${ }^{43}$

A central aspect of the Islamisation narrative focuses on the alleged undermining of consensual Western values through the headscarf: the veil here is marked as an symbol of political Islamic groups, an Islamic legal system and a corresponding gender ideology standing in opposition to the 'achievements' of Western culture. The appearance

39 Hark, Villa 2017.

40 Berghahn, Rostock 2009, 12.

41 Almila 2018, 10-11.

42 Şahin 2019, 174-6.

43 Schwarzer 2010, 232 (emphasis in the original). 
of the headscarf in public space and institutions of 'Western' societies thus is interpreted as a kind of infiltration, as part of a process of establishing Islam in historically non-Muslim contexts. ${ }^{44}$ As Alice Weidel, then chairmen of the right-wing AfD, made clear in a speech in 2019 , it is nothing less than freedom which is at stake:

The freedom of European citizens is a precious good which is also threatened by the compulsion to veil of the Islamic shariah. This has to be stopped as early as possible. ${ }^{45}$

In this context, we can see that identity and self-understanding of the non-Muslim dominance society is constantly re-negotiated in such discursive events: by invoking threats, different conceptions of consensual values are steadily actualised. For Weidel it is freedom, Schröter sees democracy threatened, ${ }^{46}$ Raab mentions the rule of law and "constitutional values such as the equality of women and men". ${ }^{47}$ The idea of consensual liberal values, however, becomes blurry, when critique on the headscarf appeals to explicitly anti-liberal thought systems constituting a conservative Christian or an ethnic-national cultural heritage as endangered by veiling. ${ }^{48}$

A more aggressive variant of the Islamisation narrative marks veiled women not only as carriers of 'a flag of Islamism', but considers them instruments in the pursue of a demographic strategy: the conception of Muslim women as oppressed and un-emancipated in some strands of political discourse comes along with the figure of 'fertile' Muslim women who foster Islamisation through childbearing while simultaneously weakening the welfare state through social fraud. ${ }^{49}$ Most prominently, such theories appear in the broadly discussed bestseller books of the German economist Thilo Sarrazin, ${ }^{50}$ until 2020 member of the Social Democratic Party. A quote from an interview in 2009, in which he introduced the pejorative label "headscarf girl" (Kopftuchmädchen) into the German-speaking debate, summarises the position:

The Turks conquer Germany as the Kosovars conquered the Kosovo: with a higher fertility rate. [...] I don't have to accept someone who lives from the state, who rejects the state, who does not care

Shooman 2014, 92.

45 AfD Fraktion im Bundestag 2019.

46 Schwarzer 2019.

47 Marchart 2020.

48 Amir-Moazami 2007, 108-9.

49 Shooman 2014, 97.

50 Sarrazin 2012; 2018; 2020. 
for his children's education and who steadily produces new little headscarf girls. That holds for $70 \%$ of the Turkish and $90 \%$ of the Arab population in Berlin. ${ }^{51}$

Though sharply criticised, Sarrazin insisted on his theses and constantly actualised them in publications and interviews. Similar statements can be found in the rhetoric of mainly right-wing politicians and groups: in 2018, Alice Weidel in a parliamentary speech stated that "headscarf girls" are not able to secure prosperity and the welfare state..$^{52}$ Similarly, the FPÖ and their leading politicians over years produced associations between veiled women, demographic change and welfare fraud in numerous Facebook posts as documented by the Austrian NGO SOS Mitmensch. ${ }^{53}$

\section{Questioning Hegemonies}

At the same time, there are positions in the public discourse who offensively contest hegemonic meanings and try to detach the headscarf from the dominant ascriptions circulating around the themes of oppression or Islamisation. I want to briefly examine three strands here: first, there are voices trying to re-align hijab with Western values. Second, there are positions highlighting the religious meanings, while third, some speakers try to re-signify hijab as a tool of resistance against processes of alienation and objectification fostered by capitalist logics.

\subsection{Hijab as an Expression of Autonomy and Religious Pluralism}

When speakers want to contest dominant statements, inverting their arguments seems to be a common discursive strategy: accordingly, wearing a headscarf should not be regarded as an undermining of female autonomy, but as an expression of it instead. In a liberal society with freedom of religions, accepting women's subjective faithrelated decisions should be of high value. Veiling consequently does not endanger 'Western' values, but is fully aligned with them: wearing a headscarf is constituted a matter of free choice, of freedom of dress and equality of religions in this discourse. In a list of demands published in 2019 by the Islamische Glaubensgemeinschaft in Österreich, the official representation of Muslims living in Austria, the

51 Welt.de 2009.

52 Faz.net 2018.

53 SOS Mitmensch 2019 
committee of Muslim women called for "respect for the right of selfdetermination":

- No prohibition policy on our heads!

- No intrusion into the freedom of religion!

- No discrimination through a Lex Islamica with explicit prohibitions for Muslims!

- 'Protection' must neither lead to paternalism, nor to incapacitation! ${ }^{54}$

In such statements constitutional civil rights are a major point of reference. ${ }^{55}$ In a democratic, liberal and pluralistic society, religious symbols should all be accepted alike, while legal restrictions exclusively targeting Muslim religious practice are understood as illiberal and discriminatory. Speakers attempt at a re-framing of veiling within a broader discursive framework of citizenship and democracy. Leftwing and liberal commentators partly make similar arguments, but also non-Muslim religious agents share the position. In January 2020, the Catholic cardinal and archbishop of Vienna Christoph Schönborn intervened into the ongoing headscarf debate and lobbied against a ban in schools, making a plea for the acceptance of different religious symbols in public space. ${ }^{56}$ Similarly, also the German episcopal conference in 2015 publicly took a stance against bans in public space, framing the headscarf as a matter of confessional freedom. ${ }^{57}$

\subsection{Hijab as a Religious Symbol}

Second, there are speakers who accentuate the religious character of the headscarf and call for an acceptance of explicitly religiously argumentations. In this context, it must be noted that the concrete religious function of the practice of veiling itself is object of discourses within the field of Islam mirroring the vague and ambiguous character of the foundational verses in the Quran. ${ }^{58}$ Research literature points at a broad range of meanings ascribed to the headscarf from a religious perspective: It can be understood as a tool for erecting and maintaining a God-willed gender order, ${ }^{59}$ as a symbol allowing for the recognition of the wearer as Muslim, ${ }^{60}$ or as a 'behaviour check' re-

54 IGGÖ 2019, 4.

55 Amir-Moazami 2007, 130

56 ORF 2020.

57 Kölnische Rundschau 2015.

58 Knieps 1993.

59 Ruby 2006, 58.

60 Droogsma 2007, 302. 
minding the wearer of her religious duties ${ }^{61}$ It can be an expression of submission and obedience to God's will, ${ }^{62}$ or a signal of the wearer's modesty within a community of faith. ${ }^{63}$

In the public discourse, however, the collective and communityrelated religious components are often subordinated to an individualised and subjective religious approach to veiling, centring around spirituality, experiential qualities and an enriching relationship to Allah acquired through the practice. For example, the brochure quoted above defines a self-determined "religious-spiritual approach to the conduct of life" as the central motivation for veiling which is considered to be shared by all headscarf-wearing women. ${ }^{64}$ Also, the German blogger and journalist Merve Kayikci frames the headscarf as a symbol of trust in God in one recent blog entry. ${ }^{65} \mathrm{~A}$ similar instance was given by Carla Amina Baghajati, former spokesperson for Women's affairs in the IGGÖ, when she said that for her "the headscarf means a feeling of security [Geborgenheit] in religion". ${ }^{66}$ Another prominent speaker is the German headscarf-wearing author Kübra Gümüsay who in her 2020 bestseller book Sprache und Sein (Language and Being) investigates everyday processes of linguistic Othering mostly from a Muslim feminist perspective. Criticising the constant pressure on Muslims to explain and rationalise religious practices in secular terms, she passionately pleads for a full acceptance of religious and spiritual approaches to veiling in the public discourse. ${ }^{67}$

Such an approach meets broader trends of the spiritualisation and subjectivation of religious practice, as described by scholars of sociology of religion: The individual quest for spirituality, transcendence and authentic religious experience becomes the central and most accepted religious form in "postmodern" social formations. ${ }^{68}$ Re-framing the wearing of the headscarf as an element of a subjective spiritual endeavour thus can also be read as an alignment of the practice with broader religious discourses centring on experiences and spirituality.

62 Mahmood 2005, 4-5.

63 Abu-Lughod 2005.

64 IGGÖ 2019, 7.

65 Kayikci 2019.

66 ÖIF 2017, 18.

67 Gümüsay 2020, 74-7.

68 Knoblauch 2009, 270-2. 


\subsection{Headscarf as a Symbol of Resistance}

Though marginalised in the public debate, some speakers constitute the hijab as a tool of resistance, opposing dominant ascriptions to femininity and stereotypes about Muslim women. Wearing hijab in this discursive framework is not only a matter of religious freedom, but can actually be source of freedom and emancipation itself, as it liberates women from constraints related to 'Western' ideals of beauty or the commodification of the female body. ${ }^{69}$ Instead, it stresses inner capacities and the dignity of women as persons, and thus has a self-empowering component. One of the most prominent speakers in the German-language discourse is the journalist and declared Muslim feminist Khola Maryam Hübsch, who in her books interprets practices of veiling as a counter-model to alienation fostered by a capitalist system. ${ }^{70}$ Following her argumentation, the wearing of the headscarf encourages an overcoming of egoism, prevents a commodifying gaze on bodies, and helps wearers handling the overabundance of a capitalist society on an individual level. Thus, it can facilitate the experience of real love, prototypically manifesting in a succeeding relationship to God. ${ }^{71}$

Mobilising the headscarf as a symbol for the resistance against Western capitalist hegemony, this discursive strand may have historical predecessors in political struggles in traditionally Islamic societies: In these contexts, veiling often became a resistant act against Western dominance and inferiorisation of non-Western cultural practices. $^{72}$ As the anthropologist Homa Hoodfar argued, it was only its problematisation through "modernising" political forces that constituted the headscarf as a central symbol of Islam. ${ }^{73}$ Also, the more recent cases traced in this paper indicate that Islamic speakers in a Western context constantly have to find strategies to position themselves towards the dominant discourse on veiling.

70 Hübsch 2014, 2018.

71 Hübsch 2014, 13-16.

72 Ahmed 1992, 164.

73 Hoodfar 2001, 423. 


\section{Towards an Intersectional Approach to Veiling?}

Although my findings cannot be considered empirical claims in the strict sense, the fragments discussed so far indicate that in contemporary discourse a dominance of positions critical of the headscarf in terms of media coverage, visibility and public acceptance can be found. Associated with oppression, dis-integration and political Islam, the practice of veiling is constituted as conflicting with a secular legal order and liberal democracy. Being attributed with a 'wrong consciousness', veiled Muslim women themselves are often marginalised in discussions and not taken seriously. These dominant notions, however, are steadily contested from different standpoints: Most likely these contestations utilise 'liberal' arguments emphasising the value of freedom of religion and autonomous choice, but there are also speakers demanding acceptance for religious explanations or raising more general criticism on capitalism.

What is one problematic point about the discourse as a whole, is that only few agents seem willed to stress the openness and contingency of meanings evolving around the hijab. Although speakers of the second fraction address the polysemy of the headscarf at some points, the real variety of concrete practices and meanings attached to them remains invisible in the public discourse. The sociohistoric situated-ness of meanings of veiling within a very diverse field of Muslim beliefs and lifestyles is seldom made explicit in a debate which exhibits the tendency to push its speakers either in a pro- or in a contra-veiling position. Also, veiled women present in the public discourse often act as affiliates of specific religious associations or speak from an educated and privileged standpoint. By focusing on the level of subjective spirituality, other perspectives are made invisible and the multiple realities of Muslim life are hardly represented. Reyhan Şahin aka Dr. Bitch Ray, artist, linguist and author of one of the most extensive scientific studies on veiling practices in Germany, ${ }^{74}$ in a 2018 article and a 2019 book $^{75}$ critically assessed this misrepresentation:

The diversity of different meaning variants stays a taboo this way. [...] [In] a feminist-intersectional sense all women of the Muslim spectrum should be made visible and not only representatives of a certain Islam. [...] All emancipatory processes must become visible, either by conservative Muslims with or without headscarf, by converted Muslims, or veiled Muslims who consciously distance themselves from Islamic associations. [...] Also secular Muslims, 
Alevi, Curds - all those women stay invisible so far. Lacking knowledge [...] regarding Islamic diversity as well as the suspending of a differentiated critique on political Islamic patriarchy [...] promote spaces for generalising critique. $^{76}$

Furthermore, an emancipatory discourse on the headscarf has to acknowledge that the practice of veiling is complex even on an individual level and can never be fully understood by means of underlying gender ideologies, political interests or subjective religious meanings. Instead, it always happens in intersectional environments in which Muslim women have to re-assert their agency towards manifold modes of dominance at the same time. Class domination, ethnic constellations, racist discrimination, religious and political affiliations, generational issues, patriarchal structures of the mainstream society as well as of Muslim communities, and many more structural factors constitute Muslim women's experiential horizons and shape their knowledge as well as the meanings the headscarf has for them. ${ }^{77}$ They are not passive victims but try to take action and make sense of their selves within a multilayered web of structural constraints.

Finally, I suggest that the productions of the German YouTube channel datteltäter ${ }^{78}$ can be regarded a practical implementation of a discourse on the headscarf breaking with the notions discussed in this paper and making visible different modes of dominance: reaching a mostly young audience of millions, the videos of the channel address a variety of problems young Muslim Germans are confronted with in their everyday life in a humoristic way. ${ }^{79}$ The racism and sexism of the dominance society is made visible just as patriarchal structures in Muslim communities and familial milieus, subjective religious motivations are pictured, stereotypes are satirically countered, conflicts of identity and belonging evolving around practices of veiling voiced by actors and actresses with different Muslim backgrounds.

76 Şahin 2017

77 Volpp 2001, 1192.

78 https://www.youtube.com/c/dattelt\%C3\%A4ter.

79 Braun 2019. 


\section{Appendix. Notes on the Performativity of Discursive Knowledge}

Below, I want to briefly share some observations on the conference this volume is the result of and try to contextualise them within the conceptual framework provided so far. In fact, I would argue that the dynamics of the event gave some interesting insights into the reproduction mechanisms of discursive knowledge on the headscarf. Referring to the first afternoon panel, when Karl Prenner, Carla Amina Baghajati and me gave presentations on Muslim practices of veiling, I want to show how (a) the hegemonic discourse was challenged by the speakers and (b) how attendees tried to 'repair' the order of discourse.

Generally, the very organisation of an academic conference on the headscarf points at a certain social need of negotiating this subject. Whether the setting of a conference allows for debate offside hegemonic discourses is an empirical question, depending on the positioning of the organisers and the selection of speakers. In case of the Graz conference, however, none of the speakers of the afternoon panel on Islam was expected to raise perspectives explicitly dismissive of Islam or veiling practices. Strikingly, this panel attracted much more visitors than the others: around 60 people attended the three presentations and the following discussion, at least twice as much as the presentations before. As the conference was open to a general public and advertised in a local newspaper as well as in an adult educational organisation, the audience comprised not only university affiliates, but also other people interested in the subject matter who were mostly of non-Muslim background. Furthermore, one can assume that the current debates on a headscarf ban in schools, as well as the presence of Carla Baghajati, who is a quite prominent speaker in those debates, have triggered additional interest.

\subsection{Challenging Dominant Discourses...}

While Karl Prenner's presentation focused on the Quranic foundations of veiling practices, it was especially Carla Amina Baghajati who rejected dominant ascriptions to the headscarf on several levels in her contribution: first, she framed veiling not as contradicting notions of female autonomy or civil liberties, but as an expression of it instead, in line with the positions I discussed under 5.1. Second, she strived for a historical contextualisation of the current debate within discursive and legislative developments of the last decades. Third, she accentuated the possibility of veiling practices based on subjective religiosity and reflexivity; fourth, she referred to the heterogeneity of the (discursive) field of Islam and expressed her dissent with particular positions. In general, Baghajati performed a subject 
position that may have appeared suspect from the logic of the dominant discourse: trying to break with the image of the oppressed and voiceless headscarf-wearer and with the figure of the threatening Islamist, she both criticised mainstream and conservative-Islamic ascriptions to the veil. Subsequently, my own presentation challenged the dominant discourse in so far as it explicitly addressed the regularity and stereotypy of its statements.

\section{2 ... and Repairing Them}

In the discussion following up the three presentations, almost all of the around ten questions from the audience addressed Carla Baghajati and her talk. Strikingly, the speakers mostly did not refer concretely to her arguments, but rather targeted at making general statements on veiling - one could say, that they tried to restate an attacked discursive order by correcting Baghajati's discourse in performative action. So some attendants stated that the headscarf cannot be discussed without referring to its symbolism in the context of international Islamist movements. Others interpreted the practice of veiling as an expression of dissent with 'Austrian' values of gender equality and secular legal order, even raising the topos of a 'clash of cultures'. Both positions can be interpreted as elements of the Islamisation narrative, framing the headscarf as a danger for the social order of Western societies in general. But also the oppression theme was brought up in a cluster of remarks referring to the current debate in Austria: So speakers stressed the deliberative potential of a headscarf ban in schools for young female Muslims.

Interestingly, many of the statements were made in an emotional way, with some discussants displaying a high level of arousal. This points at an entanglement of discursive knowledge with affective states, implying a bodily attachment of the speakers to abstract notions of secularity or liberalism, ${ }^{80}$ and undermining the discursively constructed dichotomy between the rational European on the one hand, and the emotional Oriental on the other. ${ }^{81}$ Affect here can be interpreted as a productive instance in the sense of Sara Ahmed, as it established relations between agents, created a sense of togetherness and drew boundaries between the 'own' and the Other. ${ }^{82}$ Investing discursive statements with emotional tangibility, affective dynamics in general seem to play a crucial role in the reproduction of discourses. 
In her reaction, Baghajati noted that she sees her work as a superintendent for Islamic religious education in schools exactly in countering coercion and promoting subjective and unconstrained approaches to veiling through pedagogical work. In response, one person from the audience accused Baghajati to consciously obfuscate facts and to transport a biased picture of her work and the Islamic community in Austria as a whole. The few more differentiating comments of the discussion received less attention: so one person pointed at the diversity of Islam, while another stressed the situational character of veiling practices. Their statements, however, did not really affect the overall dynamics of the discussion.

\subsection{Conclusive Remarks}

Given its small scale, one may be tempted now to marginalise the social impact of the conference. Still, it has to be considered that similar discursive 'dramas' with comparable affective dynamics are constantly played out on way bigger stages, e.g. in TV talk shows, parliamentary debates, social media discussions or newspaper columns. The analysed conference was only one exemplar in a sequence of disputes lasting more than twenty years which generate real consequences for the everyday life of Muslim people in German or Austrian context, ranging from legal restrictions, over exclusionary practices, to open violence. Although discursive practices do not necessarily motivate follow-up action, in their reiteration they regularly cause effects reproducing social hierarchies.

\section{Bibliography}

Abu-Lughod, L. (2005). "Modesty Discourses". Suad, J. (ed.), Encyclopedia of Women and Islamic Cultures. Vol. 3, Family, Law and Politics. Leiden; Boston, 494-9.

AfD Fraktion im Bundestag (2019). "Weidel, Kopftuchverbot auch in Deutschland". Mai 20. https://afdbundestag.de/weidel-kopftuchverbot-auch-in-deutschland/.

Ahmed, L. (1992). Women and Gender in Islam. Historical Roots of a Modern Debate. New Haven; London.

Ahmed, S. (2004). "Affective Economies". Social Text, 22(2), 118-39. https:// doi.org/10.1215/01642472-22-2_79-117.

Almila, A.-M. (2018). "Introduction. The Veil across the Globe in Politics, Everyday Life and Fashion". Almila, A.-M.; Inglis, D. (eds), The Routledge International Handbook to Veils and Veiling Practices. London; New York, 1-25.

Amir-Moazami, S. (2007). Politisierte Religion. Der Kopftuchstreit in Deutschland und Frankreich. Bielefeld. 
Amir-Moazami, S. (2014). "The Secular Embodiments of Face-Veil Controversies across Europe". Göle, N. (ed.), Islam and Public Controversy in Europe. Farnham; Burlington, 83-99.

Armenkow, V. (2009). "Der Diskurs um das Kopftuch. Eine Analyse verschiedener Positionen”. Teherani-Krönner, P.; Paulick, S.; Hempel, J. (eds), Die Genderdebatte im Islam aus studentischer Sicht. Freiburg, 133-62.

Aschauer, W. (2019). Einstellungen zu Muslimen in Österreich. Ergebnisse des Sozialen Survey 2018. https://aussda. at/fileadmin/user_upload/p_ aussda/Documents/Einstellung_zu_Muslimen_in_OEsterreich.pdf.

Baier, S. (2020). "'Der politische Islam ist Gift'”. Interview with Susanne Raab. Die Tagespost, 8 February. https://www.die-tagespost.de/politik/ aktuell/Der-politische-Islam-ist-Gift;art315,205230.

Barskanmaz, C. (2009). "Das Kopftuch als das Andere. Eine notwendige postkoloniale Kritik des deutschen Rechtsdiskurses". Berghahn, S.; Rostock, P. (Hrsgg), Der Stoff, aus dem Konflikte sind. Debatten um das Kopftuch in Deutschland, Österreich und der Schweiz. Bielefeld, 365-92.

Berghahn, S.; Rostock, P. (Hrsgg) (2009). Der Stoff, aus dem Konflikte sind. Debatten um das Kopftuch in Deutschland, Österreich und der Schweiz. Bielefeld.

Berghahn, S. (2017). "Die Kopftuchdebatte in Deutschland". Fereidooni, K.; El, M. (Hrsgg), Rassismuskritik und Widerstandsformen. Wiesbaden, 193-212.

Böhmer, C. (2020). "Integrationsministerin, 'Mädchen tragen Kopftuch nie freiwillig'". Interview with Susanne Raab, Kurier Online, 9 January. https://kurier.at/politik/inland/integrationsministerin-maedchen-tragen-kopftuch-nie-freiwillig/400721823.

Braun, L. (2019). "Von Satire-Kalifaten, Bildungsdschihadisten und Hijabista. Muslimische Jugendkulturen im Internet". Oberlechner, M.; Gmainer-Pranzl, F.; Koch, A. (Hrsgg), Religion bildet. Diversität, Pluralität, Säkularität in der Wissensgesellschaft. Baden-Baden, 81-94.

Butler, J. (1997). Excitable Speech. A Politics of the Performative. New York; London.

Diaz-Bone, R. (2010). Kulturwelt, Diskurs und Lebensstil. Eine diskurstheoretische Erweiterung der Bourdieuschen Distinktionstheorie. Wiesbaden.

Droogsma, R. (2007). "Redefining Hijab. American Muslim Women's Standpoints on Veiling". Journal of Applied Communication Research, 35, 294319. https://doi.org/10.1080/00909880701434299.

Evangelisch.de (2019). "Seyran Ateş, Frauen mit Kopftuch tragen das Patriarchat mit". Evangelisch.de, 2 November. https://www.evangelisch. de/inhalte/162048/02-11-2019/seyran-ates-frauen-mit-kopftuch-tragen-das-patriarchat-mit.

Faz.net (2018). "Lieber ,Kopftuchmädel' als ,Bund Deutscher Mädel”. Frankfurter Allgemeine Zeitung Online. 16 May. https://www.faz.net/aktuell/ politik/inland/alice-weidel-provoziert-mit-kopftuchmaedchen-aussage-15593291.html.

Foucault, M. (1978). Dispositive der Macht. Über Sexualität, Wissen und Wahrheit. Berlin.

Foucault, M. (1981). "The Order of Discourse". Young, R. (ed.), Untying the Text. A Post-Structuralist Reader. Boston; London; Benley, 51-78.

Foucault, M. (2004). The Archeology of Knowledge. London.

Gümüsay, K. (2020). Sprache und Sein. Berlin.

Habermas, J. (1990). Moral Consciousness and Communicative Action. Cambridge. 
Hadj-Abdou, L. et al. (2012). "Hijabophobia revisited, Kopftuchdebatten und Politiken in Europa. Ein Überblick über das Forschungsprojekt VEIL". Hausbacher, E. et al. (eds), Migration und Geschlechterverhältnisse. Kann die Migranten sprechen?. Wiesbaden, 198-212.

Hark, S.; Villa, P. (2017). Unterscheiden und herrschen. Ein Essay zu den ambivalenten Verflechtungen von Rassismus, Sexismus und Feminismus in der Gegenwart. Bielefeld.

Hoodfar, H. (2001). "The Veil in Their Minds and on Our Heads, Veiling Practices and Muslim Women". Castelli, E.A. (ed.), Women, Gender, Religion. A Reader. New York, 420-46.

Hübsch, K.M. (2014). Unter dem Schleier die Freiheit. Was der Islam zu einem wirklich emanzipierten Frauenbild beitragen kann. Mannheim.

Hübsch, K.M. (2018). Rebellion der Sehnsucht, Warum ich mir den Glauben nicht nehmen lasse. Freiburg.

IGGÖ (Islamische Glaubensgemeinschaft in Österreich) (2019). Musliminnen am Wort. Wien.

Jäger, M.; Jäger, S. (2007). Deutungskämpfe. Theorie und Praxis Kritischer Diskursanalyse. Wiesbaden.

Kayikci, M. (2019). "Spiritualität wird nur im Yoga-Raum geduldet". Bundeszentrale für politische Bildung, 15 October. https://www.bpb.de/geschichte/deutsche-einheit/mauerfall/294859/spiritualitaet-wird-nur-im-yoga-raum-geduldet.

Keller, R. (2007). "Diskurse und Dispositive analysieren. Die Wissenssoziologische Diskursanalyse als Beitrag zu einer wissensanalytischen Profilierung der Diskursforschung". Forum Qualitative Sozialforschung, 8. https://www.qualitative-research.net/index.php/fqs/article/ view/243 [also Historical Social Research, 33(2008), 73-107].

Klinkhammer, G. (2000). Moderne Formen islamischer Lebensführung. Eine qualitativ-empirische Untersuchung zur Religiosität sunnitisch geprägter Türkinnen der zweiten Generation in Deutschland. Marburg.

Knieps, C. (1993). Geschichte der Verschleierung der Frau im Islam. Würzburg.

Knoblauch, H. (2009). Populäre Religion. Auf dem Weg in eine spirituelle Gesellschaft. Frankfurt am Main; New York.

Kölnische Rundschau (2015). "Bischofskonferenz lobt Kopftuch-Urteil". Rundschau-online.de, 13 March. https://www.rundschau-online. de/news/politik/bundesverfassungsgericht-bischofskonferenz-lobt-kopftuch-urteil-1293848.

Korteweg, A.; Yurdakul, G. (2016). Kopftuchdebatten in Europa. Konflikte um Zugehörigkeit in nationalen Narrativen. Bielefeld.

Marchart, J.M. (2020). "Der , politische Islam' als Unbekannte”. Wiener Zeitung, 29 February. https://www.wienerzeitung. at/nachrichten/politik/oesterreich/2052548-Der-politische-Islam-als-Unbekannte.html.

Mahmood, S. (2005). Politics of Piety. The Islamic Revival and the Feminist Subject. Princeton (NJ); Oxford.

Nökel, S. (2002). Die Töchter der Gastarbeiter und der Islam. Zur Soziologie alltagsweltlicher Anerkennungspolitiken. Eine Fallstudie. Bielefeld.

Oestreich, H. (2004). Der Kopftuch-Streit. Das Abendland und ein Quadratmeter Islam. Frankfurt am Main.

ÖIF (Österreichischer Integrationsfonds) (2017). Perspektiven Integration. Zum Thema Verschleierung im Islam. Wien. 
ORF (2020). "Statt Kopftuchverbot will Schönborn auf Bildung setzen”. Orf.at, 25 January. https://orf.at/stories/3152226.

ORF Wien (2020). "FPÖ will Corona-Wahnsinn stoppen". wien.orf.at, 20 May. https://wien.orf.at/stories/3049678.

Röther, C. (2016). "Bassam Tibi über den Euro-Islam, 'Bejahung der säkulären Demokratie'”. Deutschlandfunk, 1 August. https://www.deutschlandfunk.de/bassam-tibi-ueber-den-euro-islam-bejahung-der-saekulaeren.886.de.html?dram,article_id=361560.

Ruby, T. (2006). "Listening to the Voices of Hijab". Women's Studies International Forum, 29(1), 54-66. https://doi.org/10.1016/j.wsif.2005.10.006.

Şahin, R. (2014). Die Bedeutung des muslimischen Kopftuchs. Eine kleidungssemiotische Untersuchung Kopftuch tragender Musliminnen in der Bundesrepublik Deutschland. Berlin.

Şahin, R. (2017). "Kopftuch und Tabu". taz.de, 20 September 2018. https:// taz.de/Intersektionaler-Feminismus/!5533294.

Şahin, R. (2019). Yalla, Feminismus!. Stuttgart.

Said, E. (2012). Orientalismus. Frankfurt am Main.

Sarrazin, T. (2012). Deutschland schafft sich ab, Wie wir unser Land aufs Spiel setzen. München.

Sarrazin, T. (2018). Feindliche Übernahme, Wie der Islam den Fortschritt behindert und die Gesellschaft bedroht. München.

Sarrazin, T. (2020). Der Staat an seinen Grenzen, Über Wirkung von Einwanderung in Geschichte und Gegenwart. München.

Schieder, R. (2005). "Der Streit um das Kopftuch aus diskursanalytischer Perspektive". Zeitschrift für Evangelische Ethik, 49(1), 9-21. https://doi. org/10.14315/zee-2005-0104.

Schielke-Ziesing, U. (2020). "Islamische Unterdrückung der Frauen". 14 April. Blog entry. https://ulrike.schielke-ziesing.de/aktuelles/2020/04/islamische-unterdrueckung-der-frauen.

Schröter, S. (2019). Politischer Islam. Stresstest für Deutschland. Gütersloh.

Schwarzer, A. (2010). "Für ein Burka-Verbot". Schwarzer, A. (Hrsg.), Die große Verschleierung. Für Integration, gegen Islamismus. Köln.

Schwarzer, A. (2019). "Im Namen einer falschen Toleranz". Zeit Online, 24 July. https://www.zeit.de/2019/31/alice-schwarzer-islam-islamismus-kopftuch-streit.

Shooman, Y. (2014). »... weil ihre Kultur so ist". Narrative des antimuslimischen Rassismus. Bielefeld.

SOS Mitmensch (2019). "Antimuslimischer Rassismus in der österreichischen Politik". Bericht 2018. https://www2.sosmitmensch.at/dl/OMulJKJKNmKJqx4KJK/Bericht2018_Antimuslimischer_Rassismus_in_ der_Politik_SOS_MItmensch.pdf.

Tarlo, E. (2007). "Hijab in London. Metamorphosis, Resonance and Effects". Journal of Material Culture, 12(2), 131-56. https://doi. org/10.1177/1359183507078121.

Terre des Femmes (2019). "Petition DEN KOPF FREI HABEN!". https://www. frauenrechte.de/unsere-arbeit/themen/gleichberechtigung-und-integration/kinderkopftuch.

Toprak, A. (2012). Unsere Ehre ist uns heilig, Muslimische Familien in Deutschland. Freiburg im Breisgau.

Volpp, L. (2001). "Feminism versus Multiculturalism". Columbia Law Review, 101(5), 1181-218. https://doi.org/10.2307/1123774. 
von Scheve, C. (2017). "Emotionen und Affekt im Spannungsfeld von Religion und säkularem Gesellschaftsverständnis". Geschichte der Gefühle. Einblicke in die Forschung. https://www.history-of-emotions.mpg.de/texte/emotionen-und-affekt.

Welt.de (2009). "SPD-Politiker fordert Rücktritt von Thilo Sarrazin". Die Welt Online, 6 October. https://www.welt.de/politik/article4756398/ SPD-Politiker-fordert-Ruecktritt-von-Thilo-Sarrazin.html.

Wiesinger, S. (2018). Kulturkampf im Klassenzimmer. Wie der Islam die Schulen verändert. Bericht einer Lehrerin. Wien. 



\section{Antichistica}

1. Cresci Marrone, Giovannella; Solinas, Patrizia (a cura di) (2013). Microstorie di romanizzazione. Le iscrizioni del sepolcreto rurale di Cerrione. Storia ed epigrafia 1.

2. Tonietti, Maria Vittoria (2013). Aspetti del sistema preposizionale dell'eblaita. Studi orientali 1.

3. Caloi, Ilaria (2013). Festòs protopalaziale. Il quartiere ad ovest del Piazzale I. Strutture e ritrovamenti delle terrazze mediana e superiore. Archeologia 1.

4. De Vido, Stefania (a cura di) (2014). Poteri e legittimità nel mondo antico. Da Nanterre a Venezia in memoria di Pierre Carlier. Storia ed epigrafia 2.

5. Carpinato, Caterina (a cura di) (2014). Storia e storie della lingua greca. Filologia e letteratura 1.

6. Ciampini, Emanuele Marcello; Zanovello, Paola (a cura di) (2015). Antichità egizie e Italia. Prospettive di ricerca e indagini sul campo. Atti del III Convegno Nazionale Veneto di Egittologia "Ricerche sull'antico Egitto in Italia". Studi orientali 2.

7. Ciampini, Emanuele Marcello; Rohr Vio, Francesca (a cura di) (2015). La lupa sul Nilo. Gaio Cornelio Gallo tra Roma e l'Egitto. Storia ed epigrafia 3.

8. Ermidoro, Stefania (2015). Commensality and Ceremonial Meals in the Neo-Assyrian Period. Studi orientali 3.

9. Viano, Maurizio (2016). The Reception of Sumerian Literature in the Western Periphery. Studi orientali 4.

10. Baldacci, Giorgia (2017). L'edificio protopalaziale dell'Acropoli Mediana di Festòs (Vani CV-CVII). Archeologia 2.

11. Crippa, Sabina; Ciampini, Emanuele Marcello (eds) (2017). Languages, Objects, and the Transmission of Rituals. An Interdisciplinary Analysis On Some Unsearched Ritual Practices in the Graeco-Egyptian Papyri (PGM). Storia ed epigrafia 4.

12. Scarpa, Erica (2017). The City of Ebla. A Complete Bibliography of Its Archaeological and Textual Remains. Studi orientali 5.

13. Pontani, Filippomaria (ed.) (2017). Certissima signa. A Venice Conference on Greek and Latin Astronomical Texts. Filologia e letteratura 2.

14. Mastandrea, Paolo (a cura di) (2017). Strumenti digitali e collaborativi per le Scienze dell'Antichità. Filologia e letteratura 3.

Per acquistare | To purchase:

https://fondazionecafoscari.storeden.com/shop 
15. Caldelli, Maria Letizia; Cébeillac-Gervasoni, Mireille; Laubry, Nicolas; Manzini, Ilaria; Marchesini, Raffaella; Marini Recchia, Filippo; Zevi, Fausto (a cura di) (2018). Epigrafia ostiense dopo il CIL. 2000 iscrizioni funerarie. Storia ed epigrafia 5.

16. Corò, Paola (2018). Seleucid Tablets from Uruk in the British Museum. Studi orientali 6.

17. Marcato, Enrico (2018). Personal Names in the Aramaic Inscriptions of Hatra. Studi orientali 7 .

18. Spinazzi-Lucchesi, Chiara (2018). The Unwound Yarn. Birth and Development of Textile Tools Between Levant and Egypt. Studi orientali 8.

19. Sperti, Luigi; Tirelli, Margherita; Cipriano, Silvia (a cura di) (2018). Prima dello scavo. Il survey 2012 ad Altino. Archeologia 3.

20. Carinci, Filippo Maria; Cavalli, Edoardo (a cura di) (2019). Élites e cultura. Seminari del Dottorato in Storia Antica e Archeologia. Archeologia 4.

21. Mascardi, Marta; Tirelli, Margherita (a cura di) (2019). L'anima delle cose. Riti e corredi dalla necropoli romana di Opitergium. Archeologia 5.

22. Valentini, Alessandra (2019). Agrippina Maggiore. Una matrona nella politica della 'domus Augusta'. Storia ed epigrafia 6.

23. Cresci Marrone, Giovannella; Gambacurta, Giovanna; Marinetti, Anna (a cura di) (2020). Il dono di Altino. Scritti di Archeologia in onore di Margherita Tirelli. Archeologia 6.

24. Calvelli, Lorenzo; Cresci Marrone, Giovannella; Buonopane, Alfredo (a cura di) (2020). 'Altera pars laboris'. Studi sulla tradizione manoscritta delle iscrizioni antiche. Storia ed epigrafia 7.

25. Calvelli, Lorenzo (a cura di). La falsificazione epigrafica. Questioni di metodo e casi di studio. Storia ed epigrafia 8.

26. Maidman, Maynard P. (2020). Life in Nuzi's Suburbs. Text Editions from Private Archives (JEN 834-881). Studi orientali 9.

27. Maiocchi, Massimo; Visicato, Giuseppe (2020). Administration at Girsu in Gudea's Time. Studi orientali 10.

28. Petrantoni, Giuseppe (2021). Corpus of Nabataean Aramaic-Greek Inscriptions. Studi orientali 11.

29. Traviglia, Arianna; Milano, Lucio; Tonghini, Cristina; Giovanelli, Riccardo (eds) (2021). Stolen Heritage. Multidisciplinary Perspectives on Illicit Trafficking of Cultural Heritage in the EU and the MENA Region. Archeologia 7. 

This volume - which stems from an international conference held at the University of Graz on March 2, 2020, just before the outbreak or the COVID-19 pandemic - represents a small, but specifically targeted contribution to a field of research and discussion that has increasingly come to the fore in the last two decades, regarding the practice of covering or veiling womens' heads or faces over different times and places. "Dress is never value free", as anthropologists state, and veiling functions as an assertion/communication of relationship dynamics in terms of gender, social and cultural identity, phases and stages of life (puberty, marriage, death) or of religious beliefs - even reaching to a typical dichotomy of our times, the female condition between tradition and modernity.

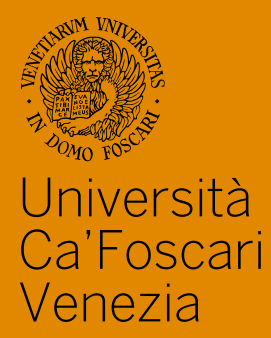

